\title{
International Capital Markets
}

\section{Developments and Prospects}

By a Staff Team from the Exchange and Trade Relations and Research Departments 


\title{
International Capital Markets \\ Developments and Prospects
}

By a Staff Team from the Exchange and

Trade Relations and Research Departments

\author{
Alessandro Leipold \\ Donald Mathieson \\ Mohamed El-Erian \\ David Folkerts-Landau \\ John Clark \\ Augusto de la Torre \\ Juan Carlos Di Tata \\ Steven Fries \\ Liliana Rojas-Suarez \\ Louis Pauly
}

INTERNATIONAL MONETARY FUND

Washington, DC

MAY 1991 
(C) 1991 International Monetary Fund

ISBN 1-55775-218-4

ISSN 0258-7440

Price: US\$20.00

(US\$12.00 to full-time faculty members and students at universities and colleges)

Please send orders to:

International Monetary Fund, Publication Services 700 19th Street, N.W., Washington, D.C. 20431, U.S.A.

Tel. (202) 623-7430 Telefax: (202) 623-7201 


\section{Contents}

Page

Preface $\underline{\text { vii }}$

I. Overview of Developments and Key Issues

Financial Market Trends

Major Market Developments

Spontaneous Financing for Developing Countries

Recent Structural Changes in Financial Markets

Financial Policy Issues

"Financial Fragility" 10

Global Credit Pressures $\quad \frac{11}{12}$

Market Re-Entry of Developing Countries 12

Public Policy Response to Strains in the
Financial System

Reassessing Official Safety Nets 14

Emphasizing Capital Strength

Supervising Financial Conglomerates $\quad \underline{17}$

II. Recent Developments in International Capital Markets $\quad \mathbf{1 8}$

Macroeconomic Environment 18

Impact of the Middle East Crisis $\quad \frac{18}{18}$

Market Conditions at the Beginning of the Crisis 20

Initial Asset Price Effects 20

Effects on Institutions and Markets 23

Impact of the Outbreak of Hostilities

Net International Capital Flows

United States 27

Japan 27

Germany 27

Gross International Financial Flows $2 \frac{28}{23}$

Markets for Derivative Products

III. Recent Developments in the Regulation and Supervision

of Financial Markets $\quad \mathbf{3 5}$

International Capital Adequacy Standards

Capital Adequacy Requirements for Market Risks
Assumed by Banks

Issues in Monitoring Large Credit Exposures

Supervision of Financial Conglomerates $\quad 40$

Recent Initiatives Against Money Laundering $\underline{42}$

IV. Key Issues in Official Safety Nets and International

Financial Markets

44

Rationale for Official Safety Nets $\underline{44}$

Key Components of Official Safety Nets in Major

Financial Systems

Sources of Official Assistance and Guarantees

Measures to Limit Official Credit Risks

Economic Effects of Official Safety Nets

Proposals for the Reform of the U.S. Official Safety Net 


\begin{tabular}{ll} 
V. Spontaneous Capital Market Financing for Developing \\
Countries \\
Historical Background \\
Recent Developments \\
Bank Lending \\
Portfolio Flows \\
Re-Entry to Capital Markets: Addressing Investor \\
$\quad$ Concerns & $\underline{\underline{60}}$ \\
Counterparty Credit Risk and Country Transfer Risk & $\underline{\underline{62}}$ \\
Liquidity Risks and Transaction Costs & $\underline{68}$ \\
Facilitating Market Re-Entry & $\underline{\underline{68}}$ \\
\hline
\end{tabular}

VI. Bank Debt Restructurings and Secondary Market

Developments

Bank Debt Restructurings

Recent Financing Packages

Debt Conversion Programs

$\underline{60}$

$\frac{60}{62}$

$\frac{62}{62}$

$\underline{64}$

Developments in the Secondary Market for Claims on Developing Countries

Box 1 Key Components of the Safety Net

Box 2 U.S. Treasury Recommendations

Statistical Appendix

\section{Tables}

I. 1. Selected Economic Indicators, 1983-90

2. Summary Balance of Payments of Major Industrial Countries

3. International Lending, 1983-Third Quarter 1990

II. 4. Change in Cross-Border Bank Claims and Liabilities, 1984-Third Quarter 1990

5. Developments in International Bond Markets, 1983-90

6. Equity Markets: Secondary Trading Values and Volumes, 1979-89

7. International Equity Markets-Primary Issuance, 1986-89

III. 8. Status of Selected EC Financial Directives

V. 9. Structure of Developing Country Long-Term Debt

10. Long-Term Bank Credit Commitments to Developing Countries, 1984-90

11. Developing Countries: Terms on Syndicated Bank Credits, 1988-90

12. International Bond Issues by Developing Country Borrowers, 1984-90

\section{$\underline{64}$}

13. Average Terms on International Bond Issues by Selected Developing Country Borrowers

VI. 14. Chronology of Bank Debt Restructurings and Bank Financial Packages, 1984-March 1991

15. Impact of Debt and Debt-Service Reduction Packages

16. Debt Conversions, 1985-90 


\section{Appendix}

A1. Long-Term and Short-Term Interest Rate Differentials Between the United States and Other Major Countries, 1987-90

A2. Volatility of Major Stock Prices, First Quarter 1987-Fourth Quarter 1990

A3. Stock Market Indices and Interest Rates, August 1-20, 1990

A4. United States: Balance of Payments, 1987-Third Quarter 1990

A5. Japan: Balance of Payments, 1987-Third Quarter 1990

A6. Germany: Balance of Payments, 1987-Third Quarter 1990

A7. United Kingdom: Balance of Payments, 1987--Third Quarter 1990

A8. Change in Interbank Claims and Liabilities, 1984-Third Quarter 1990

A9. Change in Claims on Nonbanks and Liabilities to Nonbanks, 1984-Third Quarter 1990

A 10. Change in Cross-Border Bank Claims on and Liabilities to Developing Countries, by Region, 1984-Third Quarter 1990

A11. Concerted Lending: Commitments and Disbursements, 1985-90

A12. U.S. Banks, Developing Country Claims Relative to Capital, 1984-Third Quarter 1990

A13. External Assets of BIS Reporting Banks by Maturity and Undisbursed Credit Commitments, December 1985-December 1989

A14. Gross International Bond Issues and Placements by Groups of Borrowers, 1985-90

A15. Early Repayments of International Bonds, 1985-90

$\underline{102}$

A 16. Market for Equity-Related Bonds, 1985-90

A17. Market for Fixed Rate Bonds, 1985-90

A 18. Market for Floating Rate Issues, 1985-90

A 19. Borrowing on International Markets by Major Instruments, 1985-90

A20. Gross International Equity Flows, 1986--First Quarter 1990

A21. Net International Equity Flows, 1986-First Quarter 1990

A22. Destination of Cross-Border Mergers and Acquisitions, 1986-First Half 1990

A23. Financial Futures and Options: Exchanges, Contracts, and Volume of Contracts Traded, 1987-90

A24. Outstanding Swap Transactions by Currencies, 1987-89

A25. Capital/Asset Ratios of Banks in Selected Industrial Countries, 1980-89

A26. Long-Term Bank Credit Commitments, 1984-90

A27. Bank Credit Commitments by Country of Destination, 1984-90

A28. Terms of Long-Term Bank Credit Commitments, 1984-90

A29. International Bond Issues by Selected Developing Country Borrowers, 1989-90

A30. Amounts of Medium- and Long-Term Bank Debt Restructured, 1984-90

A31. Debt and Debt-Service Reduction in Commercial Bank Agreements, 1987-March 1991 
A32. Terms of Selected Bank Debt Restructurings and Financial Packages, 1984-1990

A33. Terms and Conditions of Bank Debt Restructurings and Financial Packages, 1989-March 1991

A34. Financing Instruments and Options in New Money Packages and Restructurings of Bank Debt for Selected Developing Countries, 1984-1990

A35. Features of Selected Debt Conversion Schemes

\section{Charts}

I 1. Five Major Industrial Countries' Nominal Interest Rates 1983-90

2. International Bond Issues by Major Instruments, 1985-90

3. Oil and Gold Prices, July 6, 1990-January 25, 1991

4. Secondary Market Prices for Developing Country Loans

II. 5. Major Industrial Countries: Stock Market Indices, January 1, 1989-January 31, 1991

6. Impact of the Oil Price Rise on Developing Country Stock Markets

7. Major Industrial Countries: Interest Rates, July 1January 31, 1991

8. Interest Rates Implied by Futures Contracts and Spot Rates for U.S. Treasury Bills, Notes, and Bonds

9. Implied Volatility of Various Asset Prices, July 5, 1990January 28, 1991

10. Growth Rate of International Bank Claims, 1980-Third Quarter 1990

11. International Bond Issues by Groups of Borrowers, 1985-90

12. Currency Composition of International Bond Issues, 1985-90

V. 13. Terms on International Bank Lending Commitments, 1979-90

14. Yield on Selected Debt Instruments, 1987-First Quarter 1991

The following symbols have been used throughout this paper:

... to indicate that data are not available:

- to indicate that the figure is zero or less than half the final digit shown, or that the item does not exist:

- between years or months (e.g., 1990-91 or January-June) to indicate the years or months covered, including the beginning and ending years or months:

/ between years (e.g., 1990/91) to indicate a crop or fiscal (financial) year.

"Billion" means a thousand million.

Minor discrepancies between constituent figures and totals are due to rounding.

The term "country" used in this study does not in all cases refer to a territorial entity that is a state as understood by international law and practice. The term also covers some territorial entities that are not states, but for which statistical data are maintained and provided internationally on a separate and independent basis. 


\section{Preface}

This study was prepared under the direction of Alessandro Leipold, Advisor in the Exchange and Trade Relations Department of the International Monetary Fund, with Donald Mathieson, Chief of the Financial Studies Division of the Research Department. The co-authors, staff members from both departments, are listed on the title page.

Background for the study was provided in part by informal discussions with commercial and investment banks, securities houses, stock and futures exchanges, regulatory and monetary authorities, and the staffs of the Bank for International Settlements, the Commission of the European Communities, the Organization for Economic Cooperation and Development, the World Bank, the International Finance Corporation, and the Japan Center for International Finance. The discussions took place in Amsterdam, Basle, Bonn, Brussels, Frankfurt, Hong Kong, London, New York, Ottawa, Paris, Tokyo, Toronto, Washington, and Zurich at various times between September and early December 1990.

In addition to the authors, other Fund staff members taking part in some of the discussions or making contributions to the study at various stages included C. Maxwell Watson and Charles Collyns (of the Exchange and Trade Relations Department). Staff of the Bureau of Statistics, particularly Richard Stillson and Robert Di Calogero, developed and compiled the data based on the Fund's international banking statistics. Research assistance was provided by Can Demir and Rosa Vera-Bunge. Louis Pauly prepared the text for publication. Delrene Alvis, Gail Campbell, Sheila O'Connor, Margaret Tan, and Nora Whitehouse patiently typed and retyped the text and tables. Juanita Roushdy, of the External Relations Department, gave the manuscript a final edit and efficiently coordinated the production.

The study benefited from comments by staff in other departments of the Fund and by members of the Executive Board. Opinions expressed, however, are those of the authors and do not necessarily represent the views of the Fund or of the Executive Directors. Similar studies on international capital markets have been prepared in recent years; the previous study was published in April 1990 in the World Economic and Financial Surveys series. The present study was completed in February 1991 and reflects developments to that time.

The country classification used throughout this report is that of the October 1990 World Economic Outlook. In particular, the developing country category does not include certain Eastern European (Bulgaria, Czechoslovakia), African (Angola, Namibia), and Asian (Mongolia) countries nor the U.S.S.R. A new country classification is set out in the May 1991 World Economic Outlook. 


\section{Overview of Developments and Key Issues}

T his report presents the annual survey of international capital market developments and prospects. It summarizes recent developments in capital market flows and asset prices, including the initial impact of the Middle East crisis, and reviews the main ongoing structural changes in financial markets. Against this background, the study examines three key issues that emerge from recent developments. These are, first, indications of "financial fragility" in a number of industrial countries; second, concerns about a shortage of global savings relative to prospective investment demands; and third, recent developments with regard to spontaneous capital market financing for developing countries and the process of market re-entry by some countries with recent debt-servicing difficulties. The study also considers public policy responses to financial strains, in particular, attempts by authorities to ensure systemic safety and soundness and to maintain the cost effectiveness of official safety nets as the process of financial market liberalization and innovation continues.

\section{Financial Market Trends}

International capital market conditions changed significantly between 1989 and 1990 , shifting from buoyant activity against a relatively stable macroeconomic background to retrenchment in the face of a more unsettled situation. Heightened uncertainty, including increased concerns about inflation as well as recession, was reflected in a sharp contraction of capital market activity, greater asset price variability, and increased demand for safe and liquid assets. Over this period, the markets were influenced by major political events, including German unification, the opening up of Eastern Europe, and turmoil in the Middle East, and by more specific factors, such as the weakening of equity and real estate prices in a number of countries. In these more difficult circumstances, international financial markets again demonstrated an overall resilience, as they did in the wake of the October 1987 equity market break. The underlying market structures that emerged from the liberalization and integration processes of the 1980s have, however, yet to be fully tested in an economic recession. By the end of the period under review, the economic downturn in a number of countries brought to the forefront concerns about the fragility of those markets and of financial institutions operating within them.

After several years of rapid expansion in the world economy, economic growth generally slowed across the major industrial countries in 1989-90 (Table 1). There were, however, marked differences in relative performances, with growth in the United States, Canada, and the United Kingdom slowing considerably, while remaining comparatively strong in Japan and Germany and other European countries. Current account imbalances of the three largest industrial countries narrowed appreciably (Table 2). But, with rates of capacity utilization remaining relatively high and energy prices rising in 1990, there was renewed concern about inflationary pressure. In view of such concern, and an anticipated expansion in the demand for funds associated with structural reforms in Eastern Europe and the newly unified Germany, real interest rates in several industrial countries rose significantly during 1990 , most notably at the long end of the maturity spectrum, and have remained generally high, despite some recent declines. Movements were mixed, however, with trends differing among major countries; by the spring of 1990 - for the first time since the early $1970 \mathrm{~s}$-long-term nominal interest rates in the United States and in Germany were at comparable levels, and the U.S. dollar subsequently weakened against the deutsche mark to its lowest level in the postwar period, from which it recovered sharply however in the wake of the Middle East conflict. Long-term rates in Japan also increased appreciably since early 1989. By the end of 1990 , these movements had brought about a significant reversal in interest rate differentials, with U.S. short- and long-term rates having fallen below the average for the major industrial countries (Chart 1).

\section{Major Market Developments}

Against the macroeconomic backdrop sketched above, international capital markets were generally characterized in 1990 by an increased cost of funds, as both interest rates and risk premiums rose and lending margins widened. Prices in most equity markets, both in industrial and developing countries (with the notable exceptions of Chile, Colombia, 
Table 1. Selected Economic Indicators, 1983-90

(In billions of U.S. dollars; or in percent)

\begin{tabular}{|c|c|c|c|c|c|c|c|c|}
\hline & 1983 & 1984 & 1985 & 1986 & 1987 & 1988 & 1989 & 1990 \\
\hline Total of current account deficits' & 152 & 184 & 209 & 260 & 256 & 267 & 273 & 285 \\
\hline \multicolumn{9}{|l|}{ Of which: } \\
\hline Seven major & 44 & 102 & 128 & 153 & 182 & 174 & 170 & 163 \\
\hline Developing countries & 89 & 66 & 61 & 83 & 54 & 67 & 62 & 69 \\
\hline \multicolumn{9}{|l|}{$\begin{array}{l}\text { Total of fiscal balances for seven major industrial } \\
\text { countries }\end{array}$} \\
\hline Central government & -355 & -341 & -364 & -404 & -358 & -321 & -296 & -362 \\
\hline General government & -288 & -242 & -252 & -292 & -233 & -180 & -121 & -204 \\
\hline $\begin{array}{l}\text { Overall current account balances of developing } \\
\text { countries }^{2}\end{array}$ & -57 & -26 & -23 & -43 & - & -16 & -15 & -10 \\
\hline $\begin{array}{l}\text { Reserve accumulation of developing countries } \\
(\text { accumulation }+)\end{array}$ & 2.2 & 10.3 & 16.9 & 2.1 & 54.5 & 0.5 & 20.7 & 34.1 \\
\hline Growth rate in value of world trade & -2.4 & 5.8 & 0.4 & 9.7 & 17.4 & 14.5 & 8.2 & 13.4 \\
\hline Growth rate of real GNP of industrial countries & 2.6 & 4.8 & 3.4 & 2.7 & 3.3 & 4.5 & 3.3 & 2.6 \\
\hline Inflation rate of industrial countries (GNP deflators) & 5.2 & 4.5 & 3.7 & 3.4 & 3.0 & 3.3 & 4.0 & 4.1 \\
\hline Interest rates (six-month Eurodollar deposit rate) ${ }^{3}$ & 9.9 & 11.3 & 8.6 & 6.8 & 7.3 & 8.1 & 9.3 & 8.4 \\
\hline
\end{tabular}

Mexico, and Venezuela) declined sharply and some earlier sources of low-cost funding dried up (e.g., bonds with equity warrants $\left.{ }^{1}\right)$. In such an environment, there was a shift to shorter-term, more liquid, and relatively lower-risk instruments. Market participants characterized the process as a "flight to quality," with lower-rated borrowers facing greater difficulty in raising needed financing, widening spreads between higher and lower quality instruments, and intensified concerns about a possible "credit crunch."

During the year, major market segments witnessed a marked decline in activity. New issues on international bond markets fell by 11 percent, from $\$ 256$ billion in 1989 to $\$ 229$ billion in 1990 . The decline was due largely to a sharp contraction in issues of equity warrant bonds by Japanese corporations, a reflection of weakness in the Tokyo stock market. In contrast, floating rate note issuance expanded in the face of increased interest rate uncertainty, as did that of ECU (European currency unit) bonds, sustained by an increasing range of actively traded bonds issued by European govern-

\footnotetext{
' Equity warrants provide holders the right to buy stock in a company at a fixed price. When expectations were for continued increases in stock prices (as in 1989), borrowers-notably Japanese corporations-were able to issue equity warrant bonds with very low coupons.
}

ments and agencies (Chart 2). Meanwhile, crossborder bank lending declined by 25 percent from $\$ 581$ billion in the first three quarters of 1989 to $\$ 432$ billion in the corresponding period of 1990 , essentially reflecting a sharp slowdown in interbank business (Table 3 ).$^{2}$ In particular, interbank lending by U.S. and Japanese banks showed an increase of only $\$ 42$ billion in the first three quarters of 1990 , compared with an expansion of $\$ 127$ billion in the corresponding period of 1989. This retrenchment reflects in part efforts by banks in these countries to restrain asset growth as they attempt to conform to internationally agreed capital adequacy standards. In contrast, as borrowers and lenders sought ways to manage increased risk and uncertainty in an unsettled environment, the markets for financial futures and options continued the strong expansion that was evident throughout the 1980s. Trading volumes, the range of contracts offered, and the degree of competition among organized futures and options exchanges around the world all increased markedly.

The unwinding in 1990 of the asset price inflation associated with earlier sustained bank lending in a number of countries (real estate prices in the United

\footnotetext{
${ }^{2}$ More generally, it may be noted that international banking flows have become more volatile in recent years, with apparent seasonal patterns in the major aggregates being replaced by less regular but substantially larger quarterly fluctuations.
} 
Table 2. Summary Balance of Payments of Major Industrial Countries

(In billions of U.S, dollars)

\begin{tabular}{|c|c|c|c|c|c|c|c|c|}
\hline & \multirow{2}{*}{$\begin{array}{l}\text { Current } \\
\text { Account } \\
\text { Balance }\end{array}$} & \multirow{2}{*}{$\begin{array}{l}\text { Net Direct } \\
\text { Investment }\end{array}$} & \multicolumn{2}{|c|}{$\begin{array}{l}\text { Portfolio } \\
\text { Investment }\end{array}$} & \multirow{2}{*}{$\begin{array}{l}\text { Bank } \\
\text { Flows }\end{array}$} & \multirow[b]{2}{*}{ Other } & \multirow{2}{*}{$\begin{array}{c}\text { Changes } \\
\text { in } \\
\text { Reserves }{ }^{\prime} \\
(+ \text { increase })\end{array}$} & \multirow{2}{*}{$\begin{array}{l}\text { Errors } \\
\text { and } \\
\text { Omissions }\end{array}$} \\
\hline & & & Bonds & Equities & & & & \\
\hline \multicolumn{9}{|l|}{ United States } \\
\hline 1988 & -129.0 & 42.2 & 41.7 & -1.4 & 16.1 & 2.5 & 36.3 & -8.3 \\
\hline 1989 & -110.0 & 40.5 & 54.9 & -10.1 & 8.2 & 10.8 & -16.8 & 22.6 \\
\hline Three quarters 1990 & -69.0 & -17.4 & -1.9 & -15.7 & 27.0 & 14.1 & 8.9 & 53.7 \\
\hline \multicolumn{9}{|l|}{ Japan } \\
\hline 1988 & 79.6 & -34.7 & -56.6 & 3.8 & 38.4 & -17.1 & -16.5 & 3.1 \\
\hline 1989 & 57.0 & -45.2 & -21.6 & -10.9 & 3.7 & 26.1 & 12.8 & -21.8 \\
\hline First half 1990 & 20.2 & -25.7 & 1.3 & -18.0 & -14.0 & 30.8 & 9.8 & -4.4 \\
\hline \multicolumn{9}{|l|}{ Germany } \\
\hline 1988 & 50.5 & -9.9 & -36.4 & -7.3 & -2.8 & -14.9 & 18.4 & 2.4 \\
\hline 1989 & 55.4 & -7.7 & -12.1 & 7.6 & -25.0 & -32.1 & 10.6 & 3.0 \\
\hline Three quarters 1990 & 36.0 & -11.6 & -15.8 & -1.7 & -2.2 & -15.9 & -2.4 & 14.0 \\
\hline \multicolumn{9}{|l|}{ United Kingdom } \\
\hline 1988 & -27.3 & -20.5 & 3.0 & 3.6 & 18.5 & 6.9 & 1.9 & 14.0 \\
\hline 1989 & -32.1 & -1.8 & -15.5 & -24.3 & 20.4 & 11.4 & 16.2 & 25.7 \\
\hline Three quarters 1990 & -24.4 & 11.8 & -6.3 & 8.7 & -14.5 & 0.1 & 6.6 & 17.8 \\
\hline \multicolumn{9}{|l|}{ France } \\
\hline 1988 & -3.5 & -6.0 & 6.8 & 0.9 & 3.8 & -3.1 & 0.1 & 0.9 \\
\hline 1989 & -3.8 & -9.1 & 16.8 & 5.6 & 5.2 & -15.2 & 2.5 & -1.9 \\
\hline First half 1990 & -4.3 & -14.1 & 8.6 & 3.2 & 33.3 & -16.7 & -6.0 & -4.3 \\
\hline \multicolumn{9}{|l|}{ Canada } \\
\hline 1988 & -8.2 & -2.3 & 12.9 & -2.8 & 3.2 & 8.2 & -7.6 & -3.4 \\
\hline 1989 & -14.1 & -1.0 & 13.1 & 2.6 & -0.7 & 4.9 & -0.3 & -4.6 \\
\hline Three quarters 1990 & -10.7 & 1.1 & 7.2 & -0.4 & 5.3 & 2.1 & -0.7 & -3.8 \\
\hline \multicolumn{9}{|l|}{ Italy } \\
\hline 1988 & -6.2 & 1.3 & 0.4 & - & 8.0 & 4.0 & -7.5 & - \\
\hline 1989 & -10.6 & 0.5 & 3.3 & - & 11.1 & 11.5 & -11.1 & -4.6 \\
\hline
\end{tabular}

Kingdom and the United States; equity, and possibly also property, prices in Japan) and the effects of high corporate debt leverage placed increasing strains on banks' balance sheets. This was evidenced in deteriorating asset quality, higher provisioning against bad loans, and lower profitability. In some countries, the economic downturn that began during the year intensified these strains and brought to the fore concerns about "financial fragility."

In addition, during 1990, net capital flows shifted among major industrial countries, the interpretation of which is complicated by a concomitant increase in quite large errors and omissions items. The main developments in this regard were as follows,

(1) A reversal of the traditional net portfolio and foreign direct investment inflows to the United States; net foreign purchases of U.S. Treasury bonds, in particular, declined sharply. The reduced external financing from these sources was associated with a lower current account deficit and an increase in the positive errors and omissions item.

(2) A sharp fall in net investment in foreign securities by Japanese institutions in 1990 (involving, inter alia, the first sustained net sales of U.S. securities since 1982), in the face of narrowing interest rate differentials and, in some cases, the need to cover losses stemming from the fall in the Japanese stock market. In contrast, the importance of net direct investment outflows as a counterpart to the current account surplus began increasing as from 1989.

(3) Sustained net portfolio outflows from Germany through most of 1990 , possibly reflecting the increased uncertainty associated with the unification process, with nonresident interest in the substantial amounts of government bonds issued appearing only toward the end of the year. Direct investment outflows from Germany also increased 


\section{Chart 1. Five Major Industrial Countries' Nominal Interest Rates, 1983-90 \\ (In percent)}

16

Short-Term ${ }^{1}$

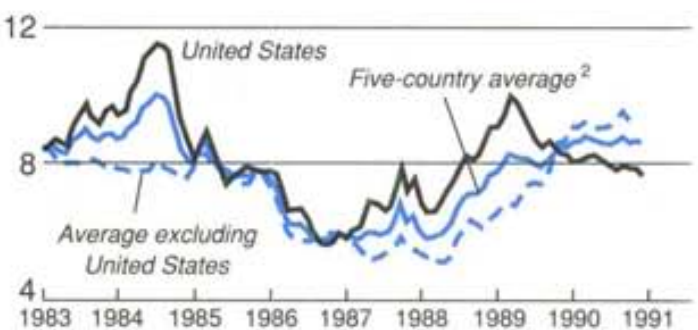

$$
16
$$

\section{Long-Term ${ }^{3}$}

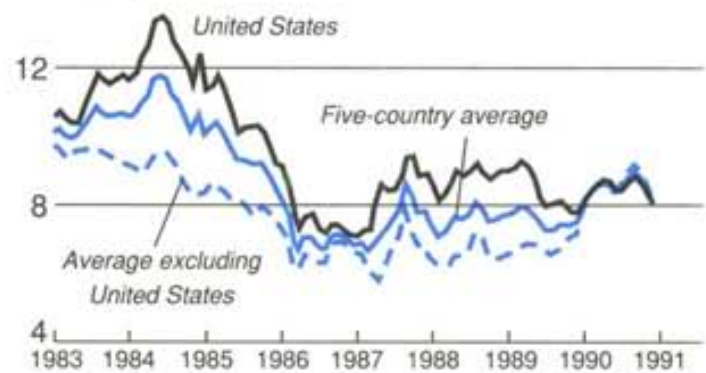

Sources: Banque de France: Nikkei Data Service; Bank of England; Data Rexources Inc. (DRI): U.S. Federal Reserve; and International Monetary Fund. Treasurer's Department.

'Monthly averages of daily rates on money market instruments of about 90 days' maturity.

France, Germany, Japan, the United Kingdom, and the United States; using three-year moving average, GNP-based weights.

'Monthly averages of daily or weekly yields on government bonds, with maturities ranging from 7 years for Japan to 20 years for the United Kingdom and the United States.

significantly, with European Community (EC) countries being the main recipients, while the share taken by the United States fell sharply.

For developing countries, access to spontaneous credit on international capital markets continued to be limited in 1989-90, with few exceptions. A significant development was the incipient return to the capital markets-and particularly the bond markets-of some Latin American borrowers. The countries of Eastern Europe, for their part, saw their recourse to the bond and syndicated credit markets curtailed, as, among other factors, the difficulties inherent in the transition to market econ- omies came increasingly to the forefront. The feared diversion of private sector funds to Eastern Europe at the expense of other developing countries did not occur in 1990. In general, at a time of unsettled market conditions, creditors appeared to be particularly mindful of the importance of the sustained and credible implementation of sound macroeconomic policies and structural reforms by developing countries, not only by those attempting to re-enter the international capital markets, but also by those that had managed to retain their access to those markets.

The response of global financial markets to the outbreak of the Middle East crisis in August 1990 provides an indication of how the effects of large, unanticipated real sector shocks are transmitted rapidly across both industrial and developing countries. ${ }^{3}$ Asset price movements following the emergence of the Middle East crisis, and the associated sharp rise in oil prices (Chart 3), indicate that market participants anticipated a deterioration in economic fundamentals (e.g., growth and inflation), and an increase in the range of potentially adverse outcomes for other parameters (e.g., interest rates). The term structure of interest rates in both the spot and futures markets in the major industrial countries steepened (or became less inverted) during the first two weeks following the invasion of Kuwait. In the futures market for U.S. Treasury securities, the term structure of anticipated interest rates steepened also in relation to that prevailing in the spot market, an indication of a general expectation that longterm interest rates would rise further relative to short-term rates. At the same time, uncertainty about the financial outlook increased. Anticipated near-term asset price variability-as reflected in options prices-increased sharply on most markets. Not surprisingly, the sharpest increase in anticipated volatility, by a factor of close to three, was for the price of oil. The anticipated volatility of U.S. equity market prices more than doubled, while the implicit volatilities in the markets for U.S. Treasury bonds and Eurodollar deposits also rose sharply. In contrast, the implied volatility in foreign exchange options did not increase significantly.

\footnotetext{
${ }^{3}$ Given data limitations, the timely analysis of an unanticipated market shock such as that represented by the invasion of Kuwait needs to be conducted essentially on the basis of movements in asset prices, including futures and options prices. which can provide valuable and forward-looking information on underlying adjustments in portfolios and changes in expectations. Actual data on capital flows, on the other hand, are available only with a considerable time lag. An analysis in Section II of this report examines how asset prices-in spot, futures, and options markets-responded to the invasion of Kuwait in August 1990 and the outbreak of armed conflict in January 1991, and what those price movements may imply about underlying adjustments in portfolios and expectations.
} 


\section{Chart 2. International Bond Issues by Major Instruments, 1985-90 (In percent)}

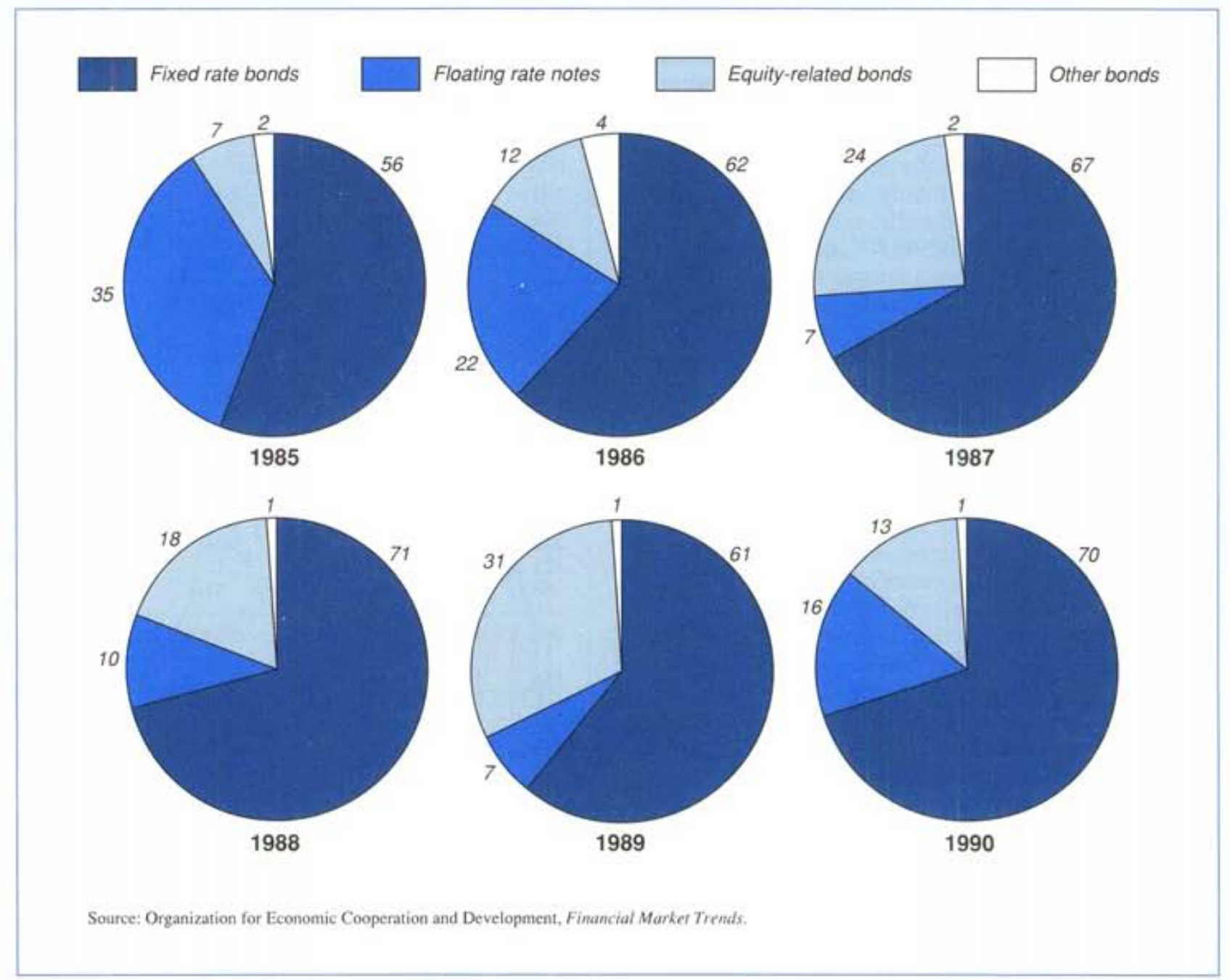

The crisis in the Middle East resulted in a further tightening of market conditions, especially for less creditworthy borrowers. A general preference for safer and more liquid financial instruments was reflected in increased spreads between corporate and government securities on national markets and between private sector Eurobonds and government securities denominated in the same currency on international markets. Despite large asset price movements, however, there were no market disruptions, closures, or significant backlogs. The effects on financial institutions were limited primarily to a number of banks located in the Middle East, which suffered severe liquidity strains that were met, inter alia, through sales of developing country debt holdings, temporarily widening the secondary market discounts on such debt. Elsewhere, the influence was indirect, affecting those banks and securities houses in industrial countries that incorporate unrealized capital gains on asset holdings into their capital positions (notably in terms of the lending behavior of Japanese institutions), or whose loan portfolio (particularly corporate and real estate) was adversely affected by the worsened outlook for economic fundamentals in major industrial countries.

In contrast to market reaction to the onset of the crisis, the response of asset prices to the outbreak of hostilities in January 1991 was less pronounced, apart from a substantial decline in oil prices. Equity prices rose and long-term interest rates declined on both spot and futures markets; the anticipated vol- 
Table 3. International Lending, 1983-Third Quarter 1990

(In billions of U.S. dollars)

\begin{tabular}{|c|c|c|c|c|c|c|c|c|c|}
\hline & & & & & & & & 1989 & 1990 \\
\hline & 1983 & 1984 & 1985 & 1986 & 1987 & 1988 & 1989 & \multicolumn{2}{|c|}{$\begin{array}{c}\text { First } \\
\text { three quarters }\end{array}$} \\
\hline \multicolumn{10}{|c|}{$\begin{array}{l}\text { International lending through banks and } \\
\text { bond markets } \\
\text { Total } 1.2\end{array}$} \\
\hline IMF-based & 212 & 245 & 353 & 625 & 854 & 636 & 917 & 659 & 462 \\
\hline BIS-based (gross) ${ }^{3}$ & 152 & 187 & 309 & 598 & 650 & 518 & 783 & 547 & 344 \\
\hline BIS-based (net of redepositing) ${ }^{3}$ & 131 & 152 & 182 & 282 & 351 & 327 & 487 & 348 & 325 \\
\hline Bond issues (net) ${ }^{4}$ & 46 & 62 & 77 & 87 & 51 & 77 & 97 & 78 & 30 \\
\hline \multicolumn{10}{|l|}{ Change in bank claims 1.2} \\
\hline IMF-based & 166 & 183 & 276 & 538 & 803 & 559 & 820 & 581 & 432 \\
\hline Growth rate (in percent) & 6 & 7 & 10 & 17 & 20 & 11 & 15 & 11 & 7 \\
\hline BIS-based (gross) & 106 & 125 & 232 & 511 & 599 & 441 & 686 & 469 & 314 \\
\hline Growth rate (in percent) & 7 & 6 & 11 & 20 & 18 & 10 & 15 & 11 & 6 \\
\hline BIS-based (net of redepositing) & 85 & 90 & 105 & 195 & 300 & 250 & 390 & 270 & 295 \\
\hline Growth rate (in percent) & 8 & 7 & 8 & 13 & 17 & 11 & 17 & 12 & 12 \\
\hline \multirow{2}{*}{\multicolumn{10}{|c|}{$\begin{array}{l}\text { International lending to industrial } \\
\text { countries } \\
\text { Total }\end{array}$}} \\
\hline & & & & & & & & & \\
\hline IMF-based & 156 & 183 & 271 & 490 & 592 & 538 & 645 & 481 & 411 \\
\hline BIS-based (gross) ${ }^{3}$ & 106 & 148 & 249 & 473 & 482 & 427 & 608 & 435 & 281 \\
\hline BIS-based (net) ${ }^{3}$ & 85 & 113 & 121 & 157 & 183 & 236 & 312 & 236 & 262 \\
\hline Bond issues (net) 4 & 36 & 51 & 63 & 77 & 44 & 67 & 81 & 68 & 25 \\
\hline \multicolumn{10}{|l|}{ Change in bank claims } \\
\hline IMF-based & 120 & 132 & 208 & 413 & 548 & 471 & 564 & 413 & 386 \\
\hline Growth rate (in percent) & 8 & 8 & 13 & 21 & 21 & 14 & 15 & 11 & 9 \\
\hline BIS-based (gross) & 70 & 97 & 186 & 396 & 438 & 360 & 527 & 367 & 256 \\
\hline Growth rate (in percent) & 4 & 5 & 9 & 15 & 13 & 9 & 12 & 8 & 5 \\
\hline BIS-based (net) & 49 & 62 & 58 & 80 & 139 & 169 & 231 & 168 & 237 \\
\hline Growth rate (in percent) & 5 & 5 & 5 & 5 & 8 & 8 & 10 & 7 & 9 \\
\hline \multirow{2}{*}{\multicolumn{10}{|c|}{$\begin{array}{l}\text { International lending to developing } \\
\text { countries } \\
\text { Total }\end{array}$}} \\
\hline & & & & & & & & & \\
\hline IMF-based & 32 & 14 & 8 & 5 & 23 & -4 & 13 & 7 & -12 \\
\hline BIS-based ${ }^{3}$ & 28 & 10 & 17 & 4 & -10 & 5 & 10 & -12 & -17 \\
\hline Bond issues (net) ${ }^{3.4}$ & 2 & 3 & 4 & 2 & 1 & 2 & 2 & 1 & 1 \\
\hline \multicolumn{10}{|l|}{ Change in bank claims' } \\
\hline IMF-based & 30 & 11 & 4 & 3 & 22 & -6 & 11 & 6 & -13 \\
\hline Growth rate (in percent) & 6 & 2 & 1 & - & 4 & -1 & 2 & 1 & -2 \\
\hline BIS-based & 26 & 7 & 13 & 2 & 9 & 3 & -12 & -13 & -18 \\
\hline Growth rate (in percent) & 7 & 1 & 3 & - & 2 & - & -2 & -2 & -3 \\
\hline \multicolumn{10}{|l|}{ Memorandum items } \\
\hline $\begin{array}{l}\text { Total gross bond issues } \\
\text { Of which: }\end{array}$ & 77 & 110 & 168 & 227 & 181 & 227 & 256 & 197 & 172 \\
\hline Industrial countries & 60 & 91 & 138 & 201 & 156 & 198 & 224 & 172 & 143 \\
\hline Developing countries $^{5}$ & 3 & 4 & 8 & 4 & 4 & 6 & 5 & 3 & 4 \\
\hline
\end{tabular}

Sources: Bank for International Settlements (BIS); Organization for Economic Cooperation and Development (OECD); International Monetary Fund, International Financial Statistics; and Fund staff estimates.

'IMF-based data on cross-border changes in bank claims are derived from the Fund's international banking statistics (IBS) (cross-border interbank accounts by residence of borrowing bank plus international bank credits to nonbanks by residence of borrower), excluding changes attributed to exchange rate movements. BIS-based data are derived from quarterly statistics contained in the BIS's International Banking Developments; the figures shown are adjusted for the effects of exchange rate movements. Differences between the IMF data and the BIS data are mainly accounted for by different coverages. The BIS data are derived from geographical analyses provided by banks in the BIS reporting area. The IMF data derive cross-border interbank positions from the regular money and banking data supplied by member countries, while the IMF analysis of transactions with nonbanks is based on data from geographical breakdowns provided by the BIS reporting countries and additional banking centers. Neither the IBS nor the BIS series are fully comparable over time because of expansion of coverage.

${ }^{2}$ Total changes in bank claims include offshore centers, international organizations, and other non-Fund members, as well as industrial and developing countries.

'Estimates based on BIS and OECD data.

Net of redemption and repurchases, and of double counting, that is, bonds taken up by the reporting banks to the extent that they are included in the banking statistics as claims on nonresidents and bonds issued by the reporting banks mainly for underpinning their international lending activity.

'Excludes the seven offshore centers (The Bahamas, Bahrain, the Cayman Islands, Hong Kong, the Netherlands Antilles, Panama, and Singapore). 
Chart 3. Oil and Gold Prices,

July 6,1990 -January $25,1991^{1}$

(In U.S. dollars)

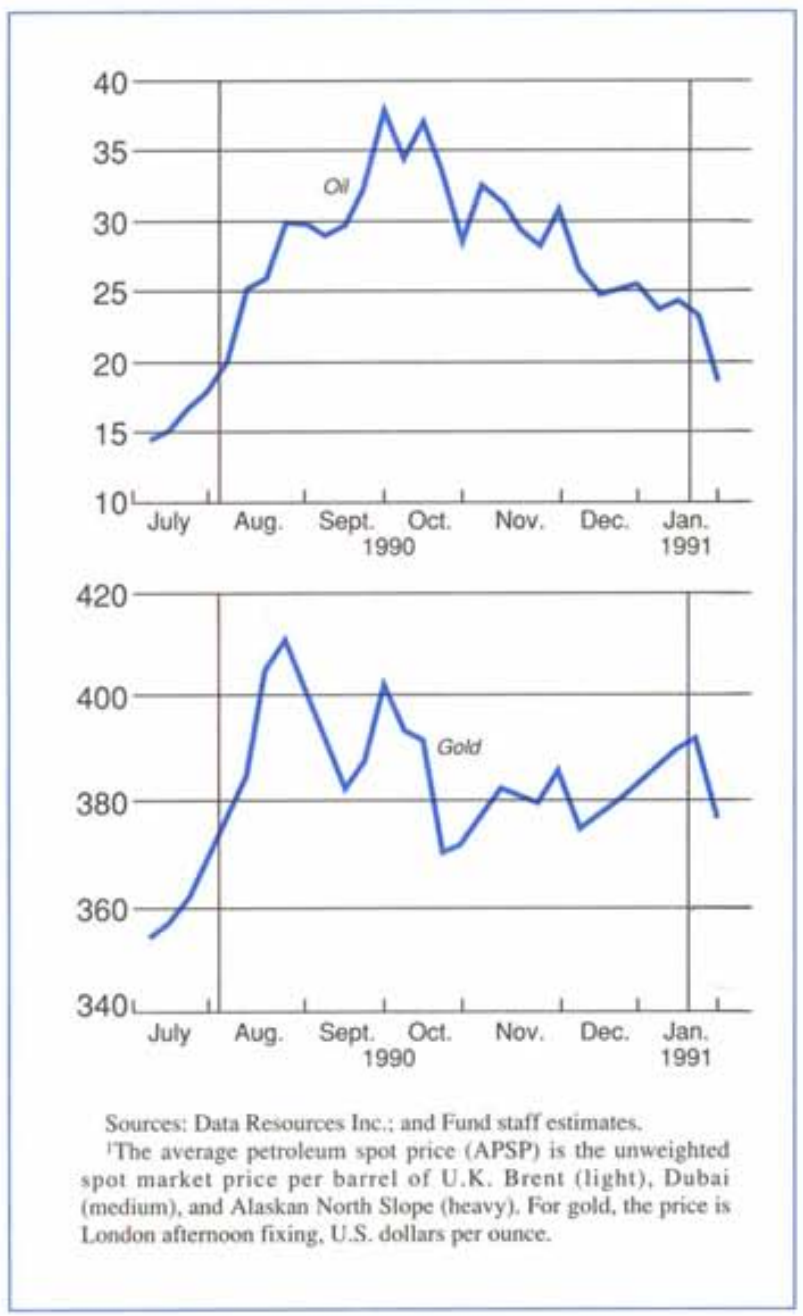

atility of prices for oil, bonds, and equities also fell. The difference in the adjustments of asset prices in August 1990 and in January 1991 appears to reflect the fact that the earlier event was largely unanticipated; market participants responded more abruptly and with less information. In such a situation, asset price adjustments are likely to be sharper and more extensive. The events of January 1991, in turn, were anticipated to a comparatively larger extent and elicited more moderate adjustments in portfolios.

\section{Spontaneous Financing for Developing Countries}

Developing countries' access to spontaneous credit on international capital markets has, with the exception of a few countries, been severely curtailed since 1982. Against this background, it is noteworthy that some developing countries with recent debt-servicing problems succeeded during 1989-90 to gradually restore a degree of access to spontaneous capital flows, most notably through bond issues and flows into their domestic equity markets; to date, however, the amounts have been modest and the phenomenon limited to a narrow range of countries. In addition, several developing countries that have maintained access faced a tightening of market conditions in 1990.

Spontaneous medium- and long-term bank credit commitments to capital importing developing countries amounted to $\$ 16.5$ billion in $1990-11$ percent above the level attained in 1989. This increase was largely attributable to the sustained growth of bank credit commitments (to $\$ 10.7$ billion, a 20 percent rise) to traditional Asian borrowers and a strong increase in commitments to the Soviet Union (in large part guaranteed by Organization for Economic Cooperation and Development (OECD) governments). At the same time, although small in overall terms, there was a resumption in spontaneous bank credit commitments, mainly project related, to several borrowers in the Western Hemisphere (Chile, Mexico, and Venezuela). In contrast, there were no new spontaneous bank commitments to Eastern European countries, reflecting not only political uncertainty but also fear of contagion effects following the suspension of payments by Bulgaria in March 1990.

A limited return to spontaneous access by countries with recent debt-servicing problems was also evident in securities markets, which have in fact constituted the main point of market re-entry for countries with recent debt-servicing difficulties. This possibly reflects factors such as the still modest overall amount of developing country bond debt outstanding and the relatively good servicing record on such instruments. International publicized bond issues by developing countries in 1990 amounted to $\$ 5.1$ billion, compared with $\$ 4.5$ billion in 1989 . In addition, partial information on private placements and other unpublished bond issues by developing countries indicates that they amounted to some $\$ 1.5$ billion in 1990 . Together with substantial issues by traditional Asian borrowers (India, Indonesia, Korea, and Malaysia), the higher volume of bond issuance included an estimated $\$ 2.4$ billion of public issues and private placements by entities in two Western Hemisphere countries with recent debtservicing problems (Mexico and Venezuela). ${ }^{4}$ Bond issues by three traditional Eastern European bor-

\footnotetext{
4 Excluding bonds issued as part of debt-restructuring packages.
} 
rowers (Bulgaria, Czechoslovakia, and Hungary) were broadly stable between 1989 and 1990 (about $\$ 1.3$ billion), but the composition of new issues changed sharply (no issues by Bulgaria, and an increase from $\$ 74$ million to $\$ 377$ million in Czechoslovak issues). Bond issues by the Soviet Union (at \$298 million) equaled only about one third of their 1989 level.

Portfolio equity flows to developing countries increased in 1989-90, mainly through country specific and multicountry funds (an estimated $\$ 1$ billion a year) but also, more recently, through equity issues by developing country corporations on industrial country stock exchanges. Foreign portfolio investors have also acquired equity participation in developing country corporations in the context of privatization programs. New issues of country funds came to a virtual halt in the latter half of 1990, following a period of rapid expansion and consequent market saturation, as well as a slowerthan-anticipated deployment of funds in Eastern European countries.

\section{Recent Structural Changes in Financial Markets}

Previous reports in this series have described the structural changes in financial markets arising from liberalization, market integration, and the spread of innovative financing instruments and techniques. These trends continued, and in some cases intensified, in 1989-90, increasing competition among major financial centers and institutions and diminishing segmentation between various sectors of domestic and international markets. Although these phenomena are frequently depicted as global in scope, it should be noted that few developing countries are directly involved in them and important structural differences persist across the main industrial countries. Distinctions remain, for example, in the extent and nature of links between banking and commerce, the degree of financial concentration, the role of securitized money markets, the organization of national stock exchanges, and the taxation of financial activities.

The process of deregulation of financial sector prices (such as interest rates, fees, and commissions), which began in earnest in the 1980s, is now largely complete in most industrial countries. During the past two years, direct controls on interest rates have disappeared or been reduced to the point of insignificance, with, in particular, further deregulation (or the erosion of longstanding cartel-like arrangements) in Austria, France, Japan, and Switzerland. In Japan, where interest rate controls have long been a prominent feature of the financial system, deregulation proceeded more decisively in the past year; in July 1990, the authorities announced a three-year timetable for the complete liberalization of rates on time deposits, and an advisory council is currently deliberating moves to deregulate rates on demand deposits. This process significantly raised the average cost of funds for Japanese banks and probably contributed to their retrenchment from lowmargin cross-border activity. Similarly, the process of replacing fixed fees and commissions for financial services with freely negotiable ones continued in most of the countries where it had not yet been completed, and most notably in Switzerland.

Restrictions on the range of financial institutions " activities also continued to erode, either through market practice or through legislative and regulatory action. In addition to the blurring of distinctions between banking and the securities business, a more recent development has been a deepening of linkages between banking and insurance. In an increasing number of countries, the policy consensus has been shifting away from legally imposed specialization of financial services toward allowing market participants to decide for themselves the degree of functional diversification they wish to pursue, within appropriate regulatory and supervisory safeguards. In all of the three major economies with traditionally segmented systemsCanada, Japan, and the United States-there have been moves toward a relaxation of functional barriers. Policy movement is most advanced in Canada, where reform proposals presented by the federal government in September 1990 would eliminate many of the remaining restrictions between the "four pillars" of banking, securities, trust, and insurance companies. In Japan, a revision of the policy separating banks and securities houses is under consideration. In the United States, a detailed set of proposals concerning deposit insurance and financial regulatory reform was released by the Treasury Department in February 1991; the proposals included significant changes in laws that have long restricted the conjunction of banking and securities functions under one corporate charter and the expansion of banks across state lines.

As increased linkages across a range of financial services become more widespread, there appears to be a general trend toward the emergence of financial conglomerates. ${ }^{5}$ Contrasting trends, however, are

\footnotetext{
s The term "financial conglomerate" is used to describe an integrated group that provides different types of financial services, including a number or all of the following: deposittaking and lending (including mortgage lending), securities transactions, leasing, credit card services, mergers and acquisitions, and-more recently in some cases-also insurance services. In nearly all OECD countries, however, the business of insurance underwriting is regulated under special laws, and banks are not permitted to underwrite insurance business directly.
} 
also in evidence. Diversification strategies have been developed mainly by large institutions as a means of consolidating positions in their home markets, while domestic or foreign newcomers to these markets have often adopted a specialized "niche" approach to establishing initial footholds. Furthermore, some amount of "re-specialization" is taking place in some large institutions themselves, as they retrench from highly competitive market sectors characterized by overcapacity (e.g., securities trading in some major financial centers). This is especially evident in the restructuring programs announced in 1990 by a number of major internationally active banks. Nevertheless, the underlying trend toward the formation of financial conglomerates appears to be deeply rooted, raising difficult challenges for supervisory authorities.

Movement toward the geographic integration of financial markets has been especially pronounced within the European Community. As part of the 1992 single market program, major directives affecting the banking market were adopted in 1989 and the transposition of these directives into national legislation is under way. ${ }^{6}$ Meanwhile, discussions on directives for a single market in the securities field are continuing. In addition, the directive on the liberalization of capital movements within the EC came into effect in July 1990, by which time most EC members had already fully implemented it. Complementing these measures were the negotiations on economic and monetary union (EMU), which culminated during the period under review with the initiation of the intergovernmental conference in December 1990.

The overall process of European integration is viewed by many market participants in Europe, both in EC member and nonmember countries, as constituting the single most important influence on their activities and strategies for the 1990s. Views differ, however, as to the ultimate direction of structural change, in banking as well as in other financial markets. With regard to banking, the single market is seen by some as likely to entail a gradual convergence toward a multipurpose or universal banking model, as universal banks authorized to conduct, for example, securities underwriting in their home country will, by virtue of the single license, be able to do so in other member countries, even those that at present restrict their own banks from such activity. An alternative view is that specialized institutions might prove more adaptable and efficient in taking advantage of the

6 The Second Banking Coordination Directive, which established the single banking license concept, and the Own Funds and Solvency Directives, which established banks' risk-based capital requirements. larger and more competitive European market than universal banks. In practice, the prospect of the 1992 single market has not yet led to substantial or widespread cross-border organizational mergers, and most European banks appear to have opted to strengthen their domestic bases, thus far limiting their cross-border ambitions to wholesale or niche activities.

Progress within the EC on a single market in the securities field has been slower. ${ }^{7}$ There are two main outstanding issues in this regard. The first concerns the organization of national exchanges; among other things, at issue is the extent to which securities business should pass through recognized national exchanges or be allowed to take place outside those exchanges. Distinctive national approaches to such questions reflect differences in the established practices of member country exchanges, as well as competitive considerations and different ways of reconciling the objectives of market efficiency and investor protection. The second issue involves capital adequacy standards for securities firms, including banks engaged in securities activities. The directive currently in draft form allows supervisors in member countries with nonsegregated (universal) systems to choose between applying existing bank capital adequacy requirements to a universal bank's aggregate activities and "carving out" a bank's securities trading book for application of the securities' standards. By early 1991, this approach had not fully satisfied some member countries' concerns that requirements imposed on banks and nonbank securities firms be broadly equivalent to avoid creating competitive distortions.

\section{Financial Policy Issues}

Recent developments in international financial markets have raised a number of issues of concern for public policy, three of which are worthy of particular examination. First, indications of the possible fragility of financial institutions and markets in a number of major industrial countries, especially in the face of economic downturns, have garnered considerable attention in policy circles. Second, perceptions of what observers have tended to group under the general heading of a global "credit crunch" have caused disquiet. In this regard, it may be observed that this term normally applies to situations that give rise to quantity rationing of credit and not just situations characterized by high interest rates. In the current public debate, however, the

\footnotetext{
7 As embodied in the European Commission's draft directives on Investment Services and on Capital Adequacy for Investment Firms and Credit Institutions.
} 
term is frequently used also to indicate a possible global shortage of capital, in which sharply increased demands for funds might not be matched ex ante by higher global saving at current levels of real interest rates. ${ }^{8}$ A third policy issue, partly framed by the other two, concerns the prospects for developing countries' access to spontaneous credits and for the re-entry to international capital markets by some developing countries with recent debtservicing problems.

\section{"Financial Fragility"}

A number of interrelated factors have placed downward pressure on profit margins of banks in all industrial countries, albeit to differing degrees. The loss of banks' traditional advantages in extending credit to prime corporate borrowers and in providing other financial services has undercut the once considerable value of a banking franchise. The effects of intensified competition and erosion of market share have, in many cases, been compounded by an element of greater risk taking, with an excessive concentration of exposure to certain categories of borrowers. In a number of countries, such exposures may be traced to the way the most recent credit cycle unfolded, with an extended period of rising real estate and equity prices paving the way for a sharp expansion in borrowers' leverage ratios, and an associated miscalculation of risks by commercial bank lenders. As those prices began falling, the deteriorating quality of bank portfolios has required increasing provisions against nonperforming loans, in some cases eroding banks' capital bases. Exposure to commercial real estate lending is now the main source of deteriorating asset quality for banks in a number of countries, following a strong expansion of such lending during the 1980 s. U.S. commercial banks' domestic property loans increased from 29 percent of assets in 1980 to 37 percent by 1989 ; for the United Kingdom, the share doubled to 23 percent over the same period; and it is estimated at around 17 percent (10 percent excluding the construction industry) for Japanese city banks, many of which have also engaged in substantial property lending abroad. ${ }^{9}$

Market response to banks' deteriorating asset quality and low profitability has been reflected in downgraded credit ratings, a sharp fall in many

\footnotetext{
${ }^{8}$ Ex post, of course, the two are by definition equal (abstracting from any statistical discrepancies), but possibly at the cost of some crowding out of anticipated or desirable investment for growth and development.

${ }^{9}$ Data not strictly comparable across countries; in particular, data for Japan exclude a considerable amount of real estatebacked lending in the form of loans to leasing companies and other nonbank financial institutions.
}

banks' stock prices, and a marked increase in their cost of tapping confidence-sensitive sources of funds. Credit downgradings were numerous in 1990, particularly in the United States and Japan. Downgradings in Europe were more limited, although there too greater competition and disintermediation-both likely to be intensified by the EC 1992 program-have affected the quality of bank assets and eroded profitability, especially in the United Kingdom. Market participants have also noted the potential risks involved in German banks' ventures in the former German Democratic Republic; although by the end of the period under review those banks remained strong even if profit growth had decelerated.

With regard to banks' stock prices, during 1990 shares of some major U.S. banks fell by as much as two thirds and those of Japanese banks by between 40 percent and 50 percent. Exacerbating the effects of such declines, yields on confidence-sensitive sources of bank funding, such as subordinated debt and preferred stock issues, rose significantly, particularly for major money center banks in the United States. In some cases, record premiums of up to 500 basis points over U.S. Treasury securities of comparable maturity were recorded. Partly in consequence of such developments, traditional pressures from banks' end-of-year balance sheet window-dressing operations emerged at an unusually early stage during 1990. These actions and reactions would suggest that, despite the existence of official safety nets, there are still important elements of market discipline imposed on financial institutions.

These developments reflected a growing sense of the fragility of financial institutions during 1990, with increasing concerns that market resilience would be severely tested in the period ahead, especially if the slowdown in economic activity were to be deep, broad, and prolonged. There are also concerns that the weakness of financial institutions might limit the ability of governmental authorities to pursue preferred macroeconomic and regulatory policies, and might also render the necessary processes of restructuring less orderly. Finally, there are concerns that calls on official safety nets and potential claims on public treasuries might be significant. A clear manifestation of these concerns in the United States is given by the actual and projected deterioration in the capitalization of the deposit insurance fund of the Federal Deposit Insurance Corporation (FDIC), owing to the high number of bank failures and increase in related losses.

It is possible, of course, that observers may have exaggerated such concerns. Many major banks are now more adequately capitalized, already meeting the minimum international capital adequacy standards set for the end of 1992 (with the exception 
of a few U.S. and most Japanese institutions which, nonetheless, met year-end 1990 transitional requirements). Most banks now are also well provisioned against developing country exposure, and there are signs of better risk-based pricing and greater selectivity in lending. Moreover, many banks have undertaken or announced wide-ranging restructuring programs to reduce costs. While acknowledging the need for financial institutions and the regulatory framework to adapt to the new conditions, authorities in most industrial countries have tended to take the view that such adaptation would not be advanced by an easing of regulatory and supervisory standards, a position endorsed by the Basle Committee on Banking Supervision. On the contrary, there has been generally an increased emphasis on enhancing supervisory oversight, strengthening payments systems, and reassessing the role of official safety net provisions. Such an approach was, for example, evident in the February 1991 regulatory reform proposals of the U.S. Treasury Department.

\section{Global Credit Pressures}

Various pressures on both the demand and supply sides of the international capital markets have reawakened concerns about the level and allocation of world savings. Such concerns became especially prominent as international interest rates climbed over most of the past year, and as the availability of credit became constrained, even to the point where certain borrowers appeared to be subjected to nonprice rationing. Fears about the deleterious consequences of a severe credit tightening were most obvious in certain domestic economies, prompted by concerns that reductions in bank lending could adversely affect economic activity if otherwise creditworthy firms could not obtain the financing needed for their current operations and if such retrenchment exacerbated declines in asset prices. Such fears, for example, underlay moves by the U.S. Federal Reserve in the latter part of 1990 to lower interest rates and reduce banks' reserve requirements, with these measures being accompanied by official calls on banks to avoid "unwarranted" credit stringency.

Several key factors are seen to sustain the worldwide demand for funds. They are not easy to quantify, as some factors represent actual demands in the short term and have immediate effect, while others represent potential or pent-up longer-term investment requirements for broad public purposes and their effective impact is accordingly different. Undoubtedly, one major factor influencing the demand side is German unification, which, by virtue of its fiscal impact, will sharply cut into net saving in Germany. There are also the potentially significant financing demands associated with restructuring in Eastern Europe and with postwar reconstruction in the Middle East. These demands augment the continued needs of developing countries for additional resources. Large-scale privatization programs in these and other countries are also perceived to bring further pressures to bear on scarce global savings, as are environmental programs in several countries. Investment demand in some industrial countries is expected in the longer term to reflect pent-up needs to improve and replace outmoded public infrastructure and to enhance productivity in the context of changing demographic profiles.

Against these sources of present and future demand, various factors are widely perceived to be restraining the global supply of saving. While a secular decline in private saving rates appears to have halted or even reversed in some countries, demographic factors are expected to prevent any significant rebound, and public sector dissaving remains high in many countries. Compounding such factors may be constraints on bank intermediation, arising from the response by commercial banks to tighter regulatory and supervisory regimes, and in particular to more stringent capital requirements. In many cases, responses to those requirements have entailed substantial new capital-raising efforts (e.g., the large international issues of subordinated bonds by Japanese banks) and, given a rising cost of capital, contractions in assets, either in relative or absolute terms. Cross-border activity has been the prime area for such contraction, as most banks have given priority to maintaining their domestic client bases. In this context, the question has arisen of whether there is in actuality, or is bound to be, a shortfall in financing of otherwise deserving undertakings, and consequently a less-than-optimum rate of investment and output growth, because of the need (or preference) of banks to scale down asset growth.

It is this combination of large anticipated investment needs, relatively low saving, and bank lending restraint that has fueled credit crunch concerns and associated worries that optimum rates of investment and growth would not be achieved over the near term. It is possible, however, that expectations along these lines are exaggerated. The aggregate impact of privatization schemes on global capital markets, for example, is likely to be less than sometimes suggested. Experience indicates that countries with ambitious privatization programs will often still need to put into place the necessary macroeconomic, legal, and institutional preconditions for achieving programmed levels of asset sales, and that the operations which eventually do take place are likely to be less than those preannounced and 
will be spread over an extended period of time. ${ }^{10}$ Furthermore, privatization schemes, even when implemented, need not affect the net demand for loanable funds when they serve as a substitute for the net issuance of government debt or, as was the case with recent debt-equity conversions in Argentina, when they involve the retirement of outstanding liabilities. On the issue of bank lending restraint, some observers take further comfort in the view that disintermediation has, in fact, reduced corporate reliance on bank credit to a considerable extent. Moreover, some observers have welcomed a correction in what was generally judged to have been a disturbing earlier propensity on the part of banks to pursue asset growth for its own sake. Finally, the economic slowdown in a number of countries is in itself seen as dampening investment demands.

Despite the above qualifiers, on balance, the behavior of international interest rates over the past year, particularly at the long end of the maturity spectrum, appears to suggest that the worldwide demand for saving relative to supply remains strong. This would underscore the importance and urgency of increasing world saving, both through an acceleration of the process of fiscal consolidation, particularly in countries where fiscal deficits remain high, and through measures to encourageor, in some cases, to remove disincentives-for greater private saving. For developing countries, the environment of tougher international competition for investment capital, together with the investor flight to quality, highlights the crucial importance of sound policies to maintain or restore creditworthiness.

\section{Market Re-Entry of Developing Countries}

Developing country borrowers attempting to regain access to spontaneous private financing in international markets clearly confront difficult obstacles. Negative market perceptions are not easy to overcome given concern about past debtservicing performance (reflected, for example, in substantial secondary market discounts on bank claims (Chart 4)), the complexities creditors face in evaluating sovereign risk, and the absence of wellestablished and enforceable seniority arrangements to protect new private flows or segregate them from old claims. Nonetheless, a few highly indebted middle-income developing countries, particularly in Latin America, have in the past two years initi-

${ }^{10}$ In Eastern Europe, for example, relatively large sums raised by country funds for equity investment have remained undeployed for lack of attractive investment opportunities. In the former German Democratic Republic, uncertainty regarding property rights has also slowed the privatization process. ated a modest return to spontaneous market access, following a long period of exclusion. While limited in scope, their initial experiences raise important policy issues and provide insight into the possible features that a more general process of market reentry could take.

A precondition for restoring market access is the sustained implementation of appropriate adjustment policies, reinforced by structural reform efforts. For countries perceived by the market to be excessively indebted-reflected in relatively high risk-related yields on domestic and external debt instruments-such efforts can be assisted by comprehensive restructuring of the existing commercial bank debt stock, as well as by debt relief granted by official creditors. The combination of good policies and, where necessary, lower contractual debtservice burdens, can help reduce risk premiums to levels that investors do not consider so high as to denote severe and insurmountable financial weakness, and that developing country borrowersespecially private sector corporate entities-are willing and able to pay.

The perception of the risks involved in holding claims on developing country borrowers has also been reduced for certain classes of debt by a differentiation in payment policies, that is, by giving certain instruments a de facto (or expected) priority in payment and excluding them from rescheduling exercises. Thus, for example, developing countries experiencing payments difficulties on private sector debt have sought to protect flows vital to their economies, such as trade and interbank credit, by giving them priority in servicing. Some major developing country debtors have, for similar reasons, during the past two decades, continued to discharge their international bond obligations on a timely basis, despite general payments difficulties; it should be noted that such obligations typically represent a relatively small share of total debt service due.

The secondary market for developing country debt appears to have incorporated perceptions of payments priorities on different types of debt by the same sovereign borrower, with these debts trading at significantly different implicit yields. This tiering in pricing, which reflects perceptions of de facto seniority, has helped make room for new issues by private sector developing country borrowers at yields that compare favorably with (i.e., are somewhat lower than) yields implicit in secondary market prices for the old bank debt-now securitizedof their respective governments. It should be noted, however, that well-established enforceable seniority arrangements do not exist for international contracts involving sovereign risk. Prioritizing debt service on certain types of claims, either at the initiative of the debtor or by voluntary agreement with creditors, is thus essentially an informal exercise 
Chart 4. Secondary Market Prices for Developing Country Loans ${ }^{1}$

(In percent of face value)

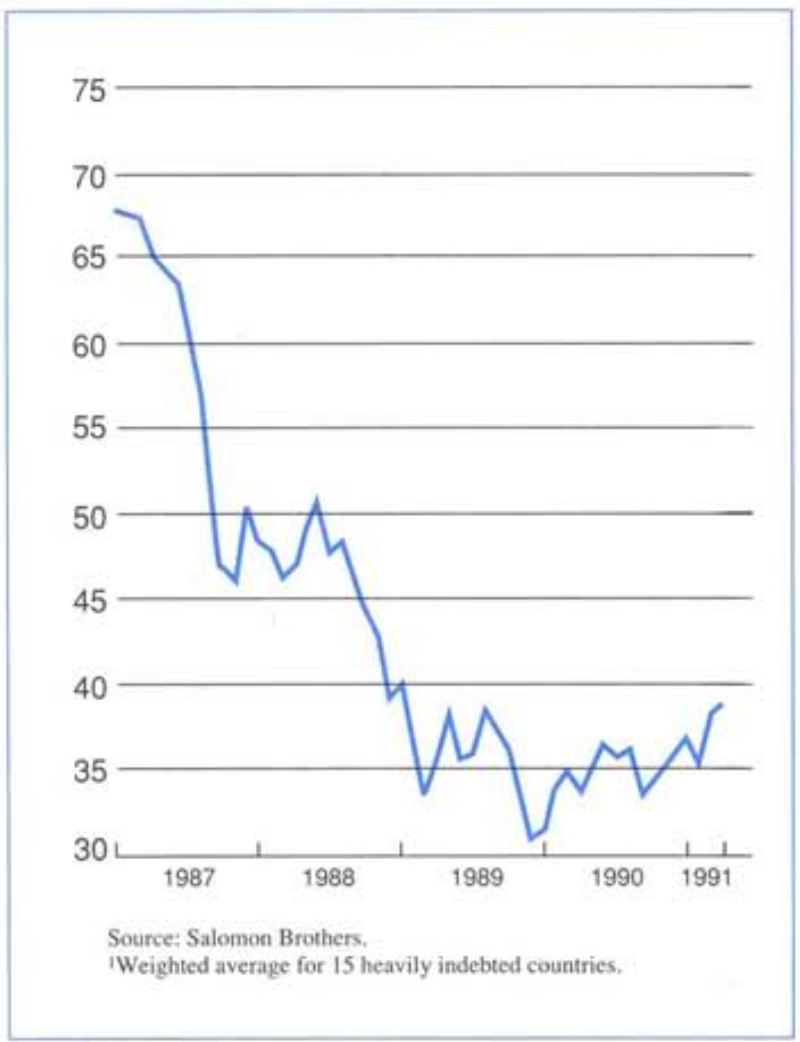

not likely to prove fully credible to all market participants.

New developing country borrowings have also been facilitated by the expanded use of specific financing techniques that seek to reduce direct country risks incurred by lenders. Careful customizing of debt issues to the needs of particular markets (timing, pricing, maturity, choice of currency, redemption clauses, etc.) is considered essential, especially when overall market conditions are tight. One technique that has been used to a significant extent by borrowers from countries with recent debt problems is collateralization. This technique provides lenders with the right to take possession of certain specified assets in the event of default; to this end, lenders usually require that taking possession and disposing of the collateral are free of operational complications and uncertainties. Collateralization has been used predominantly by developing country corporate borrowers or public sector corporations raising debt without explicit guarantees from their central governments. Various kinds of assets have been pledged as collateral, including foreign exchange receivables generated abroad, claims to assets located abroad, and commodity swaps. ${ }^{11}$

Collateralization may play an important role in overcoming credit rationing and, in particular, it can serve a useful purpose for nonsovereign borrowers that are new entrants to markets and are establishing their reputations. At the same time, however, the technique does have some limitations. Potential reductions in the seniority of creditors with unsecured claims can be problematic. Difficulty can arise, for example, when newly pledged assets, such as accounts receivable, could be used to service general obligations. By earmarking such assets, the debtor in effect loses flexibilityparticularly should short-term liquidity problems arise-and raises the risk of loss for other claim holders. These risks of subordination could be of particular concern to international financial institutions who hold preferred creditor status. In view of such considerations, creditors have often included negative pledge clauses in their loan contracts that may block any pledge of collateral on new contracts. A related limitation of collateralization is that its excessive use could impair, rather than improve, a borrower's prospects for future market access on an unsecured basis. By unduly encumbering its assets through liens, a borrower may thereby significantly raise its future financing costs. The benefits of obtaining liquidity now through the pledge of collateral must thus be weighed against such future costs.

Although clearly less important than debtors' policies and initiatives, it should be noted that, on the creditor side, regulations in industrial countries may also play a role in debtors' return to market access. Loan-loss provisioning requirements, for example, can affect the willingness of banks to hold new debt instruments issued by countries with recent debt-servicing problems. Banks have, in fact, in recent years increased their average provisions against losses on developing country credits in response to both regulatory requirements and market pressures. While specific provisioning regulations vary from country to country, average provisioning levels against developing country exposure exceed 50 percent in all of the main creditor countries except Japan. In general, provisioning requirements are to a large extent set and determined by backward-looking factors (particularly, past debtservicing problems), and they tend to respond with a lag to recovery in debtors' prospects. In some countries, for example, provisioning regulations specify that loan-loss reserves must be maintained at least five years after the most recent rescheduling

\footnotetext{
1 For further detail, see Section V below.
} 
agreement. Consequently, while some developing countries have succeeded in restoring limited spontaneous market access, bank claims on them are, in most cases, subject to unchanged provisioning requirements. Only a few regulatory systems explicitly provide for flexibility in "graduating" a country from mandatory provisioning lists following evidence of an improvement in prospects. To the extent that the process of market re-entry progresses, increased attention will likely need to be devoted to assuring an appropriate degree of flexibility in provisioning requirements, while maintaining prudent banking practices.

A final consideration that arises from the primary role played by portfolio flows, rather than syndicated bank lending, in the process of developing countries' market re-entry as witnessed to date concerns the catalytic role of the Fund. While syndicated bank lending packages could in some cases be mobilized as part of the overall support of the international financial community for a country's adjustment efforts, private sector portfolio flows will usually only respond to clear changes in economic prospects of indebted countries brought about by the pursuit of appropriate financial and structural policies, that is, to circumstances that enhance the risk-adjusted yield of debt instruments relative to those available elsewhere. In this context, the catalytic role of Fund-supported adjustment programs vis-à-vis private sources of financing essentially takes the form of helping members to adopt and sustain policies that promise to restore investor confidence and establish an environment conducive to capital reflows. Flight capital, in particular, perhaps being associated with investors with a more intimate knowledge of a debtor country's circumstances, appears to be highly responsive to confidence-building changes in policy. In Mexico, for example, the sustained implementation of adjustment efforts, including specific policy actions to remove obstacles to capital flows, together with the finalization of a commercial bank financing package, was associated with significant inflows of private capital, especially in the form of foreign direct and portfolio investment as well as capital repatriation. Among other reforms, the setting of realistic exchange rate and interest rate policies from the outset of adjustment and, as conditions permit, the lifting of capital controls can turn around investor sentiment and rebuild confidence in a country's economic and financial prospects.

During the period under review, the importance of complementing such reforms with the liberalization of domestic financial markets has been particularly highlighted in Eastern Europe. Recent experience in Poland and elsewhere has demonstrated that a solvent and effectively supervised banking system, connected through an interbank market and supplemented by a money market and a market for claims on real assets, is a prerequisite not only for effective monetary control but also for successful privatization. Fostering such reforms is an extensive program of technical assistance being provided by the Fund to Eastern European countries, both directly and through coordinating assistance provided by various industrial country central banks.

\section{Public Policy Response to Strains in the Financial System}

At the turn of the decade, the main financial market trends of the $1980 \mathrm{~s}$-liberalization, globalization, and technological innovation-have profoundly changed the nature of domestic and international capital markets. In all countries, the authorities are striving to define the proper supervisory framework for ongoing changes and to balance the requirements of market efficiency and overall safety and soundness. In general, supervisory regimes have been strengthened in light of the greater risks that intensified competition has brought to financial systems, and in order to promote the cost-effectiveness of official safety nets. There appears to be an emerging consensus, partly as a result of the thrift crisis in the United States, that continuing movement toward financial liberalization and deregulation needs to be accompanied by more effective supervision. In this approach, intensifying supervision while deregulating markets is seen to be a logical, rather than a contradictory, course of action. This approach, however, is seen by some market participants as entailing an objectionable degree of re-regulation, especially where the financial environment is already viewed as fragile. In such an environment, the correct balance to be struck by the authorities is clearly a delicate and complex one.

Efforts to strengthen supervision are being conducted internationally as well as nationally. Work continues under the auspices of the Basle Committee on Banking Supervision, the International Organization of Securities Commissions (IOSCO), and the Commission of the European Communities. Partly in consequence of policy movements in the direction of harmonization and cooperation, earlier concerns about "beggar-thy-neighbor" competition between national regulatory and supervisory systems and the related process of unchecked "regulatory arbitrage," appear to have receded somewhat.

\section{Reassessing Official Safety Nets}

The financial fragility concerns noted above have focused increasing attention on the role of official safety nets, created in all major industrial countries 
to promote financial stability and prevent financial disturbances from spilling over into the real economy. Safety nets, whether in the form of explicit guarantees or implicit commitments, essentially manifest recognition of the unique elements of systemic risk inherent in banking and finance and of the "public good" provided by fundamental market soundness. Official safety nets typically encompass the provision of emergency liquidity assistance by central banks and some form of depositor protection through private or official insurance. While these safety nets have undoubtedly helped to contain the broader effects of financial disturbances at times of stress, they also by their nature expose the authorities to credit risk from various sources. To contain such risk, official safety nets are increasingly viewed as constituting integrated systems, in which official guarantees extended to the system are balanced by minimum capital adequacy standards and other prudential requirements.

Recent financial problems in some major industrial countries, notably the United States, along with the increased integration of national markets and expansion of cross-border financial activities, have heightened concerns about the credit risks to which governments are exposed through official safety nets and the potential budgetary implications arising from the associated contingent liabilities. A first set of concerns, and the one currently receiving most attention in the United States, emanates essentially from the "moral hazard" dilemma. In essence, while official assistance during a financial crisis can limit adverse effects on real activity and income, the expectation that such assistance will be available may alter the behavior of economic agents in such a way as to make a future crisis more likely, for example, by encouraging excessive risk taking. ${ }^{12}$ A second set of concerns, less evident in current public policy debates, but having important systemic implications, including within the process of economic and monetary union in the EC, arises from the fact that, despite the increased crossnational financial integration, official safety nets remain principally organized along national lines. This risks leaving inadequately addressed important questions concerning the prudential supervision of

12 "The safety net-deposit insurance, as well as the discount window-has so lowered the risks perceived by depositors as to make them relatively indifferent to the soundness of the depository recipients of their funds, except in unusual circumstances. With depositors exercising insufficient discipline through the risk premium they demand on the interest rate they receive on their deposits, the incentive of some banks' owners to control risk-taking has been dulled." Statement by Alan Greenspan, Chairman, Board of Governors of the Federal Reserve System, before the Committee on Banking, Finance, and Urban Affairs, U.S. House of Representatives, September 13, 1990, as reproduced in Greenspan (1990), p.917. domestic institutions in foreign markets and of foreign firms in domestic markets, the participation of foreign institutions in national deposit insurance arrangements, the extension of deposit insurance to the foreign operations of domestic financial institutions, and the responsibility for providing emergency liquidity assistance to offshore markets.

On many of these questions, and most specifically on the precise conditions and circumstances under which some types of official financial assistance will be made available, the authorities in major industrial countries have remained purposely vague and ambiguous in an attempt to counter the moral hazard problem. Nevertheless, despite important differences in the explicit or de jure scope and definition of official safety nets in the major countries, their de facto application, in the relatively rare instances in which they have been called upon, has not substantially differed. Thus, for example, while deposit insurance systems in major countries vary widely (in terms of the amount of insurance provided, the institutions allowed or obliged to participate in the system, and the relative roles of private and official insurance), the authorities concerned have almost invariably taken steps vis-à-vis troubled banks to protect all depositors from loss. Notwithstanding formal limits everywhere on the size and number of deposits insured, instances in which either small or large depositors have incurred actual losses have been rare. Similarly, although the details of intervention have varied across cases, especially in regard to the extent of any joint effort between public and private entities, governmental authorities have almost never been prepared to allow the sudden failure of an important banking institution; the 1974 collapse of the Herstatt Bank in Germany is the main significant exception.

Given this similarity in the de facto extension and operation of safety nets across major industrial countries, the moral hazard and related market discipline issues, so intensely discussed over the past year in the United States, appear to be present to some extent in all systems, even where safety net provisions have not recently been called upon. No system has in practice been fully immune from a propensity by banks to misprice their credits or become overexposed to certain high-risk borrowers, hence the broader importance of efforts to ensure the cost-effectiveness of safety nets and enhance the scope of market discipline. In addition to the renewed emphasis on capital adequacy discussed below, proposals have also included tighter limits on large or concentrated credit exposures, the use of risk-based deposit insurance premiums, depositor or other private sector co-insurance plans, prompt closure rules for troubled institutions, and restrictions on banks' asset choices. The increas- 
ingly global nature of financial markets and the resulting speed with which shocks can spread across major domestic and offshore financial centers highlights the importance of international coordination of the support efforts of major central banks.

\section{Emphasizing Capital Strength}

Previous reports in this series have provided details on the agreement on the international convergence of capital measurement and capital adequacy standards elaborated by the Basle Committee on Banking Supervision and endorsed by the Group of Ten central bank governors in July 1988. In essence, that agreement seeks to bring the recognized capital base of internationally active banks to a common minimum ratio of 8 percent of riskweighted credit exposure by the end of 1992, with transitional arrangements and an interim standard of 7.25 percent by the end of 1990 . Since its adoption, the capital adequacy accord has effectively attracted a widening group of participants. It is being implemented not only by all parties to the initial agreement (Group of Ten countries and Luxembourg) but also by virtually all countries with large international banks. For its part, the EC, in the context of its single market program, adopted directives in 1989 on bank solvency ratios and own funds that closely resemble the Basle capital accord.

The rationale for this emphasis on adequate capital has essentially been threefold. First, raising capital standards increases the proportion of a bank's risk borne by shareholders and therefore reduces the potential benefit from high-risk, high-margin investments; that is, it reduces the moral hazard problem noted above. With more of their own money at risk, bank owners and managers are likely to evaluate more prudently the risks and benefits of portfolio choices, and a higher cushion is created between potential miscalculations and the eventual need for recourse to public safety nets. Second, higher capital requirements impose an additional market test, requiring investors to be convinced that expected returns justify the commitment of risk capital. In this sense, they can also serve to promote a shrinkage of the banking sector when this test is not deemed to be met. Third, the establishment of internationally agreed capital standards aims to promote greater competitive equality across institutions from different countries (a "leveling of the playing field").

Experience to date in the application of the Basle capital accord provides the initial basis for assessing developments against these broad objectives. In practice, since the accord was announced, markets have, to a large extent, exercised their own discipline, putting pressure on major banks to achieve at least the 8 percent risk-weighted capital adequacy standard well before the end of the transitional period. Furthermore, as raising capital has become increasingly difficult and costly, banks facing capital strains have placed greater emphasis on curtailing asset growth, including outright asset sales and retrenchment from noncore activities, especially abroad. In addition, as the new capital requirements have become effective, banks have been induced to accord greater attention to their appropriate return on assets, engaging in more careful pricing for their new lending. This is perceived to be particularly the case for those institutions that were previously in a position to take advantage of relatively less binding domestic capital requirements.

All of these reactions, while seen by some as contributing to a slower expansion of credit by commercial banks, are generally considered to be salutary. The current consolidation appears to be part of a necessary slimming process that a world banking industry suffering from overcapacity needs to undergo. Market reactions to date are considered to be in line with the underlying objectives of the capital accord and are not generally viewed as warranting relaxation or delay in the application of the standards. ${ }^{13}$ The Basle Committee has for its part made it clear that it does not propose to introduce any amendments to the accord at the present juncture, and that it considers any relaxation of capital standards inappropriate.

In sum, there is a strong view among participants and officials that the domestic and international markets should and do increasingly focus on, and reward, capital strength, and that the competitive positions of internationally active financial institutions in the 1990s will hinge importantly on their comparative capital positions. Well-capitalized institutions are considered to be the best placed to establish long-term relationships, to be attractive counterparties in various financial transactions, and to expand their businesses as new market opportunities emerge.

\footnotetext{
13 This is not, however, a unanimous view; other than credit crunch considerations, the following main points are made by some observers: (a) the simplicity of the risk-weighting system (c.g., equal weight for all corporate loans) does not promote properly differentiated risk taking and could induce banks systematically to choose assets with high-risk return characteristics but low capital weights; (b) the process of securitization, prompted by the need to raise capital-to-asset ratios, often entails the sale of a bank's better quality assets, thereby reducing the average quality of its remaining portfolio; and (c) the emphasis on higher capital in an environment in which this cannot effectively be raised, and where the income positions of financial institutions are already weak, could increase the risk of a disorderly consolidation process.
} 


\section{Supervising Financial Conglomerates}

Increased competitive pressures, partly attributable to official policies of financial deregulation, have in recent years intensified the trend toward concentration, diversification, and the formation of financial conglomerates. This process raises several supervisory and regulatory challenges, including practical and technical problems relating to the identification and assessment of financial risks and to the prevention of conflicts of interest. From a more general perspective, a critical problem posed by this process is the potential extension of public safety nets to a very wide range of financial, and perhaps commercial, activity. This could result from difficulties in containing financial "contagion" across the component parts of a conglomerate. Losses in one component could reduce the prudential capital underpinning other components, or erode market confidence in the conglomerate as a whole, as occurred recently in the cases of British and Commonwealth in the United Kingdom and Drexel Burnham Lambert in the United States. If, in consequence, safety nets were perceived to extend very widely across financial markets, the efficient allocation of resources across the economy could be quite significantly affected and potential calls on budgetary resources could be substantial.

Although effective supervision and regulation can serve to limit such risks, authorities have found it difficult to isolate banking from other financial services and to abstain from intervention where sizable institutions are in difficulty. There are still in practice many unanswered questions with respect to the supervision of conglomerates. In this light, the October 1990 international conference of banking supervisors concluded that, because of the variety of structures, there is no single or simple way in which the supervision of financial conglomerates can be best carried out and that some combination of approaches is therefore necessary. ${ }^{14}$ Hence, it is through the pragmatic and flexible implementation of various supervisory tools-rather than in attempts to define a broadly valid supervisory

14 Work to refine such approaches is being pursued internationally through the efforts of the Basle Committee on Banking Supervision to develop closer working relationships between banking. securities, and insurance regulators and to establish principles for the exchange of prudential information between supervisors in different sectors and countries. Complementing such efforts. the $1983 \mathrm{EC}$ directive on the supervision of credit institutions on a consolidated basis is being revised to include financial conglomerates. model-that the issue of the supervision of financial conglomerates will most likely be addressed in practice. These complementary approaches, despite notable limitations, include specific supervisory techniques, such as consolidated supervision and supervision based on functional (rather than institutional) criteria, the isolation of particular components of groups through administrative barriers such as "firewalls" (which restrict business relations and the movement of funds within the group) and effective cooperation and information exchanges between the supervisory authorities of a group's component parts.

The difficulty of supervising effectively diversified financial conglomerates has contributed to interest in alternative policy approaches, including that of restricting tightly the assets in which deposit-taking entities may invest, that is, removing the depository function from conglomerate activity. An extreme version of this approach would create insured "narrow" banks, investing only in high-quality, short-term, liquid investments, and providing fee-based checking accounts and other payments services. Moving in such a direction would entail a significant change in current financial structures in all industrial countries. Experience over the past decade suggests that adaptive behavior in markets may, in practice, circumvent the intent of such tight balance sheet restrictions. Moreover, if narrow deposit-taking institutions were owned by a wider group, obvious questions would arise about their links to nonbank affiliates with uninsured liabilities.

As efforts continue to make supervision more effective in all of the areas discussed above, the main challenges will be to achieve greater safety without compromising competitiveness and innovativeness and without diverting financial activity to unregulated sectors. It may be necessary to accept substantial adjustment costs as excessive credit concentrations are unwound, longstanding franchises in banking are dismantled, and more rigorous pricing of credit and other risks become pervasive. Where possible, such costs should be allowed to fall on the private sector, and the changes in funding costs discussed earlier in this report illustrate the working of some market sanctions and disciplines. A critical consideration for policymakers, however, is that the current phase of transition in the national and international financial markets will be more smoothly effected if sound fiscal and monetary policies promote stable market conditions and financial confidence, and provide assurance that the budgetary underpinning of safety nets-when these are needed-is undoubted. 


\section{Recent Developments in International Capital Markets}

T his section discusses developments in 1989-90 in gross and net international capital flows through banking and securities markets, devoting special attention to the initial effects of the outbreak of the Middle East crisis on financial markets. Developments in this period illustrated both the ability of international financial markets to transmit the effects of macroeconomic and political shocks rapidly across national borders and the key role these markets have continued to play in financing the large fiscal and current account imbalances in industrial countries.

\section{Macroeconomic Environment}

The global macroeconomic context in 1990 was characterized by an uneven pattern of economic activity across major industrial countries. Although economic growth remained strong in Japan and Germany, there was a marked slowdown in North America and the United Kingdom. In addition, there was renewed concern about inflation, with upward pressure on long-term interest rates in some major industrial countries. These concerns were intensified by the sharp rise in oil prices following the outbreak of the Middle East crisis in August 1990 , although more recently interest rates have eased in a number of countries.

Short-term interest rates in the United States generally declined during 1989 and 1990 , as the pace of economic activity slowed and, by late 1990 , some easing of monetary policy was evident. U.S. long-term interest rates, however, after declining during 1989 increased during the first three quarters of 1990, reflecting renewed worries about inflation and the prospects for the U.S. fiscal deficit, then declined again in the fourth quarter. In contrast, German short- and long-term interest rates remained high as a result of concerns about the cost of financing unification, while long-term rates in Japan increased appreciably during the first three quarters of 1990, then declined in the fourth quarter. Taken together, these interest rate movements

Note: This section was prepared by Liliana Rojas-Suarez. David Folkerts-Landau, Donald J. Mathieson, Augusto de la Torre, and Rosa Vera-Bunge. brought about a reversal of differentials between the United States and other major industrial countries, with U.S. interest rates, both short- and long-term, falling below the average interest rate of the other four major industrial countries-the differential being wider at the short end of the maturity spectrum (Table A 1).

A major feature of exchange rate developments through the first three quarters of 1989 was the strength of the U.S. dollar against most other major currencies. Following a sharp decline in global equity prices in October 1989 and evidence of a widening U.S. trade deficit, the U.S. dollar weakened against major European currencies, depreciating by about 10 percent in nominal effective terms between the end of 1989 and the end of 1990. Equity prices, which in most major markets reached historic highs during 1989, registered an extended decline and, in a number of countries, an increased volatility throughout most of 1990 as fears associated with the onset of the Middle East crisis as well as negative expectations regarding inflation and recession came to the fore (Chart 5 and Table A2). The largest equity price decline among major industrial countries in 1990 occurred in Japan, where the Nikkei stock index fell by around 40 percent by year end. Following the start of military operations in the Middle East in mid-January 1991, equity prices rose sharply in all major markets; in North America and the United Kingdom, equity markets in early 1991 had recovered roughly to their levels prior to the invasion of Kuwait.

\section{Impact of the Middle East Crisis}

The response of global financial markets to the invasion of Kuwait on August 2, 1990, demonstrated the resilience of these markets and their capacity to transmit the effects of large real sector shocks rapidly across industrial and developing countries. An examination of asset price movements in spot, futures, and options markets provides an indication of the resulting adjustments in portfolios and changes in expectations concerning the future level and variability of asset prices. The initial adjustments in asset prices following the invasion suggest that the outbreak of the crisis had the following immediate effects: (1) it created the 


\section{Chart 5. Major Industrial Countries: Stock Market Indices, January 1, 1989 to January 31, 1991 \\ (Indices, August 2, $1990=100$, logarithmic scale)}
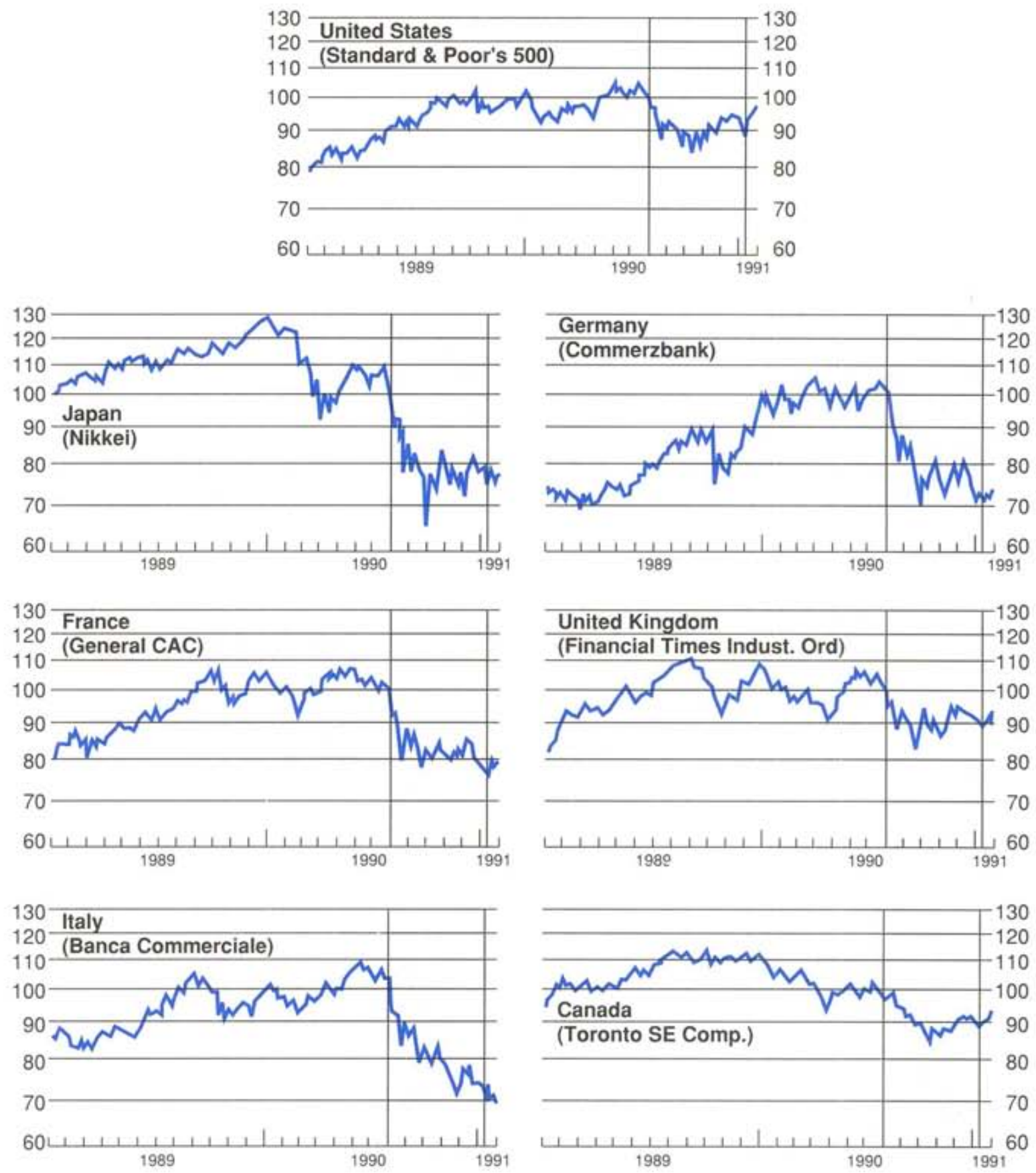

Source: Data Resources, Inc: 
perception among market participants that the prospects for many economic fundamentals (e.g., growth and inflation) had deteriorated and that the range of potentially adverse outcomes for other parameters (e.g., interest rates) had increased; (2) it produced a flight toward more liquid, short-term, and safer assets, contributing to the rapid decline in equity prices and the tightening of market conditions for less creditworthy borrowers; (3) it implied a sharp increase in the anticipated near-term variability of asset prices as reflected in options prices; and (4) its effects on financial institutions were limited primarily to some banks located in the Middle East and to banks and securities houses in industrial countries that have traditionally incorporated unrealized capital gains on asset holdings into their capital positions, or whose assets were simultaneously being affected by adverse developments in equity or real estate markets. In contrast, the response of asset prices to the outbreak of armed conflict in January 1991 was in some respects less pronounced, apart from the substantial reduction in oil prices. Nevertheless, long-term interest rates fell on both spot and futures markets and the anticipated volatility of prices for oil, bonds, and equities declined. The difference in the adjustments of asset prices in August 1990 and in January 1991 appears to have reflected the fact that the latter event was anticipated by market participants to a comparatively larger extent.

\section{Market Conditions at the Beginning of the Crisis}

During the first seven months of 1990 , prior to the invasion, asset price movements in global financial markets already reflected concerns about rising inflation and the prospect of slower economic growth in some major industrial countries. Pressure on interest rates was sustained by the continuing need to finance a number of large current account and fiscal imbalances and by the transformations underway in Germany and Eastern Europe. The period saw a general decline in equity prices (especially in Japan) from their peaks in late 1989 or early 1990. When combined with evidence of a slowdown of growth in Canada, the United Kingdom, and the United States, the weakness in equity prices and higher long-term interest rates stimulated concerns about the outlook for continued growth in world trade and output.

The emergence of the Middle East crisis intensified these concerns. Anticipated oil shortages and higher oil prices threatened to raise inflation rates and slow economic growth in many industrial and developing countries. In addition, the prospect of larger current account imbalances, which would increase the financing requirements of many coun- tries, implied possible further upward pressure on interest rates. In attempting to gauge the future economic effects of the crisis, market participants were handicapped by deep uncertainty about its political and military aspects. Moreover, the near-term outlook for major country exchange rates and shortterm interest rates was unclear, given uncertainties about the policy responses of monetary authorities in industrial countries.

\section{Initial Asset Price Effects}

Perceptions that, with the onset of the crisis, fundamental economic conditions were likely to deteriorate, but to an uncertain extent, affected a broad range of asset prices in spot, futures, and options markets. Spot and future prices for oil, equities, and long-term bonds reacted immediately. The Average Petroleum Spot Price (APSP) increased from $\$ 19.93$ a barrel during the week ended August 3, 1990 to $\$ 25.97$ for the week ended August 17, 1990. ${ }^{15}$ Futures prices rose correspondingly, with the price of West Texas crude to be delivered in September 1990, for instance, rising from $\$ 21.54$ to $\$ 28.63$ between August 1 and August 17, 1990. Equity prices, conversely, fell sharply in both industrial and developing countries. In industrial countries, the crisis accelerated the downturn in equity prices that had been evident throughout the first seven months of 1990. The decline in equity prices in the five largest industrial countries during August 1-17 was as large as that experienced during the break in equity prices on October 13, 1989 (Table A3). The decline in equity prices in many developing countries, particularly those heavily dependent on imported oil or located in the Middle East, was even more substantial than that in industrial countries (Chart 6). The secondary market prices for the external bank debt of many developing countries also declined during this period, reflecting the likely effects of higher oil prices on net oil importers as well as sales of developing country debt by banks in the Middle East with severe liquidity problems.

While short- and long-term interest rates in the major industrial countries rose during the first two weeks following the invasion, the term structure of interest rates in the spot and futures markets steepened or became less inverted. In the five largest industrial countries, for example, short-term money market rates increased by an average of 17 basis points while long-term government bond yields rose by an average of 46 basis points (Table $A 3$ and

15 The APSP is the simple average of U.K. Brent, Dubai, and Alaska North Slope crude, representing light, medium, and heavy crude oil, respectively, in the three different regions. 


\section{Chart 6. Impact of the Oil Price Rise on Developing Country Stock Markets (Percentage change in price index)}

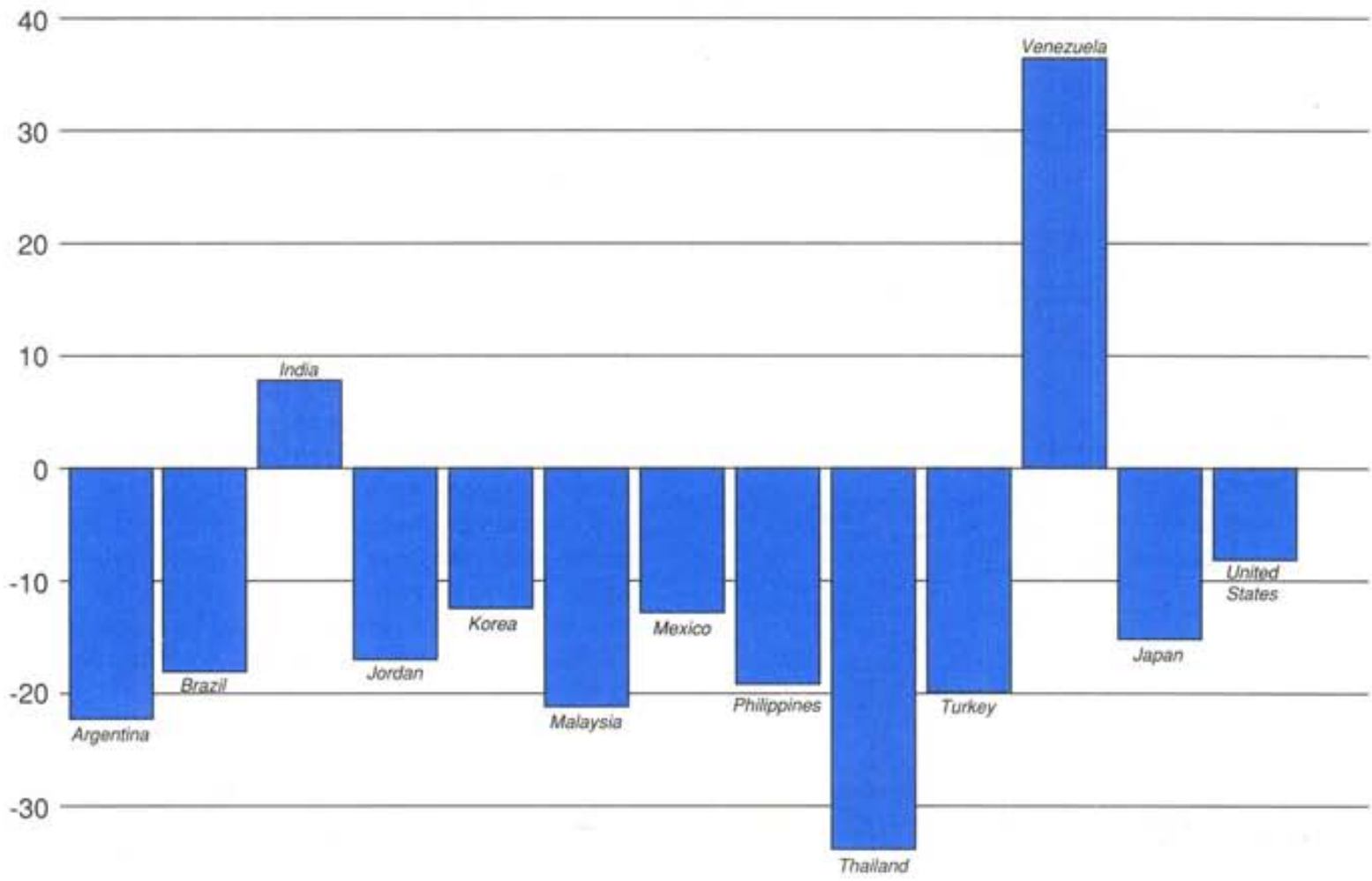

$-40$

Sources: International Finance Corporation (IFC): Emerging Markets Database.

Percentage changes in IFC's stock indices between August 3 and August 24, 1990. For Japan, the Nikkei 225 index is used; for the United States, Standard and Poor's 500 index.

Chart 7). In the futures markets for U.S. Treasury securities, the term structure of anticipated interest rates was steeper than in the spot market (Chart 8), which would be consistent with the expectation of a further rise of long-term interest rates relative to short-term rates. ${ }^{16}$ Moreover, a comparison of the term structure of interest rates for U.S. Treasury securities on the spot and futures markets indicated

16 While futures contracts now exist for long-term government bonds issued by France. Germany, Japan, the United Kingdom, and the United States, the broadest range of short-, medium- and long-term futures contracts exists for U.S. Government securities. In addition to the futures contract on the long-term U.S. Treasury bond there are also contracts on 90 day treasury bills and medium-term treasury notes. that the initial rise in short-term interest rates, at least in the United States, was expected to be reversed. ${ }^{17}$

In the foreign exchange markets, the decline of the U.S. dollar, which had been evident during much of 1990, was only momentarily interrupted by "safe haven" purchasing in the immediate wake of the crisis. During the period August 1-17, 1990, the U.S. dollar and the yen depreciated in nominal effective terms, while the deutsche mark and the

17 For example, the U.S. Treasury 90 -day bill rate stood at 7.4 percent on August 17, 1990; whereas the December 1990 U.S. Treasury bills futures contract implied a yield for December of 7.15 percent. 


\section{Chart 7. Major Industrial Countries: Interest Rates, July 1, 1990-January 31,1991 (In percent a year)}

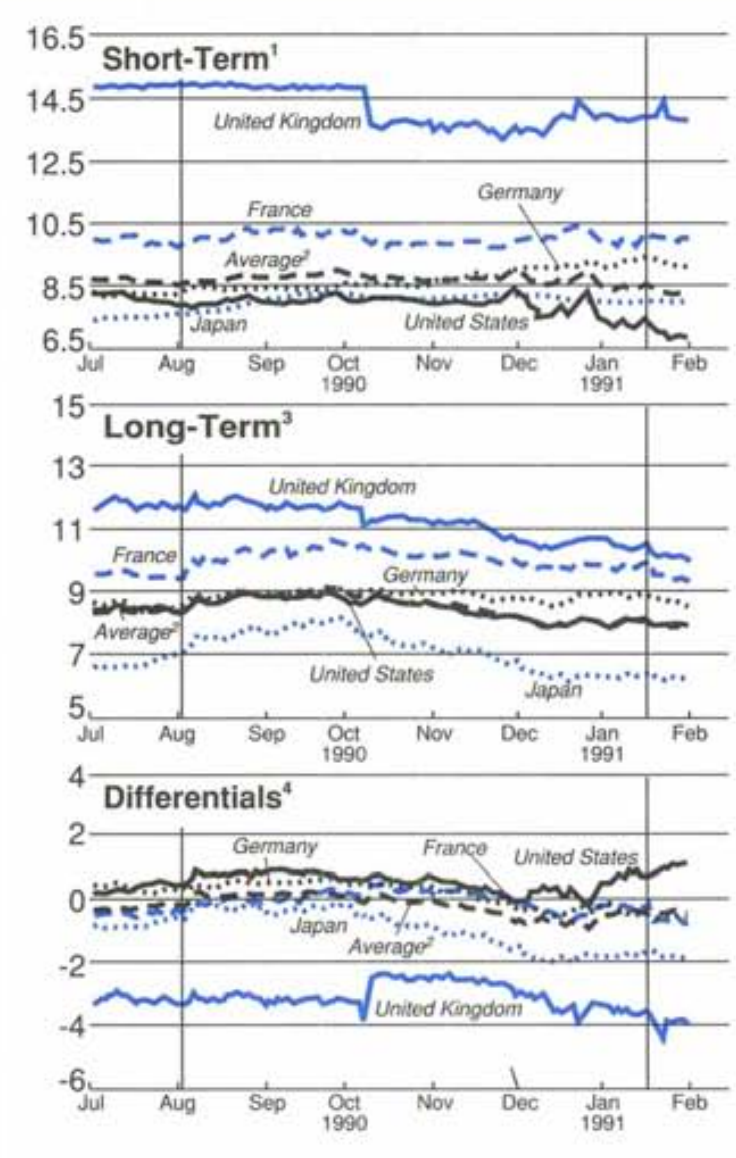

Sources: For short-term rates for United States, France, United Kingdom, and Germany, International Monetary Fund, Treasurer's Department; for Japan, Nikkei Services, Inc. For long-term rates for the United States, the Federal Reserve Board: for Germany. France, and United Kingdom, Financial Times, for Japan, Nikkei Services, Inc.

Three-month certificate of deposit rates for United States and Japan; three-month interbank deposit rates for other countries;

${ }^{2}$ Average of five countries shown, using 1989 GNP weights.

'Yields on government bonds with residual maturities of approximately ten years.

Thit is, the differences between long-term rates and short-term rates.

pound sterling appreciated. Major exchange rates showed smaller percentage changes during this period than did equity or long-term government bond prices. The price of gold, another traditional safe haven asset, increased from an average of $\$ 375$ an ounce during the week ended August 3, 1990 to $\$ 405$ an ounce during the week ended August 17, 1990.
The behavior of prices for options on oil, foreign exchange, government bonds, and equities at the beginning of the crisis implied that market participants had sharply increased their estimates of the underlying volatility of asset markets (Chart 9). ${ }^{18}$ The implicit anticipated asset price volatility in U.S. equity markets more than doubled in the two weeks following the invasion of Kuwait. The implicit volatility in the markets for U.S. Treasury bonds and Eurodollar deposits also rose sharply. Not surprisingly, the sharpest increase was in the oil markets, where the implied volatility increased almost by a factor of three. In contrast, the implied volatility in foreign exchange options did not increase significantly but was more erratic following the invasion, in part reflecting uncertainties about the policy response of monetary authorities to the crisis and the change in oil prices. More generally, the Middle East crisis appears to have stimulated the demand for derivative products that can be used to manage risk and uncertainty. Many futures and options exchanges reported record trading volumes after August 2. In August and September 1990 , for example, the total number of derivative contracts traded on the International Petroleum Exchange in London was almost triple the volume in the same period of 1989 .

The sharp declines in equity prices and long-term government bonds and the much higher implicit anticipated asset price volatility reflected in options prices suggested that market participants were concerned not only with a deterioration in fundamental economic conditions, but also with the prospect of a

18 An option gives its owner the right to buy (a call option) or sell (a put option) a financial instrument at a fixed price before or at a future date. A higher anticipated price variability of the security underlying the option will increase the price that the writer of an option will charge. The pricing models used by options writers are complex variants of the so-called BlackScholes formula for the pricing of a European-style option (which can only be exercised at the end of the option contract). This formula implies that the price of a European call option $(C)$ is given by

$$
C=P N(X)-\left[e^{-k \eta}\right] S N\left(X-s T^{-1 / 2}\right)
$$

where $P=$ the price of the underlying instrument, $S$ the price at which the option can be exercised (the strike price), $T$ the length of time until the option expires, $s$ the anticipated standard deviation of the price of the underlying instrument, $N(X)$ the standard cumulative normal probability distribution, and

$$
X=\ln \left(P / S\left[e^{-R /]}\right]\right) / s T^{1 / 2}+(1 / 2) s T^{1 / 2}
$$

Thus, the higher the anticipated volatility $(s)$ of the instrument's price, the higher the price of the option.

While this type of relationship is often used to price an option, given the option writer's estimate of the anticipated volatility, the prevailing price of the option can be used to provide an estimate of the average volatility anticipated by market participants. 


\section{Chart 8. Interest Rates Implied by Futures Contracts and Spot Rates for} U.S. Treasury Bills, Notes, and Bonds

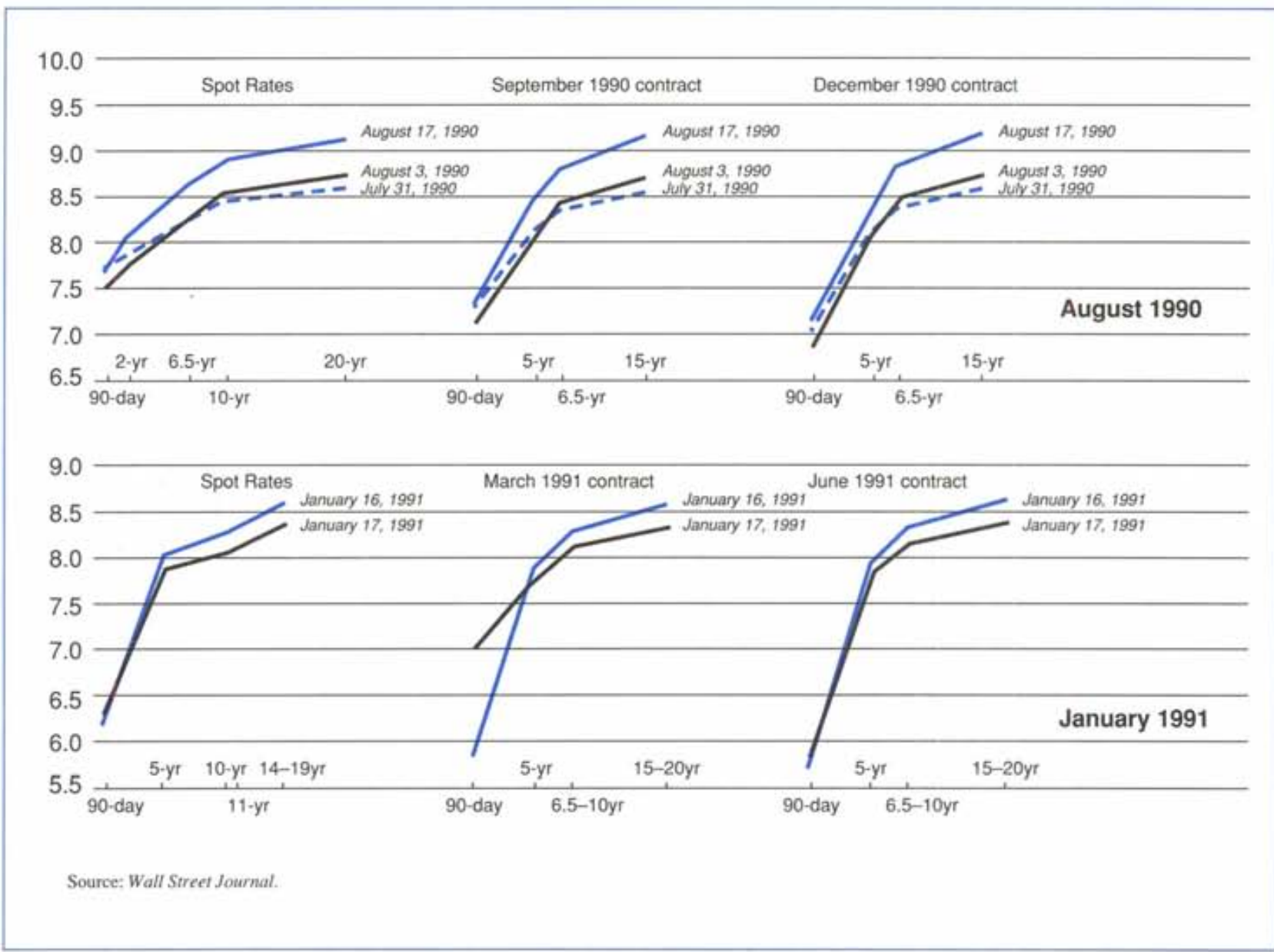

much broader range of adverse medium-term outcomes for the global economy. This abrupt change in outlook appears to have been a key reason for the differences in market behavior between the equity market breaks of October 1987 and 1989 and the crisis of August $1990 .{ }^{19}$ Although the earlier market breaks occurred on a global scale, neither was a response to a single exogenous event that presaged a sharp change in economic fundamentals. The associated "flight to quality" involved a shift in portfolio holdings away from equities and toward government securities and short-term money market instruments, and the decline in equity prices was accompanied by a fall in interest rates, especially on government securities. In August 1990, by

19 The events of October 1987 and the subsequent reform proposals are reviewed in Section V of International Monetary Fund, International Capital Markets (1989). contrast, the deterioration in the outlook for inflation and other economic variables made holding long-term and medium-term financial claims less attractive. The resulting shift in portfolio preferences toward short-term, more liquid, and safer financial instruments contributed both to the more rapid decline in equity prices and to the rise in longterm interest rates (even on government securities) relative to short-term interest rates.

\section{Effects on Institutions and Markets}

The sharp adjustment in asset prices and the increased demand for liquidity following the invasion created both direct and indirect pressures on financial institutions. While the crisis itself forced some banks in the Middle East to deal with unanticipated liquidity strains, the declines in equity prices and higher long-term interest rates eroded bank capital and created new concern about the 
Chart 9. Implied Volatility of Various Asset Prices, July 5, 1990-January 28, 1991

(In percent a year)
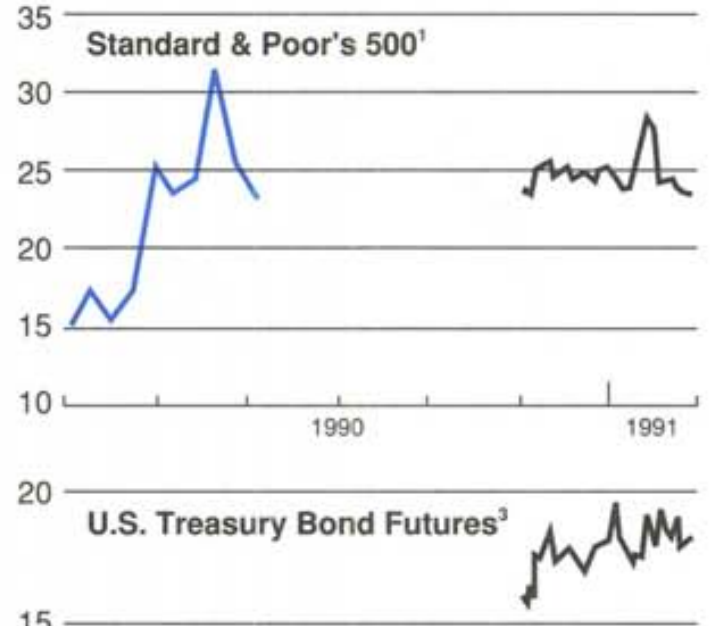

15
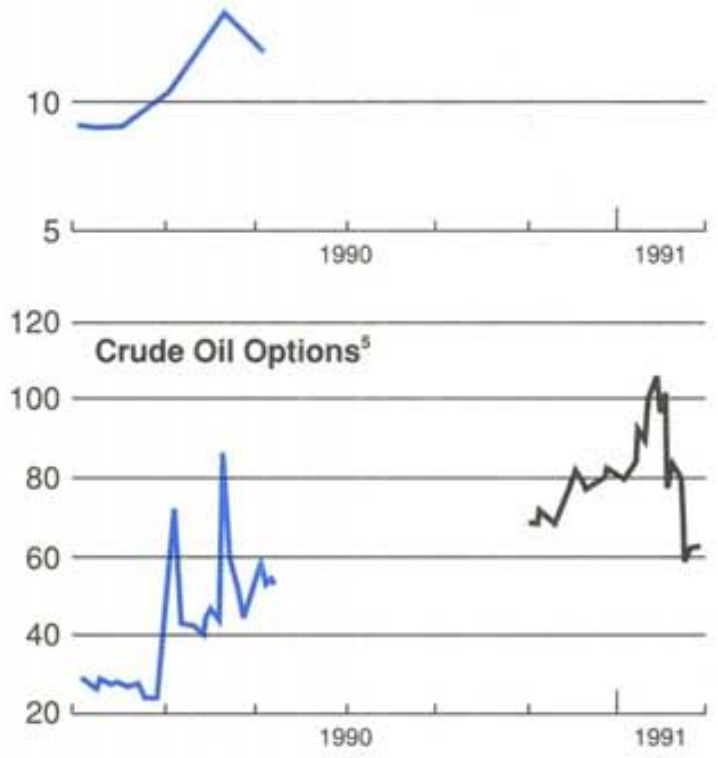
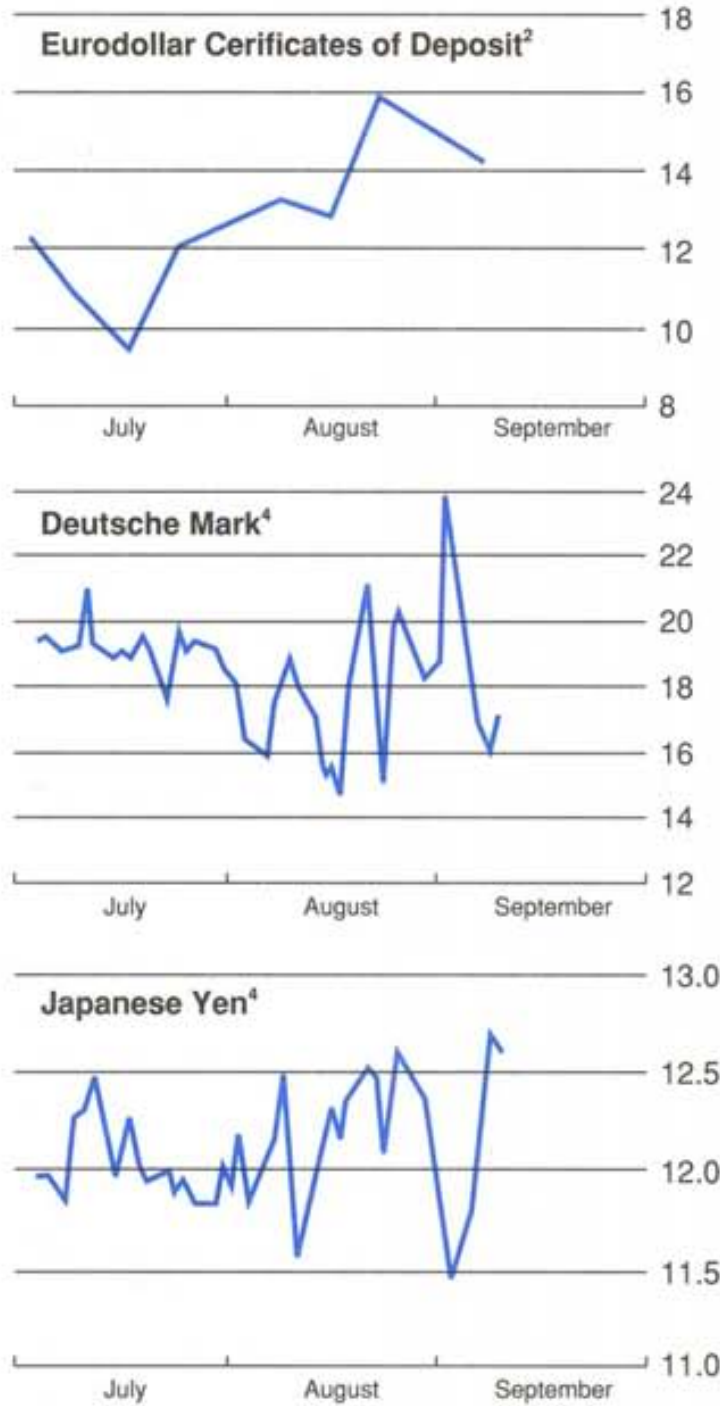

Sources: Reuters; and Salomon Brothers.

Data cover the period July 5-September 7, 1990 and December 3, 1990-January 28. 1991. The implied volatility is derived from the movements in the price of a nearby call option on a Standard \& Poor's 500 stock index futures contract.

¿ptions on 90-day nearby futures contracts. Data cover the period July 5-Septembet 7, 1990. The implied volatility is derived from movements in the price of a nearby call option on a Eurodollar certificate-of-deposit futures contract.

'Data cover the period July 5-September 7, 1990 and December 3, 1990-January 28, 1991. The implied volatility is derived from the movements in the price of a nearby call option on a U.S. Treasury bond futures contract.

Data cover the period July 5-September 7, 1990. The implied volatility is derived from the movements in the price of a foreign exchange option for a contract on the corresponding currency. The delivery date for the deutsche mark contract is June 1991.

'Data cover the period July 5-September 7, 1990 and December 3, 1990-January 28, 1991. The implied volatility for the first period is derived from movements in the price call option on a contract for New York light crude oil with a delivery date of December 1990 and a strike price of $\$ 24$ a barrel; for the second period, it is derived from the movernents in the price of a call option on a contract for New York crude oil with a delivery date of Mareh 1991 and a strike price of $\$ 30 \mathrm{a}$ barrel. 
quality of bank assets in some industrial countries. The preference for safer financial instruments also resulted in increased spreads between corporate and government securities on national markets and between private sector Eurobonds and government securities denominated in the same currency on international markets. The most immediate institutional effects of the crisis were experienced by banks located in the Middle East. Many banks in the region faced large deposit withdrawals as well as reduced lines of credit from other correspondent banks, although the extent of initial outflows was limited by the fact that many wholesale time deposits could not be withdrawn before maturity. ${ }^{20}$ Increased demands for liquidity were satisfied by extending bank business hours, selling assets, including claims on developing countries, and receiving emergency assistance from domestic monetary authorities.

Activity in international bank and bond markets fell sharply immediately after the invasion of Kuwait. Although activity in both markets recovered in September, new bond issues and loans were increasingly focused on the most creditworthy borrowers. Thus, in the United States the average return on high-yield corporate bonds, already near historically high levels relative to yields on U.S. Treasury securities because of worries about the creditworthiness of highly leveraged corporations, rose from 619 to 628 basis points over U.S. Treasury securities of comparable maturity between August 2 and August 9. Yields on Eurobonds issued by less highly regarded borrowers rose by 40 to 50 basis points relative to comparable treasury issues in early August, although yield differentials between U.S. Treasury securities and U.S. dollar denominated Eurobonds issued by highly creditworthy sovereign and multilateral borrowers did not change significantly. Borrowers with relatively low credit ratings found it more difficult to raise funds in the Eurocommercial paper market during the third quarter of 1990. Moreover, the portfolio and income difficulties of some major banks led to a widening of spreads between bank and sovereign government securities. In addition, the trend toward shorter maturities in the Eurobond market continued. Although the declines in equity prices during August 1-17 were as large as those experienced on October 13, 1989, clearance and settlement systems operated smoothly. While this in part reflected lower trading volumes in some markets, it also provided an indication of improvements in telecom-

\footnotetext{
$20 \mathrm{It}$ was also reported that the average maturity of forward foreign exchange operations between Middle East banks and other banks declined from three to six months before the crisis to only one month in early August.
}

munications and enhanced automation of the clearance and settlement systems.

In Japan, the ongoing decline in equity prices that had been evident since late December 1989 accelerated in early August 1990, with the capital positions of both securities houses and commercial banks faltering. As discussed in Section III, Japanese banks have included unrealized capital gains on their securities holdings as part of tier- 2 capital under internationally agreed capital adequacy standards. Prior to the downturn in the Japanese equity market, most large Japanese banks had capital positions that exceeded the interim capital adequacy target of 7.25 percent of risk-weighted assets (to be achieved by March 1991 in the case of Japanese banks) and many exceeded the 1993 final standard of 8 percent. The 31 percent decline in Japanese equity prices between the peak in December 1989 and midAugust eroded the size of the banks' unrealized gains. In response, Japanese banks attempted to rebuild their capital adequacy ratios largely by reducing the growth of their lending activities and by raising new tier- 2 capital through subordinated loans from domestic institutions, such as insurance companies, and the issuance of subordinated debt through offshore subsidiaries. Nevertheless, the average risk-weighted capital ratio of the major city banks declined from 8.1 percent at the end of March 1990 to 7.7 percent at the end of September 1990.

Although banks in the United Kingdom and those in the United States were not as directly affected by equity price declines as those in Japan, the prospect of higher interest rates and oil prices renewed concern about the quality of their corporate and real estate loan portfolios. During the period 1980-89, real estate loans as a percent of total commercial loans had risen from 29 percent to 37 percent for U.S. banks, and doubled to about 23 percent for U.K. banks. A downturn in real estate prices in both countries, especially for commercial property, led to an increase in nonperforming loans and a consequent rise in loan-loss provisions. In the United States, concern about bank portfolios and consequent credit downgradings led to a decline in banks' equity prices and to sharply higher costs on new subordinated debt issues. Facing an increasing cost of capital, banks focused on reducing asset growth, through direct asset sales, asset securitization, and a curtailment of lending activity.

\section{Impact of the Outbreak of Hostilities}

While the invasion of Kuwait was unanticipated by most market participants, the outbreak of hostilities in January 1991 was preceded by the establishment of a United Nations deadline for the withdrawal of Iraqi forces from Kuwait (January 15, 1991), extensive military preparations, and a vari- 
ety of diplomatic initiatives. Although uncertainty persisted, market participants had time to formulate investment and trading strategies that reflected their expectations concerning likely events. In addition, market organizations were able to prepare for the possibility of increased asset price volatility and higher trading volumes. For example, margins in a number of options and futures markets were raised in anticipation of higher asset price volatility. In addition, order transmission, clearance, and settlement systems on some major securities markets ran simulations on their computer networks to verify that they could effectively manage much heavier trading volumes. Thus, while the invasion and the subsequent outbreak of hostilities both constituted significant political shocks affecting the international economy, market participants had to respond to the August invasion more abruptly and with less information. In such a situation, asset price adjustments were, unsurprisingly, sharper and more extensive.

The outbreak of armed conflict in the Middle East on January 16, 1991 was accompanied by large declines in the prices of oil and traditional safe haven assets, a fall in long-term interest rates in most major industrial countries, a sharp increase in global equity prices, and a fall in anticipated asset price volatility across a broad range of markets. On January 17 , the spot price of oil fell by over $\$ 10$ a barrel, the largest one-day decline on record; and the price of gold fell by more than $\$ 20$ an ounce. The U.S. dollar also weakened against all other major currencies. In part, these and subsequent asset price adjustments were attributed by market participants to the early success of the coalition forces and a reduction in uncertainty regarding the expiry of the United Nations deadline. While the onset of the Middle East crisis in August had resulted in a flight toward short-term, more liquid, and safer financial instruments, the beginning of hostilities in January saw a sharp rise in equity and long-term securities prices in most major industrial countries.

On January 17 , equity prices rose by nearly 2.5 percent in London, about 4.5 percent in Japan and the United States, and by over 7 percent in France and Germany. In addition, the average level of interest rates on long-term government securities fell by 15 basis points. In the United States, movements in the prices of the March and June 1991 futures contracts for U.S. Treasury bills, notes, and bonds implied that the reduction in long-term U.S. interest rates was expected to be sustained during the first half of 1991. Sharp declines in the levels of anticipated asset price volatility implicit in options prices provided a further indication of reduced uncertainty. While the anticipated volatility of oil prices fell by about 20 percent on January 17 , there were small declines in the United States in the anticipated volatility of equity prices (as reflected in the price of an option to purchase a futures contract on the Standard and Poor's 500 stock index) and of interest rates on long-term U.S. Government bonds. Secondary market prices of the external bank debt of the most heavily indebted developing countries, which had declined in the week prior to the outbreak of hostilities, also recovered abruptly.

\section{Net International Capital Flows}

The sum of external current account deficits of the industrial countries, an indicator of the required net movement of capital through the system, increased by $\$ 10$ billion in 1989 and by $\$ 5$ billion in 1990 , to a total of $\$ 216$ billion. ${ }^{21}$ Current account imbalances in the three major industrial countries narrowed appreciably, however (Tables A4-A7). The current account deficit of the United States decreased steadily from a post-World War II peak of $\$ 162$ billion in 1987 to $\$ 100$ billion in 1990 . Japan's current account surplus also narrowed over the same period from a peak of $\$ 87$ billion in 1987 to an estimated $\$ 36$ billion in 1990. The current account surplus of Germany increased by $\$ 5$ billion to $\$ 55$ billion in 1989 , but fell back in 1990 to about $\$ 45$ billion. The net current account position (sum of surpluses and deficits) of developing countries registered a narrowing of the deficit by $\$ 1$ billion to $\$ 15$ billion during 1989 , and by a further $\$ 5$ billion in 1990, largely reflecting developments in the group of fuel exporting countries, whose current account shifted from a \$6 billion deficit in 1989 to a surplus of over $\$ 6$ billion in 1990. As in 1989, financing for the 1990 current account deficits of developing countries came principally from official creditors, while current account imbalances in the industrial countries were largely financed by private capital flows, particularly foreign direct investment and portfolio flows. This pattern of imbalances and financing suggests that, despite the rising financial needs of many Eastern European and developing countries, most net transfers of saving across borders continue to occur within the group of industrial countries.

Analysis of the recent evolution of net capital flows in major industrial countries is complicated by large "errors and omissions" in the balance of payments of a number of these countries. With this proviso, the remainder of this section provides a review of recent net capital flows in the three main industrial countries.

21 For a detailed discussion of recent macroeconomic devel. opments, see International Monetary Fund, World Economic Outlook (1991). 


\section{United States}

During 1989 , in sharp contrast to the three preceding years and reflecting substantial official intervention in currency markets, there was a large buildup ( $\$ 25$ billion) of net official reserves. Although net official reserves continued to increase during the first quarter of 1990 , they declined during the second and, in particular, third quarter of 1990 , mirroring an increase in the current account deficit. Net foreign direct investment into the United States, which had reached an average of \$41 billion a year in 1988-89, largely owing to crossborder mergers and acquisitions activity, turned into a net outflow of over $\$ 17$ billion during the first three quarters of 1990 , owing both to a marked decline in inward flows and to the continued strength of U.S. direct investment abroad.

After taking into account the accumulation of net foreign reserves and net flows of direct foreign investment, the residual current account financing needs in 1989 (about $\$ 87$ billion) were mostly met by portfolio inflows, mainly in the form of purchases of U.S. Government securities by nonresidents. In contrast, during the first three quarters of 1990 , there was a net outflow of nearly $\$ 18$ billion through the securities markets, reflecting worry about the weakening U.S. economy, problems in the domestic financial sector, and a significant reduction in interest rate differentials in favor of U.S. dollar-denominated assets. In particular, foreign purchases of U.S. Treasury bonds declined sharply from $\$ 30$ billion in the first three quarters of 1989 to less than $\$ 2$ billion in the first three quarters of 1990; over the same period $\$ 3$ billion net purchases of U.S. corporate securities by foreigners gave way to net sales of $\$ 19$ billion. As a result, residual current account financing needs in the first three quarters of 1990 (about $\$ 78$ billion) were largely covered by unidentified flows (errors and omissions), possibly involving Eurodollar market transactions, and by an increase in short-term inflows through the banking system in the third quarter.

\section{Japan}

A decline of $\$ 13$ billion in Japanese official reserves during 1989 seems to have been largely due to official intervention in support of the yen. As downward pressure on the yen continued during the earlier part of 1990, the authorities seem to have intervened further, and a decline in official reserves by $\$ 10$ billion could be mainly attributed to these operations. During 1989-90, Japanese direct investment abroad continued to expand strongly, at an annual rate of $\$ 45-50$ billion. Direct investment in the United States, however, which accounted for more than half of Japan's total direct investment in the $1985-88$ period, began slowing in 1989 as Japanese residents increased their activities in Europe. The rest of Japan's direct investment abroad was directed mainly toward Asian countries.

Although net portfolio investments abroad declined sharply by $\$ 20$ billion to $\$ 33$ billion in 1989 , both assets and liabilities expanded significantly during the year. The sustained two-way flow of portfolio capital reflected, inter alia, the continued strong interest of Japanese financial institutions in foreign securities, remaining rigidities in Japanese capital markets that encourage domestic firms to seek funding in international capital markets, and the fact that many bonds issued abroad by Japanese corporations are bought by Japanese investors. Such bond issues-most with equity warrantsdeclined sharply at the beginning of 1990 , following the decline in prices on the Tokyo Stock Exchange. This was a key factor behind the net portfolio outflow of $\$ 17$ billion during the first half of 1990 .

Net inflows from the banking sector declined by $\$ 35$ billion to $\$ 4$ billion during 1989 and shifted to a net outflow in the first half of 1990 . The fall was partly associated with a reduction in the proportion of foreign portfolio investments that were hedged by forward currency contracts with banks, which in turn may have reflected changes in exchange rate expectations. In addition, net long-term bank outflows declined because of increased borrowing by Japanese residents after restrictions on long-term Euro-yen lending were eased in May 1989.

\section{Germany}

The net external position of German monetary authorities fell by $\$ 11$ billion during 1989 as the acquisition of German liabilities by foreign monetary authorities-particularly the United Statesmore than offset a rise in the foreign reserves of the Deutsche Bundesbank. Net official reserves increased, however, by about $\$ 4$ billion in the first three quarters of 1990. An important feature of developments in 1989 was a sharp decline of net outflows through securities markets, which fell by $\$ 39$ billion to $\$ 4$ billion. This reflected a number of factors, including the announcement in April of the abolition of withholding taxes on interest earnings, the narrowing of international interest rate differentials, and favorable expectations concerning unification. During the first three quarters of 1990 , however, partly reflecting unsettled equity markets and new concerns about the budgetary implications of unification, net portfolio outflows increased significantly, even as the current account surplus began to narrow. Largely offsetting these outflows was a simultaneous decline in outflows from the banking 
sector. At the same time, German direct investment abroad, mainly to countries in the EC, rose appreciably.

\section{Gross International Financial Flows}

While the level of net international capital flows remained relatively unchanged between 1989 and 1990 , the deterioration in the macroeconomic environment and increased uncertainty about asset price developments led to a significant decline in the scale of gross capital flows and in activity in some major segments of international financial markets. After a sharp contraction in 1988, international banking activity recovered during 1989 (Chart 10). Gross flows continued to be concentrated in the industrial countries but, in contrast to previous years, the expansion reflected the growth of international banking activities in Western European countries, rather than in the United States and Japan. International bank lending to borrowers in industrial countries, which accounted for 69 percent of total cross-border lending in 1989 , increased by $\$ 93$ billion that year, while deposit-taking from entities in industrial countries expanded by $\$ 203$ billion (Table 4). As in previous years, the bulk of international banking flows represented interbank activity (Table A8). In terms of growth rates, however, interbank lending to industrial countries increased by 10 percent in 1989 , while lending to nonbank entities in industrial countries expanded by 75 percent (Table A9). Much of the growth in the latter category was associated with mergers and acquisitions, especially in the United States and the United Kingdom, and with increased activity in securities and derivative products markets.

In 1990, international banking flows declined abruptly during the first half of the year before registering a partial recovery in the third quarter. Overall, however, the growth of cross-border lending to industrial countries fell by $\$ 27$ billion in the first three quarters of 1990 relative to the corresponding period of 1989, while the expansion of deposittaking from industrial countries fell by $\$ 89$ billion. Interbank business slowed substantially, most notably in the United States and Japan. Bank claims on developing countries, which increased by $\$ 11$ billion in 1989, declined by $\$ 13$ billion in the first three quarters of 1990 (Tables A10-A13). Reductions in banks' claims on the 15 heavily indebted countries more than offset an increase in claims on other developing countries. ${ }^{22}$ Together with signifi-

22 A fuller discussion of developing country access to spontaneous bank lending is found in Section $\mathrm{V}$ of this paper, while bank debt restructurings are covered in Section VI.
Chart 10. Growth Rate of International

Bank Claims, 1982-Third Quarter 1990

(Twelve-month growth rates; in percent)

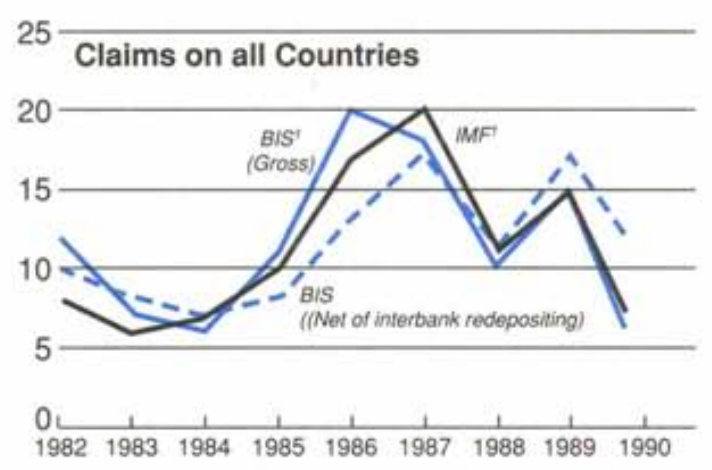

20

Claims on Developing Countries

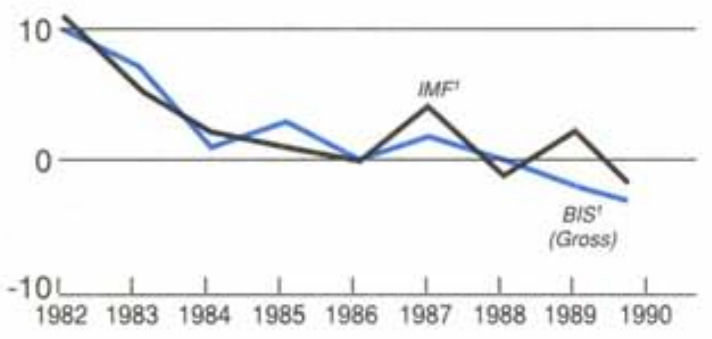

Sources; Bank for International Settlements, International Banking and Financial Market Developments; International Monetary Fund, International Banking Statistics and International Financial Statistics; and Fund staff estimates.

'These data do not net out interbank redepositing.

cant increases in deposit-taking, this meant that developing countries remained net providers of funds to the international banking sector, a pattern which began in 1987 .

International bond markets continued to expand during 1989, albeit at a slower pace (Tables 5 and A14 and A15). New issues of international bonds reached $\$ 256$ billion in 1989 , a 13 percent increase over the previous year, mainly due to a $\$ 40$ billion expansion in equity-related bonds issued by Japanese borrowers (Table A16). The growth in those types of bonds more than offset a decline in new issues in other sectors of the bond market, especially in the U.S. high-yield ("junk") bond market. During 1990, in contrast, new issues declined by 11 percent to $\$ 229$ billion, mainly due to the sharp contraction in equity-related bonds following weak- 
Table 4. Change in Cross-Border Bank Claims and Liabilities, 1984-Third Quarter 19901 (In billions of U.S. dollars)

\begin{tabular}{|c|c|c|c|c|c|c|c|c|}
\hline & \multirow[b]{2}{*}{1984} & \multirow[b]{2}{*}{1985} & \multirow[b]{2}{*}{1986} & \multirow[b]{2}{*}{1987} & \multirow[b]{2}{*}{1988} & \multirow[b]{2}{*}{1989} & 1989 & 1990 \\
\hline & & & & & & & \multicolumn{2}{|c|}{$\begin{array}{c}\text { First } \\
\text { three quarters }\end{array}$} \\
\hline Total change in claims ${ }^{2}$ & 183 & 276 & 538 & 803 & 559 & 820 & 581 & 432 \\
\hline Industrial countries & 132 & 208 & 413 & 548 & 471 & 564 & 413 & 386 \\
\hline $\begin{array}{l}\text { United States } \\
\text { Unith: }\end{array}$ & 36 & 55 & 93 & 106 & 108 & 93 & 60 & 32 \\
\hline Japan & 20 & 40 & 154 & 223 & 202 & 173 & 125 & 66 \\
\hline Developing countries $^{3}$ & 11 & 4 & 2 & 22 & -6 & 11 & 6 & -13 \\
\hline Offshore centers ${ }^{4}$ & 29 & 28 & 86 & 164 & 85 & 181 & 115 & 41 \\
\hline Other transactors 5 & 6 & 10 & -7 & 19 & 6 & 34 & 30 & -11 \\
\hline Unallocated (nonbanks) ${ }^{6}$ & 5 & 26 & 43 & 50 & 4 & 29 & 17 & 28 \\
\hline \multicolumn{9}{|l|}{ Memorandum items } \\
\hline Capital importing developing countries ${ }^{3.7}$ & 13 & 5 & 3 & 21 & -10 & 6 & 5 & -8 \\
\hline Non-oil developing countries 3.8 & 14 & 3 & 3 & 22 & -11 & 7 & 6 & -8 \\
\hline Fifteen heavily indebted countries & 6 & -6 & -1 & 2 & -15 & -2 & -2 & -27 \\
\hline Total change in liabilities ${ }^{9}$ & 186 & 302 & 584 & 762 & 541 & 801 & 565 & 387 \\
\hline Industrial countries & 118 & 194 & 424 & 494 & 370 & 573 & 419 & 330 \\
\hline \multicolumn{9}{|l|}{ Of which: } \\
\hline United States & 8 & 22 & 82 & 57 & 84 & 67 & 41 & -36 \\
\hline Japan & 12 & 42 & 114 & 146 & 148 & 138 & 113 & 29 \\
\hline Developing countries $^{3}$ & 24 & 23 & -7 & 47 & 37 & 69 & 39 & 50 \\
\hline Offshore centers ${ }^{4}$ & 24 & 46 & 130 & 145 & 100 & 148 & 88 & -11 \\
\hline Other transactors 5 & 2 & 8 & -6 & 18 & 6 & 13 & 15 & -15 \\
\hline Unallocated (nonbanks) 6 & 18 & 31 & 42 & 58 & 28 & 2 & 4 & 33 \\
\hline \multicolumn{9}{|l|}{ Memorandum items } \\
\hline Capital importing developing countries ${ }^{3.7}$ & 25 & 21 & 8 & 36 & 25 & 58 & 34 & 54 \\
\hline Non-oil developing countries ${ }^{3.8}$ & 23 & 16 & 16 & 36 & 25 & 52 & 31 & 50 \\
\hline Fifteen heavily indebted countries & 15 & 5 & -4 & 10 & 5 & 17 & 13 & 16 \\
\hline Change in total net claims 10 & -2 & -26 & -45 & 41 & 19 & 9 & 15 & 45 \\
\hline Industrial countries & 14 & 13 & -11 & 55 & 100 & -8 & -6 & 56 \\
\hline \multicolumn{9}{|l|}{ Of which: } \\
\hline United States & 28 & 33 & 12 & 49 & 24 & 26 & 19 & 68 \\
\hline Japan & 8 & -2 & 40 & 77 & 54 & 35 & 12 & 37 \\
\hline Developing countries ${ }^{3}$ & -12 & -19 & 9 & -25 & -43 & -58 & -32 & -62 \\
\hline Offshore centers 4 & 5 & -17 & -45 & 20 & -16 & 33 & 27 & 53 \\
\hline Other transactors 5 & 5 & 2 & -1 & 1 & - & 21 & 14 & 4 \\
\hline Unallocated (nonbanks) & -14 & -5 & $i$ & -8 & -24 & 31 & 12 & -5 \\
\hline \multicolumn{9}{|l|}{ Memorandum items } \\
\hline Capital importing developing countries ${ }^{3,7}$ & -13 & -16 & -5 & -15 & -36 & -51 & -28 & -62 \\
\hline Non-oil developing countries ${ }^{3.8}$ & -9 & 13 & -13 & -15 & -37 & -45 & -25 & -58 \\
\hline Fifteen heavily indebted countries & -9 & -10 & 3 & -7 & -20 & -19 & -14 & -43 \\
\hline
\end{tabular}

Sources: International Monetary Fund, International Financial Statistics (IFS): and Fund staff estimates.

'Data on changes in bank claims and liabilities are derived from stock data on the reporting countries' liabilities and assets, excluding changes attributed to exchange rate movements.

${ }^{2}$ As measured by differences in the outstanding liabilities of borrowing countries defined as cross-border interbank accounts by residence of borrowing bank plus international bank credits to nonbanks by residence of borrower.

'Excluding offshore centers.

"Consisting of The Bahamas, Bahrain, the Cayman Islands, Hong Kong, the Netherlands Antilles, Panama, and Singapore.

"Transactors included in IFS measures for the world, to enhance global symmetry, but excluded from IFS measures for "All Countries." The data comprise changes in identified cross-border bank accounts of centrally planned economies (excluding Fund members) and of international organizations.

'Calculated as the difference between the amount that countries report as their banks' positions with nonresident nonbanks in their monetary statistics and the amounts that banks in major financial centers report as their positions with nonbanks in each country.

'Consisting of all developing countries except the eight Middle Eastern oil exporters (the Islamic Republic of Iran, Iraq. Kuwait, the Libyan Arab Jamahiriya, Oman, Qatar, Saudi Arabia, and the United Arab Emirates) for which external debt statistics are not available or are small in relation to external assets.

"Consisting of all developing countries except the eight Middle Eastern oil exporters (listed in footnote 7), Algeria, Indonesia, Nigeria, and Venezuela.

TAs measured by differences in the outstanding assets of depositing countries, defined as cross-border interbank accounts by residence of lending bank plus international bank deposits of nonbanks by residence of depositor.

10Difference between changes in bank claims and liabilities. 
Table 5. Developments in International Bond Markets, 1983-90

\begin{tabular}{|c|c|c|c|c|c|c|c|c|c|}
\hline & & & & & & & & & 1990 \\
\hline & 1983 & 1984 & 1985 & 1986 & 1987 & 1988 & 1989 & 1990 & $\begin{array}{l}\text { First three } \\
\text { quarters }\end{array}$ \\
\hline & \multicolumn{9}{|c|}{ (In billions of U.S. dollars) } \\
\hline Total gross international bonds & 77 & 110 & 168 & 227 & 181 & 227 & 256 & 229 & 172 \\
\hline Amortization & 18 & 20 & 36 & 64 & 76 & 83 & 90 & 111 & 78 \\
\hline Net issues' & 59 & 90 & 132 & 163 & 105 & 144 & 166 & 118 & 94 \\
\hline Bond purchases by banks & 13 & 28 & 55 & 76 & 53 & 67 & 68 & $\ldots$ & 64 \\
\hline $\begin{array}{l}\text { Net issues less bond } \\
\text { purchases by banks } \\
\text { Of which: }\end{array}$ & 46 & 62 & 77 & 87 & 51 & 77 & 98 & $\cdots$ & 30 \\
\hline Industrial countries & 36 & 51 & 63 & 77 & 44 & 67 & 81 & $\ldots$ & 25 \\
\hline Developing countries & 2 & 3 & 4 & 2 & I & 2 & 2 & $\ldots$ & 1 \\
\hline \multicolumn{10}{|l|}{ By category of borrower } \\
\hline Industrial countries & 60 & 91 & 137 & 200 & 156 & 198 & 224 & 189 & 143 \\
\hline Developing countries & 3 & 5 & 10 & 5 & 4 & 6 & 5 & 5 & 4 \\
\hline \multirow{3}{*}{$\begin{array}{l}\text { Other, including inter- } \\
\text { national organizations }\end{array}$} & & & & & & & & & \\
\hline & 14 & 13 & 21 & 21 & 21 & 23 & 27 & 35 & 25 \\
\hline & \multicolumn{9}{|c|}{ (In percent) } \\
\hline By currency of denomination & & & & & & & & & \\
\hline U.S. dollar & 57 & 64 & 61 & 55 & 36 & 37 & 50 & 34 & 37 \\
\hline Deutsche mark & 9 & 6 & 7 & 8 & 8 & 10 & 6 & 8 & 9 \\
\hline Swiss franc & 18 & 12 & 9 & 10 & 13 & 12 & 7 & 10 & 10 \\
\hline Japanese yen & 5 & 6 & 8 & 10 & 15 & 10 & 9 & 14 & 12 \\
\hline $\mathrm{Ecu}^{2}$ & 3 & 3 & 4 & 3 & 4 & 5 & 5 & 9 & 9 \\
\hline \multirow[t]{2}{*}{ Other } & 8 & 9 & 11 & 14 & 24 & 26 & 23 & 25 & 24 \\
\hline & \multicolumn{9}{|c|}{ (In percent a year) } \\
\hline \multicolumn{10}{|l|}{ Interest rates } \\
\hline Eurodollar deposits ${ }^{3}$ & 10.1 & 9.0 & 8.0 & 6.3 & 7.9 & 9.4 & 8.4 & 7.9 & 8.1 \\
\hline Dollar Eurobonds ${ }^{4}$ & 12.5 & 12.1 & 10.6 & 8.6 & 10.2 & 9.7 & 8.7 & 9.1 & 9.4 \\
\hline Deutsche mark international bonds ${ }^{4}$ & 8.4 & 7.4 & 6.9 & 6.6 & 6.5 & 6.2 & 7.9 & 9.6 & 9.5 \\
\hline \multicolumn{10}{|c|}{$\begin{array}{l}\text { Sources: Organization for Economic Cooperation and Development, Financial Statistics Monthly and Financial Market Trends; Bank for } \\
\text { International Settlements, International Banking and Financial Market Developments; and Fund staff estimates. } \\
\text { 'Gross issues less scheduled repayments and early redemption. } \\
\text { 'European currency unit. } \\
\text { 3Three-month deposits, at end of period. } \\
\text { 'Bonds with remaining maturity of } 7-15 \text { years, at end of period. }\end{array}$} \\
\hline
\end{tabular}

ness in the Tokyo stock market. While issues of fixed rate bonds remained practically unchanged (at around $\$ 155-160$ billion) in 1989-90, interest rate uncertainties contributed to a doubling in the issuance of floating rate notes to $\$ 37$ billion in 1990 (Tables A17 and A18). More generally, during the year, and particularly after the outbreak of the Middle East crisis, investors' preferences shifted toward short-term instruments, including Eurocommercial paper, and toward high-quality issuers, especially sovereign or supranational entities.

As in previous years, borrowers from industrial countries dominated international bond markets (Chart 11). During 1989-90, about 85 percent of total issues were by industrial country borrowers, while the share of borrowers from developing countries declined from about 3 percent in 1988 to about 2 percent in 1989, before increasing slightly in
$1990 .{ }^{23}$ In terms of the currency composition of new international bond issues, U.S. dollardenominated bonds increased from 37 percent in 1988 to 50 percent in 1989 before falling back to 34 percent in 1990 (Chart 12). In part, this reflected a reversal of interest rate differentials between the United States and other major industrial countries. The composition of instruments traded in bond markets also shifted significantly during 1989-90. The share of fixed interest rate bonds, which had risen continuously between $1985-88$, declined by a sharp 10 percent in 1989 before recovering in 1990 (Table A 19). Issues of floating rate notes continued to decline during 1989 as well, as had been the case

${ }^{23}$ A discussion of developing country access to bond markets is found in Section V. 


\section{Chart 11. International Bond Issues by Groups of Borrowers, 1985-90 (In percent)}

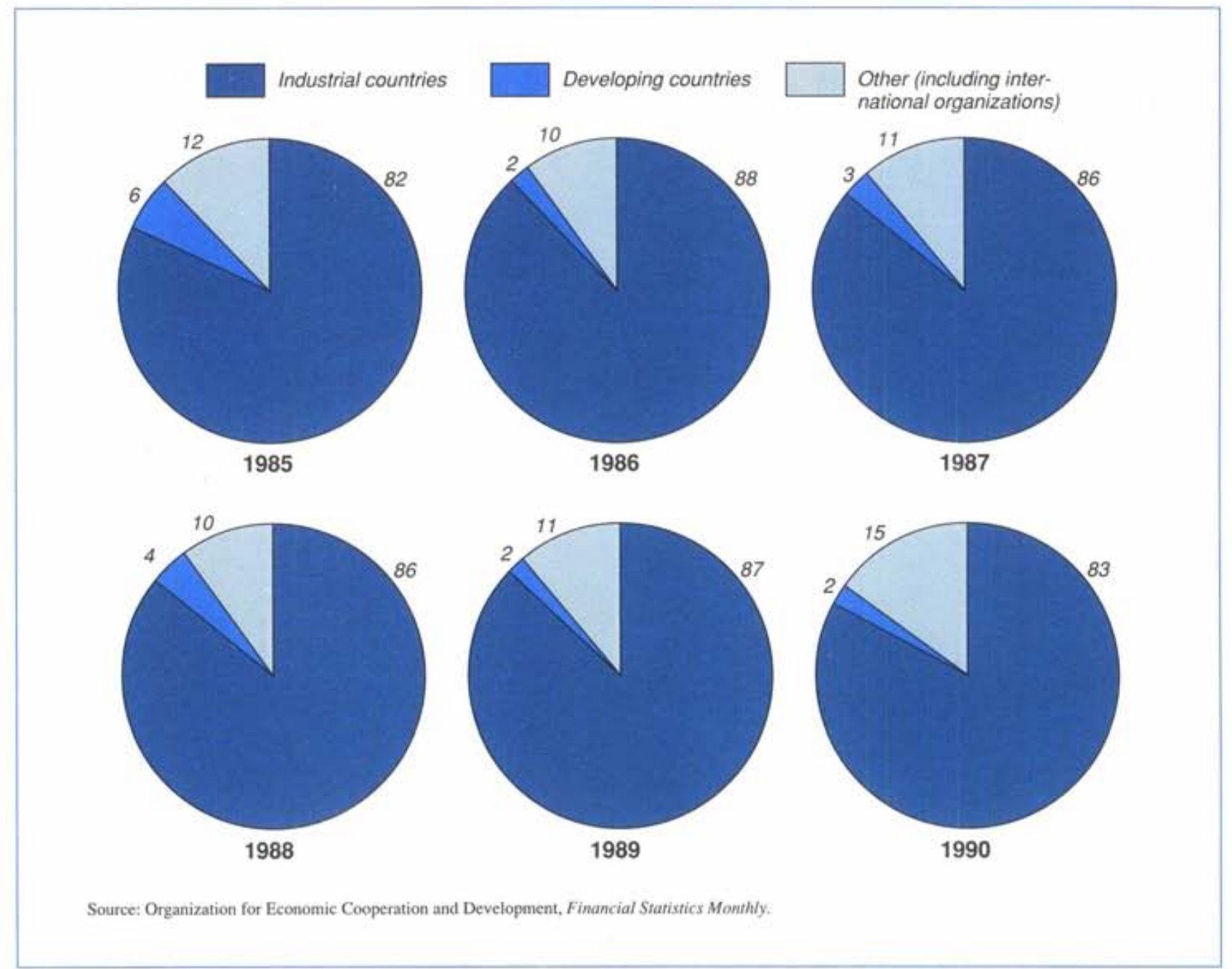

since the collapse of the market for perpetual floating rate notes in December 1986. In 1989, floating rate notes accounted for only 7 percent of total issues, compared with 35 percent in 1985. In 1990, however, that share rose to 16 percent. Correspondingly, the share of equity-related bonds, which had declined during 1988 as a consequence of the stock market break in October 1987, recovered sharply during 1989 on the strength of the Tokyo Stock Exchange, reaching a peak of 31 percent of total bond issues before reverse developments pushed it down to 13 percent in 1990.

During 1989-90, international equity markets continued the strong expansion that had been evident since the early 1980 s (Table A20). The value of international equity trading expanded by 26 percent during 1989 to $\$ 1.5$ trillion while its volume rose by 10 percent (Table 6). The expansion was in part related to favorable expectations about the economic prospects associated with the changes in Eastern Europe and progress toward the creation of a single EC market. It also highlighted deepening financial interdependence, as increased arbitrage activities led to a narrowed spread of valuations across national and international equity markets.

Primary issuance in international equity markets (excluding issues of bonds with equity warrants) rose by $\$ 7$ billion in 1989 , with the major share of growth occurring in ordinary, nonconvertible, shares (Table 7). Data for the first half of 1990 point to a further significant growth in the issuance of ordinary shares. As regards the composition of gross equity flows (purchases plus sales of equity), investors from the United Kingdom were, as in pre- 


\section{Chart 12. Currency Composition of International Bond Issues, 1985-901} (In percent)

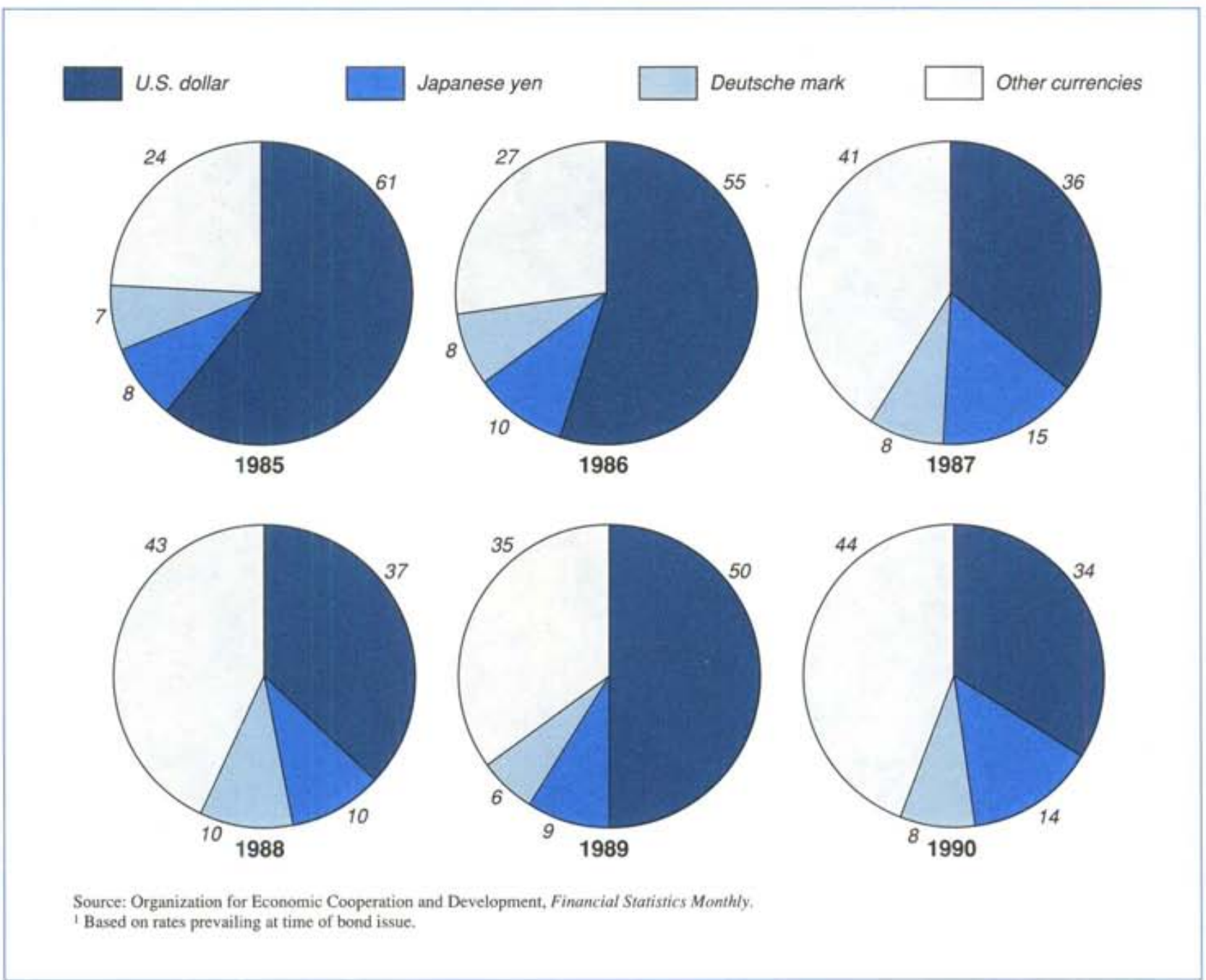

vious years, the most active traders in international equity markets in 1989 ( 20 percent of the total), although Japanese investors were the most active early in 1990 . Of the total foreign equity trading by Japanese investors during 1989 , over 30 percent involved U.S. securities, in sharp contrast to previous years, when the share had been in the range of 80 percent. Investors from the United States continued to concentrate their foreign equity trading on securities from the United Kingdom and Japan. Reflecting favorable expectations on German unification, trading in German equities increased sharply from $\$ 61$ billion in 1988 to $\$ 109$ billion in 1989 , an expansion that continued during the first quarter of 1990, when the trading value in German shares tripled relative to the first quarter of 1989.
Net equity flows (purchases minus sales of equity) also expanded sharply during 1989 to $\$ 92$ billion, a record high (Table A21). The sharpest increase (by $\$ 29$ billion) was in net purchases by foreigners of European equities, particularly from Germany. Data for the first quarter of 1990 indicate further strong increases in net foreign purchases of European equities and substantial net sales of Japanese equities. International mergers and acquisitions activity continued to be an important source of net equity flows, although its rate of increase slowed substantially during 1989 ( 7 percent as compared with a compound annual average of 67 percent in the 1986-88 period (Table A22)). The United States, which had been the target country for about 70 percent of all international mergers and 
Table 6. Equity Markets: Secondary Trading Values and Volumes, 1979-89 (In billions of U.S. dollars)

\begin{tabular}{|c|c|c|c|c|c|}
\hline & \multirow{2}{*}{$\begin{array}{l}\text { Total World } \\
\text { Trading } \\
\text { Value }\end{array}$} & \multicolumn{4}{|c|}{ International Equity Markets } \\
\hline & & $\begin{array}{c}\text { Trading } \\
\text { value }\end{array}$ & $\begin{array}{l}\text { Percentage } \\
\text { change }\end{array}$ & Volume' & $\begin{array}{c}\text { Percentage } \\
\text { change }\end{array}$ \\
\hline 1979 & $\cdots$ & 73.1 & & 100.0 & \\
\hline 1980 & $\ldots$ & 120.4 & 64.7 & 135.7 & 35.7 \\
\hline 1981 & $\ldots$ & 149.4 & 24.1 & 182.9 & 34.8 \\
\hline 1982 & $\ldots$ & 151.6 & 1.5 & 175.3 & -4.2 \\
\hline 1983 & $\ldots$ & 272.0 & 79.4 & 265.7 & 51.6 \\
\hline 1984 & $\ldots$ & 296.9 & 9.2 & 284.6 & 7.1 \\
\hline 1985 & $\ldots$ & 385.2 & 29.7 & 276.5 & -2.9 \\
\hline 1986 & $7,024.6$ & 800.8 & 107.9 & 402.8 & 45.7 \\
\hline 1987 & $11,551.6$ & $1,344.4$ & 67.9 & 591.4 & 46.8 \\
\hline 1988 & $10,598.9$ & $1,212.6$ & -9.8 & 440.1 & -25.6 \\
\hline 1989 & $11,716.9$ & $1,528.3$ & 26.0 & 483.4 & 9.8 \\
\hline
\end{tabular}

Table 7. International Equity Markets-Primary Issuance, 1986-89 (In billions of U.S. dollars)

\begin{tabular}{|c|c|c|c|c|c|c|}
\hline & & & & & 1989 & 1990 \\
\hline & 1986 & 1987 & 1988 & 1989 & \multicolumn{2}{|c|}{ First half } \\
\hline Convertibles & 6.5 & 14.2 & 5.8 & 5.3 & 3.9 & 2.8 \\
\hline \multirow{2}{*}{$\begin{array}{l}\text { Ordinary shares } \\
\text { Of which: } \\
\text { Privatization }\end{array}$} & 11.6 & 20.3 & 9.1 & 16.7 & 5.9 & 7.9 \\
\hline & 1.1 & 7.7 & 2.1 & 3.6 & $\ldots$ & $\ldots$ \\
\hline Total & 18.1 & 34.5 & 14.9 & 22.0 & 9.6 & 10.7 \\
\hline \multicolumn{7}{|l|}{ Memorandum item } \\
\hline $\begin{array}{l}\text { Bonds with equity warrants } \\
\text { Of which: }\end{array}$ & 15.2 & 23.5 & 28.5 & 67.1 & $\ldots$ & $\ldots$ \\
\hline By Japanese borrowers & $\cdots$ & $\ldots$ & $\ldots$ & $\ldots$ & 41.4 & 6.3 \\
\hline
\end{tabular}

acquisitions in 1986-88, accounted for 50 percent of them in 1989 and for only 35 percent in the first half of 1990. By contrast, foreign funds into the United Kingdom and countries in continental Europe rose during 1989 and the first half of 1990 , increasing their share in international mergers and acquisitions to over 50 percent.

\section{Markets for Derivative Products}

Trading activity in derivatives markets continued to expand in 1989-90, a trend that had been evident since the early $1980 \mathrm{~s}$, as volatility in asset prices, technological developments, and competition between exchanges continued to foster hedging and speculative activities. The Middle East crisis, as noted, contributed to a further sharp expansion in derivative products trading in 1990 (Table A23).

The range of derivative products publicly traded on organized exchanges also increased significantly during 1989-90. In April 1989, the London International Financial Futures Exchange (LIFFE) and the Marché à Terme d'Instruments Financiers (MATIF) introduced futures contracts on the threemonth Euro-deutsche mark interest rate. In October 1990 , the MATIF introduced an ECU bond futures contract, and LIFFE launched a similar contract in March 1991. The contract will complement the existing three-month ECU interest rate contract, which started trading on LIFFE in 1989, and will allow users to hedge both the long and short ends of 
the ECU yield curve. In late 1990, the Deutsche Terminbörse (DTB) in Frankfurt began trading its first two financial futures contracts; a contract based on the real time index of 30 blue-chip stocks and a contract on ten-year German Government bonds, with the same characteristics as the contract traded on LIFFE since late 1988. A new Japanese exchange, the Tokyo International Financial Futures Exchange (TIFFE), opened on June 30, 1989 and offered trading in three contracts: a Euro-yen interest rate future, a Eurodollar interest rate future, and a yen/dollar currency future. Most of TIFFE's activities, however, are concentrated on the Euroyen interest rate contract, used mainly by banks and securities houses to hedge movements in short-term domestic interest rates. Stock index futures and options began trading in 1988-89 on the Tokyo and Osaka Stock Exchanges. The Singapore International Monetary Exchange (SIMEX) also started trading in a Euro-yen futures contract, as well as options on the Euro-yen contract. Other instruments introduced during 1989-90 include a Japanese Government bond futures contract offered by the Chicago Board of Trade (CBOT) and a U.S. Treasury bond futures contract offered on the Tokyo Stock Exchange.

While overall trading activity on organized exchanges for derivative products rose sharply during 1989-90, there were significant differences in trading volumes for some of the most important futures and options contracts. Futures and options on the German Government bond and on the deutsche mark expanded sharply during 1989-90, reflecting uncertainty over the effects of German unification. Futures on U.S. Government bonds also remained strong with a sharp expansion of activity on the CBOT. Trading in futures on yen government bonds on the Tokyo Stock Exchange fell during 1989 and 1990. Trading in gilt-edged contracts on LIFFE declined during 1988-89, reflecting the authorities' buy-back program for long-dated gilts, but activity recovered in 1990 .

The recent growth of derivatives exchanges around the world has resulted in a sharp decrease in the market shares of the Chicago Mercantile Exchange (CME) and the CBOT, whose joint activities fell from about 75 percent of world futures volume in the early 1980 s to 50 percent in the last five years. As a response to increased competition, as well as to resulting pressures for longer trading hours, these exchanges directed their efforts toward the development of electronic trading systems in order to provide a global 24-hour trading network. Similar pressures have also led to some consolidation of organized exchanges. The MATIF, for example, bought a 28 percent stake in an electronic futures operation set up by the Stockholm Options Market, and a merger between LIFFE and the London Traded Options Market is envisaged. In the view of some market participants, tougher competition, greater demands for capital, and the process of globalization have reduced the profitability of several lines of business; as a result, a stronger move toward consolidation and specialization is expected.

Interest rate and currency swaps have been the most actively traded over-the-counter derivative products. Initiated in the early $1980 \mathrm{~s}$, trading in these products reached an estimated $\$ 2$ trillion of notional principal amount outstanding by the end of 1989 , a 54 percent increase over the previous year (Table A24). Swap transactions during 1989 remained concentrated in a few currencies. In particular, the U.S. dollar accounted for 66 percent of interest rate swaps and 79 percent of currency swaps at the end of the year while the yen accounted for 9 percent and 45 percent, respectively. ${ }^{24}$ The rapid expansion of swaps reflects the flexibility they offer in the design of risk-management programs as well as the arbitrage opportunities arising from market imperfections and limitations on the portfolio choices available to investors.

\footnotetext{
24 Since each currency swap involves two currencies, the percentages of swaps denominated in all currencies total 200 percent.
} 


\section{Recent Developments in the Regulation and Supervision of Financial Markets}

T he trends in financial flows and asset prices discussed in the preceding section occurred in the context of a continuing process of financial market internationalization and integration. This process intensified during the 1980 s and has contributed to more efficient market mechanisms for the mobilization and allocation of savings, both nationally and internationally. Nevertheless, the resulting intensification of competition and pressure on profitability may, at the same time, undermine the viability of certain established institutions and market structures. Similarly, the increasing ease with which the location of financial activities may be shifted from one segment or jurisdiction to another may have adverse systemic risk implications. While there have been some instances of localized strains on financial institutions and markets, regulatory and supervisory systems have generally succeeded in containing disruptions.

The focus of this section is on international coordination and cooperation efforts in the regulation and supervision of financial markets. A central element of such regulatory and supervisory responses-developed over the last few years at the international level-has been the formulation of policies to ensure that the capital underpinning the activities of financial institutions is adequate. The risk-weighted capital adequacy requirements of the Basle Committee on Banking Supervision, analogous EC directives in this area, and related steps to extend similar treatment to nonbank securities firms provide the principal examples of such responses. To date, international policy coordination in the capital adequacy area has focused primarily on the appropriateness of capital relative to credit risk. But with increasingly active markets in a wide range of financial instruments and the blurring of institutional distinctions between various financial activities-a tendency that is likely to intensify as regulatory barriers are further eroded-increased attention has been devoted to improving the coverage of capital adequacy for market risks, particularly, risks of loss from adverse movements in exchange rates, interest rates, and equity prices.

\footnotetext{
Note: This section was prepared by Mohamed A. El-Erian, John Clark, Alessandro Leipold.
}

While capital adequacy remains central to the strengthening of regulatory and supervisory practices, it is widely recognized that this approach needs to be complemented by safeguards against the excessive concentration of risk. This has been reflected, inter alia, in concern about the appropriateness of loan-loss provision practices and the degree of portfolio diversification of financial entities. Accordingly, regulators have taken steps over the past few years to strengthen provisioning requirements-particularly for developing country exposure-and, more generally, to derive guidelines for measuring and controlling credit concentration. Similarly, since the process of market integration and internationalization has also been accompanied by the emergence of financial conglomerates, regulators and supervisors are now reassessing the nature, magnitude, and effects of contagion and other risks entailed by such corporate structures. Finally, new international initiatives have also been undertaken recently to prevent financial institutions' involvement as intermediaries in the deposit taking and transfer of funds derived from illicit activities-money laundering. This section covers the above issues in turn.

\section{International Capital Adequacy Standards}

In July 1988, the authorities of the Group of Ten countries endorsed proposals by the Basle Committee on Banking Supervision for the "International Convergence of Capital Measurement and Capital Standards." This agreement-referred to here as the accord-provides a framework for measuring riskweighted capital adequacy and setting minimum prudential standards for credit risks. The framework is already reflected in the national practices of several industrial countries and in the EC Directives on Solvency Ratio and Own Funds for credit institutions, which were adopted in 1989. In addition, the accord is increasingly being used as a reference point for other industrial countries and for developing countries engaged in comprehensive financial reforms.

The basic elements of the accord include the establishment of an agreed approach to defining the 
constituents of capital, assigning credit risk weights to various types of exposure, and setting minimum standards for the ratio of capital-to-risk-weighted assets. ${ }^{25}$ Group of Ten countries have agreed to comply fully with this framework by January 1, 1993. To facilitate implementation, transitional arrangements covering the period 1991-92 were established. In essence, the accord established a two-tier definition of capital: tier-1 capital ("core capital," covering equity capital and disclosed reserves), and tier-2 capital ("supplementary capital," covering other instruments, such as revaluation and undisclosed reserves, general provisions, subordinated loans, and hybrid debt-capital instruments). Several limitations are imposed on the inclusion of instruments in tier-2 capital, such as a 45 percent limit on unrealized capital gains on securities holdings and a limitation on subordinated debt equivalent to 50 percent of tier- 1 capital. The accord also provided for a minimum risk-weighted capital/asset ratio of 8 percent to be achieved by the end of 1992. A transitional minimum ratio of 7.25 percent applied for the end of 1990 . Assets were to be risk weighted according to five classes, carrying weights ranging from 0 percent to 100 percent.

A recent review by the Basle Committee on the implementation of the accord indicated that as of September 1990, the capital agreement was already in force in most of the main financial centers (including Canada, France, Germany, Japan, Sweden, Switzerland, the United Kingdom, and the United States). ${ }^{26}$ Requisite legislative revisions in regulatory frameworks or binding guidelines from the supervisory authorities were already in place in those centers. ${ }^{27}$ Several of these countries (e.g., Canada, Switzerland, the United Kingdom, and the United States) require more stringent minimum standards for certain banks than specified in the accord. While some countries have moved directly to the final standards, others have taken advantage of the transitional arrangements. In general, despite developments in stock markets during 1990 adversely affecting tier-2 capital, international banks in the Group of Ten countries met or exceeded by the end of the year the transitional standard of 7.25 percent. Moreover, a majority of the large international banks reported already meeting the final 8 percent standard.

In implementing the accord during 1990, a num-

\footnotetext{
25 For a detailed description of the accord, refer to International Monetary Fund, International Capital Markets (1989).

${ }^{26}$ Basle Committee on Banking Supervision (1990b).

27 In other EC countries, the agreement was to be implemented in parallel with their adoption of related EC Directives. Nevertheless, their existing practices already complied with the requirements of the accord.
}

ber of technical questions arose on the interpretation of certain provisions. These were handled on a case-by-case basis by national authorities, except for instances where conflicting decisions could create significant competitive inequalities; such instances required broader agreement under the auspices of the Basle Committee. One outstanding issue concerns the treatment of general provisions or general loan-loss reserves. In February 1991, the Committee issued a consultative paper on proposals to give greater precision to the inclusion of general loan-loss reserves in the definition of capital. The Committee intends to put forth a final amendment on this issue in the second half of 1991. In its proposals, the Committee sought to make operational the general principle of separating or "cleaning" general provisions that do not reflect an identified deterioration in the valuation of particular assets and that are freely available to financial institutions, thereby qualifying for inclusion as tier-2 capital, from provisions that are set up against identified losses or an identified deterioration of particular assets, thereby not qualifying as capital. As in other areas, deliberations have had to take account of substantial differences in national accounting and regulatory environments. These include the use of different "baskets" of countries for the establishment of provisions as well as variations in the treatment of provisions for regulatory capital purposes; some countries (e.g., France) have included all provisions in regulatory capital while others (e.g., Japan) exclude such provisions.

During 1989, the EC adopted three key directives for implementation of the single banking market bearing on such matters: the Own Funds, Solvency Ratio, and Second Banking Coordination Directives (Table 8). ${ }^{28}$ The directives are now being transposed into national legislations and are to be fully in effect across the EC by January 1993. The first two directives define the requirements for capital adequacy that, with the notable exception of not allowing unrealized capital gains to count as tier-2 capital, are consistent with the Basle accord. The Own Funds Directive, adopted by the Council in April 1989, establishes standard EC definitions of capital for prudential purposes, applicable to all credit institutions. The Solvency Ratio Directive, adopted in December 1989, harmonizes the approach to solvency issues by establishing, inter alia, counterparty risk weights and rules for the treatment of collateral and guarantees. Finally, the Second Banking Coordination Directive, adopted by the Council in December 1989, harmonizes rules for

28 For a description of the directives refer to Section IV of International Monetary Fund, International Capital Markets (1990). 
Table 8. Status of Selected EC Financial Directives

\begin{tabular}{|lll|}
\hline Directive & \multicolumn{1}{c|}{ Scope } & \multicolumn{1}{c|}{ Status } \\
\hline Second Banking & $\begin{array}{l}\text { Harmonizes laws and rules for credit } \\
\text { institutions; allows for institutions licensed } \\
\text { within one EC country to operate } \\
\text { throughout the EC } \\
\text { Establishes standard EC definitions of } \\
\text { capital for prudential purposes } \\
\text { Establishes counterparty risk weights, } \\
\text { treatment of collateral and guarantee, and } \\
\text { other solvency aspects } \\
\text { Harmonizes laws and rules for investment } \\
\text { services; allows for institutions licensed in } \\
\text { one EC country to operate throughout the } \\
\text { EC } \\
\text { Solvency Ratio }\end{array}$ & Adopted by the Council, December 1989 \\
Investment Services & Adopted by the Council, April 1989 \\
investment firms & Ander consideration by the Council \\
Capital Adequacy for & Anvestment Firms & Under consideration by the Council \\
\hline Source: The Banker: & &
\end{tabular}

the operation of credit institutions, allowing, in particular, institutions licensed in one EC country to operate throughout the Community.

Risk-based capital adequacy requirements have also been supplemented by other national measures seeking to place constraints on the maximum degree to which banks may lever their capital bases. In the United States, for example, a new minimum leverage ratio has been in place since the end of 1990, applicable on a consolidated basis to bankholding companies with assets of $\$ 150$ million or more. ${ }^{29}$ Banks are required to maintain minimum tier-1 leverage ratios calculated in relation to total consolidated assets (nonrisk weighted). The ratio has been set at 3 percent for institutions with a top composite rating under the system for bank-holding companies; institutions with lower ratings, as well as those experiencing or anticipating significant growth, are expected to maintain capital leverage ratios above this level.

Although the Basle capital adequacy requirements were formulated only two years ago their impact on bank balance sheets and activities are increasingly evident. In effect, resultant market pressures have encouraged banks to achieve the intended prudential adjustments before the stated deadlines. Initially, and notwithstanding some opposition to a system of risk weights that was seen

\footnotetext{
${ }^{29}$ For bank-holding companies with consolidated assets below this amount, the guidelines are applied on a bank-only basis unless the parent bank-holding company is engaged in nonbank activities involving significant leverage on the parent company or the parent company has a significant amount of outstanding debt that is held by the general public.
}

imperfectly to reflect the attributes of underlying assets, this involved the replenishment of bank capital through retained earnings and the raising of equity on then-buoyant world stock markets. Thus, Japanese banks-long viewed as maintaining relatively low capital ratios-are estimated to have raised some $¥ 6$ trillion of equity and equity-related finance between 1987 and 1989. The major U.K. banks are estimated to have raised $£ 4$ billion in new equity in the same period, while German and Italian banks increased their capital by 25 percent and 12 percent, respectively. Meanwhile, French banks increased their capital by 19 percent, with nationalized banks resorting to the issuance of perpetual notes and cross-equity participations with other state-controlled companies. After substantial capital-raising activities in 1987-88, new issues by U.S. banks subsequently slowed down, with the 14 largest banks reported to have increased their equity by only 4 percent in 1989 . As a result of these activities, and despite continued growth in bank assets, consolidated capital/asset ratios (unadjusted for risk weighting) rose in most industrial countries during 1989 (Table A25), most markedly in Japan and Switzerland.

The substantial weakening of equity markets in 1990 , combined with deteriorating bank profitability due to erosion of low-cost sources of funding and the increase in nonperforming assets, subsequently constrained additional increases in core capital. Accordingly, it appeared that banks were increasingly seeking to limit asset growth, particularly as regards those assets carrying high risk weightings, and resorting to the issuance of subordinated debt instruments as needed. Against this 
background, stronger emphasis was placed on ensuring an appropriate return on assets, with greater selectivity in lending being accompanied by more careful, and more risk-sensitive, pricing. The effects of such strategies were quickly reflected, inter alia, in higher margins on corporate loans and in the rationalization by some banks of their developing country loan portfolios. At the same time, major cost-cutting programs were initiated by several internationally active banks.

Progress in implementing international capital adequacy requirements for banks has been accompanied by a growing recognition of the need for similar treatment for nonbank securities firms. Policy objectives in this area include adequate investor protection, the avoidance of regulatory arbitrage between banks and nonbanks, and the promotion of fair competitive conditions in terms of a "level playing field." The emphasis on capital ratios, as opposed to quantitative limitations, has reflected the need to strengthen the underlying financial position of firms, while minimizing nonprice distortions that may adversely affect the distribution of financial activities. To meet such objectives, regulators have placed increased stress on the need for a common framework, applied internationally, for measuring and designing appropriate capital adequacy standards for securities firms. Work in this area is being conducted under the auspices of the International Organization of Securities Commissions (IOSCO), which issued an initial report in June 1989 that proposed basic principles for such an international framework. These include risk-based requirements to take account of position and settlement risks, as well as base coverage for "nonmeasurable risks," such as general management risk. The topic was addressed at the November 1990 meeting of IOSCO, on the basis of a comparative study on capital requirements in France, Japan, the United Kingdom, and the United States. ${ }^{30}$ Delegates generally recognized the need for a more detailed common framework that would allow for the establishment of harmonized regulations, and further work in this area is to proceed in the context of collaboration between securities supervisors, the Basle Committee, and the EC.

Within the European Community, a draft EC directive on capital standards for investment firms is under consideration. The directive seeks to harmonize capital standards for investment firms through the specification of risk-based capital requirements, of categories of risks to be covered, and of accounting and reporting procedures. The draft includes minimum standards for start-up and

\footnotetext{
30 International Organization of Securities Commissions (1990).
}

ongoing capital, as well as requirements related to business type, position risk, and foreign exchange risk. It proposes that member countries with nonsegregated ("universal") banking systems select between applying the already approved bank directives to the aggregate activities of banks, or to separate the securities activities by "carving out" the trading book and making it subject to the securities standards.

The proposed capital adequacy standards for EC investment firms would be adopted alongside the draft Investment Services Directive, which would apply to noncredit institutions the "passport" principle of the Second Banking Coordination Directive. Firms with authorization in one EC home country would not be required to obtain a separate license for operations in other EC countries and would be subject only to a notification requirement. As in the case of the draft capital adequacy directive and the banking directives, supervision would be conducted by home country authorities with information provided to other national authorities on request. Progress in finalizing the directive has been slowed by differences on a number of issues, including the extent to which securities business should be required to pass through recognized national exchanges or be allowed to take place offmarket.

\section{Capital Adequacy Requirements for Market Risks Assumed by Banks}

Following the progress achieved in harmonizing capital requirements in terms of credit risk, increasing attention is now being devoted by bank supervisors to ways of improving the treatment of market risks when assessing overall capital adequacy. Three types of market risks, in particular, are being considered: foreign exchange risk (the risk of loss from adverse exchange rate movements), interest rate risk (the risk of loss from adverse interest rate movements), and position risk in traded equity securities (the risk of loss from movements in the market price of equities). Banks' exposure to such risks has increased in recent years, in line with the deregulation of interest rate and the lifting of capital controls, the broadening of the range of bank activities into the securities field, and increasingly active markets in a wide range of financial instruments.

The Basle Committee, in collaboration with IOSCO members, has been a major forum for international deliberations on this issue. As with the treatment of credit risk in the accord, the approach thus far emphasizes the use of minimum capital requirements as the appropriate regulatory instrument to achieve international convergence on the 
treatment of market risks. The Committee's work in this regard has highlighted numerous conceptual and technical difficulties in defining and measuring market risk and taking account of offsetting risk positions. This is particularly the case in the area of interest rate risk where important methodological questions have arisen, for example, regarding the treatment of indefinite maturity assets and liabilities, and the extent and stability of negative covariance between short and long maturities, and different instruments and currencies. In regard to position risk in equities-where the Committee is advocating a two-tier approach based on the quality of the issuer and the bank's net exposure to movements in the equity market as a whole-difficulty has emerged on the definition of equity, the offsetting of positions in different national markets, and the treatment of variations in the degree of liquidity associated with different securities. Work on setting capital requirements on banks' open foreign currency positions has focused on the measurement of single currency exposure, the measurement of risks inherent in a mix of long and short positions in different currencies, and the determination of appropriate capital ratios. As with capital requirements on credit risks, the formulation and implementation of capital requirements on market risks may be expected to induce financial institutions to adjust their on- and off-balance sheet positions. The nature and extent of such adjustments would depend, inter alia, on the importance of interest and exchange rate operations, with U.K. and U.S. institutions accounting for an important portion of such operations, and on the extent to which the use of hedging techniques is considered in setting capital requirements.

At the national level, the introduction of new regulations in the various areas of market risk has been generally limited to date, reflecting, in part, anticipation of international initiatives on the issue. The German authorities, however, recently introduced specific capital requirements for off-balance sheet items. With effect from October 1, 1990, the Federal Banking Supervisory Office amended its principles concerning bank capital to take supervisory account of the dynamic trend in the off-balance sheet transactions of German banks that underlie forward contract positions in the broadest sense. The volume of such transactions grew from 29 percent of on-balance sheet operations at the end of 1986 to 56 percent at the end of 1989 , with a relatively large dispersion around these average estimates. The new regulations limit, in quantitative terms, the risks arising from off-balance sheet transactions through expanding the general counterparty risk principle beyond credit risk and laying down capital-related ceilings for open positions. Thus, banks are required to include, in their capital cover- age, risks arising from financial swaps, forward contracts and options rights. In accounting for these risks, banks may use either the original-exposure method (which involves multiplying the nominal amount of the transactions by a maturity-related percentage weight) or the marking-to-market method (involving aggregating the current replacement cost and an add-on). Total price risks are to be limited to 60 percent of banks' liable capital, with disaggregated limits for individual risk categories.

\section{Issues in Monitoring Large Credit Exposures}

During the recent past, increasing attention has been devoted to the harmonization of monitoring and control practices governing large credit exposure and encouraging the spreading of risks through portfolio diversification. This attention is likely to increase in the context of the more acute financial difficulties facing selected groups of borrowers. The October 1990 International Conference of Banking Supervisors discussed the issue on the basis of a report prepared by the Basle Committee. ${ }^{31}$ The report advocates a limit on bank exposures to nonbank private borrowers of $10-40$ percent of capital on a fully consolidated basis, with 25 percent as the preferred central point, and stresses the need to pay careful attention to loans to "connected borrowers." It was agreed that this report should form the basis of a "best practices guide," which was issued by the Basle Committee in January 1991. The guide concludes that a sound supervisory system requires a range of supervisory elements to prevent excessive concentration, with an overall limit on individual private sector nonbank exposures of not more than 25 percent of total capital.

The application of credit exposure limits necessitates a clear specification of both the credit coverage and the counterparty. In defining credit exposure, the Basle Committee favors a comprehensive definition that includes not only standard bank loans but also all on- and off-balance sheet positions subject to the counterparty default risk (e.g., securities participation and off-balance sheet contingencies). The counterparty is also defined in a broad manner in order to ensure that related borrowers are treated as constituting a single exposure. The latter reflects the recognition that institutional and operational linkages (e.g., through common ownership, management, or cross-guarantees) may imply a large contagion risk within bank portfolios. When applied in isolation of other portfolio monitoring instruments, quantitative credit exposure limits run

\footnotetext{
3 Basle Committee on Banking Supervision (1990a).
} 
the risk of ignoring sizable single exposures that, while important in the aggregate, are individually not large enough to exceed exposure limits. Such "clustered" loan portfolios are more vulnerable to potential credit risk than more diversified ones, as are portfolios with heavy concentration in certain geographic regions, economic sectors, or industries. Citing difficulties of definition and other constraints, the Basle Committee report stresses the need for close monitoring of these issues by supervisory authorities rather than the application of quantitative rules.

\section{Supervision of Financial Conglomerates}

Market integration has been accompanied in recent years by a tendency toward greater institutional concentration in financial systems. The main contributing factors have been the need to maintain or expand market shares and take advantage of perceived economies of scale. Resulting tendencies toward concentration have taken a number of forms, including (a) mergers among banks in the same country (e.g., ABN-AMRO and NMBPostbank in the Netherlands; Provinsbanken, Danske Bank, and the Copenhagen Handelsbank in Denmark; PK Banken and Nord Banken in Sweden; Mitsui and Taiyo Kobe banks in Japan); (b) crossborder bank mergers and acquisitions (e.g., Deutsche Bank (Germany) and financial institutions in Italy, Portugal, and Spain; Crédit Lyonnais (France) and institutions in Belgium and Germany; and Barclays and National Westminster banks (U.K.) and institutions in France, Italy, and Spain); and (c) mergers and "strategic alliances" between bank and nonbank financial institutions (e.g., banks moving to acquire securities companies in France, Canada, and the United Kingdom). Some banks have also increased their participation in nonfinancial enterprises, most notably in France. This tendency toward the creation of financial conglomerates is expected to persist as a result, in part, of the erosion of regulatory-induced separations between different financial services. Such erosion is most evident in Canada, Japan, and the United States, which had long maintained a formal segmentation between banking and securities markets.

Draft legislation was submitted in late September in Canada, which proposed allowing various types of financial institutions to engage directly or indirectly in one another's business, with the main exception of retail insurance. The proposed measures complement a process of structural reform, initiated in 1987, which began modifying traditional regulatory barriers between four broad categories of financial institutions (the "four pillars")- banks, securities companies, trust companies, and insurance companies. The first step was to allow federally regulated banks, trust companies, and insurance companies to take an ownership interest of up to 100 percent in securities firms. The newly proposed steps would, if approved, allow for (i) banks to own trust companies; (ii) banks and trust companies to own insurance companies; (iii) insurance companies to own trust companies; and (iv) any widely held financial institutions to own "schedule-2" banks. ${ }^{32}$ "Significant" changes in ownership would be subject, inter alia, to the approval of the ministry of finance. In addition to providing additional opportunities for diversification, the proposals allow for expanded business functions within established institutional structures. For example, insurance companies would have enhanced abilities to make consumer and commercial loans, while trust companies would be granted the same in-house opportunities as banks. The proposed changes would also be accompanied by new prudential measures to discourage self-dealing. The federal Superintendent of Financial Institutions would be provided with new powers to receive additional information on the operation of financial institutions. At the same time, industry selfregulatory mechanisms would be strengthened, and institutions would be required to put in place internal procedures to manage conflicts of interest within the expanded structures.

In the United States, increasing attention is being devoted to reforming laws and regulations separating commercial and investment banking and limiting interstate banking, in the context of efforts to improve the competitiveness and stability of financial institutions and markets. Proposals to this end are included in the U.S. Treasury Department's study for modernizing the U.S. financial system released in early February 1991 and summarized in the following section of this report. That study reflects growing pressure for reform of the U.S. financial system, both in the wake of problems in the deposit insurance system and in view of the efficiency costs imposed by existing structures. The legal segregation between different providers of financial services has also come to be seen as inhibiting appropriate risk diversification on both sides of intermediaries' balance sheets. The relative loss of market shares and competitive standing of U.S. banks, for example, as well as the relatively

32 Banks in Canada are classified into two groups: schedule-1, which are broadly held (i.e., subject to an individual shareholding limit of 10 percent), and schedule-2, which can have dominant shareholders. Historically, the domestic banks have been schedule-1 banks and the foreign banks schedule- 2 . That distinction is now less firm, for example, one domestic bank (Laurentian Bank of Canada) is now a schedule- 2 bank. 
high incidence of financial disruptions in the United States, is indeed often partly attributed to the geographical and functional segmentation of financial services. The case for relaxing, in particular, legislative restrictions on interstate banking and on bank involvement in securities activities has been strengthened by their gradual effective erosion through the actions of state governments and the liberal interpretation of federal regulations. For example, the Federal Reserve has been increasingly permissive in its interpretation of the legal requirement that banks may not "principally engage" in securities activities (Section 20 of the GlassSteagall Act). In 1989 and 1990, this relaxation was reflected in regulatory decisions to (i) increase (from 5 percent to 10 percent of total revenue) the allowable contribution of securities activities to a bank's total earnings; ${ }^{33}$ (ii) authorize two U.S. bank-holding companies to act as agents in the private placements of bonds; (iii) approve, subject to "firewall" conditions, the applications of five U.S. and three foreign bank-holding companies to underwrite all types of debt and equity securities; and, (iv) allow, also subject to restrictions, four banks to underwrite and deal in U.S. corporate stocks. In early 1991, the Federal Reserve Board granted three additional banks, two of which are foreign, approval to underwrite and deal in U.S. corporate equities.

Analogous work is proceeding in Japan on the reform of regulations separating banking and securities activities (Article 65 of the Securities and Exchange Law). The Japanese financial system is characterized by a large degree of specialization and segmentation. The separation of banking and securities markets, for example, is supplemented by a split within the banking market between longterm, short-term, and trust activities. In July 1990, the Financial System Research Council (affiliated with the Banking Bureau of the Ministry of Finance) issued a second interim report on the reform of the Japanese financial system, following up on an earlier study published in May 1989. ${ }^{34}$ While the earlier study had identified five possible structures for the organization of banking and securities activities, the new report focuses on two of these alternatives. Under the first of these, both banks and securities houses would be able to set up separate subsidiaries to carry out either banking or securities activities. Alternatively, a multifunctional unit approach would allow a range of banking and securities activities under one roof at the whole-

\footnotetext{
${ }^{33}$ In 1987, the Federal Reserve Board had determined that securities activities by an affiliate of bank-holding companies do not violate Section 20 provided earnings from those activities are less than 5 percent of the affiliate's total revenues.

34 Financial System Research Council (1990).
}

sale level. Another study was published a month earlier by the Fundamental Research Committee of the Securities and Exchange Council (affiliated with the Securities Bureau of the Ministry of Finance). ${ }^{35}$ The report emphasized that if banks were to be allowed into the securities business, then it would need to be through separate subsidiaries, and effective firewalls would have to be put in place to limit problems related to conflict of interest and contagion.

The trend toward the emergence of financial conglomerates raises major regulatory and supervisory challenges. These include (i) identifying the risks inherent in financial conglomerates; (ii) assessing the magnitude of contagion effects and the effectiveness of firewalls (i.e., the extent to which problems in one area of a conglomerate will erode prudential capital underpinning other areas or affect agent confidence in other areas); (iii) avoiding conflicts of interest and insider trading, while limiting the dispersion of management control; (iv) establishing efficient monitoring mechanisms that accommodate the need for remedial action in chronic loss-making areas of conglomerates that are effectively subsidized by profit centers elsewhere; and (v) avoiding the de facto extension of public safety nets. Potential difficulties in these areas are compounded by substantial variation in the nature and evolution of the structure of financial conglomerates, both within and across national borders, and by the fact that holdings may include both supervised and unsupervised entities. This, in turn, has led regulators to seek a broad menu of policy responses.

An important element in the specification of appropriate policy responses is consolidated supervision of conglomerates to the fullest extent possible. At the national level, increased cooperation between bank supervisors and regulators of other types of financial institutions has recently been more prevalent. The form of such cooperation has tended to vary, encompassing (i) formally consolidating supervisory powers (e.g., in Nordic countries where the supervision of insurance activities has been integrated with that of banks under the auspices of the central bank); (ii) establishing formal though not fully integrated coordination mechanisms between regulators (e.g., the "collegiate system" in the United Kingdom where interested supervisors meet as a committee chaired by the agency responsible for the most important element of the conglomerate); and (iii) increasing contacts between the main supervisors, with formal deliberations sometimes supplementing informal consultations (e.g., in the United States).

35 Fundamental Research Committee of the Securities and Exchange Council (1990). 
At the international level, the Basle Committee on Banking Supervision has established formal mechanisms for consultations with securities regulators and is in the process of doing so with insurance regulators. Discussions with securities regulators have covered the need for, and implications of, partial relaxation of constraints on the freedom of regulators to pass on prudential information to other regulators at home and abroad. Key issues in these discussions involve important differences in regulatory approaches to various financial activities, approaches that reflect historical, institutional, and industry-specific "cultural" differences. The basic characteristics of supervised activities tend to differ across sectors. In the case of securities firms, for example, most assets are marketable and therefore subject to observable price fluctuations, which result in similar fluctuations in a firm's net worth. Since firms have to meet losses as they occur, regulators typically place considerable emphasis on liquidity. This may be contrasted with the experience in the banking sector, where-in the case of relatively narrow banks-regulators typically focus less on short-term changes in asset values and more on the underlying solvency positions through capital requirements.

The supervisory challenges posed by the growth of financial conglomerates was one of the main issues discussed at the October 1990 International Conference of Banking Supervisors. In its review of supervisory issues, the conference noted the clear trend in many financial centers toward enterprises comprising mixed financial functions across banking, securities, and insurance sectors. In view of the complexity and diversity of the associated risks, it endorsed the need for a "combination of approaches" that is flexible enough for national supervisors to apply to unique corporate structures. To render such approaches effective, the conference stressed the need for cooperation between the regulators and supervisors of the component parts of individual groups.

\section{Recent Initiatives Against Money Laundering}

In an increasing number of countries, money laundering, which may be described as the attempt to convert or dispose of resources derived from illegal activities in such a way as to conceal their illicit origin, has been criminalized. While most efforts to prevent the criminal use of the financial system for such purposes have been undertaken nationally, increasing attention has recently been focused on furthering international cooperation and developing common standards in this area. The trend reflects the international dimension of certain criminal activity, in particular narcotics trafficking, as well as the possibility that efforts to combat money laundering internally may be frustrated by the channeling of transactions through overseas channels. In such cases, the ability of national authorities to trace the final placement of illicit proceeds risks being frustrated by divergent national reporting standards or by restrictions on the cross-border sharing of information. Moreover, while the general trend toward liberalization of capital controls internationally may be expected to have positive effects on the efficiency of domestic and international capital markets, concern has arisen that the removal of internal and cross-border controls may have the undesirable effect of facilitating the clandestine channeling and placement of illicit proceeds.

International efforts to combat money laundering have generally involved (a) establishing common minimal standards for customer identification; (b) establishing criteria for detecting and reporting suspicious transactions; (c) improving means for international cooperation by facilitating greater information sharing by competent national authorities; and (d) establishing means for cross-border collaboration on the freezing and confiscation of assets related to criminal activity. Various international organizations, including the Council of Europe, INTERPOL, the Mutual Assistance Group between customs administrations, and the Customs Cooperation Council have devoted considerable attention to these goals. The issue of money-laundering has also been addressed in several international forums and through initiatives to convene specialized task forces.

The United Nation's "Vienna Convention against Illicit Traffic in Narcotic Drugs and Psychotropic Substances" (the "Vienna Convention"), adopted on December 20,1988, deals with drug trafficking in general but contains specific provisions related to the laundering of drug money. It creates an obligation for signatories to criminalize money laundering related to drug trafficking, contains provisions to facilitate international investigations, and extends extradition practices to money-laundering cases. It also sets out the principle that banking secrecy should not interfere with international cooperation related to criminal investigations. The Convention became an official body of international law on November 11, 1990 when the required minimum of 20 countries acceded to or completed ratification of the treaty. By the end of 1990,32 countries, including five industrial countries ${ }^{36}$ had ratified the Convention.

The Statement of Principles of the Basle Commit-

\footnotetext{
36 Canada, France, Italy, Spain, and the United States.
} 
tee on Banking Supervision (the "Basle Statement of Principles"), agreed to on December 12, 1988, applies to banks and recommends that they should make reasonable efforts to identify their customers, refuse knowingly to assist money-laundering operations and cooperate with law enforcement officials to the extent permitted by local regulations relating to confidentiality. Although the statement is not a binding legal document, member countries of the Basle Committee have used various formulas to bind banks under their national jurisdiction to detailed and precise norms in these areas. The statement has also received support from supervisory authorities not represented on the Committee, including members of the Offshore Supervisors Group.

At the July 1989 economic summit meeting in Paris, the heads of state or government convened a Financial Action Task Force, consisting of representatives from summit participants and other interested countries. The mandate of the Task Force was to assess the results of cooperation already undertaken to prevent money laundering through the financial system and to consider additional preventive measures. The Report of the Task Force, issued in April 1990, noted that in order to prevent drug traffickers from exploiting discrepancies between national measures to fight money laundering, minimum standards should be adopted to build upon and enhance the Basle Statement of Principles. It recommended that the suggested measures be applied to nonbank financial institutions that would be permitted or required to play a more active role in bringing suspicious activities to the attention of law enforcement officials. It also recommended that countries consider the establishment of universal reporting of all cash transactions above a fixed amount. Furthermore, the report called on countries to improve their capacity to respond expeditiously to requests from authorities of other countries for information relating to suspicious transactions, persons, or corporations. The findings of the Task Force were endorsed at the Houston economic sum- mit of industrial countries in July 1990, and the Task Force was reconvened for the purpose of assessing and implementing the various recommendations. All OECD and financial center countries subscribing to the Task Force's recommendations were invited to participate.

These international coordination efforts have been accompanied by several regional initiatives. In December 1990, the finance ministers of EC member countries agreed to recommend to their respective governments that legislation making money laundering a criminal offense be introduced into their respective national legal codes. In April 1990, representatives of the 32 members of the Organization of American States met in Ixtapa, Mexico to discuss the drug issue and related problems, including money laundering. Over half of the participants ( 18 countries) joined in the signing of the "Declaration of Program of Action of Ixtapa," which recommended the criminalization of money laundering, the enactment of laws to facilitate tracking and seizure of assets related to drug trafficking, and efforts to improve cooperation among signatories in combating money laundering. They also convened an inter-American group of experts to draft model legislation in these areas. Finally, in May and June 1990 , representatives of more than twenty Caribbean nations and territories as well as north, central, and south American countries met in Aruba to form the Caribbean Financial Action Task Force. ${ }^{37}$ The participants agreed to recommend to their governments that laws criminalizing money laundering and permitting the confiscation of assets related to drug trafficking be introduced and that regulations governing bank licensing, record keeping, and reporting of currency transactions be strengthened.

37 Antigua, The Bahamas, Barbados, Bermuda, British Virgin Islands, Colombia, Costa Rica, Dominica, Grenada, Guatemala, Honduras, Mexico, Jamaica, Montserrat, Netheriands Antilles, Panama, St. Lucia, St. Vincent and the Grenadines, Trinidad and Tobago, Venezuela, and the United States and the U.S. Virgin Islands. 


\section{Key Issues in Official Safety Nets and International Financial Markets}

T hroughout the $1970 \mathrm{~s}$ and $1980 \mathrm{~s}$, major domestic and offshore financial markets played an increasingly important role in the financing of large current account and fiscal imbalances in the industrial countries, the allocation of global savings across countries and regions, and the provision of borrowed international reserves. The stability of international capital flows, exchange rate arrangements, and the reserve system has thus become more dependent on the stability of international financial markets and their attendant payments, clearance, and settlement systems. ${ }^{38}$ In consequence, an extended disruption of these systems could clearly have highly adverse systemic effects on global trade and capital flows.

The stability of national financial systems has traditionally been underpinned by official safety nets designed to prevent financial disturbances from spilling over onto the real economy. While the nature of these safety nets has differed across major industrial countries, they have generally encompassed the provision of short-term emergency liquidity assistance by central banks, some form of private or official deposit insurance (to reduce the incentives of depositors to rapidly withdraw funds during a crisis), and direct short- or medium-term emergency assistance for large troubled financial institutions. While such policies can help contain the effects of a financial crisis, they expose the authorities to credit risks either through lending at the central bank's discount window, lending to troubled financial institutions by the government, or deposit insurance obligations. To limit the authorities' exposure to such credit risk, official safety nets have also incorporated policies specifying minimum capital adequacy standards for financial institutions, systems of prudential supervision, and limits on risk taking by institutions and individuals.

\footnotetext{
Note: This section was prepared by Donald J. Mathieson, Steven Fries, and David Folkerts-Landau.

38 Payments, clearance, and settlements systems encompass the transfer of both money and securities. In some cases, this involves the transfer of money as the counterpart to the purchase of goods; whereas, in other cases, there may be an exchange of money for securities. In either case, these systems complete the transfer of money and securities and record the change in ownership.
}

The increased integration of financial markets, both within and across countries, has raised new questions about the design and cost-effectiveness of national safety nets. As financial liberalizations in the major industrial countries have removed restrictions on domestic and cross-border financial transactions, there has been a sharp expansion in international capital flows, the domestic activities of foreign financial entities, the degree of competition in domestic financial markets, and the pace of financial innovation. As a result, concern has been heightened about the credit risks to which governments are exposed through official safety nets. Specific issues are (1) whether existing systems of prudential supervision can adequately monitor the activities of domestic institutions in foreign markets and foreign firms in domestic markets; (2) whether foreign institutions should be allowed (or required) to participate in national deposit insurance arrangements; (3) whether deposits in the foreign branches and subsidiaries of domestic financial institutions should be protected by the domestic deposit insurance system; (4) which central banks, if any, would be willing to provide emergency liquidity assistance in offshore markets; (5) whether official deposit insurance and other guarantees might stimulate greater risk taking by some financial institutions or individuals; and (6) what steps, in general, might be needed to ensure the cost-effectiveness of official safety nets.

This section examines some of these issues by first considering the rationale for official safety nets and then reviewing the key components of the safety nets in the major industrial countries. The effects of these safety nets on financial stability and risk taking in the private sector are next discussed, and finally, there is an examination of recent reform proposals that have been made in the United States to improve the cost-effectiveness of its official safety net.

\section{Rationale for Official Safety Nets}

During the twentieth century, most major industrial countries experienced periods of significant financial instability, particularly in the 1930 s and in periods surrounding major wars, that involved widespread failures of financial institutions, sharp 
declines in asset prices, and disruptions of both national payments, clearance, and settlement systems and the intermediation of credit. The perception that such financial instability contributed to sharp declines in real activity and employment led the authorities in the major industrial countries to establish policies and institutions that created an official safety net designed to promote financial stability and to limit the spillover effects of financial crises onto the real economy.

Much of the consequent debate on the need for official safety nets has focused on the contagion or systemic risk that the failure of illiquid or legally insolvent financial institutions can create. An example of contagion is a banking panic in which there is a sudden increase in the perceived riskiness of holding deposits, and depositors demand a large-scale conversion of deposits into currency. In the absence of an official safety net, adverse information about the value of an institution's portfolio, such as news of the bankruptcy of a principal borrower, could lead forward-looking depositors to participate in a run to avoid trying to withdraw their funds after the institution's liquid assets have been exhausted. Similarly, widespread banking panics could occur if many borrowers fail in a severe depression or if the failure of one institution raises concerns among depositors about the viability of other institutions because depositors are imperfectly informed about the viability of individual banks. ${ }^{39}$

Avoiding the real costs of a banking (or liquidity) crisis has been an important consideration in formulating public policies. Although the exact magnitude of these costs is subject to dispute, the perception of policymakers is that they can be substantial. This reflects the view that it is costly, if not impossible, for participants in the interbank market and other wholesale and retail depositors to distinguish between an illiquid but solvent bank and an economically insolvent institution. As a result, banks, in general, and the interbank market, in particular, are unlikely to be able to organize a means of allocating liquidity in the event of a crisis. ${ }^{40}$

An alternative view is that banking crises are rare events and that an economically solvent bank generally experiences little difficulty in obtaining sufficient liquidity by borrowing from other banks or possibly selling assets to meet its maturing liabilities. ${ }^{41}$ Moreover, in the event of economic insol-

\footnotetext{
39 For theories of banking panics, see Gorton (1985), Jacklin and Bhattacharya (1988), and Chari and Jagannathan (1988).

40 Representative of this viewpoint are Bhattacharya and Gale (1987) and Goodhart (1987). Evidence on contagion in the interbank market is mixed. For example, see Saunders (1987) and Davis (1989).

${ }^{41}$ Representative of this viewpoint are Schwartz (1988), Kaufman (1988), and Goodfriend and King (1988).
}

vency, a bank run ensures the timely closure of a troubled institution. This perspective emphasizes the role of the interbank market for high-powered money and its ability to perform well in periods of increased uncertainty about the riskiness of banks. Provided that there is not a widespread increase in the demand for currency by the nonbank private sector, the interbank market in principle can allocate high-powered money to meet the liquidity needs of individual banks, using collateralized loans if necessary. A central bank serving as lender of last resort would then be required to provide liquidity only in the unlikely event of a failure of the interbank market or a widespread portfolio shift from bank deposits to currency.

While banking panics provide highly visible, historical examples of systemic risk, much of the current concern about contagion focuses on national and international payments, clearance, and settlements systems. Explicit and implicit deposit insurance guarantees in many countries have significantly reduced the incentive for retail depositors to participate in a bank run. As the scale of global securities and foreign exchange trading has grown rapidly in the past two decades, the credit risks inherent in the operations of these payments, settlements, and clearance systems have increased accordingly, creating concern that there is now a greater potential for liquidity crises and contagion. In most payments systems, for example, the potential for contagion exists because any party with access to the system may not have sufficient funds to meet its payments obligations at time of settlement, ${ }^{42}$ and such a counterparty failure could create payments difficulties for a broad range of other participants.

In addition to reducing the costs associated with liquidity crises and disruptions to payments, clearance, and settlement systems, a broader rationale for an official safety net is the view that the authorities may have to act to preserve confidence in the financial system, sustain the credit intermediation process, and prevent extreme losses of wealth in the private sector. ${ }^{43}$ This view envisions an official safety net that extends well beyond provision of temporary liquidity to money markets and could

\footnotetext{
42 Some systems accumulate payment instructions over a period of time and only net debits and credits are entered into the settlement accounts of the members at the end of the settlement period. In such a payments system, there is the credit risk that a member would not have sufficient funds to meet its net debit at the time of settlement. In other systems, such as Fedwire in the United States, the central bank guarantees that payments instructions will be fulfilled (payment finality) even if a financial institution fails. A detailed analysis of systemic risk in payments systems is undertaken in Folkerts-Landau (1990b).

${ }_{43}$ Representative of this viewpoint are Kindleberger (1978), Solow (1982), and Bernanke and Gertler (1990).
} 
potentially encompass government assistance for important nonbank as well as banking institutions and possibly support of asset prices (including equity prices) ${ }^{44}$ in the event of a financial crisis.

Proponents of this view have argued that assistance for important nonbank financial institutions (such as large securities houses) may at times be needed to prevent a major disruption of the financial intermediation process, in general, and the extension of credit to businesses, in particular. While the failure of a single nonbank financial institution might affect only a narrow set of borrowers, it has been suggested that widespread failures of such institutions would disrupt normal creditor-borrower relationships and, in the face of the general uncertainties created by a crisis period, borrowers would find it difficult to find new sources of funds. Such a credit "squeeze" would force nonfinancial firms to sharply curtail their output and employment.

The view that, on some rare occasions, the authorities may need to intervene in asset markets generally reflects concern that large, abrupt declines in asset prices can (1) have a highly deflationary effect on consumer spending (through wealth effects) and investment activity (because of increased uncertainty $)^{45}$ and (2) create widespread bankruptcies of financial institutions (including banks) that are holding these assets. Although it has been recognized that the authorities cannot stand against the tide if economic fundamentals imply that asset prices must fall, some analysts have argued that there are times when asset markets become "disorderly" and bid-ask spreads widen drastically in response to imperfect information. In these situations, timely official assistance may help to maintain orderly markets and prevent unwarranted asset price volatility. In this regard, it is often noted that governments and central banks in the major industrial countries regularly intervene in government securities and foreign exchange markets by acting as a willing buyer or seller of last resort when these markets are viewed as disorderly.

It is not clear what influence these narrow and broad views on the role of official safety nets have

44 For example, Heller (1989) has proposed that the U.S. Federal Reserve could intervene in the stock index futures market to help stabilize equity prices in a crisis period.

45 If investment decisions are not reversible, the uncertainty created by a financial crisis may depress business fixed investment and household spending on durables. For example, a firm that makes an investment decision must trade off the extra return from early investment against the benefits of increased information gained by waiting. In a financial crisis, the firm would be less sure about the return it will earn on an investment, and the benefits gained by waiting for more information would increase and investment would decline. For theories of irreversible investment decisions under uncertainty, see Cukierman (1980) and Bernanke (1983), and, for empirical evidence of their significance, Romer (1990). had on the design and evolution of official safety nets in the major industrial countries. To an important degree, this reflects the fact that the authorities have often been purposely vague about the conditions under which some types of official assistance will be available. This vagueness arises because of concerns that the certainty of official assistance could induce a pattern of risk taking in the private sector that would ultimately require official assistance to financial institutions or markets that could be expensive for taxpayers. Indeed, a fundamental dilemma is that, while official assistance during a financial crisis can limit the effects of the crisis on real activity and income, the knowledge or expectation that such assistance will be available may alter the behavior of managers, creditors, depositors, and owners of financial institutions in such a way as to make a crisis more likely, which could create large future credit risks for the authorities. While the dilemma exists in all financial systems, the diversity of the institutional, supervisory, and legal arrangements that comprise official safety nets in the major industrial countries suggests that the authorities in these countries have followed somewhat different paths to confronting this dilemma.

\section{Key Components of Official Safety Nets in Major Financial Systems}

Official safety nets in the major industrial countries have encompassed (1) the provision of emergency liquidity assistance and official guarantees to the financial system to promote financial stability and (2) systems of prudential supervision, regulation, and capital adequacy requirements to limit the authorities' exposure to credit risks.

\section{Sources of Official Assistance and Guarantees}

Managing liquidity crises has involved the central bank's traditional function of providing emergency liquidity assistance to the money markets and the provision of assistance to specific institutions whose failure could have widespread systemic consequences. Since a liquidity crisis can produce sharp increases in holdings of currency and interest rates, central banks have traditionally stood ready to inject short-term liquidity into the market through open market purchases of securities or through the acceptance of securities at the discount window from individual institutions affected by depositor withdrawals. ${ }^{46}$ In general, access to the

46 When providing emergency liquidity assistance, central banks typically limit their credit risks by acquiring the most liquid and highest quality assets of the banking system. This 
discount window has been limited to licensed deposit-taking institutions.

In addition to providing emergency assistance during a general liquidity crisis, the authorities have at times provided special assistance to large institutions even when there was not a widespread crisis. Such assistance can take many forms, including enlarged access to the central bank's discount window, forming a support group of banks to extend special loans, helping to arrange the merger of the weak institution with a stronger institution, providing an infusion of capital into weak institutions, and government takeover of the institution.

There has been considerable debate over what types of institutions, if any, should be included in this "too-large-to-fail" category and what effects this policy has on private sector behavior. While large banks have typically received some form of private and official assistance during times of difficulty, ${ }^{47}$ the provision of such assistance for small and medium-sized banks and even large securities houses (e.g., Drexel Burnham Lambert) has been less certain. ${ }^{48} \mathrm{~A}$ key problem lies in identifying the circumstances under which an institutional failure would create a systemic problem. This is likely to depend on the role of the institution in national and international payments systems, whether it acts as a significant component of the clearance and settlement systems in a particular market (e.g., as a settlement bank in a futures or options market), and whether its failure would seriously undermine public confidence in the stability of comparable institutions. The authorities in all major industrial countries have been purposely vague about when (if ever) assistance would be made available to large institutions because of concerns that such assistance could weaken the incentives for depositors, creditors, and the owners of large financial institutions to monitor the activities of the managers of these institutions. ${ }^{49}$

reflects the fact that open market operations usually involve the purchase of government securities; whereas the assets that banks discount at the central bank must usually meet high standards for both liquidity and quality.

${ }^{47}$ For example, both private and official assistance were given to Continental Illinois in the United States in 1984

48 In Japan, Yamaichi Securities was assisted in 1965, and in Canada, several modest-sized commercial banks in the western provinces received substantial assistance during the $1980 \mathrm{~s}$.

49 The rationale for this vagueness was recently stated by Corrigan (1990, p.14) as:

With any troubled institution, but especially in the case of large institutions, I believe that the workings of both the safety net and market discipline will be better served in a context in which the authorities maintain a policy of what I like to call "constructive ambiguity" as to what they will do, how they will do it, and when they will do it. . . The circumstances associated with a particular case, the setting in which it occurs, and the assessment
Moreover, assistance to large institutions has seldom provided full protection for all creditors, depositors, managers, and owners. Although practices have differed across the major industrial countries, institutions that have required official assistance have typically had their senior management replaced, and owners or subordinated debtor bond holders have been assessed all or some significant proportion of the losses incurred by the institutions. Small depositors have usually been fully protected, while the position of large depositors and other creditors has been less clear. Although most deposit insurance systems limit the size of the deposit that is protected, large depositors have often been protected when large banks (e.g., Continental Illinois, Bank of New England) have experienced difficulty. In contrast, creditors have at times been protected and at other times have absorbed losses, especially if the creditors are holders of subordinated loans or bonds (which are counted as part of the institution's capital in most industrial countries). When the precedent has been established that creditors will be forced to absorb losses, then institutions that have weak capital and income positions have found it expensive to raise capital through subordinated debt. In the United States, for example, the cost of servicing subordinated notes issued by some money center banks, whose credit rating had been reduced, has recently risen to about $400-500$ basis points over the interest rate on comparable maturity U.S. Treasury securities.

While the central bank's discount window has often been viewed as an effective means of meeting a short-run liquidity crisis, all major industrial countries now have some form of deposit insurance to provide depositors with at least partial protection against bank insolvency. ${ }^{50}$ Although deposit insurance was introduced in the United States in 1933, most European countries and Japan did not have explicit deposit insurance programs until after the mid-1960s. For example, the Federal Association of German Commercial Banks established the Deposit Protection Fund for private commercial banks in 1966, and the French Bankers Association created a private insurance scheme in 1980 . These

of the relative costs and benefits of alternative courses of action will always have to be looked at case by case. But in no case should it be prudent for market participants to take for granted what actions the authorities will take and certainly in no case should owners and managers of troubled institutions-large or small-conclude that they will be protected from loss or failure.

so In systems with securities houses and brokerage firms, as well as banks, various investor protection arrangements have been created to help ensure that the securities and funds of investors are protected if a securities house or brokerage firm should fail. 
contrasting experiences reflected a number of historical factors. The United States had introduced deposit insurance following a series of banking panics that had resulted in widespread bank failures and a general loss of confidence in the banking system. Since the U.S. financial system included a large number of small and medium-sized banks, it was felt that general confidence could be restored to the system as a whole only if depositors were protected regardless of the size of the bank in which they placed their funds.

The absence of explicit deposit insurance in Europe and Japan during the $1950 \mathrm{~s}$ and $1960 \mathrm{~s}$ did not mean that depositors, especially small depositors, perceived that they were exposed to large risks. In that period, regulatory restrictions on the activities, location, instruments and, in some countries, interest rates of financial institutions limited both competition and portfolio choices of financial institutions. Restrictions on competition enabled protected institutions to strengthen their income and capital positions; whereas restrictions on activities and instruments were viewed as a means of limiting risk taking. ${ }^{51}$ Tight prudential supervision, especially of large financial institutions, featured prominently in Japanese and European systems. Moreover, banks that got into difficulty were typically assisted directly or indirectly (e.g., through merger) so that at least small depositors did not suffer any losses. ${ }^{52}$ The move toward explicit deposit insurance (whether private or official) in Europe and Japan appears to have reflected in part the desire of depositors for more certain protection and of the authorities for a means of financing heretofore implicit deposit guarantees in a world in which restrictions on the domestic and foreign activities of financial institutions have been relaxed and in which there have been periods of asset price volatility and global financial shocks.

The structures of the deposit insurance systems in the major industrial countries nonetheless differ widely in terms of the amount of insurance provided, the institutions allowed or obligated to participate in the systems, the relative roles of private and official sources of insurance, and the extent to which insurance funds have been utilized. ${ }^{53}$ The most important similarity between the deposit insurance systems is that they all have a formal limit stipulating that only deposits up to a certain

si The capital controls used by Japan and many European countries in this period also limited external risk-taking activities.

52 For example, when Bankhaus Herstatt failed in 1974, the German banking association set up an emergency fund to reimburse small depositors, but some larger depositors reportedly lost up to 55 percent of their funds.

$53 \mathrm{~A}$ comparison of deposit insurance arrangements can be found in U.S. Congressional Budget Office (1990). size are insured. ${ }^{54}$ Moreover, while nonbank, nonresidents' deposits in domestic banks are covered (up to the formal limit) by the deposit insurance systems in all major industrial countries, interbank deposits are not formally covered by the bank insurance funds in France, Germany, Japan, and the United Kingdom. In addition, although all five of the largest industrial countries allow or require the deposit-taking domestic branches of foreign banks to participate in their insurance systems, some have not formally extended coverage to deposits in foreign branches of domestic banks. Finally, while some countries (such as the United States) rely solely on official insurance systems, other countries (such as Germany and France) rely on banking association arrangements.

While the presence of a lender of last resort and deposit insurance have played a key role in preventing banking panics, their existence has forced the authorities to assume some credit risk and created concerns about a potential "moral hazard" problem. As with other types of insurance, an official safety net must confront the problem that the insured may behave differently just because of the existence of insurance. If fully insured, depositors would have little reason to worry about or to monitor the riskiness of their bank's activities. ${ }^{55}$ In this situation, depositors would not demand that a risk premium be incorporated into the yield they receive on their deposits as the riskiness of a bank's portfolio increases, and an element of market discipline on banks would thus be weakened. As a result, the cost of using deposits as a source of funding for lending activities would be reduced relative to the cost of using equity. ${ }^{56}$ Even in the absence of greater risk taking by financial institutions, increased reliance on deposits would reduce the "buffer" between the cost of an institution's failure and the obligations of the taxpayer. Moreover, managers of some financial institutions, especially

54 Despite these legal limits on deposit insurance, the authorities in all major countries have at times taken steps to protect all depositors from loss. As a result, the number of instances in which either small or large depositors have incurred actual losses has been rare.

55 Even when there are limits on the extent of deposit insurance, the authorities face a "time inconsistency" dilemma (a policy that works best in the short run may not be best in the long run and vice-versa) with regard to uninsured large deposits. Once a bank is on the verge of failing, it often appears that the best policy is to protect all depositors, both insured and uninsured, so as to prevent a disruption of the financial markets, especially if the bank is large. Uninsured depositors will then learn over time that, whatever the announced policy, their deposits are protected. In this situation, uninsured depositors will also have a reduced incentive to monitor the activities of banks, and an element of market discipline will be lost.

56 The incentive to substitute deposits for equity as a source of funding would be increased if deposit insurance is provided at a low cost to financial institutions. 
those close to insolvency, might have an incentive to undertake an unduly high share of potentially high return but also high-risk activities under the assumption that, with good outcomes, they will reestablish the financial position of the institution, but, with bad outcomes, the losses will be absorbed by the deposit insurance fund or ultimately by the taxpayer. The effects of this moral hazard problem on risk taking and institutional structures are discussed later in this section.

\section{Measures to Limit Official Credit Risks}

Concern about the potential costs of the credit risks associated with official safety nets has led to the implementation of policies designed to limit those risks. The measures have involved the establishment of minimum capital adequacy standards, financial codes, restrictions on risk taking, systems of prudential supervision, and systems for managing the risks inherent in payments, clearance, and settlement systems.

Capital adequacy requirements have been seen as a means of both strengthening the ability of financial institutions to withstand the effects of financial and real sector shocks and helping to overcome the moral hazard problems created by the existence of an official safety net. There is clear historical evidence that, in the absence of official safety nets, financial institutions have held high ratios of capital to assets. For example, in the United States, commercial banks had an average capital/asset ratio that exceeded 20 percent throughout the period from 1844 to $1900 . .^{57}$ Between 1914 (when the Federal Reserve was established) and 1934 (when the Federal Deposit Insurance Corporation (FDIC) was formed), the average capital/asset ratio of banks declined to about 15 percent. By the mid-1980s, this average ratio stood at 6 to 7 percent before beginning to rise again (Table A17). To strengthen the capital positions of banks, the Group of Ten countries in July 1988 reached agreement on new capital adequacy standards for international banks, which will come fully into effect at the end of 1992 . The new standards specify the minimum amount of bank capital in relation to the credit risks that banks incur in their on- and most off-balance sheet activities (see Section III). ${ }^{58}$ Such capital adequacy

\footnotetext{
57 Until the 1870 s, the average ratio of capital to assets exceeded 30 percent.

58 Capital adequacy standards for securities houses are also being discussed by the International Organization of Securities Commissions (IOSCO). While progress has been made, there has been a problem in defining equivalent capital standards across systems where banks' participation in security activities and transactions differs markedly (e.g., in Japan and the United States versus Germany).
}

standards could play a role in improving the costeffectiveness of an official safety net both by creating an additional buffer between the costs of institutional default and the taxpayer and by introducing an additional element of market discipline by forcing banks to raise capital in the equity markets.

To make the official safety net cost-effective and to ensure that financial markets are perceived to operate fairly, major financial systems incorporate codes of behavior, limits on risk taking by individuals and financial institutions, and prudential supervision arrangements. Financial and commercial codes define broadly the range of activities in which intermediaries may legally engage. An important element in these codes is the establishment of appropriate accounting standards and disclosure requirements. Limits on risk taking have also played a role in efforts to limit the credit risks associated with an official safety net. While the experience of the 1930s led many major industrial countries to establish a variety of restrictions on risk taking in order to create more stable financial systems, the financial liberalizations of the $1970 \mathrm{~s}$ and 1980 s encompassed a weakening or removal of many of these restrictions..$^{59}$ As discussed in previous International Capital Markets reports, the limitations on risk taking included restrictions on external financial transactions, a separation of commercial and investment banking, segregation of insurance and banking activities, limitations on commercial ownership of banks, prohibitions on the use of certain types of financial instruments (e.g., options), exclusion of individuals and institutions from certain markets, and restrictions on portfolio holdings of various individuals and institutions. ${ }^{60}$ When combined with appropriate macroeconomic policies and strong prudential supervision, these limitations on activities and portfolio choices were initially perceived as a means of promoting a stable financial system by creating financial institutions with strong market and capital positions, limiting speculative behavior and risk taking, and restricting competition.

By the early 1970 s, it was increasingly evident that those restrictions that limited competition were

\footnotetext{
${ }^{50}$ Even prior to these liberalizations, some of these restrictions were evaded through the emergence of new financial products and institutions and operations in offshore financial markets.

60 The restrictions on portfolio holdings encompassed limits on bank lending to individual borrowers, on the concentration of loans to a single industry or type of borrower, and on the types of business that could receive loans (e.g., banks in some countries may not make residential mortgage loans). Other financial institutions, such as insurance companies and pension funds, were required to invest in assets of a certain minimum credit rating and were often limited in terms of the foreign assets they could hold.
} 
having an adverse effect on the efficient provision of financial services and were distorting the allocation of credit. In addition, exchange restrictions and limitations on holdings of foreign assets were actually increasing the risks confronting domestic residents by preventing them from holding internationally diversified portfolios. As a result, many restrictions on activities, instruments, and portfolio holdings were removed, and increased emphasis was placed on ensuring that market participants have adequate information upon which to base their financial decisions. This process has involved the removal of exchange controls, the relaxation of restrictions on the entry of foreign financial firms into domestic markets, the removal of interest rate ceilings, the introduction of new types of financial instruments (e.g., financial futures and options), and the relaxation of restrictions on competition between different segments of the domestic financial system. ${ }^{61}$ Some restrictions on risk taking, particularly by individuals, remain in all countries, however, to ensure adequate consumer protection.

Prudential supervision to enforce financial codes and capital adequacy requirements has traditionally been viewed as a necessary complement to lenderof-last-resort assistance in order to make the official safety net cost-effective. Since one of the principal objectives of prudential supervision is to ensure that difficulties confronting a financial institution are corrected before the institution fails, the ability of the regulatory authorities to identify the difficulties and to take prompt corrective action depends on the source of the difficulty, the extent of the deterioration in the institution's financial position, and the speed with which the problem arises. Some observers have expressed concern that the growing complexity of financial activities and instruments, the increased frequency of global financial shocks, and the expanding scale of foreign and offshore activities of domestic financial institutions have added new obstacles to implementing effective prudential supervision. For example, new financial activities and the use of new financial instruments may make it difficult for the supervisory authorities to gauge the nature of the future risks that are likely to confront the financial institution. Moreover, large macroeconomic shocks may suddenly and adversely affect the financial positions of a broad range of financial institutions. While diversification of a financial institution's operations across countries can help reduce the effects of shocks occurring in a single country, global or systemic shocks could make it difficult to either implement a gradual program of corrective action or prevent institutional failures.

61 This liberalization process is analyzed in Mathieson and Folkerts-Landau (1988).
As the scale of activities of the foreign branches and subsidiaries of domestic financial institutions expanded with the removal of exchange controls and relaxation of restrictions on the entry of foreign firms into major markets, supervisory authorities were also confronted with the task of deciding who had responsibility for supervision of institutions in different markets. ${ }^{62}$ The dilemma was partly addressed through a multilateral agreement (the Basle Concordat in 1975) between supervisors in the major industrial countries that established supervision of capital adequacy on the basis of consolidated balance sheets for banks and their foreign branches and majority-owned subsidiaries. Other subsidiaries would be supervised by the authorities of the country in which they were located. Collaborative efforts on such matters continue.

An important reason why the financial crises of the 1970 s and 1980 s in the major industrial countries had only limited short-run effects on real activity is that they did not extensively disrupt major national and international payments, clearance, and settlement systems. Financial liberalization and the growing integration of major markets have led to a sharp increase in the volume of transactions both within and across these systems; consequently, concern has been raised about the ability of existing institutional arrangements to cope with the new volume of transactions and to manage effectively the risks created by counterparty failure and liquidity crises.

At the core of current international monetary arrangements lies an interlocking network of national and international payments systems, which facilitate the exchange of funds associated with almost all international trade and financial transactions. While some domestic payments systems are operated by the central bank (such as Fedwire in the United States), other clearing house systems are operated by private corporations or syndicates. The largest private payments system is the Clearing House Interbank Payments System (CHIPS), which is owned by the New York Clearing House Association and handles U.S. dollar payments associated with foreign exchange transactions involving the U.S. dollar and Eurodollar transfers. In some systems, official and private payments systems are parallel. In Japan, for example, there is both the Zengin system and the Bank of Japan Net system; the Bank of Japan is the settlement bank in both systems. ${ }^{63}$

${ }^{62}$ For a more detailed discussion of these issues, see Folkerts-Landau (1990a).

63 A large private offshore payments system is the Chase Manhattan U.S. dollar payments system, which operates in Tokyo when U.S. domestic payments systems are closed. 
In a number of countries, the central bank's role in the payments system is regarded as an important element in the safety net, especially when the central bank provides for payments finality. Such payments finality allows banks and their customers to make transfers of funds during the day without necessarily having first to immediately provide funds to cover the transfer and to receive funds with the assurance that such transfers will not subsequently be revoked by the failure of the sending party. In operating a payments system that provides such assurances, the central bank typically extends daylight overdrafts to some participants and thereby assumes some credit risk. As the volume of financial transactions expanded with the growing integration of financial markets, the scale of these daylight overdrafts began to grow; authorities in a number of countries have taken steps to limit the credit risk they face.

An example of these risk-reduction efforts is the steps taken by the U.S. Federal Reserve. The Federal Reserve introduced a payments system riskreduction scheme in 1986 that focused on controlling the direct Federal Reserve credit risk associated with the extension of intraday credit on Fedwire, which had reached a daily average of $\$ 65$ billion, by establishing a maximum amount of intraday overdraft that depository institutions were permitted to incur. ${ }^{64}$ In July 1987 , the Federal Reserve adopted a two-step 25 percent reduction in these caps. The Board of Governors Large Dollar Payment System Advisory Group then recommended that a fee be imposed on daylight overdrafts ${ }^{65}$ so as to induce the creation of a private sector market to replace much of the Federal Reserve funding of intraday credit. It was anticipated that such a fee would help reduce the use of daylight overdrafts by delaying less critical payments, shift payments from Fedwire to CHIPS, stimulate greater use of netting arrangements, and further the development of an intraday federal funds market.

While clearing and settlement systems for securities and derivative (options and futures) instruments are generally operated by private clearing houses, these entities may extend significant amounts of credit, especially on an intraday basis. Indeed, the possibility of default by major participants in the settlement systems for stocks and stock index options and futures was regarded as the greatest

64 The caps were defined as a multiple of the depository institution's capital. These caps were subsequently extended to CHIPS. A more detailed discussion of this risk-management policy can be found in Folkerts-Landau (1990b).

65 The fee was to equal 25 basis points on the daily average overdrafts, less a deductible equal to 10 percent of capital, and it was to be phased in over a three-year period beginning in 1991. threat to the financial system during the October 1987 global equity market crash. ${ }^{66}$ Concern about the stability of these systems led the Group of Thirty, a private group concerned with the working of the international financial system, to propose steps for establishing central securities depositories by 1992 , introducing netting systems if they would reduce risk and promote efficiency, and the adoption of a universal settlement date on $\mathrm{T}+3$ (i.e., three days after the trade date).

Market participants and the Group of Ten central banks have also been studying the feasibility of multilateral netting arrangements for managing better the risks in foreign exchange markets. ${ }^{67}$ Dealers in foreign exchange typically enter into successive contracts to buy or sell various currencies, often with the same counterparty and the same date of delivery. ${ }^{68}$ Given the time differences between the hours of operation of major foreign exchange markets, and the chance that one counterparty might fail before settlement occurs, there can be extended periods involving settlement risk. ${ }^{69}$ In consequence, it has been proposed that multilateral netting be achieved through the creation of a central counterparty or clearing house, whose legal structure would be similar to that of clearing houses for futures and options, and which would help reduce these settlement risks. ${ }^{70}$

\section{Economic Effects of Official Safety Nets}

Although the scope and coverage of official safety nets in the major industrial countries can only be vaguely and imprecisely defined, the perception,

66 The failure of Drexel Burnham Lambert disrupted the settlements system for mortgage-backed securities in the United States.

67 The Bank for International Settlements published in November 1990 a "Report on Netting Schemes," prepared by the Committee on Interbank Netting Schemes composed of senior officials from the Group of Ten central banks, that examined how netting arrangements could help reduce the scale of transactions and risks in clearance and payments systems for foreign exchange and securities.

68 A survey by the Bank for International Settlements indicated that the average daily foreign exchange trading volume in the major markets had reached $\$ 640$ billion in April 1989.

$69 \mathrm{It}$ is generally thought that these settlement risks are greatest for transactions involving trade of Japanese yen for U.S. dollars in Tokyo. A party that sells yen in exchange for dollars must irrevocably pay out the yen at least eight hours and most often fourteen hours before it receives payment in U.S. dollars.

70 This would leave each participant with net amounts due to or due from the clearing house equal to its multilateral net positions vis-à-vis other participants in the system. The clearing house would become the counterparty for each contract submitted by a pair of participants, and the clearing house would keep a running, legally binding net position for each participant for each currency and each date. 
often based on historical experience, that some form of official assistance would be available in a financial crisis has influenced the stability of global financial markets, the incentives for risk taking in the private sector, the allocation of credit both within and across countries, and the evolution of institutional structures.

While some thirty separate episodes of systemwide bank runs occurred in France, Germany, Japan, the United Kingdom, and the United States between 1790 and $1929,{ }^{71}$ there have not been any systemwide banking panics involving a general flight from bank deposits to cash or to foreign exchange in any major industrial country since World War II. Moreover, major domestic and international payments, clearance, and settlement systems have not experienced extended disruptions. Nonetheless, authorities in the major industrial countries have had to confront a number of financial crises during the $1970 \mathrm{~s}$ and 1980s that involved failures of both large and small financial institutions. ${ }^{72}$ While each crisis has been unique, one important characteristic of major financial crises in the 1980s was an increasingly rapid market response to institutional weakness, especially when there were doubts about whether certain types of institutions would receive assistance or whether certain types of deposits or liabilities would be protected.

This experience suggests that while official safety nets have reduced the risks involved in placing retail deposits in financial institutions, there are still significant elements of market discipline imposed on such institutions. Stock markets, credit rating agencies, and large depositors and creditors are sources of such discipline. A gradual deterioration of a financial institution's income and capital position typically results in a lower price for its equity, a reduced credit rating, a higher cost for credits and uninsured deposits, and a shortening of the maturities on the credits and deposits that it can obtain. If its financial position continues to worsen, a point can be reached at which large lenders and depositors simply stop extending funds to the institution. Moreover, a sudden, unexpected deterioration in a weak institution's financial position can trigger an abrupt withdrawal of credits and a run of uninsured depositors.

This type of market discipline, however, is a twoedged sword as far as the stability of the financial

\footnotetext{
7 Schwartz (1988) also argued that, between 1930 and 1933 . there were three system-wide banking panics in the United States and two in Germany. However, she characterized the events that led up to the suspension of convertibility of the domestic currency into gold in Japan and the United Kingdom in 1931 as exchange crises rather than banking panics.

72 The nature of these crises was discussed in International Monetary Fund (1991).
}

system is concerned. On the one hand, such discipline creates incentives for owners and managers of financial institutions to undertake prompt corrective action when their institution's financial position deteriorates; on the other hand, if managers ignore market signals or their financial position deteriorates suddenly owing to a macroeconomic shock, then a sudden withdrawal of funds could quickly lead to an institutional failure. An unmanaged failure could have systemic effects if it disrupts the payments system, contributes to the perception that other similar institutions are likely to face difficulty, or if the counterparty losses associated with its failure create difficulty for a broad range of other creditors, depositors, and (in the case of banks) correspondent banks.

In those cases where the authorities consider it necessary to assist a troubled institution (e.g., through arranged merger or receivership), the cost of such assistance is likely to be directly related to whether the authorities have the ability or the authority to close an institution or force it into receivership before it becomes economically insolvent (i.e., the market value of its net worth becomes zero or negative). The most costly episodes will occur when the authorities do not have the ability to act before the institution's net worth is reduced to zero. ${ }^{73}$

The progressive integration of major financial markets, the expanding activities of foreign financial institutions in major domestic markets, and the growing responsiveness of large depositors to institutional weakness have raised new issues regarding the provision of emergency liquidity assistance. The events of October 1987 and August 1990 demonstrated the speed with which large financial and macroeconomic shocks can spread across major domestic and offshore financial systems. This suggests that during a major crisis there could be a sharp simultaneous increase in the demand for liquidity across all major markets, or that the demand for short-term liquidity in a particular currency (e.g., the U.S. dollar) could emerge in offshore markets even when the domestic markets of the currency are normally closed for business. The growing importance of the branches and subsidiaries of

\footnotetext{
73 The costs to the U.S. authorities of rescuing Continental Illinois Bank were significantly lower (measured relative to the size of the bank's assets) than those for the savings and loan industry (again measured relative to this industry's total assets). In part, this reflected the fact that a run of large depositors forced the authorities to intervene in the Continental IIlinois case when the bank still had a modest positive net worth. In contrast, many savings and loans that ultimately failed were allowed to operate with increasingly negative net worth for an extended period. These institutions could continue to operate in this condition only because they could rely on government insured deposits as a source of funding.
} 
foreign banks (and other financial institutions) in major domestic markets also raises the issue of whether these institutions should have access to the domestic central bank's discount window during a liquidity crisis.

As mentioned, a fundamental problem with regard to risk taking is that an official safety net may make depositors and possibly creditors indifferent to the risks assumed by financial institutions, except in unusual circumstances. If depositors and creditors do not adequately monitor the activities of a financial institution and demand that appropriate risk premiums be incorporated in the interest rates they receive, then the incentives of the institution's managers and owners to control the risks they face could be blunted. In this situation, the main constraint on risk taking may be government capital requirements, regulation, and supervision rather than market discipline. Although elements of market discipline remain in all major financial systems, a key issue in some countries, such as the United States, is whether those elements and prudential supervision are sufficient to provide adequate constraints on risk taking, especially by managers of institutions that are nearly insolvent.

This moral hazard problem can affect both the distribution of credit within a given financial structure and the evolution of that financial structure over time. The underpricing of risk that can arise because of the safety net can artificially expand the resources allocated to finance risky projects. This may well crowd out investments with lower risk but also somewhat lower rates of return. When this occurs, the effect may be to shift the overall mix of investment in the economy toward high-risk and possibly high-return projects. Any shift toward greater funding of high-risk projects can require increases in the effort and resources used by supervisors and regulators to monitor and modify behavior. Institutions that are subject to such enhanced supervision also incur a variety of reporting and regulatory costs that reduce the implicit subsidy they receive from the safety net. These costs can in turn stimulate efforts by regulated institutions to shift some activities to either affiliated institutions or offshore markets. Associated changes in corporate structure or location may allow an institution to escape some regulatory or supervisory costs, while at the same time its domestic or foreign affiliate could be viewed by market participants as benefiting from implicit protection by the domestic official safety net. ${ }^{74}$ If these changes were to occur, there

\footnotetext{
74 For example, this could occur if a bank shifted some of its deposit-taking activities to a foreign branch. Since these deposits might not formally be part of the deposit insurance program of the home country, they would not be assessed deposit insurance premiums. Nonetheless, if the authorities had
}

could be an artificial stimulus provided to activities in offshore markets and the scale of gross capital flows.

An official safety net can also influence the evolution of an economy's financial structure. A key issue is whether the safety net effectively provides a net subsidy to some segment of the financial sector. Depending on its design, an official safety net can generate diverse benefits and costs for different financial institutions. For example, the availability of official deposit insurance (especially when it is underpriced), and the perception that short-term emergency liquidity assistance is likely to be available to an institution during a crisis period, can reduce its funding costs. Deposit insurance can reduce the risk premium that depositors demand be incorporated into the interest rate they receive on their deposits. Moreover, to the extent that creditors and owners perceive that the presence of an official safety net will enable an institution to better service its debts and equity claims over time, then the value of this assistance will also be reflected in the market prices of the institution's securities (both debt and equity). In addition, depository institutions may receive an indirect benefit if the central bank's operations in the payments system effectively reduce the costs of making payments and securities transfers. ${ }^{75}$

Partly offsetting these potential benefits are a variety of costs that are incurred by institutions that are protected by an official safety net. As already noted, depository institutions are typically faced with minimum reserve requirements on deposits, deposit insurance premiums, minimum capital requirements, and the costs of periodic reports to supervisory authorities. In addition, these institutions may face restrictions on the activities they can undertake (such as the separation of commercial and investment banking in Japan and the United States).

Although there is considerable debate about the scale and distribution of the net benefits or costs associated with the existence of an official safety net, there is no doubt that it can sharply alter the incentives for owning and operating different types of bank and nonbank financial institutions. For example, a net subsidy to a particular class of institutions can over time raise the proportion of total financial services provided by financial institutions that are protected by the safety net. Nonetheless,

previously taken steps during periods of institutional difficulty to protect offshore deposits, then there could be the perception that such actions would also be taken in the future.

75 For example, an institution's payments costs could potentially be reduced if the central bank extends daylight overdrafts (at a low or zero cost) so that payments can be made even when the institution does not have sufficient funds on deposit at the central bank. 
the value of the net subsidy received by different institutions or groups of institutions can evolve in unanticipated ways not necessarily connected with changes in the structure of the official safety net itself. Other regulatory changes and advances in telecommunications and computer technologies can affect the value of the subsidy and alter the competitive position of different types of financial institutions. ${ }^{76}$

\section{Proposals for Reform of the U.S. Official Safety Net}

The insolvency of a large number of thrift institutions and growing evidence of weakness in the income and balance sheet positions of commercial banks in the United States have raised concerns about the viability of the government's deposit insurance funds and the adequacy of supervision and regulation of depository institutions. (Key components of the U.S. official safety net are given in Box 1.) These concerns led the U.S. Congress to call for a comprehensive study of the deposit insurance system by the U.S. Treasury. ${ }^{77}$ The study, entitled "Modernizing the Financial System: Recommendations for Safer, More Competitive Banks" was issued in February 1991; its major recommendations are summarized in Box 2. This section examines the proposals that were put forth during public debate while the treasury study was being prepared; they concern reform of not only the deposit insurance system per se but also the overall structures of the official safety net and the financial system. To set the stage, the principal factors contributing to the current financial weakness in the U.S. financial system are examined briefly, and this is followed by a discussion of the reforms that were proposed to strengthen the financial system and improve the costeffectiveness of the official safety net.

A key factor stimulating discussions of reforming the U.S. financial system has been the emergence of widespread difficulties in the savings and loan industry. The origins of the savings and loan crisis can be traced to the late 1970 s and early 1980 s and

\footnotetext{
76 For example, Keeley (1990) argued that the deregulation of the financial system in the United States during the 1970s and $1980 \mathrm{~s}$, which removed some geographic restrictions on banks and allowed nonbank financial intermediaries to engage in activities previously restricted to banks, seriously eroded the market value (as reflected in the prices of bank equity) of a bank charter. Moreover, as the market value of bank charters declined, owners and managers of banks faced a smaller incentive to control the risks inherent in their loan portfolios because they had less to lose if they got into difficulty and their charter had to be surrendered.

77 This study was mandated by the Financial Institutions Reform, Recovery, and Enforcement Act of 1989.
}

illustrate the important role of capital adequacy requirements and prudential supervision in promoting a cost-effective safety net. Because of tax incentives and regulations, savings and loan institutions ended the 1970s holding long-term, fixed interest rate assets (primarily residential mortgages) funded by savings and time deposits with shorter maturities. This maturity mismatch exposed thrifts to considerable interest rate risk, which was realized when short-term interest rates rose relative to the fixed return on their assets as inflation accelerated in the late 1970s and was then followed by a sharp monetary tightening in the early $1980 \mathrm{~s}$. By the time that greater interest rate stability had returned, the thrift industry had incurred such extensive losses that it was left with virtually no capital. Authorities responded to these developments by relaxing the capital adequacy standards for savings and loans, and, at the same time, by expanding the lending activities that they were allowed to undertake, the deposit-taking powers, and the coverage of deposit insurance. These actions, in effect, permitted insolvent or significantly undercapitalized institutions to continue their independent operation presumably in the expectation that the savings and loans would use their new freedom to undertake activities that would allow them to earn profits and rebuild their capital positions.

Shortfalls in prudential supervision enabled many of these institutions to undertake relatively risky investments that were often funded by offering higher-than-average interest rates on government insured deposits. ${ }^{78}$ Lower energy and agricultural prices and regional downturns in real estate prices in the second half of the 1980 s led to a sharp increase in defaults in loan repayments by borrowers from many savings and loan institutions, which, in turn, caused a growing number of insolvencies of these institutions. In consequence, the savings and loan deposit insurance fund exhausted its resources, and a major injection of funds from the federal government was required.

While the most serious problems in the thrift industry were being addressed, a deepened concern arose about the financial strength of U.S. depository institutions, particularly commercial banks. Throughout the late $1970 \mathrm{~s}$ and $1980 \mathrm{~s}$, the U.S. banking industry faced increased competition from other domestic providers of financial services. For example, shares in money market mutual funds increased to $73 / 4$ percent of household holdings of credit market instruments at the end of 1989 from $1 / 2$ of 1 percent at the end of 1978. At the same time, commercial paper increased from 2 percent of non-

${ }_{78}$ The higher-than-average interest rates paid by these institutions indicate that a limited form of market discipline was being imposed. 


\section{Key Components of Safety Net}

\section{Lender of Last Resort}

The Federal Reserve has broad powers to provide liquidity to banks and, in exceptional circumstances, to extend liquidity support to other institutions. Under the Federal Reserve Act, any Federal Reserve bank may make advances to any member bank provided they are secured to the satisfaction of the Federal Reserve bank. The Federal Reserve may also discount eligible trade bills; for ease of operation almost all discount window borrowings are in the form of advances. The International Banking Act of 1978 enables the Federal Reserve also to make advances to any branch or subsidiary of a foreign bank that holds reserves with the Federal Reserve: the Monetary Control Act of 1980 extends reserve requirements to nonmember banks and provides for their access to the discount window on the same basis as member institutions. In addition, individuals, partnerships, and corporations other than depository institutions may be granted access to the discount window in unusual and exigent circumstances; no direct lending to such borrowers has been undertaken since the 1930s.

The Federal Reserve's Regulation A establishes the terms under which credit may be extended to eligible banks and other institutions. The terms that pertain to the lender-of-last-resort function of the Federal Reserve are primarily those of extended credit advanced for other than seasonal purposes. Other extended credit is available to any eligible depository institution that is experiencing liquidity strains owing largely to exceptional circumstances affecting that institution alone. If the credit is outstanding for more than sixty days, the rate on extended borrowing is raised above the basic discount rate according to a schedule. The rate that would be applicable to loans made to individuals, partnerships, and corporations in unusual and exigent circumstances would be established at the time of the loan.

The Federal Reserve may provide extended credit either to support an explicit program of management and financial reform, with a view to returning a troubled depository institution to a sound basis, or to make available bridge financing while arrangements are completed for merger with a stronger institution or for an orderly closing. In such cases, the Federal Reserve works in conjunction with the appropriate federal and state supervisory agencies and the Federal Deposit Insurance Corporation (FDIC).

\section{Deposit Insurance}

The FDIC provides explicit guarantees of deposits and assists in the resolution of failed institutions. I The FDIC, an independent government agency established in 1933, operates two separate deposit insurance funds, the Bank Insurance Fund for commercial

'Federal Deposit Insurance Corporation (1984, 1989). banks and some savings banks and the Savings Association Insurance Fund (SAIF) for thrift institutions. ${ }^{2}$ All member banks of the Federal Reserve System are statutorily required to carry federal deposit insurance, as are most nonmember state-chartered banks. Similarly, all federally chartered thrift institutions are required to join SAIF; participation is optional for some state-chartered institutions. The FDIC's explicit insurance coverage is limited to deposits up to a ceiling of $\$ 100,000$ a deposit, including interbank deposits and those in foreign currency. Under the International Banking Act of 1978, U.S. branches of foreign banks are eligible for FDIC membership; such branches must pledge to the FDIC a surety bond to secure the payment of domestic deposits. The FDIC charges a premium of 0.195 percent of insured, domestic deposits for its guarantee. ${ }^{3}$

The FDIC may provide assistance to depositors in a number of ways. First, it may be appointed as receiver of a failed bank or thrift institution by its chartering agency. In this case, it pays depositors their net balances up to the insurance limit and proceeds to liquidate the bank's assets. Uninsured depositors and other general creditors of the bank generally do not receive either immediate or full reimbursement of their claims. Second, it may undertake a so-called purchase-and-assumption transaction. Under this approach, a buyer purchases all or some of the failed bank's assets and assumes its deposit liabilities and certain of its liabilities. An important difference between a payoff and purchase-and-assumption transaction is that in the latter case all depositors, both insured and uninsured, receive full payment on their claims. General creditors also normally receive full payment on their claims. Third, it may transfer insured deposit and secured liabilities to another institution; uninsured and unsecured liabilities remain in receivership. Technically, the receiving bank is not purchasing the failed bank but rather acting as an agent for the FDIC by assuming the insured deposits. The FDIC pays the accepting institution an amount equal to the liabilities less any purchase price. Fourth, it may provide direct financial assistance to a bank that is in danger of failing. Generally, the FDIC's assistance covers the difference between the market value of the bank's assets and liabilities; new capital is injected by private investors. Finally, the FDIC may own and operate temporarily a bank until a permanent solution can be arranged.

2The Financial Reform, Recovery and Enforcement Act (FIRREA) of 1989 substantially altered the deposit insurance system. The bankrupt Federal Savings and Loans Insurance Corporation was dissolved and its liabilities were assumed by three other government agencies, including SAIF.

'Under FIRREA, the FDIC was given the authority to raise deposit insurance premiums to 0.12 percent from 0.6 percent on January 1, 1990, and to 0.15 percent on January 1, 1991. FIRREA also authorized the FDIC to increase these premiums under certain circumstances by a maximum of 0.075 percent in any given year, an authority it exercised in 1991. 


\section{U.S. Treasury Recommendations}

On February 5, 1991, the U.S. Treasury Department issued its report on the federal deposit insurance system, entitled "Modernizing the Financial System: Recommendations for Safer, More Competitive Banks," as required by the Financial Institutions Reform, Recovery, and Enforcement Act of 1989. In general, the recommendations aim to increase the market discipline faced by banks, to restructure banking regulation, and to eliminate many of the existing geographic and functional restrictions on banks.

Recommendations to increase the market discipline faced by banks include a phased reduction in the scope of deposit insurance coverage and the introduction of deposit insurance premiums related to the risks inherent in an institution's lending activities. Explicit coverage of deposit insurance would include only $\$ 100,000$ a depositor at each institution for ordinary accounts and $\$ 100,000$ a depositor at each institution for retirement accounts, eliminating the use of joint accounts and trust accounts to expand insurance coverage. ' Explicit insurance coverage would exclude certain fiduciary deposits, those of professionally managed pension funds, and brokered deposits. To curb the implicit scope of deposit insurance, the Federal Deposit Insurance Corporation (FDIC) would consistently use an existing legal provision that enables it to expose nondeposit creditors to normal pro-rata bankruptcy losses even if uninsured deposits are made whole by the FDIC's actions. Also, proposed legislation would require the FDIC to use the least costly resolution method to limit the coverage of uninsured deposits and other bank liabilities, although the U.S. Treasury and Federal Reserve could decide to protect uninsured deposits when "systemic risks" are judged to be present. Two recommendations are made regarding risk-based deposit insurance premiums. The first, for the short-term, would authorize the FDIC to establish risk-based premiums as a private insurer would, with capital levels used as the principal measure of bank riskiness. The second, for the longer-term, would establish a demonstration project to introduce a private insurance market into the process for pricing bank insurance premiums.

The main recommendation to restructure banking supervision is a system of capital-based regulation that rewards a well-capitalized bank with scope for expanded activities and expedited regulatory procedures and that subjects an undercapitalized bank to prompt and increasingly strong corrective actions. Measuring bank capital would be improved through annual on-site examinations for all banks, more accurate provisioning for loan losses, and increased market value reporting of assets and liabilities. Interest

'The current explicit coverage of individual deposit insurance is $\$ 100,000$ a deposit, with no firm limit on the number of such deposits per individual. Under this system, an individual may open numerous separately insured accounts within a single institution through separate insured "capacities" (e.g., joint accounts, trust accounts, individual retirement accounts, and so on). rate risk also would be included in risk-based capital standards. For undercapitalized banks, supervisory actions could include dividend restrictions, growth constraints, limits on risky activities of the bank and its affiliates, and management dismissals; such actions would intensify as a bank's capital declines. In addition, to minimize losses that could be incurred by the deposit insurance fund, regulators would be provided with new legal authority or other means to close a failing bank promptly, while it still has some low level of positive book capital.

With regard to regulatory agency restructuring, the report proposes to consolidate responsibilities for banking regulation in the treasury and the Federal Reserve. Within the treasury, the Office of the Comptroller of the Currency and the Office of Thrift Supervision would be consolidated into a new Federal Banking Agency (FBA) that would supervise all national banks, their bank-holding companies, and all thrift institutions. The Federal Reserve would supervise all state-chartered banks and their holding companies, while the FDIC would focus solely on the administration of the deposit insurance system and the resolution of failed banks and thrifts.

Also recommended is reform of the geographic and functional restrictions on banks to improve their competitiveness and attract capital to the banking industry. Specific recommendations include (1) immediate authorization for a national bank to branch into any state in which the bank's holding company is permitted to acquire a bank, and (2) authorization, subject to a three-year delay, for a bank-holding company based in one state to own a bank in any other state. The recommendations would thus permit full interstate branching after the three-year hiatus, effectively ending the branching restrictions of the McFadden Act of 1927. With regard to restrictions on functional activities, the proposed system of capital-based regulation would permit well-capitalized banks to affiliate with securities firms, mutual funds, and insurance companies within a new financial services holding company structure. The long-standing separation of banking from securities brokerage and underwriting activities under the GlassSteagall Act would cease; while a proposed authorization for commercial firms to be permitted to own financial services holding companies would erode the separation of banking and commerce.

To prevent an expansion of the federal safety net to nonbanking financial and commercial activities, a set of safeguard measures is proposed. They would include the authority for only a well-capitalized bank to affiliate with other types of financial firms; functional regulation of the bank and its affiliates; restrictions on a bank's lending to its affiliates and holding company; limits on a bank's dividend payments when capital is low; regulatory notification of large transfers between a bank and an affiliate; and authority for the regulator to limit bank lending to its securities affiliate or certain customers of the affiliate. 
financial corporations' total credit market liabilities to 5 percent. These competitive developments reflected in part recent advances in information processing and communications technologies that facilitated the operation of money market mutual funds and eliminated much of the traditional advantage banks possessed in assessing the credit risk of prime corporate borrowers.

As the banking industry faced increased domestic competition, its profitability weakened. While most banks continued to be profitable, the annual rate of return on equity of all insured commercial banks declined from an average of $12^{3 / 4}$ percent in $1975-81$ to an average of $9^{3 / 4}$ percent in 1982-89. Much of the decline in profitability was concentrated in money center banks. Their annual rate of return on equity fell from an average of $13 \frac{1}{4}$ percent in the earlier period to an average of $6^{3 / 4}$ percent in the later period.

U.S. financial institutions also faced increasing competition from foreign financial institutions both within the United States and in offshore and major domestic markets in other countries. Prospective developments in the EC and in Japan also suggested to many observers ${ }^{79}$ that some of the existing restrictions on the activities of U.S. financial institutions may make it difficult for those institutions to maintain or improve their competitive position in global financial markets. In particular, the movement of the EC toward community-wide banking and the Japanese discussions of reforming the Article 65 separation of commercial and investment banking were regarded as implying that institutions from these regions will soon have access to a larger deposit base and will be able to offer a broader range of financial services than U.S. institutions.

As noted in Section III, the provisions of the Glass-Steagall Act of 1933, which required the separation of most commercial and investment banking activities, and the McFadden Act of 1927, which limited bank branching across state lines, have been cited as playing a key role in limiting the services that can be offered by U.S. commercial banks and the development of a national deposit base. While U.S. banks have to a degree escaped some of these limitations through the operations of their subsidiaries in financial markets in offshore centers and other countries, they may still lose some of the economies of scale and scope associated with integrated domestic and international operations and a broader national deposit base. Moreover, restrictions in bank ownership may inhibit bank restructurings and thereby limit the

79 For example, see the testimony by the Honorable Nicholas F. Brady, Secretary of the U.S. Treasury, before the U.S. Senate, Committee on Banking, Housing, and Urban Affairs, July $25,1990$. extent to which the banking industry responds to changes in its competitive environment.

These considerations contributed to the view, advanced also in the U.S. Treasury study, that the reform of the U.S. financial system must extend beyond changes in the deposit insurance system and should encompass more comprehensive changes in capital adequacy standards, prudential supervision, and geographic and activity restrictions on financial firms. The structural issues that have been regarded as important include (1) the scope and pricing of deposit insurance guarantees; (2) the appropriate minimum capital adequacy standards; (3) how prudential supervision should be improved; (4) the appropriate relationship between banking and other financial services, and between banking and commerce; (5) the nature and extent of firewalls between parent and subsidiary institutions; and (6) greater use of market value accounting in evaluating the positions of financial institutions. In making recommendations for changes in the financial system, the authorities have indicated that they will be guided by the need to improve the competitiveness of U.S. financial institutions and markets as a means to strengthen their capitalization, to maintain the stability of the financial system, and to limit the exposure of the taxpayer through the official safety net.

Awareness of the potential costs that can be created by the moral hazard problem associated with the safety net in general and deposit insurance in particular has stimulated a discussion of how best to develop ". . . an institutional framework that, to the extent possible induces banks both to hold more capital and to be managed as if there were no safety net, while at the same time shielding unsophisticated depositors and minimizing disruptions to credit and payment flows." 80 The reform proposals advanced in various quarters, while the study was being prepared, included establishing 100 percent reserve (or narrow) banking, introducing risk-based deposit insurance premiums, implementing depositor or other private co-insurance, raising capital requirements, establishing prompt closure rules for troubled institutions, and imposing restrictions on banks' asset choices.

One proposal was to establish "narrow" banks that would invest only in high-quality, shortmaturity, liquid investments and recover their costs for providing checking accounts and wire transfers from user fees. Moral hazard would be regulated away because these banks would not be able to invest in risky assets, and instability would be over-

\footnotetext{
${ }^{80}$ Statement by A. Greenspan, Chairman of the Federal Reserve, before the U.S. Senate, Committee on Banking, Housing, and Urban Affairs, September 13, 1990, in Greenspan (1990), p.918.
} 
come because the deposits would be fully backed by safe and liquid assets. Establishing such narrow banks would obviously require a drastic change in the current U.S. financial structure and that of other industrial countries. Moreover, banking organizations would presumably locate their business and household credit operations in nonbank affiliates funded by uninsured deposits and securities issued on capital markets. Unless these organizations relied primarily on long-term funding, they would be subject to the same risks of creditor and depositor runs that any uninsured institution would normally face. If such a run were to occur, then the authorities would be confronted with the issue of either assisting these institutions (which again raises the moral hazard issue) or allowing the credit system to be severely disrupted.

Another proposal, which would not require a fundamental restructuring of major financial systems, would be the use of risk-based deposit insurance premiums ${ }^{81}$ The basic idea is to make the price of deposit insurance reflect the riskiness of the bank's portfolio, thereby reducing the subsidy for risk taking and achieving a more equitable distribution of the costs of deposit insurance across banks. To effectively administer such risk-based premiums, authorities must have some way of accurately assessing risk, which would require either the collection and analysis of extensive information about insured institutions or the reliance on market information to assess risk (e.g., through the use of reinsurance by the FDIC). Either approach has limitations in terms of cost and accuracy, and even if risks can be properly evaluated, the range of premiums necessary to induce significant behavioral changes in portfolio management might have to be many multiples of the existing premium. Nonetheless, while no major industrial country currently prices government deposit guarantees on a risk-adjusted basis, some broad-risk categories could be established and priced. ${ }^{82}$

Co-insurance makes the insured bear some of the cost of a bad outcome and has been widely used in the provision of private medical, fire, and automobile insurance. It has been argued that, if depositors were insured only up to, say, 90 percent of their deposits, they would have an incentive to monitor their banks' activities ${ }^{83} \mathrm{Co}$-insurance could also be

81 These risk-based insurance premiums could also be combined with the use of risk-based capital requirements that will be discussed subsequentiy.

82 This type of approach has been used in establishing the new Bank for International Settlements capital adequacy standards, as noted above.

${ }^{83} \mathrm{~A}$ related proposal has been to increase the use of subordinated debt as a source of bank capital. It has been argued that such nonrunable, but serially maturing, debt would provide for a periodic market evaluation of the bank and thereby introduce designed to protect small depositors by fully insuring deposits up to a certain size and then providing only partial protection for deposits in excess of that amount. Just as with current arrangements, such coinsurance would only have its desired effects if it was credibly established that large depositors would experience losses when a bank failed. And, if such credibility was attained, there would then be strong incentives for large depositors to run at the first sign of trouble. Indeed, even under current arrangements, where large depositors have generally not suffered losses, runs of uninsured deposits from banks under stress have occurred.

As already noted, another approach to reducing the moral hazard problem has involved the implementation of risk-based capital adequacy requirements, which reflect both portfolio and off-balance sheet risk. In addition, it has been proposed that these capital adequacy requirements could be strengthened by prompt corrective action whenever a bank's capital position is not consistent with minimum capital standards. This could initially involve forcing the bank to make credible commitments to raise additional capital, which, if not promptly met, would lead the authorities to require dividend reductions, restrictions on asset growth, limitations on the use of insured deposits, and sales of assets or affiliates with the resources used to rebuild capital. If these actions were not sufficient, then forced mergers, divestitures, and, if necessary, a conservatorship could be required while the bank still had some positive equity capital. ${ }^{84}$ In essence, the combination of enhanced capital adequacy requirements and prompt corrective action would be designed to simulate market pressures from risk taking without creating market disruptions. Nevertheless, even if these policies strengthened bank capital positions and the quality of their assets, they would not eliminate bank failures; their proponents have argued that some form of deposit insurance would still be necessary.

While there is wide support for strengthening the capital positions of financial institutions, concerns have been expressed that implementing these requirements when the income and capital positions of financial institutions are weak could adversely

additional market discipline. Such subordinated debt could also serve as an additional buffer for the deposit insurance fund over and above the owners' equity; however, the recent experience of some U.S. banks, whose credit ratings were downgraded, has shown that such subordinated debt can be quite expensive. In such situations, banks with weak financial positions may have only limited incentives to use such debt rather than relying on issuing additional equity or retained earnings. Nonetheless, institutions with strong income and capital positions may benefit from using subordinated debt to meet capital requirements.

84 Proponents have argued that this policy could be applied equally well to large and small banks. 
affect the availability of credit. This reflects the view that these institutions may have few options other than to reduce the level or growth of loans. ${ }^{85}$ Such reduced lending could adversely affect economic activity if otherwise creditworthy firms could not obtain funding for their current operations and investments. Proponents of enhanced capital adequacy have argued, however, that the activities that are likely to be curbed are exactly those high-risk activities that contribute the most to the moral hazard problem. Moreover, creditworthy enterprises have a variety of sources of funding for their activities; and financial institutions that are better capitalized are likely to be better able to adapt to technological change and macroeconomic shocks. ${ }^{86}$

Although all major industrial countries have acted to enhance capital adequacy standards and improve prudential supervision, concern has been expressed that these steps may not be adequate to overcome the moral hazard problem, particularly for banks undertaking a wide range of activities. As a result, some observers have suggested that new restrictions on the banks' or their affiliates ' activities may be needed. ${ }^{87}$ The concern appears to reflect the view that it is becoming increasingly difficult, in a world of rapidly changing telecommunication and computer technologies and financial innovation, for the supervisory authorities to adequately evaluate the risks inherent in banks' on- and off-balance sheet activities. This situation arises not only because of the difficulty involved in gathering timely information about the domestic and international activities of a bank and its affiliates but also because it is inherently difficult to evaluate the risks in new financial products. As a result, it has been argued that some new restrictions may have to be placed on the activities of deposit-taking institutions that are protected by the safety net or to force protected institutions to undertake certain activities in separately capitalized affiliates.

\footnotetext{
85 However, Furlong and Keeley (1989) have argued that a profit-maximizing bank would add additional capital, rather than sell assets, in the face of higher capital requirements if deposit insurance implicitly subsidizes the cost of deposits to the bank.

86 In establishing higher capital adequacy requirements, supervisory authorities have also been confronted with the possibility that, if requirements were raised in one country in isolation, financial institutions would shift activities to affiliated institutions in other domestic or offshore markets ("regulatory arbitrage"). Alternatively, if higher capital requirements were imposed on one type of institutional structure (e.g., banks), financial conglomerates would shift activity to a different corporate structure (e.g., a leasing company). To avoid creating such incentives, supervisory authorities have implemented higher capital adequacy standards in the context of a multilateral agreement and have taken steps to improve the capital adequacy of a broad range of bank and securities market institutions.

${ }^{87}$ The "narrow" bank proposal can be viewed as one such proposal, albeit an extreme version.
}

In most major financial systems, some restrictions on the activities of financial institutions still exist despite the extensive liberalization that has taken place over the past two decades. ${ }^{88}$ As already noted, for example, there is still a separation of commercial and investment banking in Japan and the United States, and, in a number of major industrial countries certain types of activity must be carried out in separately capitalized affiliates. An objective of these restrictions has been to try to ensure that the failure of institutions not protected by the safety net would not lead to problems of other (perhaps affiliated) institutions that are protected. Such restrictions have become increasingly difficult to enforce and may entail significant costs. Commercial banks from Japan and the United States regularly carry out investment banking activities in the Eurocurrency markets, and recent experience suggests that it may be difficult to maintain a firewall between a financial institution and its affiliates during a crisis. ${ }^{89}$ For example, when Drexel Burnham Lambert failed to meet its debt-servicing obligations in early 1990 , the separately capitalized government securities affiliate, which had not engaged in unusually risky activities, found that it lacked access to credit. ${ }^{90}$ Activity restrictions may also weaken the profitability of banks by restricting their access to profitable new markets for financial services and thereby contribute to an erosion of their capital. In addition, restrictions on bank's activities, location, and ownership may have weakened the industry's response to changes in its competitive environment. ${ }^{91}$ Indeed, recent calls for liberalizing the regulations governing bank ownership, and those contained in the Glass-Steagall and McFadden Acts, aim at restructuring the banking industry to strengthen its competitiveness.

${ }^{88} \mathrm{~A}$ more fundamental issue has been whether the U.S. banking structure should move from a system based on bankholding companies to one based on universal banks either of the style employed in the United Kingdom or in Germany.

${ }^{89}$ Even in normal periods, the protection of the safety net may be implicitly transferred to an affiliate. This can occur if a parent bank uses insured deposits to fund its loans to an affiliate or if the affiliate's borrowing costs are reduced because the market perceives that difficulties in the affiliate would lead the authorities to support the affiliate in order to protect the parent.

${ }_{90}$ Moreover, this affiliate also found it difficult to sell securities. This reflected the fact that, in the U.S. settlements system, the transfer of funds from the buyer to the seller of a security would take place within a shorter period than the transfer of title to the securities from the seller to the buyer. As a result, there was concern that the affiliate and the parent would enter into bankruptcy after the payment for the sale of a security by the affiliate had been received but before the title to the security had been transferred. The parent experienced similar difficulties in attempting to unwind its foreign exchange position and manage its positions in the commodities markets.

91 The effects of these restrictions are analyzed in Fries (1990). 


\section{Spontaneous Capital Market Financing for Developing Countries}

$\mathbf{T}$ his section discusses the process of re-entry to the international capital markets for developing countries and the factors affecting it. After providing an historical perspective on developing country access to those markets, it describes recent developments in spontaneous portfolio and bank flows. It then highlights some of the obstacles faced by developing countries as they attempt to return to normal borrowing arrangements and discusses techniques to address concerns (particularly regarding transfer and liquidity risks) among foreign porfolio investors. The section concludes by summarizing the factors that may facilitate market re-entry.

\section{Historical Background}

Prior to World War II, external financing of developing countries principally took the form of direct investment and sovereign bonds. Bank lending was limited mainly to trade and some project financing. A boom in bond underwriting took place in the $1920 \mathrm{~s}$, only to be followed by a virtual disappearance of the market for new issues after 1931, an extreme example of a recurrent pattern. ${ }^{92}$ After the war, official financing began to play an important role, largely reflecting bilateral development assistance following decolonization, while private financing tended to take the form of traditional bank credits and bond issues were rare. By 1970, more than 50 percent of the long-term external debt of developing countries was owed to official creditors, while bank debt and bonds accounted, respectively, for about 32 percent and 5 percent (Table 9). The relative importance of official debt was, of course, greater in the case of low-income developing countries, representing 84 percent of their total debt, with the share of commercial bank creditors below 5 percent. For the group of severely indebted middle-income developing countries, by contrast, the share of official creditors was about 28 percent, compared with 55 percent for commercial banks and 6 percent for sovereign bond holders.

\footnotetext{
Note: This section was prepared by Augusto de la Torre, Alessandro Leipold, and Can Demir.

92 For greater detail, see Eichengreen and Lindert (1989).
}

Private financing for developing countries increased dramatically in the $1970 \mathrm{~s}$ and early $1980 \mathrm{~s}$, as international bank credit markets gained a competitive advantage over securities markets in channeling the surpluses of oil exporting countries toward the developing world, particularly middleincome developing countries, mainly through the vehicle of general purpose, syndicated bank loans. ${ }^{93}$ Securities markets were open, however, and in the period 1977-81, for example, publicized new bond issues by developing country borrowers averaged around $\$ 3.5$ billion a year, or about 9 percent of total international bond issues. Algeria, Argentina, Brazil, Mexico, South Africa, and Venezuela largely accounted for this volume, although Chile, Colombia, the Philippines, and others were also in the market. While this type of financing was not insignificant for the individual developing countries that were frequent issuers, the overall flows through the bond markets paled in comparison with syndicated bank credit commitments, which rose from about $\$ 18$ billion in 1977 to a range of $\$ 30-50$ billion a year between 1978 and 1981 .

By 1982 , commercial banks held 50 percent of the long-term external debt of developing countries, while official creditors held 35 percent-with a marginal increase in the share of multilateral institutions being more than offset by a decline in the share of bilateral creditors. Debt to commercial banks represented of course a much larger fraction of the debt of the severely indebted middle-income

\footnotetext{
93 Two developments are considered central in explaining the comparative advantage of the international banking market in "recycling" the oil surpluses. First, there was a de facto widening of the official safety net in OECD countries in favor of money center banks, which reduced the risk of holding deposits in the international banking system. Central banks and deposit insurance agencies moved to assume a larger portion of default risk on money center deposit liabilities, while the official sector's informal encouragement for banks to play an active role in the recycling process was perceived to be backed by implicit understandings regarding the availability of lender-of-lastresort facilities. Second, legal innovations in syndicated loan contracts increased the risk of default to developing country borrowers by aggregating risks of various borrowers within the same developing countries (through cross-default clauses) and tightly binding the interests of creditors (through sharing clauses). For a discussion of these topics see Folkerts-Landau (1985).
} 


\section{Table 9. Structure of Developing Country Long-Term Debt} (In percent)

\begin{tabular}{|c|c|c|c|c|}
\hline & 1970 & 1982 & 1985 & 1988 \\
\hline All developing countries & 100.0 & 100.0 & 100.0 & 100.0 \\
\hline Public sector & 74.7 & 82.5 & 87.8 & 93.2 \\
\hline Official creditors & 51.3 & 35.5 & 38,0 & 45.2 \\
\hline Multilateral & 11.9 & 12.3 & 14.0 & 18.0 \\
\hline Bilateral & 39.4 & 23.1 & 24.0 & 27.2 \\
\hline Private creditors & 23.4 & 47.1 & 49.9 & 48.0 \\
\hline Commercial banks & 6.3 & 33.0 & 36.0 & 33.5 \\
\hline Bonds & 4.9 & 3.6 & 4.2 & 4.8 \\
\hline Other & 12.2 & 10.5 & 9.7 & 9.7 \\
\hline Private sector & 25.3 & 17.5 & 12.2 & 6.8 \\
\hline \multicolumn{5}{|l|}{ Memorandum item } \\
\hline Total commercial banks & 31.6 & 50.4 & 48.1 & 40.4 \\
\hline Severely indebted middle-income countries & 100.0 & 100.0 & 100.0 & 100.0 \\
\hline Public sector & 57.1 & 76.1 & 84.7 & 92.1 \\
\hline Official creditors & 28.4 & 17.9 & 23.2 & 30.9 \\
\hline Multilateral & 9.7 & 7.1 & 8.1 & 12.0 \\
\hline Bilateral & 18.7 & 10.8 & 15.1 & 19.0 \\
\hline Private creditors & 28.7 & 58.2 & 61.5 & 61.2 \\
\hline Commercial banks & 12.3 & 44.8 & 50.0 & 50.0 \\
\hline Bonds & 5.6 & 6.1 & 4.8 & 4.4 \\
\hline Other & 10.8 & 7.4 & 6.7 & 6.8 \\
\hline Private sector & 42.9 & 23.9 & 15.3 & 7.9 \\
\hline \multicolumn{5}{|l|}{ Memorandum item } \\
\hline Total commercial banks & 55.2 & 68.7 & 65.3 & 57.9 \\
\hline Low-income countries & 100.0 & 100.0 & 100.0 & 100.0 \\
\hline Public sector & 95.8 & 94.0 & 94.9 & 96.9 \\
\hline Official creditors & 83.7 & 65.7 & 65.6 & 64.9 \\
\hline Multilateral & 15.3 & 22.4 & 25.6 & 26.7 \\
\hline Bilateral & 68.4 & 43.3 & 39.9 & 38.2 \\
\hline Private creditors & 12.1 & 28.4 & 29.3 & 32.0 \\
\hline Commercial banks & 0.5 & 14.1 & 13.2 & 16.7 \\
\hline Bonds & 3.7 & 0.6 & 1.8 & 3.2 \\
\hline Other & 7.9 & 13.6 & 14.3 & 12.2 \\
\hline Private sector & 4.2 & 6.0 & 5.1 & 3.1 \\
\hline \multicolumn{5}{|l|}{ Memorandum item } \\
\hline Total commercial banks & 4.7 & 20.0 & 18.3 & 19.7 \\
\hline
\end{tabular}

Source: World Bank, World Debt Tables 1989-90.

developing countries ( 69 percent), but it had also become a substantial fraction ( 20 percent) of the debt of low-income developing countries. After 1982 , against the background of high real interest rates and deteriorating terms of trade combined with lax domestic policies and a severe curtailment of new lending, a number of major developing country borrowers experienced debt-servicing difficulties and became ensnared in repeated bank debt rescheduling and concerted new money exercises. These countries lost access to voluntary mediumterm bank loans as well as to securities markets, even though they generally continued to service their international bonds-a small share of their total debt-on a timely basis. The contagion did not extend, however, to those highly indebted develop- ing countries-including Hungary, India, Indonesia, Korea, Malaysia, Thailand, and others-that had maintained more prudent policies and timely debt servicing.

As a whole, spontaneous medium- and long-term bank credit commitments to developing countries fell from $\$ 42$ billion in 1982 to an average of $\$ 14$ billion a year in 1983-88. And while the nominal amount of funds raised through publicized international bond issues by developing country borrowers rose from an average of $\$ 3.5$ billion a year in 1977-81 to a range of $\$ 4-5$ billion a year in 1982-88, this represented a sharp decline in their share of total international issues. By 1988, the share of commercial banks in long-term external debt had fallen to around 40 percent for developing 
Table 10. Long-Term Bank Credit Commitments to Developing Countries, 1984-90 (In billions of U.S. dollars)

\begin{tabular}{|c|c|c|c|c|c|c|c|}
\hline & 1984 & 1985 & 1986 & 1987 & 1988 & 1989 & 1990 \\
\hline $\begin{array}{l}\text { Developing countries' } \\
\text { Of which: }\end{array}$ & \multicolumn{6}{|c|}{ Of which: } & 17.8 \\
\hline Spontaneous lending & 12.7 & 13.8 & 14.7 & 14.1 & 11.8 & 16.3 & 16.5 \\
\hline \multicolumn{8}{|l|}{ Of which: } \\
\hline Spontaneous lending & 11.6 & 12.2 & 13.3 & 14.0 & 11.5 & 14.9 & 16.5 \\
\hline Africa & 0.6 & 1.5 & 1.8 & 0.7 & 0.6 & 0.5 & 0.6 \\
\hline Asia & 9.4 & 7.5 & 8.2 & 8.5 & 7.8 & 8.9 & 10.7 \\
\hline Europe & 1.6 & 2.8 & 2.8 & 4.1 & 2.2 & 2.7 & 1.7 \\
\hline Middle East & 0.4 & 0.3 & 0.1 & 0.3 & 0.2 & 0.7 & 0.1 \\
\hline $\begin{array}{l}\text { Western Hemisphere } \\
\text { Of which: }\end{array}$ & 16.1 & 2.4 & 8.5 & 2.7 & 6.4 & 4.1 & 4.8 \\
\hline Spontaneous lending & 0.6 & 0.2 & 0.8 & 0.4 & 1.2 & $3.0^{2}$ & $3.5^{2}$ \\
\hline \multicolumn{8}{|l|}{ Memorandum items } \\
\hline Other countries ${ }^{3}$ & 1.9 & 3.5 & 2.1 & 1.5 & 2.5 & 1.5 & 3.0 \\
\hline Offshore banking centers & 0.9 & 0.4 & 0.7 & 0.3 & 0.4 & 2.4 & 3.0 \\
\hline
\end{tabular}

countries as a whole, and to 58 percent for the severely indebted middle-income developing countries. The share of bonds in total external debt of the severely indebted developing countries was around 4 percent in 1988, compared with 6 percent in 1982. The closure of the securities markets to developing countries experiencing debt-servicing difficulties during most of the 1980s sharply contrasted with the increasing role of these markets in intermediating payments imbalances in OECD countries.

Over the past two years, however, there have been some indications that borrowers from some developing countries that had experienced debtservicing difficulties were, after a long hiatus, beginning to regain access to spontaneous flows of private external funding. A substantial part of these new flows have been in the form of securities, marking a return to the historical pattern of capital flows. To date, new issues have been modest, and the phenomenon limited to a narrow range of countries-particularly Mexico, but also Chile, and Venezuela. This incipient process has featured a variety of financing techniques designed to take advantage of ongoing changes in international financial markets while addressing concerns among investors regarding the various risks and transaction costs involved in exposure to developing country borrowers.

\section{Recent Developments}

\section{Bank Lending}

Spontaneous bank credit commitments to capital importing developing countries (excluding offshore centers) rose to $\$ 16.5$ billion in 1990 from about $\$ 15$ billion in 1989; this represented an increase in the developing country share in total international bank credit commitments from about 12 to 14 percent (Tables 10 and A26 and A27). As in the recent past, the bulk of new syndicated bank loans (75 percent) went to developing countries in Asia and was project related. But there was also a notable, albeit modest, resumption in spontaneous bank lending to certain heavily indebted developing countries in Latin America that had rescheduled their debts and were pursuing adjustment programs.

The increase, from $\$ 3$ billion in 1989 to $\$ 3.5$ billion in 1990, in spontaneous bank commitments to Western Hemisphere countries conceals the noteworthy re-entry of some Latin American developing countries to voluntary bank lending markets. Spontaneous bank credit commitments to this region in 1989-90 included two large "semiconcerted" loans (\$1.6 billion in 1989 and $\$ 1.8$ billion in 1990) obtained by the government of $\mathrm{Co}$ lombia from its creditor banks to refinance principal payments falling due in the 1989-94 period (see 
Section VI). The 1989-90 data also include large loans ( $\$ 1.1$ billion in 1989 and $\$ 0.8$ billion in 1990) to multinational corporations based in Bermuda. Excluding these loans in 1990, the remaining spontaneous bank credit commitments to developing country borrowers in the Western Hemisphere went to such countries as Chile ( $\$ 0.3$ billion), Mexico ( $\$ 0.5$ billion), and Venezuela ( $\$ 0.2$ billion)-all heavily indebted countries, virtually excluded from the market for nearly a decade, that were involved in restructuring their debts and were implementing adjustment programs. These new credits were mostly project related and thus involved corporate borrowers, from the public as well as the private sectors, except in the case of a $\$ 20$ million loan made in September 1990 by a Dutch bank to Chile, the first fully voluntary, unsecured, sovereign bank loan to the Latin American region since 1982.

Bank commitments to developing countries in Central and Eastern Europe rose from $\$ 3.6$ billion in 1989 to $\$ 4.7$ billion in 1990 , reflecting large borrowings in 1990 by the Soviet Union ( $\$ 3$ billion, guaranteed by OECD governments) and Turkey (\$1.6 billion). ${ }^{94}$ By contrast, there were no new bank credit commitments in 1990 for other Central and Eastern European developing countries, including Hungary and Czechoslovakia, two countries that had continuously tapped the syndicated bank loan markets during the $1980 \mathrm{~s}$, as uncertainties surrounding the transition to market economies prompted international banks to avoid traditional, unsecured sovereign lending, while private structures to facilitate project lending were not yet in place. Bank credit commitments to African borrowers amounted to $\$ 0.6$ billion in 1990 , compared with $\$ 0.5$ billion in 1989 , and included a relatively large lease-related loan ( $\$ 0.3$ billion) to an Ethiopian airline and a number of smaller project-related loans to Ghana, Kenya, Morocco, and Zimbabwe. Commitments to Middle Eastern borrowers, by contrast, declined sharply to $\$ 0.1$ billion in 1990 , reflecting a one-off entry of Egypt to syndicated bank loan markets in 1989, when a publicly owned Egyptian airline company raised $\$ 0.5$ billion to finance the leasing of aircraft.

Average terms on spontaneous bank credit commitments to developing countries (excluding offshore centers and Central and Eastern European countries) showed a slight improvement in 1990 as compared with 1989 (Chart 13). Average spreads fell from 68 to 60 basis points and the average maturity increased from about 7 years to around 9 years (Tables 11 and A28). The improvement in

94 These figures include $\$ 1.5$ billion in 1989 and $\$ 3$ billion in 1990 in bank credit commitments to certain Eastern European countries classified under other countries in Table 10.
Chart 13. Terms on International Bank Lending Commitments, 1979-90

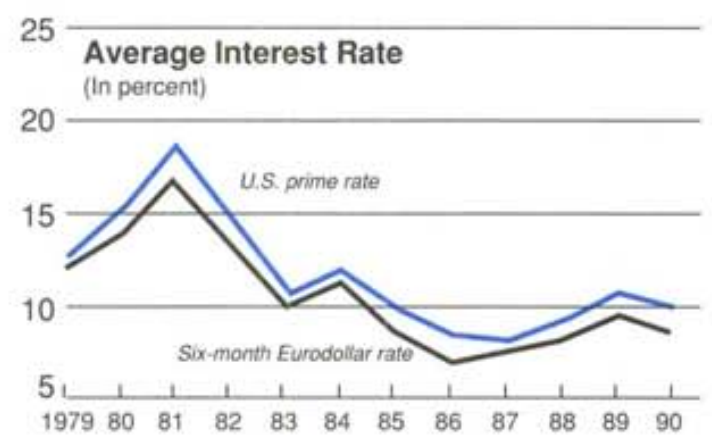

\subsection{Average Spreads \\ (In percent)}

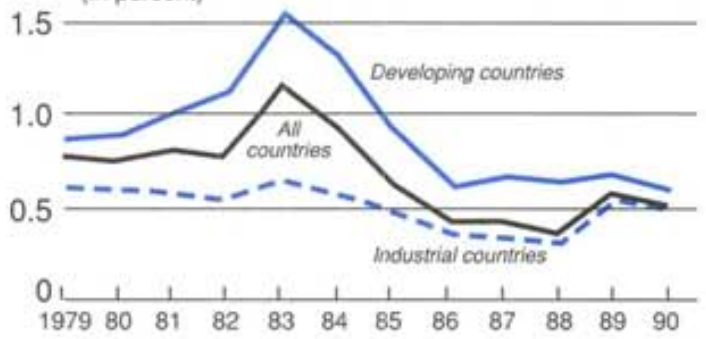

\section{Average Maturities'}
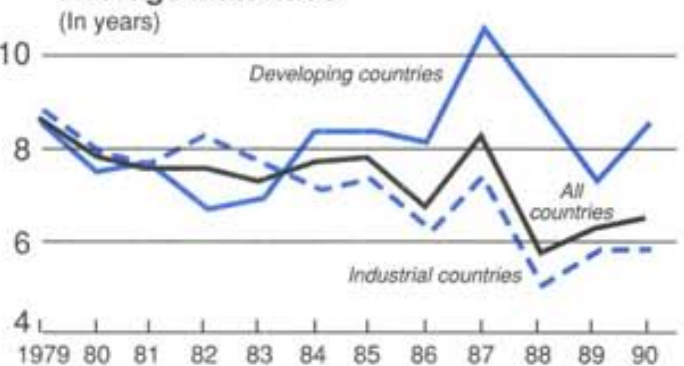

Sources: Organization for Economic Cooperation and Development, Financial Market Trends; International Monetary Fund, International Financial Statistics: and Fund staff estimates.

'New publicized long-term international bank credit commitments.

spreads largely reflected changes in the composition of borrowers, as certain relatively high-spread borrowers (e.g., Egypt, Kenya, Kuwait) that had tapped the syndicated bank loan market in 1989 did not do so during 1990. Likewise, the average maturity masks a wide dispersion in maturities across countries. Adjusting for changes in country compo- 
Table 11. Developing Countries: Terms on Syndicated Bank Credits, 1988-901

\begin{tabular}{|c|c|c|c|c|c|c|}
\hline & \multicolumn{2}{|c|}{1988} & \multicolumn{2}{|c|}{1989} & \multicolumn{2}{|c|}{1990} \\
\hline & Maturity & Spread & Maturity & Spread & Maturity & Spread \\
\hline & (In years) & $\begin{array}{l}\text { (In basis } \\
\text { points) }\end{array}$ & (In years) & $\begin{array}{l}\text { (In basis } \\
\text { points) }\end{array}$ & (In years) & $\begin{array}{c}\text { (In basis } \\
\text { points) }\end{array}$ \\
\hline $\begin{array}{l}\text { Average for develo } \\
\text { countries } \\
\text { Of which: }\end{array}$ & 8.9 & 57 & 7.3 & 68 & 8.6 & 60 \\
\hline Bahrain & 4.9 & 38 & 10.5 & 51 & 7.2 & 38 \\
\hline China & 8.5 & 50 & 9.3 & 53 & 9.8 & 61 \\
\hline Colombia & 10.0 & 94 & 11.8 & 87 & - & - \\
\hline Egypt & - & - & 10.0 & 113 & - & - \\
\hline Hong Kong & 5.2 & 69 & 4.6 & 31 & 4.4 & 62 \\
\hline India & 9.7 & 25 & 10.4 & 30 & 8.4 & 30 \\
\hline Indonesia & 7.4 & 56 & 7.0 & 95 & 9.3 & 78 \\
\hline Kenya & - & - & 1.0 & 75 & - & - \\
\hline Korea & 4.8 & 19 & 1.1 & 38 & 10.3 & 48 \\
\hline Kuwait & 3.5 & 113 & 4.0 & 88 & - & - \\
\hline Malaysia & 11.3 & 30 & 5.8 & 22 & 13.3 & 58 \\
\hline Oman & 8.8 & 58 & 8.0 & 45 & - & - \\
\hline Pakistan & - & - & 2.2 & 92 & - & - \\
\hline Thailand & 7.1 & 31 & 7.0 & 51 & 7.8 & 56 \\
\hline $\begin{array}{l}\text { Average for Easter } \\
\text { countries } \\
\text { Of which: }\end{array}$ & $\cdots$ & $\cdots$ & 8.3 & 49 & 11.9 & 50 \\
\hline Bulgaria & $\cdots$ & $\cdots$ & 7.0 & 40 & - & - \\
\hline Hungary & $\ldots$ & $\ldots$ & 8.8 & 53 & 8.0 & 82 \\
\hline Poland & $\ldots$ & $\ldots$ & 12.0 & 100 & - & - \\
\hline U.S.S.R. & $\ldots$ & $\ldots$ & 6.2 & 49 & 12.0 & 50 \\
\hline
\end{tabular}

sition between 1989 and 1990 , there appears to have been a general tendency for spreads on syndicated bank credits to increase while maturities tended to lengthen.

The incipient revival in spontaneous bank lending to developing countries that have experienced debt-servicing difficulties has in a number of cases been facilitated through the use of certain financing techniques-including leasing, loans linked to commodity prices, and price-hedging mechanisms. Examples include (i) the leasing arrangements by Egypt Air in 1989 and Ethiopian Airlines in 1990, where the corresponding loans were collateralized by a lien on the aircraft being leased; (ii) the borrowings by two Mexican copper companies (Mexicana de Cobre in July 1989 and Mexicana de Cananea in October 1990) hedged against the risk of adverse copper price movements through copper swaps and collateralized by long-term copper sales contracts; and (iii) the oil-indexed loan contracted by the Algerian petroleum company, Sonatrach, in early 1990 under which lenders benefit in terms of an increase in the spread over the London interbank offered rate (LIBOR) in the event of a sustained change in the price of oil.

\section{Portfolio Flows}

According to OECD data, publicized new bond issues by developing country borrowers (excluding those from offshore centers) rose somewhat from $\$ 4.5$ billion in 1989 to $\$ 5.1$ billion in 1990 . Given the sharp decline in bond issues worldwide, this represented an increase in the share of bond issuance by developing countries from 1.8 to 2.2 percent (Table 12). These data, however, understate total developing country borrowings through the bond markets particularly since private placements are not included. Information gathered from alternative sources (some of which is included in Table A29) suggests that the understatement may well exceed $\$ 1.5$ billion in 1990 . In any event, conditions for bond issuance by developing country borrowers appear to have tightened in the fourth quarter of 1990 , reflecting not only a general shift to shorter-term, more liquid, and lower-risk instruments following developments in the Middle East, but possibly also a degree of "market saturation" following a bunching of issues in the first three quarters of 1990.

As in previous years, Asian countries that had not 
Table 12. International Bond Issues by Developing Country Borrowers, 1984-901 (In millions of U.S. dollars)

\begin{tabular}{|c|c|c|c|c|c|c|c|}
\hline & 1984 & 1985 & 1986 & 1987 & 1988 & 1989 & 1990 \\
\hline Developing countries ${ }^{2}$ & $4,387.8$ & $8,113.3$ & $4,210.3$ & $3,711.4$ & $5,974.3$ & $4,515.3$ & $5,131.2$ \\
\hline \multicolumn{4}{|l|}{ Capital importing developing } & $3,711.4$ & $5,974.3$ & $4,515.3$ & $5,131.2$ \\
\hline $\begin{array}{l}\text { Africa } \\
\text { Algeria }\end{array}$ & $\begin{array}{r}1,013.9 \\
-\end{array}$ & $\begin{array}{r}1.322 .5 \\
500.0\end{array}$ & $\begin{array}{l}125.6 \\
125.6\end{array}$ & $\begin{array}{l}49.2 \\
49.2\end{array}$ & $\begin{array}{l}470.9 \\
433.3\end{array}$ & $\begin{array}{l}159.0 \\
159.0\end{array}$ & 35.5 \\
\hline South Africa & $1,013.9$ & 802.2 & - & - & 37.6 & - & 35.5 \\
\hline Tunisia & - & 20.3 & - & - & - & - & - \\
\hline Asia & $2,951.0$ & $6,005.4$ & $2,915.4$ & $2,410.8$ & 2.631 .1 & $2,217.9$ & $2,757.4$ \\
\hline China & 81.7 & 972.8 & $1,362.1$ & $1,415,2$ & 911.6 & 150.4 & - \\
\hline India & 297.6 & 417.8 & 323.2 & 377.0 & 714.6 & 668.3 & 623.0 \\
\hline Indonesia & 50.0 & - & 300.0 & 50.0 & 221.1 & 175.0 & 529.0 \\
\hline Korea & $1,056.0$ & $1,730.9$ & 783.0 & 332.3 & 130.0 & 328.2 & 1.355 .4 \\
\hline Malaysia & $1,141.2$ & $2,001.9$ & 43.0 & 215.6 & 360.7 & 428.5 & 200.0 \\
\hline Thailand & 283.3 & 861.7 & 50.0 & - & 261.0 & 231.7 & 50.0 \\
\hline Other & 41.2 & 20.3 & 54.0 & 20.7 & 32.1 & 235.8 & - \\
\hline Europe & 40.5 & 509.6 & 457.2 & 866.1 & $1,975.6$ & $2,138.4$ & $1,607.4$ \\
\hline Hungary & 40.5 & 447.1 & 290.5 & 554.6 & 816.2 & 942.6 & 946.9 \\
\hline Turkey & - & 62.5 & 166.7 & 311.5 & $1,159.4$ & $1,195.8$ & 660.5 \\
\hline Middle East & - & 82.0 & - & 35.0 & 20.0 & - & - \\
\hline Egypt & - & 60.0 & - & - & - & - & - \\
\hline Israel & - & 22.0 & - & 35.0 & 20.0 & - & - \\
\hline Western Hemisphere & 107.4 & 168.8 & 712.1 & 350.3 & 876.7 & - & 730.9 \\
\hline Argentina & - & - & - & 195.0 & - & - & - \\
\hline Barbados & - & 19.2 & 59.8 & - & 40.1 & - & 57.9 \\
\hline Brazil & - & - & 300.0 & - & - & - & - \\
\hline Colombia & - & - & 39.0 & 50.0 & - & - & - \\
\hline Mexico & - & 49.0 & 313.3 & - & - & - & 504.9 \\
\hline Trinidad and Tobago & 107.4 & 100.6 & - & 105.3 & 78.9 & - & - \\
\hline Venezuela & - & - & - & - & $757.7^{3}$ & - & 168.1 \\
\hline \multicolumn{8}{|l|}{ Memorandum items } \\
\hline Offshore banking centers & 285.6 & 383.3 & 568.7 & 228.0 & 285.1 & 199.0 & 75.0 \\
\hline Hong Kong & 185.6 & 58.3 & 325.9 & - & 204.5 & 74.0 & - \\
\hline Singapore & - & 155.0 & 242.8 & 228.0 & - & 125.0 & 75.0 \\
\hline Other & 100.0 & 170.0 & - & - & 80.6 & - & - \\
\hline \multicolumn{8}{|l|}{ Other countries ${ }^{4}$} \\
\hline Bulgaria & - & - & - & - & 81.8 & 329.9 & - \\
\hline Czechoslovakia & - & - & - & - & 129.5 & 74.0 & 376.6 \\
\hline U.S.S.R. & - & - & - & - & 333.2 & 891.5 & 297.6 \\
\hline \multicolumn{8}{|c|}{$\begin{array}{l}\text { Source: Organization for Economic Cooperation and Development, Financial Statistics Monthly. } \\
\text { 'Foreign bonds and Eurobonds. Excludes bonds issued in the context of commercial bank debt restructuring and financing agreements. } \\
\text { 'Excludes offshore banking centers. } \\
\text { 'Includes } \$ 500 \text { million of sovereign bonds placed on a voluntary basis with commercial bank creditors, in exchange for } \$ 400 \text { million of } \\
\text { restructured bank debt and } \$ 100 \text { million of fresh money. } \\
{ }^{4} \text { Not included in the developing country category. }\end{array}$} \\
\hline
\end{tabular}

rescheduled their debts accounted for the bulk of new bond issues by developing countries in 1990, raising $\$ 2.8$ billion or more than one half of the developing country total. The most active Asian issuers in 1990 included corporate borrowers from Korea, India, Indonesia, and Malaysia. International bond issues by borrowers from Central and Eastern European developing countries fell from $\$ 3.4$ billion in 1989 to $\$ 2.3$ billion in 1990 . The main borrowers in 1990 included public or quasi- public institutions from Hungary, Turkey, Czechoslovakia, and the Soviet Union. The Hungarian borrowings included a Eurodollar bond issue by the State Development Bank enhanced by a principal guarantee extended by the World Bank under its newly established Expanded Cofinancing Operations (ECOs) program. The reduced use of bond markets by Eastern European developing countries reflected, in part, the withdrawal of Bulgaria from these markets, following the emergence of debt- 
Table 13. Average Terms on International Bond Issues by Selected Developing Country Borrowers

\begin{tabular}{|c|c|c|c|c|c|c|c|c|c|c|c|c|c|c|c|c|}
\hline & \multicolumn{8}{|c|}{1989} & \multicolumn{8}{|c|}{1990} \\
\hline & \multicolumn{2}{|c|}{ I } & \multicolumn{2}{|c|}{ II } & \multicolumn{2}{|c|}{ III } & \multicolumn{2}{|c|}{ IV } & \multicolumn{2}{|c|}{ I } & \multicolumn{2}{|c|}{ II } & \multicolumn{2}{|c|}{ III } & \multicolumn{2}{|c|}{ IV } \\
\hline & $M$ & $\bar{P}$ & $M$ & $\overline{\mathbf{p}}$ & $\mathrm{M}$ & $\vec{P}$ & $M$ & $\bar{P}$ & $M$ & $\bar{P}$ & $M$ & $\bar{P}$ & $M$ & $\bar{P}$ & $\mathrm{M}$ & $P$ \\
\hline \multicolumn{17}{|l|}{ New entrants } \\
\hline $\begin{array}{l}\text { Secured issues } \\
\text { Unsecured issues }\end{array}$ & $\cdots$ & $\ldots$ & $\ldots$ & $\ldots$ & $\cdots$ & $\cdots$ & 5.0 & 160 & 4.7 & 360 & 2.8 & 320 & 4.6 & 280 & $\ldots$ & $\ldots$ \\
\hline Public sector & $\ldots$ & $\ldots$ & 5.0 & 870 & $\ldots$ & $\ldots$ & $\ldots$ & & 5.0 & 250 & 7.5 & 420 & 3.6 & 380 & 3.8 & 350 \\
\hline Private sector & $\ldots$ & $\ldots$ & $\ldots$ & $\ldots$ & $\ldots$ & $\ldots$ & 2.0 & 800 & $\ldots$ & $\ldots$ & 2.0 & 730 & 3.0 & 600 & 5.0 & 600 \\
\hline \multicolumn{17}{|l|}{ Venezuela } \\
\hline $\begin{array}{l}\text { Secured issues } \\
\text { Unsecured issues }\end{array}$ & $\cdots$ & $\ldots$ & $\ldots$ & $\ldots$ & $\ldots$ & $\ldots$ & $\ldots$ & $\ldots$ & $\ldots$ & $\ldots$ & $\ldots$ & $\ldots$ & $\ldots$ & $\ldots$ & 5.5 & 250 \\
\hline Public sector & $\ldots$ & $\ldots$ & $\ldots$ & $\ldots$ & $\ldots$ & $\ldots$ & $\ldots$ & $\ldots$ & $\ldots$ & $\ldots$ & & & 5.0 & 260 & $\ldots$ & $\ldots$ \\
\hline Private sector & $\ldots$ & $\ldots$ & $\ldots$ & $\ldots$ & $\ldots$ & $\ldots$ & $\ldots$ & $\cdots$ & $\cdots$ & $\ldots$ & 5.0 & 730 & 5.0 & 650 & $\cdots$ & $\cdots$ \\
\hline \multicolumn{17}{|c|}{ Other selected borrowers } \\
\hline Algeria (public secto & & & & & & & & & & & & & & & & \\
\hline unsecured) & $\cdots$ & ... & 5.0 & 120 & 5.0 & 180 & $\cdots$ & $\cdots$ & 5.0 & 100 & $\cdots$ & $\cdots$ & $\cdots$ & $\cdots$ & $\cdots$ & $\ldots$ \\
\hline \multicolumn{17}{|c|}{ Hungary (public sector) } \\
\hline Secured issues & $\ldots$ & $\ldots$ & & $\ldots$ & & & & $\ldots$ & & $\ldots$ & $\ldots$ & & 10.0 & 190 & & $\ldots$ \\
\hline Unsecured issues & 6.0 & 70 & 8.0 & 120 & 7.0 & 230 & 7.0 & 90 & 7.0 & 140 & 6.0 & 130 & 5.0 & 90 & 5.6 & 140 \\
\hline $\begin{array}{l}\text { India (public sector/ } \\
\text { unsecured) }\end{array}$ & 10.0 & 160 & 7.0 & 160 & $\cdots$ & $\cdots$ & 5.0 & 90 & 7.0 & 160 & 7.0 & 100 & $\cdots$ & $\ldots$ & $\cdots$ & $\ldots$ \\
\hline $\begin{array}{l}\text { Turkey (public sector } \\
\text { unsecured) }\end{array}$ & 8.0 & 140 & 10.8 & 220 & 8.5 & 160 & $\ldots$ & $\ldots$ & 7.0 & 230 & 7.0 & 50 & 5.0 & 190 & $\ldots$ & $\ldots$ \\
\hline
\end{tabular}

servicing difficulties, and, more generally, international investors' heightened concern regarding the risks of major economic transitions, concern reflected in the downgrading of the debt instruments of a number of Eastern European countries by credit rating agencies.

A significant development in developing country access to international bond markets in the past two years was the limited re-entry, after almost a decade, of certain Latin American countries that have embarked on programs of economic adjustment and debt restructurings. This re-entry was led by Mexican public and private sector corporations that began re-entering international bond markets starting in late 1988. In 1990, Venezuelan corporations also began using these markets. While most of the issues by Mexican and Venezuelan corporations were denominated in U.S. dollars, the deutsche mark and Austrian schilling markets were also tapped. According to OECD data, and excluding sovereign bonds associated with restructurings, Mexican and Venezuelan borrowers raised $\$ 0.5$ billion and $\$ 0.2$ billion, respectively, on a voluntary basis during 1990 through publicized bond issues. Alternative sources, which include private placements (Table A29), put the amount of new bond issues in 1990 at $\$ 2.2$ billion for Mexican borrowers and \$0.3 billion for Venezuelan borrowers. The limited restoration of spontaneous access to bond markets for these countries has mainly benefited corporations with established international reputations and export bases and was facilitated in a number of cases by the use of collateralization techniques described further below.

Average terms on unsecured developing country bond issues included a wide range of premiums over "risk-free" rates (Table 13). ${ }^{95}$ For instance, premiums on 1990 bond issues by Mexican public sector corporations ranged between 250 and 420 basis points, significantly higher than those paid by sovereign borrowers from Hungary (100-140 basis points), India (100-160 basis points), or Turkey

95 Rates on bond issues by the major industrial countries are used as a proxy for the theoretical risk-free rate. 
(50-230 basis points), but substantially lower than premiums in the $600-700$ basis point range on unsecured issues by Mexican or Venezuelan private sector corporate borrowers. Even these latter premiums have tended to be somewhat lower than those implied in secondary market prices for the old syndicated bank debt of the respective governments. While maturities on issues by new entrants remained on the short-term range (five years or less) during 1989-90, maturities on issues by certain established developing country borrowers (e.g., Hungary and Turkey) tended to decrease toward this range in 1990. The tightening of bond market conditions for developing country borrowers in the fourth quarter of 1990 was mainly reflected in a virtual halt of new issues, rather than a combination of higher premiums and shorter maturities.

Equity portfolio flows to developing countries take various forms, including foreign purchases of shares in a developing country corporation directly in the local stock market; developing country corporate equity issues in developed country stock markets; or indirect foreign purchases of shares in developing country corporations, through, for example, "country funds" that specialize in investing in emerging developing country stock markets. Published aggregate statistics on these types of flows are unavailable, but a broad idea of the orders of magnitude may be obtained on the basis of partial information. A study by the World Institute for Development Economics Research (WIDER) estimated the market value of the stock of nonresident portfolio equity investments in emerging markets at the end of 1989 at around $\$ 15$ billion, comprising about $\$ 8$ billion in assets held by country specific or multicountry funds and about $\$ 7$ billion invested in equity of developing country corporations issued either in developed stock exchanges or in local developing country markets. ${ }^{96}$ These investments, which constituted about 2 percent of foreign equity holdings in institutional portfolios of OECD countries, have been concentrated in Taiwan Province of China, Korea, India, Indonesia, Malaysia, the Philippines, and Thailand, although equity investments into certain Latin American countries (particularly Chile and Mexico) and some Eastern European countries (particularly Hungary) have increased recently.

Gross foreign portfolio equity flows into emerging markets are estimated to have averaged about $\$ 1$ billion a year during the past four years, again largely concentrated on Asian developing countries. Mainly as a result of substantial declines in share prices in certain emerging stock markets dur-

96 World Institute for Development Economics Research (1990). ing 1990, the market value of the developing country stocks held by foreign portfolio investors fell sharply in $1990 .{ }^{97}$ Country-specific or multicountry funds have been an important vehicle for equity portfolio flows to emerging markets. The gross initial size of each fund has normally been in the $\$ 50-150$ million range. By late 1990 , there were over 100 closed-end publicly offered countryspecific and regional funds for investment in emerging markets and at least an equal number of openend and privately placed closed-end funds. In the second half of 1989 and early 1990, a rapidly increasing number of country-specific and regional funds were launched, and a large number rose to very high premiums over net asset value. A situation of oversupply consequently emerged during the course of 1990 and, as share prices for most funds declined, investor interest was considerably reduced. At the same time, sophisticated portfolio managers appear to have increasingly bypassed country funds and invested directly in the more open emerging markets. The fall in the Tokyo stock market exacerbated matters as Japanese investors sold country fund shares in order to meet margin calls. The void left by the withdrawal of Japanese investors was not filled by other international investors, partly in reflection of the portfolio shifts associated with the Middle East crisis. By the fourth quarter of 1990 , most country funds were trading at substantial discounts relative to net asset value and new issues had come to a virtual halt.

Despite the slowdown in new issues of country funds during 1990, resources raised by such funds for investment in emerging markets for the year as a whole are estimated to have been in the \$1.5-2 billion range, including around $\$ 1$ billion raised for investment in Eastern Europe but not fully deployed in the region. During the year, some developing country corporations also raised new foreign financing, albeit in very modest amounts, through equity securities issued in industrial country stock exchanges. For instance, in April the Hungarian state-owned travel agency and tour operator, IBUSZ, became the first Eastern European company simultaneously to place shares in Western developed markets and the recently opened $\mathrm{Bu}$ -

\footnotetext{
97 According to the International Finance Corporation's (IFC) Emerging Stock Market Data Base, during the 12-month period ended December 1990, total return indices (measured in U.S. dollar terms) declined sharply in Brazil (68 percent), the Philippines (52 percent). Taiwan Province of China (51 percent), Argentina ( 38 percent), Portugal (34 percent), and Korea (27 percent). Total return indices of some markets, however, rose significantly, including Venezuela, (556 percent), Greece ( 88 percent), Chile ( 31 percent), Colombia ( 26 percent), Mexico (25 percent), and India (16 percent). These performances may be compared with a 6 percent decline in the S\&P 500 over the same period.
} 
dapest exchange. The international-tranche issue, listed in the Vienna stock exchange, reportedly raised around $\$ 7$ million. In June, the privatization of Poland's Foreign Trade Enterprises, known as "Universal," involved the flotation of \$20 million in equity issues, of which $\$ 6.6$ million was made available to foreign investors on a private placement basis. In July, there was a public equity offering by the Chilean privately owned telephone company, CTC, which raised $\$ 98.3$ million $(\$ 90.5$ million net of commissions and other costs) through the issue of American Depository Receipts (ADRs) on the New York Stock Exchange-reportedly the first international public equity offering by a Latin American corporation since 1963.

Foreign portfolio investors have also acquired equity participations in developing country corporations in the context of privatization programs. During the past two years, the privatization programs in a number of developing country (e.g., Argentina, Chile, Indonesia, Malaysia, Mexico, and the Philippines) have involved flotations of shares accessible to nonresident portfolio investors either because some of these shares have been issued and placed in industrial country securities markets (as in, for instance, the privatization of Telmex, the Mexican telephone company) or, more commonly, because the shares issued in the local developing country market have been available to nonresident investors, either directly or through a country fund. In some cases, as discussed previously, privatization programs have allowed investors to swap eligible external debt for privatization shares at a discount. It should be noted, however, that debt-equity swaps represent a change in the composition of nonresident claims on developing countries and thus do not entail of themselves a net inflow of fresh financing to developing countries. In effect, owing to such potential problems as roundtripping and lack of "additionality," debt-equity swaps may even entail net foreign exchange outflows.

\section{Re-Entry to Capital Markets: Addressing Investor Concerns}

Investors holding claims on developing country borrowers must be in a position to evaluate the risks involved; they must assess the risk of default (counterparty credit risk) and the risk that a government may not make foreign exchange available to the borrower to meet his debt-servicing obligations (country transfer risk). Investors must also consider the ease with which the claim is likely to sell at a quoted price should they wish to dispose of it before maturity (liquidity risk). Availability of information is critical to this evaluation process. In the absence of sufficient information, lenders may not be able to price the instrument offered by the borrower and would not accept it even if the borrower were willing to pay a very high premium. Investors' willingness to acquire new debt claims may in fact decline in response to very high-premium offers, because such offers may reasonably be interpreted as a sign of actual or impending financial weakness. Consequently, for re-entry to take place, investors' concerns must be addressed in a way that would not only make pricing possible, but would also bring prices to a range where new borrowing is a realistic possibility.

\section{Counterparty Credit Risk and Country Transfer Risk}

In the case of a sovereign borrower, where there is no intermediary that can restrict payments, there is, in effect, no "transfer risk," but counterparty credit risk remains. Corporate credit risk is familiar terrain for investment analysts, who can base their assessments on balance sheets, cash flow positions, business prospects, and quality of information. Country transfer risk is more difficult to assess, since it depends on the government's ability to marshal resources, which is a function of a host of economic, social, political, and other factors subject to large uncertainties and not always amenable to measurement.

During the 1970s, it was sometimes argued that country transfer risk was negligible because "countries do not go bankrupt." Behind this opinion was the perception, not entirely unfounded, that debtor countries and their bank creditors could count on official reserves if debt-servicing difficulties posed a serious threat to the integrity of the system. This view was, of course, progressively modified in light of the experience of the 1980 s, and careful, if still problematic, assessments of country transfer risk have become relatively formalized. These assessments, increasingly quantitative, tend to give significant weight to selected economic variables but also take into account political factors.

The assessments by international credit rating agencies, often a key input in portfolio investors' decisions, illustrate the prominence given to transfer risk. Moody's Investors Service, for instance, in evaluating the risk of a particular international bond issue, considers separately the individual counterparty credit risk and the more general country transfer risk; the final overall rating, however, follows a "sovereign ceiling rule" whereby no international bond issuer can be rated above the sovereign rating given to the country where the borrower operates. Moody's thus takes the view that, although a nonsovereign entity may for various reasons be able to honor its obligations better than its government 
over a given period of time, it is in general not possible to insulate a borrower consistently and over a long period of time from the sovereign risk of its home country. ${ }^{98}$ Some form of a sovereign ceiling rule seems to be widely accepted by market participants. In effect, the international bond issues by major OECD governments set a benchmark cost of funds rate for their country, with other borrowers from the same country normally having to pay a premium above this rate. A somewhat greater variance of market views seems to exist, however, when it comes to developing country borrowers, partly because there are a number of private sector companies from developing countries that have, over the past decade, established a better track record of external debt servicing than their governments.

The good debt-servicing record of a number of private sector companies in developing countries reflects, inter alia, the flexibility with which these companies have adapted to changed economic conditions; and an improved policy environment in many developing countries associated with a reduced readiness on the part of the respective governments to resort to foreign exchange restrictions to deal with balance of payments problems. Even in cases where quantitative restrictions on access to foreign exchange at the official rate have been present, governments have in a number of cases allowed unrestricted access to flourishing parallel markets, which have been used as necessary by private sector debtors to remain current on their obligations. Such developments in some cases seem to have relaxed market perceptions of rigid linkages between country transfer risk and the counterparty credit risk of an individual developing country corporate borrower. This may in part explain the fact that some private sector companies from developing countries have recently been able to raise funds through unsecured international bond issues at somewhat lower yields than those implicit in the secondary market prices for the syndicated bank debt of their respective governments. Nonetheless, concerns among investors regarding country transfer risk continue to be crucial and need to be addressed by developing country borrowers entering international capital markets. There are a number of ways in which country transfer risk may be reduced.

\footnotetext{
98 Other international rating agencies include Standard \& Poor's and Political Risk Services (PRS). The latter specializes in country risk assessments for less creditworthy countries that are not normally rated by Standard \& Poor's and Moody's. PRS calculates medium-term country ratings based on four equally weighted factors: capital repatriation regulations, export payment delays, fiscal and monetary policies, and external indebtedness.
}

At the most fundamental level, it is widely recognized that there is no substitute for sustained implementation of sound macroeconomic policies and structural reforms if a lasting reduction of country transfer risk is to be achieved. The maintenance of a realistic exchange rate, the restoration of fiscal and monetary discipline, movements in real wages that are not grossly misaligned with productivity increases-all are crucial to re-establish business confidence and develop a strong export base and debt-servicing capacity. The salutary effects of sound macroeconomic policies, however, may take time to materialize, especially where the shift toward better policies follows a period of economic mismanagement that has seriously undermined a government's credibility. A wait-and-see attitude may in effect be the response from investors, even while sound macroeconomic policies are being implemented.

Decisive, significant steps in structural reforms can play a crucial role in reducing these remaining uncertainties, provided that macroeconomic adjustment policies continue to hold a steady course. Concrete progress in key structural reforms provides evidence of a government's political capacity to overcome entrenched interests and replace outmoded and inefficient structures. Reforms that more closely integrate tradable sectors to the world economy, such as liberalization of the exchange, trade, and direct investment systems, can have particularly beneficial effects on reducing investor perceptions of transfer risk. Integration in effect raises efficient productive capacity and debt-servicing capacity, while increasing the economic and political cost of subsequently imposing restrictions on external payments and flows. Progress in the reform process itself would be expected to strengthen supportive political constituencies, thus lowering the risk that new policies would be reversed.

The perception of country transfer and sovereign risk on new flows may also be reduced through the restructuring of existing debt obligations. Where a debtor country faces a severe liquidity crisis, new lenders would resist providing fresh money. In this case, agreements with existing creditors on debt rescheduling or refinancing, which would require a concerted approach since incentives to free rides exist, could provide the "breathing space" needed to implement adjustments and thus pave the way for new lending. In cases where a more serious solvency problem exists, elements of debt and debtservice reduction would need to be included in restructuring agreements if country transfer risk is to be reduced. Solvency is at issue where there is a widespread market perception that a sovereign debtor's capacity to pay (i.e., its discounted stream of expected income available for debt servicing) falls short of its contractual debt obligations (mea- 
sured in present value terms). This problem (often referred to as debt overhang) is likely to complicate the implementation of adjustment policies owing to, for instance, the vulnerability of the fiscal position to external shocks.

Also, in view of the limitations of informal subordination mentioned earlier, this problem would represent a major obstacle for the resumption of new lending and the recovery of investment, as lenders and investors-foreign and domesticwould fear that their new claims on the country's resources would not be given priority relative to old debt contracts. ${ }^{99} \mathrm{By}$ including elements of debt and debt-service reduction where appropriate, restructuring agreements would, in combination with sound domestic policies, help ease the constraints on adjustment, investment, and new lending, thus raising the country's capacity to pay and reducing transfer risk. Experience with recently implemented bank debt packages suggests that these packages may have immediate favorable effects on confidence and, therefore, on risk premiums.

The perception of transfer risk may be reduced for certain classes of debt by giving give them an effective payment priority and excluding them from rescheduling exercises. Well-established, fully enforceable seniority arrangements do not exist for international contracts involving sovereign risk and subordinating old syndicated bank credit has been difficult, but developing countries experiencing payments difficulties have at times succeeded in protecting their access to flows vital to their economies, such as trade and interbank credit, by giving them priority in servicing. On balance, however, commercial bank debt workouts have been much less effective in protecting new flows than official debt reschedulings under the aegis of the Paris Club, which have strictly adhered to the principle that debts contracted after a cut-off date agreed to at the time of the first rescheduling would not be subject to subsequent reschedulings. This principle has been essential to the maintenance of access to new official bilateral loans, including credit and guarantees from official export credit agencies.

Market participants have often noted that it has been difficult to raise new commercial bank loans, including loans to heavily indebted countries now regaining access to other segments of international markets, because of a perceived lack of flexibility in creditor countries' provisioning requirements. ${ }^{100}$

99 The disincentive effects of excessive debt burdens on new lending and investment have been discussed at length elsewhere. See, for instance, Frenkel and others (1989).

100 While specific provisioning regulations vary from country to country, average bank provisioning levels against problem country exposure exceeds 50 percent in all of the main banking center countries except Japan. Further information on
In many cases (e.g., Belgium, Canada, Japan, and the Netherlands), these provisioning requirements have been specifically triggered by debt-servicing difficulties as reflected in payments arrears or debt rescheduling, and regulations typically specify that provisions must be maintained for at least five years after the most recent rescheduling agreement. In other cases (e.g., Germany, the United Kingdom, and the United States), a recent rescheduling or an episode of arrears would be a factor justifying a presumption that provisions would be necessary. As a general rule, regulatory authorities will clearly be cautious about reducing provisioning levels on debtors whose performance has improved, at least until it can be demonstrated that the improvement is not temporary. Nevertheless, regulatory authorities in a number of countries do provide some flexibility in such cases. In Canada, for example, the Superintendent of Financial Institutions may remove a country from the provisioning list two years, rather than the normal five years, after the most recent rescheduling, if the country has demonstrated its ability to raise spontaneous, unsecured financing with a maturity exceeding one year on international capital markets.

While it can be expected that provisioning requirements will ease only slowly, it should be noted that loan classes with superior debt-servicing records-such as short-term trade credits, cofinancing, or credits with third-party guarantees-are in some countries specifically exempted from provisioning requirements. In the United States, for example, specific provisions (Allocated Transfer Risk Reserves-ATRRs) are established by regulators on particular claims that are classified as value impaired and are not required on claims that continue to be serviced in full and would not necessarily be required on new money if there were a presumption that such claims would be serviced. Despite the limitations in credibly privileging new flows through differential payments policies, however, secondary market prices for developing country debt have reflected perceptions of differential payments priorities. For instance, in December 1990 , the average yield to maturity on Venezuela's restructured bank debt was about 17.5 percent compared with 13 percent on its sovereign (nonrestructured, nonconcerted) floating rate notes; the yield to maturity on Argentina's syndicated bank debt was about 40 percent, compared with 23 percent on its sovereign bonds and about 21 percent on its Trade Credit Deposit Facility; and the average yield to

national regulatory frameworks is contained in International Monetary Fund, International Capital Markets (1990), Section V. 
maturity on Mexico's restructured bank debt was 18.5 percent, compared with around 14 percent on interbank credits. This tiered pricing is considered to have made room for some of the new unsecured issues by corporate developing country borrowers at comparatively favorable yields.

Country transfer and counterparty credit risks, as well as risk premiums, can also be substantially reduced through various collateralization techniques, which provide a lender with the right to take possession of certain specified assets if the borrower fails to pay. The collateral pledged to secure a claim may be a physical good or a document that gives the claim holder the right to payments or assets. Investors generally expect pledged assets to meet certain basic conditions: easily ascertainable market value, an understood structure, and uncomplicated and certain procedures for disposal. Assets that meet these conditions and have been used by developing country borrowers to remove or reduce transfer risk include income streams generated overseas, liquid assets (such as bank deposits, securities, or precious metals) located overseas, and physical assets used outside the country (such as boats or aircraft). The recent use of collateralization by developing country borrowers that are new entrants to the international capital markets has mainly involved private sector corporate borrowers or public sector corporations raising debt without explicit guarantees from their central governments. Recent borrowing by the Mexican telephone company provide an illustration of collateralization and its effects.

In March 1990, Telefonos de Mexico (Telmex), which was then not yet privatized, raised $\$ 280$ million at an initial yield of 11 percent through a privately placed 5-year bond issue secured by a lien on its accounts receivable from a U.S. telephone company. Since the telephone traffic patterns between Mexico and the United States are such that the U.S. telephone company was expected to owe Telmex upward of $\$ 1$ billion a year for the foreseeable future, the principal risk to the investor was the risk that the U.S. company would refuse to pay Telmex and Mexican transfer risk was thus virtually eliminated. The initial yield on the Telmex collateralized issue was about 320 basis points above the yield then prevailing on 5-year U.S. Government bonds, which may be compared with an initial yield of about 475 basis points over the yield on U.S. Government bonds paid on the company's unsecured July 1990 issue ( $\$ 150$ million, 1.5-year maturity).

It needs to be noted that there are limitations on the use of collateralization to secure new borrowings. First is the issue of potentially reduced seniority (subordination) for creditors with unsecured claims; pledging assets that could be used to service any obligation in effect raises the risk of loss for such creditors. ${ }^{101}$ A related limitation of collateralization is its potential effect on a borrower's prospects for future market access on an unsecured basis. By unduly encumbering its assets through liens, a borrower may significantly raise the cost at which it could raise such funds. Finally, where valuation of assets is not straightforward, debtors may overpay to get liquidity and deprive themselves of future flexibility. In all, it is doubtful that collateralization techniques could mobilize on a sustained basis substantial new inflows to developing countries. At times, however, such techniques may serve a useful purpose, especially for nonsovereign borrowers that are new entrants to international capital markets.

Country transfer risk can also be reduced through explicit third party guarantees (or insurance) attached to developing country borrowings. The value of the guarantee to an investor is related mainly to the degree and type of coverage as well as to the creditworthiness of the guarantor. The degree to which the guarantor exposes itself to risk is not only dependent on the coverage of the guarantee but also on the extent to which the guarantor enjoys such advantages vis-à-vis other claim holders as seniority, better capacity to collect payments, or superior knowledge of the borrower. Explicit guarantees by multilateral institutions or official OECD governments have the greatest value for private investors or bank creditors. Prominent examples include cover provided by official export credit and insurance agencies, and by explicit guarantees or insurance provided by multilateral institutions (e.g., the World Bank's Expanded Cofinancing Operations, International Finance Corporation, and Multilateral Investment Guarantee Agency). Terms and conditions for guarantees or insurance provided by official export credit agencies are determined on a case-by-case basis. Cover may be available for short- and medium-term export-related credits extended by either an exporter (suppliers' credit) or a commercial bank, but export credit agencies have tended to concentrate on middle-income developing countries that have averted payments difficulties or to some developing countries experiencing debtservicing difficulty but implementing sustainable policies. According to unpublished data compiled by the OECD, new commitments to provide medium- and long-term cover to developing countries in 1988 totaled $\$ 25.4$ billion, which may be

101 Negative pledge clauses in loan contracts are the main legal device used by lenders to reduce this risk of subordination through collateralization in new loan contracts. Through negative pledge clauses, a lender may block any pledge of collateral on a new contract, except if the debtor offers him a comparable security. Other borrowing vehicles, like leases on particular capital goods, can sometimes offer an alternative. 
compared with $\$ 11.8$ billion in medium- and longterm spontaneous bank credit commitments to developing countries (excluding offshore centers) in that year. On balance it appears that in recent years officially supported export credits to developing countries have been significantly greater than nonguaranteed export financing from commercial banks. ${ }^{102}$

\section{Liquidity Risks and Transaction Costs}

A key consideration for an investor assessing an asset's attractiveness is its liquidity, that is, the degree to which the asset can be bought and sold readily at prevailing market prices. The liquidity of securities issued by industrial country borrowers varies widely, from bond issues of national governments and equity claims on major corporations at one end of the scale-for which markets are normally deep and transaction costs low-to more speculative stocks and bonds of smaller or new companies for which markets may be much thinner. Securities issued by borrowers from developing countries typically fall at the latter end of the spectrum. Issues are usually small in scale, particularly for borrowers other than the government and the largest parastatal enterprises, while domestic capital markets are thin and underdeveloped. Foreign investors, therefore, face the prospect that transactions that are small in relation to the size of their own portfolios may nevertheless be large relative to the market. Moreover, transaction costs and risks incurred through clearance and settlement procedures in local markets may be relatively high. In combination, these factors may provide strong disincentives for investment in instruments issued by developing country borrowers.

A number of techniques have been used to try to address these difficulties. One approach is to place and trade securities directly on an established exchange outside the country of the issuer, a fairly common practice for the stock of major corporations from industrial countries. In the United States, foreign equity may be issued and traded on an exchange by setting up American Depository Receipt programs (ADRs). ${ }^{103}$ The registration and

102 For further discussion, see Johnson, Fisher, Harris (1990).

${ }_{103}$ ADRs are U.S. dollar-denominated equity-based instruments issued in the United States. ADRs are backed by a trust containing stocks of non-U.S. companies and set up with a U.S. bank by an intermediary who buys those stocks in foreign markets. The price of ADR certificates and dividends received by investors depends on the performance of the underlying ordinary shares that are held by the bank as custodian. Owners of ADRs are always able to convert these claims into the underlying securities as desired. The creation of an ADR does not necessarily constitute a listing on a U.S. stock exchange but disclosure requirements that need to be satisfied for public issues in most established markets are typically onerous and may be prohibitively expensive for developing country issuers, although they may be reduced, for example, by marketing through private placements. In the past, this latter technique has reduced initial costs, but liquidity in the secondary market has been typically limited. Recent regulatory changes in the United States (Regulation $\mathrm{S}$ and Rule 144a of the Securities and Exchange Commission) have liberalized provisions in this area, although liquidity concerns remain for subinvestment grade paper. An alternative route is the packaging of a number of securities issued by developing country borrowers in an investment fund. Such funds may be attractive to investors because shares of the fund are traded on established exchanges and information costs are reduced, thus potentially offering a deeper market while pooling transaction costs.

\section{Facilitating Market Re-Entry}

In sum, developing country borrowers attempting to regain access to spontaneous private financing in international markets confront difficult obstacles. Negative market perceptions are not easy to remove in the face of, inter alia, concerns about interruptions and reversals in adjustment and structural reform efforts, poor debt-servicing records, the complexities in evaluating sovereign risk, and the absence of well-established and enforceable seniority arrangements to privilege new private flows. Nevertheless, as discussed, few highly indebted middle-income developing countries, particularly from Latin America, have in the past two years initiated a modest return to spontaneous market access, following a long period of exclusion. While limited in scope, their initial experiences point to a number of factors likely to characterize a more generalized process of market re-entry.

Sound macroeconomic policies accompanied by wide-ranging structural reforms are critical to regaining the confidence of creditors and investors. Where excessive debt burdens give rise to serious doubts that new flows could be credibly protected from contagion effects, a major reorganization of the old debt, including by means of debt and debtservice reduction, is often also required. Given such a context, the transition process may be facili-

\footnotetext{
represents a separate process that improves the marketability in the U.S. of equity securities issued abroad. In particular, ADRs may be traded directly among U.S. investors, with clearance and settlement handled by the custodian bank in the United States. Thus, potentially expensive and risky clearance and settlement on foreign markets are avoided.
} 
tated at the margin by a number of other factors, including the insulation of new flows, the establishment of differential debt payment policies, collateralization, and supportive guarantees or insurance from external agencies. Market re-entry may also be conditioned by measures to reduce transaction costs and liquidity risk. Private placement of securities issues and other vehicles may be helpful in this regard.

Recent experiences of re-entry to the international capital markets bring to light three further factors that can help make the transition successful. First, the developing country borrowers recently gaining access have for the most part been corporations, both from the public and private sectors, rather than central governments. Most sovereign borrowers of the re-entering developing countries were in the process of restructuring their debts, including through debt and debt-service reduction, and the time was thus not ripe for them to attempt tapping voluntary sources of funds on any significant scale. Re-entry for these sovereign borrowers must therefore wait until investors have had time to reassess new risk-return trade-offs and examine the improved reliability of price signals from deeper and more liquid secondary markets for their old debts. In contrast, re-entering developing country corporations have been helped by the increased availability of information that has allowed foreign investors to identify strong balance sheets and good business prospects. Second, international bond and equity markets have constituted important points of re-entry. Since the role of bank lending to developing countries in the foreseeable future is expected generally to be limited to project, trade, and interbank credits, and since large pools of investment funds worldwide are increasingly being channeled through securities markets, any significant resumption of market access for middle-income developing countries will probably focus on these latter markets. Finally, market participants report that flight capital has been an important source of demand for many of the international bond and equity issues of new developing country entrants. As a result of cultural, family, and business connections, developing country nationals or residents holding substantial assets abroad may be relatively better able to gauge the significance of policy changes in their countries and to assess the risks involved in holding claims on a given corporation. It is thus not surprising that pools of flight capital-which often became significant just before the loss of spontaneous market access by a number of heavily indebted middleincome developing countries-are now among the first sources to respond to attempts by developing country borrowers to tap international securities markets. This phenomenon again highlights the importance of sound policies that send clear and credible signals to those markets and help restore investor confidence. 


\section{Bank Debt Restructurings and Secondary Market Developments}

$\mathbf{P}$ revious reports in this series have documented the shift in financing arrangements for countries with debt-servicing difficulties that took place during the last few years. This involved a move away from more traditional financing packages-primarily involving reschedulings of principal and, in some cases, concerted new lending-and toward more innovative financing instruments (e.g., debt-equity conversions, cash buy-backs, collateralized debt exchanges, and securitization) aimed at reconciling the diverse interests of debtors and creditors within a market-based framework. This trend has been associated with the emergence of an active secondary market for claims on developing countries. During the period under review, continuing efforts to strengthen the debt strategy through debt and debt-service reduction operations supported by the Fund, the World Bank and other official creditors has built upon and reinforced such market-based techniques, in conjunction with more traditional options. This section discusses recent developments in these areas, covering recent bank debt restructurings, developments in debt conversion schemes, and in the secondary market for claims on developing countries.

\section{Bank Debt Restructurings}

There were relatively few rescheduling agreements in 1989, in part because of uncertainty over changes in the debt strategy, including the elaboration of new proposals for commercial debt and debtservice reduction with support from official creditors (Table 14). Moreover, for a prolonged period in 1989 , creditors and debtors preferred to await the conclusion of discussions between Mexico and its creditor banks. Smaller debtors, in particular, were generally unable to make progress in their negotiations with banks in view of the latter's hesitancy to agree to what could constitute precedent-setting terms. Preliminary agreement on the Mexican commercial bank package in July 1989, which incorporated innovative debt and debt-service reduction

Note: This section was prepared by John Clark, Juan Carlos Di Tata, Alessandro Leipold. elements, was followed by similar understandings for the Philippines and Costa Rica, in August 1989 and November 1989, respectively. In addition, Nigeria and Trinidad and Tobago completed bank rescheduling agreements in 1989, after having reached agreements in principle with bank creditors in 1988. In 1989, agreements in principle or tentative agreements with bank advisory committees on reschedulings were reached in the cases of Honduras, Jordan, Poland, and Zaire, the latter two cases representing deferments. The amount of medium- and long-term bank debt restructured in 1989 amounted to $\$ 51.5$ billion, of which over 90 percent was accounted for by the financing agreement between Mexico and its creditor banks (Table A30).

Several countries concluded financing packages with their commercial bank creditors in 1990 and early 1991. These included debt and debt-service reduction packages with Costa Rica, Mexico, Niger, Nigeria, the Philippines, Uruguay, and Venezuela (Tables 15 and A31). Other agreements included a rescheduling for Jamaica and Madagascar, a two-stage restructuring agreement with Morocco, a rescheduling agreement that included waivers for debt-reduction operations with Senegal, amendments to previous rescheduling terms for Chile (with agreement also on new commercial bank loans), and an agreement with Colombia to refinance bank debt amortization payments falling due during 1991-94. (These agreements are discussed in detail below and terms are listed in Tables A32-A34.) The total of medium- and longterm bank debt restructured during 1990 amounted to $\$ 26.7$ billion. In addition to the above agreements, in September and November 1990, Argentina obtained specific waivers from commercial bank creditors to permit purchasers of the telephone company (ENTEL) and of the national airline (Aerolineas Argentinas) to tender certificates of foreign debt for part of the purchase price. Early in 1991 a number of other countries were at various stages in discussing a restructuring of their debt to commercial banks, including Argentina, Bolivia, Brazil, Bulgaria, Cameroon, Congo, Côte d'Ivoire, Ecuador, Gabon, Guyana, Honduras, Jordan, Mozambique, Paraguay, Poland, and Togo. In most of these cases, debtors have requested that restruc- 


\section{Table 14. Chronology of Bank Debt Restructurings and Bank Financial Packages, 1984-March 1991}

\begin{tabular}{|c|c|c|c|c|c|c|c|}
\hline \multicolumn{8}{|c|}{ Agreement classified by month of signature' } \\
\hline \multicolumn{4}{|l|}{1984} & \multicolumn{4}{|c|}{ Jamaica: May } \\
\hline \multirow{2}{*}{\multicolumn{4}{|c|}{$\begin{array}{l}\text { Brazil: January } 2 \\
\text { Chile: January, June, and November }\end{array}$}} & \multicolumn{4}{|c|}{ Mozambique: May $^{3}$} \\
\hline & & & & \multicolumn{4}{|c|}{ Zaïre: May (deferment) } \\
\hline \multicolumn{4}{|c|}{ Sierra Leone: January } & \multicolumn{4}{|c|}{ Chile: June } \\
\hline \multicolumn{4}{|c|}{ Guyana: January, July (deferment) } & \multicolumn{4}{|c|}{ Honduras: June ${ }^{3}$} \\
\hline \multicolumn{4}{|c|}{ Nicaragua: February (deferment) } & \multicolumn{4}{|c|}{ Madagascar: June (modification of 1985 agreement) } \\
\hline \multicolumn{4}{|c|}{ Peru: February ${ }^{3}$} & \multirow{2}{*}{\multicolumn{4}{|c|}{$\begin{array}{l}\text { Argentina: } \text { August }^{2} \\
\text { Morocco: September }\end{array}$}} \\
\hline \multicolumn{4}{|c|}{ Senegal: February } & & \\
\hline \multicolumn{4}{|c|}{ Niger: March } & hania: Sept & ber (modific & n of 1986 agree & nt) \\
\hline \multicolumn{4}{|c|}{ Mexico: April (new financing only) } & via: Nove & (amendme & o 1981 agreeme & \\
\hline Sudan: April ( & dification of & 81 agreement & & ador: Nov & er (modific: & of 1985 agreet & $t)^{2.3}$ \\
\hline Yugoslavia: M & & & & eria: Nove & $\mathrm{e}^{2.3}$ & & \\
\hline Jamaica: June & & & & ezuela: Nc & nber & & \\
\hline Zaïre: June (de & ment) & & & on: Decen & & & \\
\hline Poland: July ${ }^{2}$ & & & & ippines: D & mber & & \\
\hline Madagascar: $\mathrm{C}$ & ber & & & & & & \\
\hline Liberia: Decer & & & & bia, The: & ruary & & \\
\hline Zambia: Dece & & & & e: August & endment to & 37 agreement $)^{3}$ & \\
\hline 1985 & & & & guay: Mar & modificatio & 1986 agreemen & \\
\hline Côte d'Ivoire: & $\mathrm{rch}^{2}$ & & & d'Ivoire: & $\mathrm{ril}^{2,3}$ & & \\
\hline Mexico: Marc & August & & & nea: April & & & \\
\hline Costa Rica: M & & & & o: May & & & \\
\hline Senegal: May & & & & ind: July & & & \\
\hline Philippines: M & & & & oslavia: S & mber ${ }^{2}$ & & \\
\hline Zaïre: May (do & ment) & & & awi: Octob & & & \\
\hline Guyana: July & erment) & & & il: Novem & & & \\
\hline Argentina: Au & & & & & & & \\
\hline Jamaica: Septe & & & & eria: April & & & \\
\hline Panama: Octo & & & & e: June (D & rment) & & \\
\hline Sudan: Octobe & nodification & 1981 agreem & & and: June ( & erment) ${ }^{3}$ & & \\
\hline Chile: Novemt & & & & duras: Aus & & & \\
\hline Colombia: Dec & ber $r^{4}$ & & & an: Septen & $r^{2,3}$ & & \\
\hline Ecuador: Dece & $e r^{2}$ & & & er: Octobe & & & \\
\hline Madagascar: D & ember (mod & ation of 1984 & treement) & and: Octob & Deferment) & & \\
\hline Yugoslavia: D & mber & & & idad and $T$ & go: Decemt & & \\
\hline 1986 & & & & & & & \\
\hline Dominican $\mathrm{Re}$ & lic: Februa & & & ippines: F & tary & & \\
\hline Morocco: Feb & & & & ico: Febru & & & \\
\hline Venezuela: Fe & ary & & & lagascar: $A$ & & & \\
\hline South Africa: & reh (standst & & & garia: Apri & tandstill) ${ }^{3}$ & & \\
\hline Niger: April & ment) & & & ta Rica: M & & & \\
\hline $\begin{array}{l}\text { Zaïre: May (de } \\
\text { Brazil: July }\end{array}$ & ment) & & & $\begin{array}{l}\text { aica: June } \\
\text { occo: Sept }\end{array}$ & ber & & \\
\hline Uruguay: July & & & & egal: Septe & & & \\
\hline Poland: Septer & & & & ombia: De & ber $r^{4}$ & & \\
\hline Romania: Sept & ber & & & e: Decemt & (amendmen & previous agree & nts) \\
\hline Congo: Octobs & & & & ezuela: De & nber & & \\
\hline Côte d'Ivoire: & cember & & & & & & \\
\hline 1987 & & & & er: January & & & \\
\hline South Africa: & rch & & & guay: Janu & & & \\
\hline Mexico: Marc & ublic secto & $b t)^{2}$ & & eria: Marcl & & & \\
\hline & & & Underneg & ation & & & \\
\hline Argentina & Brazil & Cameroon & Côte d'Ivoire & Gabon & Honduras & Mozambique & Poland \\
\hline Bolivia & Bulgaria & Congo & Ecuador & Guyana & Jordan & Paraguay & Togo \\
\hline $\begin{array}{l}\text { Sources: Rest } \\
\text { Note: "Restru } \\
\text { 'Agreemente } \\
2 \text { The restruct } \\
\text { 3 Agreed in pr } \\
\text { 4 Refinancing } \\
\text { 5 A separate C }\end{array}$ & $\begin{array}{l}\text { uring agreem } \\
\text { ring" covers } \\
\text { e signed or r } \\
\text { g agreement } \\
\text { iple or tentati } \\
\text { eement. } \\
\text { deal for new }\end{array}$ & $\begin{array}{l}\text { heduling and a } \\
\text { ed in principle } \\
\text { udes new finan } \\
\text { greement with } \\
\text { neing was arrar }\end{array}$ & $\begin{array}{l}\text { certain refinanci } \\
\text { signature has not } \\
\text { g. } \\
\text { nks' Steering Con } \\
\text { d at the same tim }\end{array}$ & $\begin{array}{l}\text { f member } \\
\text { taken place) } \\
\text { tees. }\end{array}$ & $\begin{array}{l}\text { tries. } \\
\text { t all signed }\end{array}$ & ents have bec & ffective. \\
\hline
\end{tabular}


Table 15. Impact of Debt and Debt-Service Reduction Packages

(in billions of U.S. dollars)

\begin{tabular}{|c|c|c|c|c|c|c|c|c|c|c|}
\hline & \multirow{2}{*}{$\begin{array}{c}\text { Public } \\
\text { Sector } \\
\text { Bank Debt } \\
\text { Before } \\
\text { Debt } \\
\text { Operations }\end{array}$} & \multirow{2}{*}{$\begin{array}{l}\text { Eligible } \\
\text { Bank Debt } \\
\text { Before } \\
\text { Debt } \\
\text { Operations }\end{array}$} & \multirow{2}{*}{$\begin{array}{c}\text { Eligible } \\
\text { Bank Debt } \\
\text { Extin- } \\
\text { guished by } \\
\text { Principal } \\
\text { Reduction } \\
\text { Operations }\end{array}$} & \multicolumn{2}{|c|}{$\begin{array}{c}\text { Debt Subject to } \\
\text { Lower Interest } \\
\text { Rates }\end{array}$} & \multirow{2}{*}{$\begin{array}{c}\text { Effective } \\
\text { Reduction } \\
\text { in Gross } \\
\text { Bank } \\
\text { Debt }\end{array}$} & \multirow{2}{*}{$\begin{array}{c}\text { Debt } \\
\text { Incurred } \\
\text { for } \\
\text { Enhance- } \\
\text { ments }\end{array}$} & \multirow{2}{*}{$\begin{array}{c}\text { Use of } \\
\text { Own } \\
\text { Reserves } \\
\text { for } \\
\text { Enhance- } \\
\text { ments }\end{array}$} & \multirow{2}{*}{$\begin{array}{c}\text { Net } \\
\text { Effective } \\
\text { Reduction } \\
\text { in Total } \\
\text { Debt' }\end{array}$} & \multirow[b]{2}{*}{$\begin{array}{l}\text { New } \\
\text { Money }\end{array}$} \\
\hline & & & & $\begin{array}{l}\text { Face } \\
\text { Value }\end{array}$ & $\begin{array}{l}\text { Debt } \\
\text { reduction } \\
\text { equivalent }\end{array}$ & & & & & \\
\hline $\begin{array}{l}\text { Costa } \\
\text { Rica }\end{array}$ & 1.7 & 1.6 & 0.8 & 0.6 & 0.2 & 1.0 & 0.2 & 0.04 & 0.8 & - \\
\hline Mexico & 66.2 & 48.5 & 7.1 & 22.5 & 7.9 & 15.0 & 5.7 & 1.4 & 7.9 & 1.1 \\
\hline Niger & 0.1 & 0.1 & 0.1 & - & - & 0.1 & - & $0.02^{2}$ & 0.1 & - \\
\hline Philippines & 12.8 & 7.0 & 1.3 & - & - & 1.3 & 0.3 & $0.4^{3}$ & 0.6 & 0.7 \\
\hline Uruguay & 1.6 & 1.6 & 0.6 & 0.5 & 0.1 & 0.8 & 0.2 & 0.25 & 0.3 & 0.1 \\
\hline Venezuela & 20.2 & 19.8 & 2.0 & 10.5 & 2.6 & 4.6 & 1.2 & 1.4 & 2.0 & 1.2 \\
\hline
\end{tabular}

turing options include debt and debt-service reduction instruments.

\section{Recent Financing Packages}

Mexico formally initiated negotiations on a multiyear bank financing package in April 1989; preliminary agreement was reached with the bank advisory committee in July 1989 and the term sheet was issued in September. ${ }^{104}$ The package was completed in February 1990 and participating banks allocated 9.2 percent of claims to the new money option, 42.9 percent to the discount bond exchange, and 47.9 percent to the par bond exchange. As a result, bank debt amounting to $\$ 7$ billion was extinguished outright, while claims of $\$ 23$ billion were subject to a below market rate of interest of 6.25 percent. This implied a total reduction in the present value of bank claims on Mexico of about $\$ 15$ billion (about 30 percent of bank debt and 15 percent of total debt). In cash flow terms, the agreement provided for annual debt-service savings equivalent to 0.5 percent of GDP, backdated to July 1, 1989. New money commitments for the period ending in 1992 amounted to $\$ 1.1$ billion. The cost of the principal and interest guarantees on the new bonds amounted

104 For details on the terms of the agreements with Mexico, the Philippines, and Costa Rica, see International Monetary Fund, International Capital Markets (1990), pp. 32-33. to $\$ 7$ billion, which was covered by financing received from the World Bank, the International Monetary Fund, and bilateral sources, as well as own reserves.

The Philippines' bank financing package was agreed in outline in August 1989, and the term sheet was circulated in October 1989. Banks were invited to participate by providing new money in securitized form or to exit through a cash buy-back at a market-related price. The package also provided for waivers to allow for second round debt and debtservice reduction operations, a rescheduling of previous new money disbursements, and a statement of intent by the Philippine authorities to revive the debt-equity conversion scheme. In January 1990, the Philippines completed a buy-back of $\$ 1.3$ billion of claims (about 20 percent of the eligible stock of bank debt and 5 percent of total debt) at a price of 50 cents per dollar of face value, close to the prevailing secondary market price. This was financed through resources obtained from the World Bank, the International Monetary Fund, and bilateral sources, and from own reserves. The operation provided for a net reduction of external interest payments of about $\$ 80$ million a year over 1990-92, equivalent to about 0.2 percent of GDP. The other components of the package were signed in February 1990 , including new money of $\$ 715$ million and the rescheduling of about $\$ 200$ million a year of principal falling due. Discussions on a financing package 
for 1991-92, which could include debt and debtservice reduction operations, are continuing.

In November 1989, after a lengthy period of negotiation, Costa Rica reached agreement in principle with its bank advisory committee on a package including debt and debt-service reduction and the regularization of arrears, without a new money component. The package was signed in May 1990. In contrast to the cases of Mexico and the Philippines, Costa Rica had made only partial interest payments to banks during the period of negotiation. Banks allocated 62 percent of claims to a buy-back option, while remaining debt was divided evenly between two bond exchanges. As a result, claims of about $\$ 1$ billion were eliminated outright through the buy-back and cash downpayment on past due interest, while the reduction in interest rates on the bonds was equivalent to additional debt reduction of about $\$ 160$ million. This implied a total reduction in the present value of bank claims of about 70 percent. These operations required funding of $\$ 226$ million, which was obtained from bilateral official sources and own reserves.

On June 25, 1990, Venezuela reached agreement with its bank advisory committee on a term sheet including a menu of five options. Four of the five options involve debt or debt-service reduction by means of exchanging eligible debt: (i) through a "buy-back" involving three-month, fully collateralized notes with present value equal to 45 percent of the eligible debt; (ii) at a ratio of 1:0.7 for new bonds with a fully collateralized 30 -year bullet maturity, and with a 14-month rolling interest guarantee for the life of the bonds; (iii) at par for new bonds carrying a below market, fixed interest rate of 6.75 percent, with a 30 -year bullet maturity, full principal guarantee, and 14-month interest collateral; and (iv) at par for new bonds carrying a temporary, front-loaded reduction in the interest rate, 17-year maturity (including 7 years' grace), and a 12-month rolling interest guarantee for the first five years. The fifth option involves new money in the form of a 20 percent increase in exposure via the purchase of new money bonds (15-year maturity, including 5 years' grace), which entitle banks to exchange simultaneously at par eligible debt for noncollateralized "debt conversion bonds" (17year maturity, including 7 years' grace) in an amount equal to five times their new money commitment; a portion of the new money bonds entail rights to conversion into equity at par. At least 40 percent of the new money bonds are to be issued by the Central Bank of Venezuela at LIBOR plus $7 / 8$ of 1 percent; the remaining new money bonds would be issued by the Government at LIBOR plus 1 percent. Par and discount bonds feature a value recovery mechanism that takes the form of fully detachable and negotiable oil warrants that give the holder the right to receive increased payments in the event that Venezuela's oil export price exceeds \$26 a barrel on April 15, 1996, or the same price adjusted for inflation thereafter. The agreement elicited virtually 100 percent participation from creditor banks, whose choices resulted in the following allocation of eligible bank exposure ( $\$ 19.8$ billion): 38 percent to the reduced interest par bonds; 31 percent to the new money bonds; 15 percent to the frontloaded interest reduction par bonds; 9 percent to the floating rate discount bonds; and 7 percent to the buy-back option. The buy-back operation (through the exchange of eligible debt for fully collateralized, three-month notes) was implemented on October 18, and final signing took place on December 5,1990 . The package provides an average of about $\$ 380$ million in net interest savings a year over the period 1991-95, and $\$ 1,212$ million of new money. The cost of financing the package was $\$ 2.6$ billion.

The authorities of Chile and the bank advisory committee completed a term sheet on October 5, 1990 that amended previous rescheduling agreements. Although pricing arrangements remained unchanged, the amendment extended the amortization schedules for previously restructured debt and for the 1983-85 new money loans, and also provided for an extension of the retiming periods during which annual interest periods will be maintained, for more flexible provisions enabling Chile to engage in market-based buy-backs and debt exchanges over the next three years, for modifications to allow any amendment or waiver currently requiring approval by 100 percent of the banks instead to require approval by banks having at least 95 percent of the unpaid principal amount under each agreement, and, finally, for an extension of the existing short-term trade-related debt facility through December 31, 1991. The agreement was finalized on December 12, 1990 and covers total maturities of $\$ 1.8$ billion. In addition, the authorities successfully placed, with a group of twenty banks, $\$ 320$ million in bonds that was not tied pro rata to existing banks' exposure.

On November 5, 1990, the authorities of Uruguay and the bank advisory committee agreed on a term sheet for a financing package that includes three main options: a buy-back, a par bond exchange, and new money. Total eligible debt amounts to $\$ 1,604$ million, or 100 percent of medium- and long-term maturities. The buy-back price was set by Uruguay at 56 cents per dollar of face value. Debt exchanged at par for new bonds carries a fixed interest rate of 6.75 percent, with a fully collateralized 30-year bullet maturity and an 18-month rolling interest guarantee for the life of the bond. The new money option involves a 20 percent increase in exposure via the purchase of new 
bonds (15-year maturity, including 7 years' grace, at LIBOR plus 1 percent), which would entitle banks to exchange simultaneously at par eligible debt amounting to up to five times the amount of new money for noncollateralized "debt conversion notes." Purchasers of fixed rate notes will be entitled to a value recovery clause allowing for larger payments in the event of the favorable performance of an index of Uruguay's terms of trade, to be calculated on the basis of developments in the export prices of beef, rice, and wool and the import price of oil. Banks which committed to the deal by December 7, 1990 received an early participation fee of $1 / 8$ of 1 percent of their Uruguayan exposure. Available information on the choices submitted by banks indicate the following allocation of exposure: 39 percent to buy-back, 33 percent to the par exchange, and 28 percent to the new money option. The agreement was finalized on January 31, 1991 and the exchanges took place on February 19, 1991. The cost of financing the package is estimated at $\$ 461$ million. In addition to providing $\$ 89$ million of new money, implementation of the package is expected to lead to a net reduction of interest payments of about $\$ 30$ million a year over 1991-95, equivalent to about 0.3 percent of GDP or 1.3 percent of exports of goods and nonfactor services.

On December 1, 1990, Colombia and the steering committee of its commercial bank creditors reached agreement in principle on a new refinancing package. The preliminary agreement consists of a syndicated loan for $\$ 1,775$ million to refinance about 93 percent of principal payments falling due to banks during 1991-94. The package would include two facilities: a basic loan and two series of floating rate notes. The basic loan ("integrated loan facility"), which would amount to $\$ 1,575$ million, would have a $12^{1 / 2}$-year maturity and a spread of 1 percentage point over the 6-month LIBOR. Disbursements would take place semi-annually and would be frontloaded to correspond to the present amortization schedule. In addition, there is an early participation fee of $1 / 2$ of 1 percentage point. The floating rate notes would bear an interest rate of $1 \frac{1}{2}$ percent over the 6-month LIBOR, with a 5-year repayment period and 2 years' grace. The first series, amounting to $\$ 100$ million, would be issued in 1991-92, while the second series, for a similar amount, would be issued in 1993-94. By the early participation deadline of January 17, 1991, 95 banks had confirmed their participation, accounting for 97 percent of the total package.

After reaching an agreement in principle in October 1989, Madagascar and its bank creditors signed a final agreement in April 1990. Under the agreement all principal falling due on December 15, 1989, and half the principal falling due in 1990-93 (totaling about $\$ 21$ million) have been rescheduled with a 9-year maturity period, including $31 / 2$ years' grace. The agreement also allows for debt buybacks, subject to the restriction that buy-backs of more than \$5 million a year of debt (face value) must be undertaken with concessional funds provided specifically for that purpose. Two months later, in June 1990, a rescheduling agreement was signed between Jamaica and its bank creditors. It covers some $\$ 330$ million of claims, which are rescheduled for periods up to $14 \frac{1}{2}$ years, and provides for a reduction in the spread from $1 \frac{1 / 4}{4}$ percent over LIBOR to $13 / 16$ of 1 percent, while allowing for buy-backs of up to $\$ 35$ million annually. On September 28, 1990, Senegal and its commercial bank creditors concluded an agreement to reschedule maturities for an amount of $\$ 37$ million, comprising most of the country's commercial bank debt and to provide flexibility for future buy-back operations and debt-equity conversions.

On January 14, 1991, Niger and its commercial bank creditors reached a preliminary agreement on a debt and debt-service reduction package, which would be the first to involve official funding from the Debt Reduction Facility of the International Development Agency (IDA). The agreed package covers approximately $\$ 110$ million of bank debt under two options, the first involving the exchange of claims for 60-day notes with a face value equivalent to 18 percent of the outstanding principal amount of the debt, the second involving the exchange of claims at par for 21-year, non-interestbearing notes. The principal on these notes is to be guaranteed by zero-coupon bonds purchased by the Banque Centrale des Etats de l'Afrique de l'Ouest (BCEAO), with their net present value estimated at around 18 cents to the dollar. The operation has been structured to involve a novation, that is, the substitution of a new contract, debt or obligation for an existing one, between the same or different parties, in order to avoid the invocation of sharing clauses by nonaccepting banks. The package is to be financed by grants from the IDA facility, France, and Switzerland. To simplify processing the offer, the two options will be mutually exclusive; that is, banks will not be able to split their claims between the short- and long-term note exchange.

Finally, on March 2, 1991, Nigeria and the steering committee of its commercial bank creditors agreed in principle on a financing package including three options: a buy-back, a par exchange for registered bonds, and new money. Total eligible debt amounts to $\$ 5.8$ billion. Debt exchanged at par for the new registered bonds would carry a fixed interest rate of 6.25 percent with a fully collateralized 30 -year bullet maturity and a 12-month interest guarantee. The new money option involves the exchange of existing debt for registered bonds and the provision by banks of new loans equivalent to 
Table 16. Debt Conversions, 1985-901

(In millions of U.S. dollars)

\begin{tabular}{|c|c|c|c|c|c|c|}
\hline & 1985 & 1986 & 1987 & 1988 & 1989 & 1990 \\
\hline Argentina & 469 & - & - & 764 & 1,180 & 6,670 \\
\hline Brazil & 537 & 176 & 336 & 2,095 & 942 & $292^{2}$ \\
\hline Chile & 323 & 974 & 1,997 & 2.927 & 2,767 & 1,100 \\
\hline Costa Rica & - & 7 & 89 & 44 & 124 & 17 \\
\hline Ecuador & - & - & 127 & 261 & 31 & 58 \\
\hline Honduras & - & - & 9 & 14 & 47 & 32 \\
\hline Jamaica & - & - & 4 & 5 & 16 & $9^{3}$ \\
\hline Mexico & - & 413 & 1,680 & $1,056^{4}$ & 532 & 652 \\
\hline Nigeria & - & - & - & 70 & 304 & $157^{3}$ \\
\hline Philippines & - & 81 & 451 & 931 & 630 & 630 \\
\hline Uruguay & - & - & - & 104 & 53 & - \\
\hline Venezuela & - & - & 45 & 49 & 544 & 716 \\
\hline Total & 1,329 & 1,651 & 4,738 & 8,320 & 7,170 & $10,333^{5}$ \\
\hline \multicolumn{7}{|c|}{$\begin{array}{l}\text { Sources: Central Bank of Argentina; Central Bank of Brazil; Central Bank of Chile; Mexico. Ministry of Finance; Central Bank of } \\
\text { Philippines; Bank of Jamaica; Central Bank of Venezuela; and Fund staff estimates. } \\
\text { 'Face value of debt converted under official ongoing schemes. Figures do not inelude large-scale one-off cash buy-backs and debt exchanges. } \\
\text { 'As of June 30, 1990. } \\
\text { 'As of September 30. } 1990 \text {. } \\
\text { 'Does not include an estimated \$6-8 billion related to prepayment at a discount of private sector debt since August } 1987 \text { signing of an } \\
\text { agreement to restructure FICORCA debt. } \\
\text { SIncludes partial data for some countries. }\end{array}$} \\
\hline
\end{tabular}

10 percent of the amount of exchanged debt. The agreement also provides for the payment of some $\$ 300$ million in arrears accumulated since March 1990.

\section{Debt Conversion Programs}

The amount of debt extinguished through official ongoing debt conversion programs rose to an estimated $\$ 10.3$ billion in 1990 (Table 16), largely reflecting the privatization of two state-owned enterprises in Argentina. The $\$ 3.1$ billion increase compared with 1989 brought the total volume of debt conversions past the previous peak of $\$ 8.3$ billion reached in 1988. In a number of countries, the pace of debt conversions had slowed in recent years as conversion programs were curtailed in the face of concerns about the domestic liquidity implications of such operations, the additionality of associated investment, and pricing (Table A35). Conversion activity has revived recently, however, and may be expected to continue to be strong for several countries in the period ahead, reflecting new commitments under bank financing packages and accelerated efforts to attract foreign investment.

The Government of Argentina has sharply stepped up the pace of debt-equity conversions as it seeks to privatize and recapitalize the country's state-owned enterprises. Initial efforts focused on the sale of the telephone company, ENTEL, and the state airline, Aerolineas Argentinas, the fourth and fifth largest state-owned enterprises. ENTEL, which was auctioned as two separate entities (TELNOR to operate in the northern part of the country and TELSUR to operate in the south), was sold to two consortiums for a total of \$214 million in cash and $\$ 5.03$ billion in Argentine foreign debt certificates. In addition, the purchasers committed some $\$ 5$ billion in capital improvements over the next ten years. Aerolineas Argentinas was sold for $\$ 260$ million in capital, half up-front and the remainder over five years, $\$ 2$ billion in debt and a commitment to 
$\$ 700$ million in capital improvements over a sevenyear period. In both cases, finalization of the sale was dependent on obtaining necessary waivers from commercial banks. In the case of the TELNOR purchase, delays in assembling commited debt instruments resulted in the original consortium losing its acquisition rights. The rights were awarded to a third consortium on the same terms as the previously accepted offer. The privatization effort was expanded in October 1990 with the passage of a decree establishing a framework for the sale of a number of other companies, as well as for granting concessions in the operation of the national electricity and gas companies. In response to these initiatives, the formation of the Argentine Private Development Trust was announced in April 1990. The fund manages $\$ 1.2$ billion in Argentine debt claims, which are to be converted into shares of privatized Argentine companies. Participating banks, which include Argentine, Asian, European, and U.S. banks, subscribe to the fund by contributing Argentine claims.

Mexico, which suspended its debt-equity conversion program in 1987, announced regulations for a new debt-equity system in March 1990 . Under the 1990 financing package with commercial banks, the Mexican authorities committed to introduce a new program that would allow for the conversion of $\$ 3.5$ billion of existing bank claims (original face value). Auctions were held in July and October 1990. In the first auction, 27 of 359 offers were accepted for $\$ 1$ billion of claims. The lowest successful bid, which determined the auction price for all successful bidders, was for a discount of 52 percent. In the second auction the authorities exercised their right to increase the offered amount of conversion rights beyond the initially-specified $\$ 1.5$ billion in view of the attractiveness of the offers. As a result, an additional $\$ 1$ billion of debt was accepted, bringing the total in the two exchanges to $\$ 3.5$ billion and establishing a discount of 52 percent. The book value of the reduction in the debt stock would be $\$ 2.6$ billion against which $\$ 1.7$ billion of swap rights would be issued. Successful bidders were required to deposit claims equivalent to 5 percent of the rights acquired, with the remainder to be paid within 18 months. Under the regulations, eligible investments are to be limited to approved infrastructure projects and up to 50 percent of the cost of privatization purchases.

In 1989, Venezuela introduced a number of changes to its debt-equity program, including establishment of an auction-based mechanism to replace the administered pricing and allocation mechanisms of the previous program. Auctions were initially held on a monthly basis with an annual ceiling on conversions. Successful bidders, having placed a 5 percent deposit at the outset of the process, received a nontransferable, nonnegotiable right, valid for 60 days, to effect a conversion of the tendered bid at the bid discount. In the second half of 1990, the authorities progressively moved to emphasize debtequity conversions involving large investment projects in selected sectors (particularly petrochemicals and aluminum) at administratively determined discounts. In November and December 1990, a series of decrees were issued establishing norms applicable to large projects. ${ }^{105}$ Following completion of the bank-debt restructuring agreement at the end of 1990 , the pace of debt conversions, which had fallen off sharply, was expected to pick up once again. As of February 1991, the authorities had already approved nine investment projects in the petrochemical sector, involving a total investment of $\$ 2.6$ billion, of which $\$ 0.6$ billion was to be financed through debt-equity swaps. Under the terms of the restructuring agreement, Venezuela is committed to maintaining a program of debt conversions of at least $\$ 600$ million (discounted value) a year during 1991-93.

The debt converted by the Philippines in 1990 was largely associated with privatization operations under debt-for-asset schemes. In line with announcements made at the time of the 1989 bank debt restructuring agreement, the authorities introduced a new auction-based system for debt-equity conversions in December 1990. The new program specified that conversion rights for central bank debt with a face value of $\$ 300$ million a year would be auctioned on a quarterly basis over a three-year period. The number of sectors eligible for investment under the scheme was reduced from nine to four: bank privatizations and export, energy, or agricultural ventures. The Philippines held its first auction of conversion rights under the new system on February 20,1991; it was fully subscribed and discounts ranged from 50 percent to 55 percent.

The pace of conversions for Chile, accounting for the largest portion of commercial bank debt extinguished through official ongoing debt conversion operations, fell off sharply in 1990 as discounts became more limited and eligible debt stocks declined. Conversions under Chapter 18 of the country's foreign exchange regulations, which the authorities began to limit during 1989 in response to concerns about domestic liquidity, recovered to around $\$ 0.6$ billion in 1990 , after having fallen by

\footnotetext{
105 Under the 1990 agreement, 50 percent of certain specified new money bonds may be converted into equity at par. Thus, up to $\$ 364$ million of the $\$ 1.2$ billion in new money commitments are eligible for debt conversion at par. The decrees also establish that a 15 percent minimum discount applicable to most larger projects would not be binding in the case of infrastructure projects, where it could be less and is left to the discretion of the President.
} 
$\$ 0.5$ billion to $\$ 0.4$ billion in $1989 .{ }^{106} \mathrm{~A}$ substantial decline was observed in foreign investment related conversions under Chapter 19, down to $\$ 0.4$ billion from $\$ 1.9$ billion in 1989 .

The bank restructuring agreements for a number of other countries also contained commitments to engage in debt-equity swaps. In Costa Rica, the Government committed to retire up to $\$ 20$ million of debt a year over a five-year period. Uruguay committed to converting 30 percent of the new money bonds issued under its 1991 restructuring agreement into equity at par over the next three years. In late 1989, Nigeria expanded its debt conversion scheme to include restructured bank debt, in addition to restructured debt, in the form of promissory notes, owed to foreign suppliers; the scheme was suspended in October 1990, but reactivated in January 1991.

The resurgence of such debt-equity programs has been accompanied by increased interest in other forms of conversions, particularly debt-for-nature and debt-for-development swaps. These operations have tended to take the form of acquisition of debt, through purchases by charitable organizations at a discount on the secondary market, which are then converted into local currency instruments, often at par and generally at a discount less steep than that prevailing in the secondary market. In some instances, banks have donated debt to charitable groups. Such operations effectively involve two expenditure components for the host country's public sector: a buy-back of debt intermediated by the charitable organization; and a contribution to a given project's financing, which is commensurate with the differential between the discounts obtained by the charitable organization in the secondary market and that applied when the debt is converted into local currency. In addition, the project may entail future recurrent expenditures for the host country's public sector. As detailed in previous reports in this series, such programs were established in Bolivia, Costa Rica, Ecuador, and the Philippines in 1987-89. A number of other countries have subsequently established similar programs. Several programs were launched or expanded during 1990. The Dominican Republic initiated a four-year program

106 Chile's debt conversion programs were introduced in 1985 and have undergone minor modifications since then. Official debt-equity conversions with remittance rights are covered by Chapter 19, which enables investors to convert debt into domestic currency to finance equity purchases. Other conversions without remittance rights are carried out under Chapter 18, which allows exchanges on the basis of repatriation of foreign assets of Chilean residents and the foreign exchange acquired on the parallel market. By collecting a fee related to the size of the discount on external debt and the spread between the parallel and official exchange markets, the authorities have been able to effectively retire public debt at a discount. to convert up to $\$ 80$ million into nature conservation funds in March 1990. In Argentina, a program was introduced under which up to $\$ 60$ million in debt could be exchanged to finance local environmental groups. Ecuador set the maximum amount of debt conversions under similar schemes to $\$ 150$ million, and the coverage of the program was widened to allow for local currency proceeds also to be used for agriculture and other social projects. Similar programs are underway or under consideration in a widening range of countries.

\section{Developments in the Secondary Market for Claims on Developing Countries}

The increased use of market-based debtreciuction operations has been facilitated by, and in turn contributed to, a marked growth in the importance of the secondary market for private claims on developing countries. In the period under review, available indicators suggest that the nominal value of debt traded in this market continued to grow, contributing to a narrowing of bid-offer spreads. After rising by around $\$ 20$ billion to a level of around $\$ 60$ billion in 1989 , the volume of nominal claims exchanged on the secondary market is estimated to have reached around $\$ 70$ billion in 1990 . Most trading involved claims on larger debtors. In particular, the trading volume for claims on Mexico is reported to have risen substantially following the completion of its debt-restructuring agreement in early 1990 .

The increasing volume of transactions has reportedly been accompanied by changes in the composition and financial strategies of market participants. Banks seeking to restructure their portfolios and investors acquiring debt claims for exchange under debt-equity conversion schemes continue to account for much of the market's volume. Increasingly, however, nonbank institutional investors attracted by perceived high yields are purch $\_$sing claims for their own portfolios (Chart 14). ${ }^{107}$ Nonbank participants have reportedly shown more interest in securitized as opposed to syndicated debt. The restructuring of Mexico's sovereign debt into collateralbacked par and discount bonds is viewed as having contributed to a significant increase in interest by

107 While the difference between yields on corporate "junk bonds" and U.S. Treasury borrowings (the yield spread) has nearly doubled since early 1989 , reflecting, inter alia, reduced liquidity in the junk bond market following the bankruptcy of the market's principal dealer (Drexel Burnham Lambert) and the closure of many savings and loans that had been active in the market, yields on developing country claims have on average declined somewhat over the period. 
Chart 14. Yield on Selected Debt

Instruments, 1987-First Quarter 1991

(In percent a year)

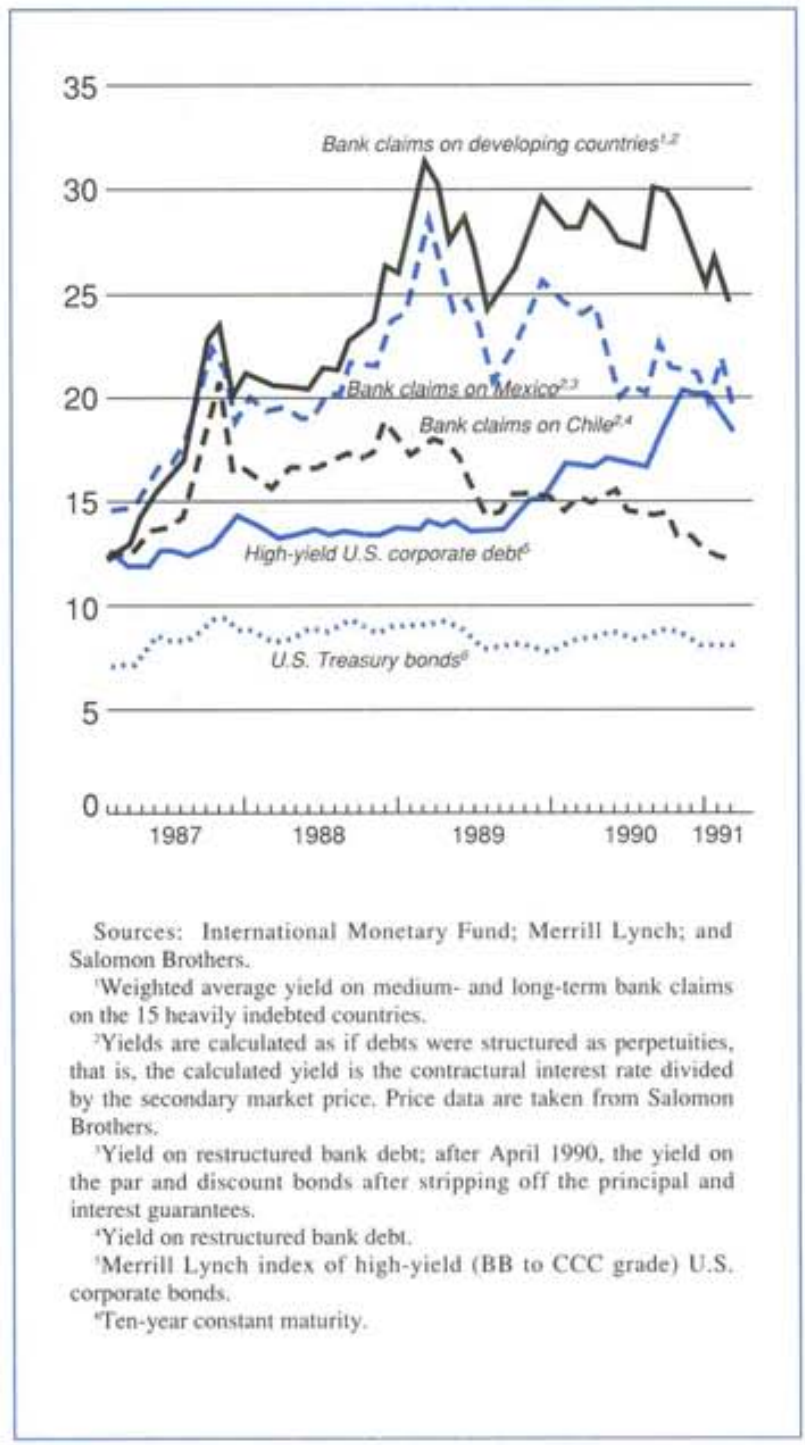

nonbanks in developing country bond issues in general. While familiarity and proximity to the United States have been cited as special factors encouraging interest by nonbank investors in claims on Mexico, nonbank holdings of claims on Venezuela are also expected to increase following completion of its restructuring agreement in December 1990. Some of this demand is expected to derive directly or indirectly from Venezuelan insurance companies, which have been permitted to hold several of the newly issued debt instruments as part of their required reserves.
The secondary market for developing country debt is centered mainly in New York and London and almost all of secondary market transactions are handled by about a dozen institutions; the four largest reportedly account for over 40 percent of the volume. Many of the trading firms are associated with U.S. money center banks that had large exposures to developing countries at the start of the debt crisis, although securities firms, and in one case a medium-sized European bank not heavily committed to developing country lending in 1982, also play important roles, especially in marketing claims to nonbank investors. Traders generally deal in both bonds and syndicated loans, and it is estimated that they currently hold between $\$ 250$ million to $\$ 1$ billion in claims on their books at any given time. In December 1990, the formation of the LDC Debt Traders Association Inc. was announced. The association seeks to improve the efficiency of the secondary market through adoption of standard documentation procedures.

Recent bank debt-restructuring exercises with a number of countries have contributed to a growing diversity of instruments now trading in the secondary market. ${ }^{108}$ Yields in the secondary market vary significantly between various types of claims on the same country, reflecting perceptions of payments priorities on different types of debt. Furthermore, in contrast to the conventional expectation that sovereign debt is less risky than corporate debt, and notwithstanding their partial collateralization, the Mexican par and discount bonds trade with higher yields than those currently observed for recent, shorter-maturity bond issues by Mexican corporations. On December 18, 1990, Moody's Investors Service set the sovereign ceiling rating for Mexico at $\mathrm{Ba} 2$ while giving the par and discount bonds ratings of $\mathrm{Ba} 3$. Explaining the lower rating attached to the debt-reduction bonds, Moody's cited their registered form, the high proportion held by banks, together with their links to previous debts to banks, and the fact that they account for a high percentage of total Mexican indebtedness. Subsequently Moody's gave $\mathrm{Ba} 2$ ratings to three bond issues by a publicly owned Mexican corporation.

With the growing availability of time series data

108 Among the types of instruments that have been introduced in the context of recent restructuring exercises are partially collateralized bonds, with collateral covering principal and interest obligations, temporary interest reduction bonds, and value recovery facilities. While the range of instruments continues to grow, the number of debt instruments in the market remains considerably smaller than that in existence at the time of the onset of the debt crisis. Analysts have credited the consolidation of debts through multiyear rescheduling agreements in a number of countries, which simplified pricing and documentation procedures, as a significant factor in promoting the early growth of the secondary market. 
on secondary market prices, a body of literature is emerging studying the statistical properties of reported prices. ${ }^{109}$ These studies have highlighted a number of ways in which the price behavior of developing country debt appears to differ from markets for corporate debt. Plausible indicators of creditworthiness, such as lower levels of indebtedness in relation to output, higher per capita income, lower inflation, and a higher rate of growth, have been found to correlate in an expected manner with the relative discounts on claims on various developing countries. But some studies have suggested that discounts are not sensitive to unexpected changes in fundamentals; in particular, according to these studies, unanticipated movements in macroeconomic conditions either in industrial countries or in developing countries do not appear to have strong explanatory powers. The maintenance and intensity of debt conversion programs and the degree to which a country services its obligations in a timely fashion have in most cases been found to correlate positively with both the relative ranking and the movements in prices for individual countries, although one recent study has reported evidence that the introduction of debt conversion schemes has lowered secondary market prices. Some analysts have argued that these latter variables may correlate with the market's perceptions of a debtor's willingness, as opposed to capacity (which might be more closely correlated with macroeconomic indicators), to service its debt. Most analysts have attributed a strong role to increased provisioning on the part of banks in 1987 in explaining the prolonged and sustained decline in prices in that year, although emphasis has varied between seeing increased provisioning as a reflection of the market's perception of impaired value versus seeing provisioning itself as a cause. ${ }^{110}$

\footnotetext{
109 Recent articles include Boehmer and Megginson (1990), Stone (1990), and Froot and Krugman (1990).

110 While announcements of increased provisioning have been cited as important causes of declining secondary market prices, they have generally tended to be associated with
}

After declining sharply from mid-1988 to February 1989, the weighted average price on the secondary market for developing country debt began to recover in March 1989, coinciding with U.S. Treasury Secretary Brady's announcement of proposals for official sector support for debt and debt-service reduction operations and with subsequent decisions by the World Bank and IMF to provide financial assistance for such operations. The upsurge in prices peaked in July 1989 after an agreement in principle was reached between Mexico and its commercial bank creditors. Prices eased later in the year in the wake of the announcements of increased provisioning by major U.S. and U.K. banks, the emergence of interest arrears on the part of Brazil, and uncertainty regarding the financing package for Mexico. After mid-1989, several borrowers that continued to enjoy market access encountered deeper discounts and widened spreads between bid and offer rates. Prices for restructuring countries generally rose in the first half of 1990 in response to the finalization of the debt and debt-service reduction packages for three important debtors, and the actual or intended resumption of debt-equity conversion programs in several debtor countries engaged in privatization programs. Recent aggregate movements in prices have been associated primarily with events in the Middle East, with prices falling sharply in August, reflecting the disposing of claims by a number of Middle Eastern, and, to a lesser extent, Japanese banks. After recovering by the end of the year, prices again fell sharply in midJanuary as traders attempted to reduce their trading portfolios ahead of potential hostilities in the Middle East crisis and in anticipation of possible further distress sales by some banks. Those sales did not materialize, and prices rebounded strongly in February as trading portfolios were reconstituted. Overall, the weighted average secondary market price as of the beginning of March 1991, which stood at 38.9 cents (i.e., a discount of 61.1 percent of face value), was at its highest level since 1988 .

increases in the share prices of the banks making the announcements. 
Statistical Appendix 
Table A1. Long-Term and Short-Term Interest Rate Differentials

Between the United States and Other Major Countries, 1987-90

(In percent a year)

\begin{tabular}{|c|c|c|c|c|}
\hline & Japan & Germany & France & $\begin{array}{l}\text { United } \\
\text { Kingdom }\end{array}$ \\
\hline \multicolumn{5}{|c|}{ Long-term interest rates ${ }^{2}$} \\
\hline 1987 & 2.40 & 1.16 & -1.54 & -2.58 \\
\hline Second quarter & 4.22 & 2.51 & -0.58 & -0.62 \\
\hline Third quarter & 2.91 & 2.38 & -0.95 & -1.00 \\
\hline Fourth quarter & 3.92 & 2.52 & -1.10 & -0.54 \\
\hline \multicolumn{5}{|l|}{1988} \\
\hline First quarter & 4.12 & 2.08 & -0.99 & -1.07 \\
\hline Second quarter & 4.26 & 2.41 & -0.21 & -0.46 \\
\hline Third quarter & 3.58 & 2.37 & 0.05 & -0.85 \\
\hline Fourth quarter & 4.25 & 2.52 & 0.28 & -0.94 \\
\hline \multicolumn{5}{|l|}{1989} \\
\hline First quarter & 4.25 & 2.34 & 0.38 & -0.65 \\
\hline Second quarter & 3.51 & 1.79 & - & -1.53 \\
\hline Third quarter & 3.10 & 1.17 & -0.42 & -1.98 \\
\hline Fourth quarter & 2.56 & 0.53 & -1.12 & -2.74 \\
\hline \multicolumn{5}{|l|}{1990} \\
\hline First quarter & 1.72 & 0.09 & -1.39 & -3.12 \\
\hline Second quarter & 2.07 & -0.06 & -1.00 & -3.65 \\
\hline Third quarter & 1.23 & -0.17 & -1.39 & -3.17 \\
\hline Fourth quarter & 1.29 & -0.59 & -1.81 & -2.79 \\
\hline \multicolumn{5}{|c|}{ Short-term interest rates ${ }^{3}$} \\
\hline \multicolumn{5}{|l|}{1987} \\
\hline First quarter & 1.86 & 1.90 & -2.28 & -4.59 \\
\hline Second quarter & 2.93 & 3.03 & -1.31 & -2.34 \\
\hline Third quarter & 2.88 & 3.02 & -0.98 & -2.86 \\
\hline Fourth quarter & 3.18 & 3.54 & -0.87 & -1.58 \\
\hline \multicolumn{5}{|l|}{1988} \\
\hline First quarter & 2.42 & 3.35 & -1.23 & -2.29 \\
\hline Second quarter & 3.04 & 3.66 & -0.53 & -1.18 \\
\hline Third quarter & 3.43 & 3.31 & 0.52 & -3.16 \\
\hline Fourth quarter & 4.34 & 3.70 & 0.64 & -3.69 \\
\hline \multicolumn{5}{|l|}{1989} \\
\hline First quarter & 5.06 & 3.38 & 0.63 & -3.46 \\
\hline Second quarter & 4.68 & 2.79 & 0.74 & -3.90 \\
\hline Third quarter & 3.32 & 1.59 & -0.42 & -5.20 \\
\hline Fourth quarter & 2.04 & 0.33 & -1.95 & -6.63 \\
\hline \multicolumn{5}{|l|}{1990} \\
\hline First quarter & 1.19 & -0.04 & -2.69 & -6.91 \\
\hline Second quarter & 1.01 & 0.07 & -1.67 & -6.78 \\
\hline Third quarter & 0.17 & -0.30 & -2.09 & -6.90 \\
\hline Fourth quarter & -0.26 & -0.88 & -2.08 & -5.91 \\
\hline \multicolumn{5}{|c|}{$\begin{array}{l}\text { Sources: Banque de France: Nikkei Data Service: Bank of England: Data Resources, Ine. (DRI): U.S. Federal Reserve: and International } \\
\text { Monetary Fund, Treasurer's Department. } \\
\text { 'Differentials shown should be treated as indicative because they conceal intercountry differences in the maturity strueture of long-term } \\
\text { rates. For instance, the U.S. long-term rate is on ten-year federal government bonds, while the German rate is the average on government } \\
\text { bonds with maturities over three years. } \\
\text { 'The long-term interest rates are averages of daily or weekly observations of yields on government bonds specified as follows: France-long- } \\
\text { term (7-10 years) government bond yield: Federal Republic of Germany-yield on government bonds with maturities of } 9 \text {-10 years: Japan- } \\
\text { over-the-counter sales yield of 10-year government bonds, with longest residual maturity: United Kingdom-yield on medium-dated (10 year) } \\
\text { government stock: United States-yield on I0-year treasury bonds. } \\
\text { 'The short-term interest rates are as follows: France-three-month interbank deposit rate: Federal Republic of Germany-three-month } \\
\text { interbank deposit rate; Japan-three-month certificate of deposit rate; United Kingdom-three-month interbank deposit rate; United States- } \\
\text { federal funds rate and three-month certificate of deposit rate. }\end{array}$} \\
\hline
\end{tabular}


Table A2. Volatility of Major Stock Prices, First Quarter 1987Fourth Quarter 1990'

\begin{tabular}{|c|c|c|c|c|c|c|c|}
\hline & $\begin{array}{l}\text { United } \\
\text { States }\end{array}$ & Japan & $\begin{array}{c}\text { United } \\
\text { Kingdom }\end{array}$ & Germany & France & Italy & Canada \\
\hline \multicolumn{8}{|l|}{1987} \\
\hline First quarter & 0.93 & 0.86 & 1.70 & 1.58 & 0.88 & 0.84 & 1.43 \\
\hline Second quarter & 1.12 & 1.30 & 2.07 & 1.47 & 1.07 & 0.88 & 0.66 \\
\hline Third quarter & 0.90 & 1.12 & 3.16 & 0.87 & 0.84 & 1.21 & 0.57 \\
\hline Fourth quarter & 3.65 & 2.83 & 7.31 & 2.97 & 2.43 & 1.99 & 2.69 \\
\hline \multicolumn{8}{|l|}{1988} \\
\hline First quarter & 1.43 & 0.99 & 2.91 & 1.86 & 1.53 & 1.65 & 0.84 \\
\hline Second quarter & 1.16 & 0.62 & 1.20 & 1.04 & 1.24 & 1.05 & 0.63 \\
\hline Third quarter & 0.87 & 0.78 & 1.73 & 0.88 & 0.79 & 0.69 & 0.46 \\
\hline Fourth quarter & 0.76 & 0.57 & 1.22 & 0.82 & 0.65 & 0.76 & 0.59 \\
\hline \multicolumn{8}{|l|}{1989} \\
\hline First quarter & 0.74 & 0.62 & 1.90 & 0.88 & 1.03 & 0.75 & 0.56 \\
\hline Second quarter & 0.73 & 0.57 & 1.86 & 0.71 & 0.71 & 0.49 & 0.44 \\
\hline Third quarter & 0.68 & 0.45 & 1.84 & 0.82 & 0.47 & 0.73 & 0.39 \\
\hline Fourth quarter & 1.09 & 0.57 & 2.73 & 2.27 & 1.16 & 1.36 & 0.67 \\
\hline \multicolumn{8}{|l|}{1990} \\
\hline First quarter & 0.89 & 1.58 & 1.41 & 1.38 & 0.94 & 0.73 & 0.53 \\
\hline Second quarter & 0.77 & 1.58 & 1.88 & 1.33 & 0.80 & 0.54 & 0.70 \\
\hline Third quarter & 1.20 & 2.24 & 2.44 & 1.71 & 1.67 & 1.48 & 0.54 \\
\hline Fourth quarter & 1.10 & 2.59 & 1.30 & 1.62 & 1.07 & 1.30 & 0.57 \\
\hline \multicolumn{8}{|c|}{$\begin{array}{l}\text { Source: Data Resources. Inc. } \\
\text { IFor the United States, the stock market index used is Standard \& Poor's 500: for Japan. Nikkei 225; for the United Kingdom, the Financial } \\
\text { Times Ordinary; for France. CAC General: for Germany. Frankfurt Commerzbank: for ltaly. Banca Commereiale; for Canada. Toronto Stock } \\
\text { Exchange Composite. Volatility is defined as the standard deviation of the daily proportionate changes in stock market indices over the period } \\
\text { indicated. }\end{array}$} \\
\hline
\end{tabular}


Table A3. Stock Market Indices and Interest Rates, August 1-20, 1990

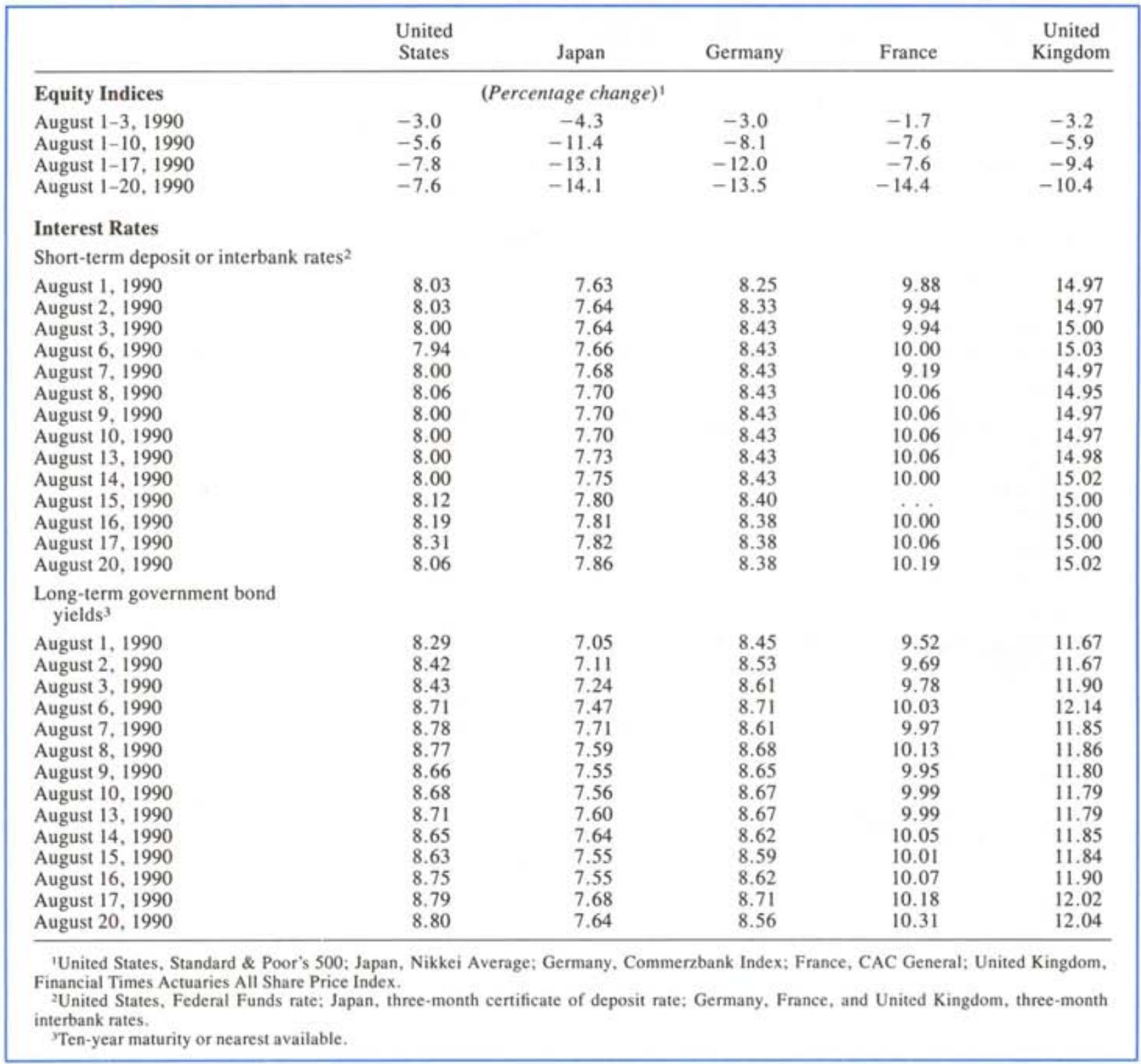


Table A4. United States: Balance of Payments, 1987-Third Quarter 1990 (In billions of U.S. dollars)

\begin{tabular}{|c|c|c|c|c|c|c|c|c|c|c|}
\hline & \multirow[b]{2}{*}{1987} & \multirow[b]{2}{*}{1988} & \multirow[b]{2}{*}{1989} & \multicolumn{4}{|c|}{1989} & \multicolumn{3}{|c|}{1990} \\
\hline & & & & 1 & II & III & IV & 1 & II & III \\
\hline Current account & -162.2 & -129.0 & -110.0 & -22.9 & -27.6 & -31.6 & -28.0 & -17.9 & -21.0 & -30.1 \\
\hline Net direct investments & 15.9 & 42.2 & 40.5 & 14.3 & 6.9 & 1.8 & 17.5 & -4.7 & -0.1 & -12.6 \\
\hline Abroad & -31.0 & -16.2 & -31.7 & -7.0 & -10.1 & -10.6 & -4.0 & -10.2 & -7.4 & -20.2 \\
\hline In the United States & 46.9 & 58.5 & 72.2 & 21.3 & 17.1 & 12.4 & 21.5 & 5.5 & 7.2 & 7.6 \\
\hline Financing need & -146.4 & -86.8 & -69.5 & -8.6 & -20.6 & -29.8 & -10.5 & -22.6 & -21.1 & -42.6 \\
\hline Change in official reserves & 9.1 & -3.9 & -25.3 & -4.0 & -12.1 & -6.0 & -3.2 & -3.2 & 0.3 & 1.7 \\
\hline \multicolumn{11}{|l|}{$\begin{array}{l}\text { Acquisition of liabilities by } \\
\text { foreign monetary }\end{array}$} \\
\hline authorities & 47.7 & 40.2 & 8.5 & 8.0 & -5.4 & 13.4 & -7.4 & -7.8 & 4.5 & 13.4 \\
\hline Residual financing need & -89.5 & -50.5 & -86.3 & -4.6 & -38.1 & -22.5 & -21.1 & -33.6 & -16.4 & -27.5 \\
\hline \multicolumn{11}{|l|}{ Financing } \\
\hline Portfolio investments & 31.1 & 40.3 & 44.8 & 14.0 & 6.6 & 12.5 & 11.8 & -6.7 & -8.1 & -2.7 \\
\hline Public sector bonds & -2.3 & 27.2 & 40.9 & 10.6 & 5.1 & 14.5 & 10.7 & 1.0 & 1.4 & -0.7 \\
\hline Assets & - & - & - & - & - & - & - & - & - & - \\
\hline Liabilities & -2.3 & 27.2 & 40.9 & 10.6 & 5.1 & 14.5 & 10.7 & 1.0 & 1.4 & -0.7 \\
\hline Other bonds & 15.7 & 14.5 & 14.0 & 4.3 & 2.4 & 0.7 & 6.6 & -4.5 & -0.1 & 1.0 \\
\hline Assets & -7.4 & -7.0 & -5.3 & -1.2 & -1.7 & -2.1 & -0.3 & -7.6 & -5.6 & -0.5 \\
\hline Liabilities & 23.1 & 21.4 & 19.3 & 5.5 & 4.1 & 2.8 & 6.8 & 3.2 & 5.5 & 1.4 \\
\hline Corporate equities & 17.7 & -1.4 & -10.1 & -0.9 & -0.9 & -2.7 & -5.5 & -3.3 & -9.4 & -3.0 \\
\hline Assets & 2.1 & -0.9 & -16.7 & -0.9 & -4.5 & -7.5 & -3.8 & 0.1 & -5.7 & -0.5 \\
\hline Liabilities & 15.6 & -0.5 & 6.6 & -0.1 & 3.5 & 4.8 & -1.7 & -3.4 & -3.7 & -2.5 \\
\hline Deposit money banks' & 46.5 & 16.1 & 8.2 & -5.8 & -1.0 & 8.6 & 6.4 & 7.1 & -3.4 & 23.3 \\
\hline Long-term, net & 0.6 & 10.6 & 0.2 & -2.5 & -0.9 & -3.1 & 6.7 & 6.1 & 3.9 & 2.5 \\
\hline Short-term & 45.9 & 5.5 & 8.0 & -3.3 & -0.1 & 11.7 & -0.2 & 1.1 & -7.3 & 20.8 \\
\hline Assets & -40.9 & -57.3 & -41.6 & -15.4 & 24.4 & -13.7 & -36.9 & 41.1 & -11.5 & -6.2 \\
\hline Liabilities & 86.7 & 62.8 & 49.6 & 12.1 & -24.5 & 25.4 & 36.7 & -40.0 & 4.2 & 26.9 \\
\hline Other & 5.3 & 2.5 & 10.8 & 8.0 & 3.6 & -1.1 & 0.3 & 14.2 & -2.0 & 1.9 \\
\hline Errors and omissions & 6.7 & -8.3 & 22.6 & -11.5 & 29.0 & 2.5 & 2.6 & 19.0 & 29.8 & 4.9 \\
\hline
\end{tabular}


Table A5. Japan: Balance of Payments, 1987-Third Quarter 1990 (In billions of U.S. dollars)

\begin{tabular}{|c|c|c|c|c|c|c|c|c|c|c|}
\hline & \multirow[b]{2}{*}{1987} & \multirow[b]{2}{*}{1988} & \multirow[b]{2}{*}{1989} & \multicolumn{4}{|c|}{1989} & \multicolumn{3}{|c|}{1990} \\
\hline & & & & I & II & III & IV & I & II & III \\
\hline Current account & 87.0 & 79.6 & 57.0 & 16.0 & 14.2 & 14.9 & 11.9 & 12.3 & 7.9 & 7.4 \\
\hline Net direct investments & -18.4 & -34.7 & -45.2 & -9.0 & -11.6 & -10.7 & -13.9 & -13.3 & -12.4 & -10.5 \\
\hline Abroad & 19.5 & -34.2 & -44.2 & -8.9 & -11.6 & -10.5 & -13.2 & -13.9 & -12.8 & -10.9 \\
\hline In Japan & 1.2 & -0.5 & -1.1 & -0.2 & - & -0.2 & -0.7 & 0.6 & 0.4 & 0.5 \\
\hline Financing need & 68.7 & 44.9 & 11.8 & 7.0 & 2.6 & 4.2 & -2.1 & -0.9 & -4.6 & -3.1 \\
\hline Change in official reserves & -37.9 & -16.5 & 12.8 & -2.1 & 9.6 & 3.7 & 1.6 & 10.4 & -0.6 & -2.2 \\
\hline $\begin{array}{l}\text { Acquisition of liabilities by } \\
\text { foreign monetary }\end{array}$ & & & & & & & & & & \\
\hline authorities & - & - & - & - & - & - & - & - & - & - \\
\hline Residual financing need & 30.7 & 28.4 & 24.5 & 4.9 & 12.2 & 7.9 & -0.5 & 9.4 & -5.1 & -5.3 \\
\hline \multicolumn{11}{|l|}{ Financing } \\
\hline Portfolio investments ${ }^{1}$ & -91.3 & -52.8 & -32.5 & 7.0 & -7.9 & -12.4 & -19.2 & -6.0 & -10.7 & • \\
\hline Public sector bonds & -62.3 & -106.5 & -95.1 & -15.9 & -26.7 & -20.6 & -31.9 & 5.5 & -4.6 & $\ldots$ \\
\hline Assets & -71.2 & -84.1 & -95.4 & -13.4 & -26.0 & -25.0 & -30.9 & -0.4 & -10.4 & $\ldots$ \\
\hline Liabilities & 8.9 & -22.4 & 0.2 & -2.5 & -0.7 & 4.4 & -1.0 & 5.9 & 5.8 & $\ldots$ \\
\hline Other bond & 30.7 & 49.9 & 73.5 & 13.7 & 31.1 & 12.3 & 16.4 & 5.2 & -4.8 & $\ldots$ \\
\hline Assets & - & - & - & - & - & - & - & - & - & $\ldots$ \\
\hline Liabilities & 30.7 & 49.9 & 73.5 & 13.7 & 31.1 & 12.3 & 16.4 & 5.2 & -4.8 & $\therefore$ \\
\hline Corporate equities & -59.7 & 3.8 & -10.9 & 9.1 & -12.3 & -4.1 & -3.7 & -16.7 & -1.3 & -2.9 \\
\hline Assets & -16.9 & $-3,0$ & -17.9 & 0.1 & -6.1 & -4.8 & -7.1 & -5.0 & -2.2 & 0.5 \\
\hline Liabilities & -42.8 & 6.8 & 7.0 & 9.0 & -6.2 & 0.8 & 3.4 & -11.7 & 0.8 & -3.4 \\
\hline Deposit money banks' & 62.1 & 38.4 & 3.7 & -23.0 & 9.1 & -4.9 & 22.4 & -15.4 & 1.4 & $\cdots$ \\
\hline Long-term, net & -9.7 & -6.1 & -4.9 & -1.3 & -0.6 & -0.1 & -2.9 & -1.5 & -2.1 & $\ldots$ \\
\hline Short-term & 71.8 & 44.5 & 8.6 & -21.7 & 9.7 & -4.8 & 25.3 & -13.9 & 3.4 & 3.0 \\
\hline Assets & -107.1 & -147.5 & -133.9 & -66.6 & 23.0 & -74.3 & -15.9 & -17.9 & 18.9 & -34.7 \\
\hline Liabilities & 178.9 & 191.9 & 142.5 & 45.0 & -13.2 & 69.5 & 41.3 & 4.1 & -15.4 & 37.8 \\
\hline Other & 2.2 & -17.1 & 26.1 & 7.2 & -4.2 & 20.8 & 2.3 & 16.3 & 14.5 & \\
\hline Errors and omissions & -3.7 & 3.1 & -21.8 & 3.9 & -9.2 & -11.5 & -5.1 & -4.4 & - & -6.6 \\
\hline
\end{tabular}

Source: International Monetary Fund, Balance of Payments Statistics; and Bank of Japan, Balance of Pavments Monthly. 'Excluding liabilities held by foreign monetary authorities. 
Table A6. Germany: Balance of Payments, 1987-Third Quarter 1990

(In billions of U.S. dollars)

\begin{tabular}{|c|c|c|c|c|c|c|c|c|c|c|}
\hline & \multirow[b]{2}{*}{1987} & \multirow[b]{2}{*}{1988} & \multirow[b]{2}{*}{1989} & \multicolumn{4}{|c|}{1989} & \multicolumn{3}{|c|}{1990} \\
\hline & & & & I & II & III & IV & I & II & III \\
\hline $\begin{array}{l}\text { Current account } \\
\text { Net direct investments } \\
\text { Abroad } \\
\text { In Germany }\end{array}$ & $\begin{array}{r}46.1 \\
-7.3 \\
-9.2 \\
1.9\end{array}$ & $\begin{array}{r}50.5 \\
-9.9 \\
-11.2 \\
1.4\end{array}$ & $\begin{array}{r}55.4 \\
-7.7 \\
-13.6 \\
5.9\end{array}$ & $\begin{array}{r}16.7 \\
-1.1 \\
-2.7 \\
1.6\end{array}$ & $\begin{array}{r}14.0 \\
-1.9 \\
-2.7 \\
0.7\end{array}$ & $\begin{array}{r}11.1 \\
-2.0 \\
-3.0 \\
0.9\end{array}$ & $\begin{array}{r}13.6 \\
-2.6 \\
-5.2 \\
2.7\end{array}$ & $\begin{array}{r}17.0 \\
-5.5 \\
-5.6 \\
0.1\end{array}$ & $\begin{array}{r}10.8 \\
-2.0 \\
-4.0 \\
2.0\end{array}$ & $\begin{array}{r}8.2 \\
-4.1 \\
-4.3 \\
0.2\end{array}$ \\
\hline $\begin{array}{l}\text { Financing need } \\
\text { Change in official reserves }\end{array}$ & $\begin{array}{r}38.8 \\
-21.5\end{array}$ & $\begin{array}{l}40.6 \\
15.4\end{array}$ & $\begin{array}{r}47.8 \\
-2.8\end{array}$ & $\begin{array}{r}15.6 \\
1.4\end{array}$ & $\begin{array}{r}12.1 \\
-1.5\end{array}$ & $\begin{array}{r}9.1 \\
-0.8\end{array}$ & $\begin{array}{r}11.1 \\
-1.9\end{array}$ & $\begin{array}{r}11.6 \\
-1.4\end{array}$ & $\begin{array}{r}8.8 \\
-2.2\end{array}$ & $\begin{array}{r}4.1 \\
-0.6\end{array}$ \\
\hline $\begin{array}{l}\text { Acquisition of liabilities by foreign } \\
\text { monetary authorities }\end{array}$ & 1.2 & 3.0 & 13.4 & 3.4 & 7.2 & 0.8 & 2.0 & 0.5 & 0.5 & 0.8 \\
\hline Residual financing need & 18.5 & 59.0 & 58.4 & 20.4 & 17.7 & 9.1 & 11.1 & 10.6 & 7.1 & 4.2 \\
\hline \multicolumn{11}{|l|}{ Financing } \\
\hline $\begin{array}{l}\text { Portfolio investments } \\
\text { Public sector bonds }\end{array}$ & $\begin{array}{r}-2.5 \\
11.7\end{array}$ & $\begin{array}{r}-43.8 \\
2.6\end{array}$ & $\begin{array}{r}-4.4 \\
8.9\end{array}$ & $\begin{array}{r}-16.4 \\
-4.1\end{array}$ & $\begin{array}{l}1.1 \\
3.9\end{array}$ & $\begin{array}{r}-1.3 \\
3.3\end{array}$ & $\begin{array}{r}12.2 \\
5.9\end{array}$ & $\begin{array}{l}-8.1 \\
-6.5\end{array}$ & $\begin{array}{r}-6.1 \\
1.7\end{array}$ & $\begin{array}{r}-3.5 \\
2.0\end{array}$ \\
\hline Assets & - & - & - & - & - & - & - & - & - & - \\
\hline Liabilities & 11.7 & 2.6 & 8.9 & -4.1 & 3.9 & 3.3 & 5.9 & -6.5 & 1.7 & 2.0 \\
\hline Other bonds & -12.9 & -39.0 & -21.0 & -10.6 & -2.4 & -6.7 & -1.3 & -6.3 & -4.2 & -2.5 \\
\hline Assets & -13.6 & -31.2 & -21.5 & -9.5 & -2.4 & -7.5 & -2.1 & -5.6 & -4.3 & -3.9 \\
\hline Liabilities & 0.7 & -7.8 & 0.6 & -1.1 & - & 0.9 & 0.8 & -0.7 & 0.1 & 1.3 \\
\hline Corporate equities & -1.3 & -7.3 & 7.6 & -1.7 & -0.4 & 2.1 & 7.6 & 4.7 & -3.5 & -2.9 \\
\hline Assets & -0.1 & -10.3 & -5.0 & -3.0 & -1.2 & -1.0 & 0.2 & 0.3 & -0.6 & $\overline{0}$ \\
\hline Liabilities & -1.2 & 3.0 & 12.6 & 1.3 & 0.8 & 3.1 & 7.4 & 4.3 & -3.0 & -2.9 \\
\hline Deposit money banks ${ }^{1}$ & -8.0 & -2.8 & -25.0 & 12.9 & -7.7 & -6.5 & -23.8 & 7.9 & -7.1 & -3.0 \\
\hline Long-term, net & -1.3 & 6.9 & 6.3 & 2.4 & 1.7 & 1.9 & 0.4 & -4.9 & -1.2 & -5.2 \\
\hline Short-term & -6.7 & -9.6 & -31.3 & 10.6 & -9.4 & -8.4 & -24.1 & 12.8 & -5.9 & 2.2 \\
\hline Assets & -8.8 & -15.8 & -43.2 & 6.9 & -15.1 & -8.4 & -26.7 & 8.1 & -6.1 & -5.9 \\
\hline Liabilities & 2.1 & 6.2 & 12.0 & 3.6 & 5.7 & - & 2.6 & 4.7 & -0.2 & 8.1 \\
\hline Other & -7.1 & -14.9 & -32.1 & -16.2 & -9.7 & -1.5 & -4.7 & -15.3 & 1.3 & -1.9 \\
\hline Errors and omissions & -0.8 & 2.4 & 3.0 & -0.8 & -1.4 & 0.2 & 5.2 & 4.9 & 4.9 & 4.2 \\
\hline
\end{tabular}


Table A7. United Kingdom: Balance of Payments, 1987-Third Quarter 1990 (In billions of U.S. dollars)

\begin{tabular}{|c|c|c|c|c|c|c|c|c|c|c|}
\hline & \multirow[b]{2}{*}{1987} & \multirow[b]{2}{*}{1988} & \multirow[b]{2}{*}{1989} & \multicolumn{4}{|c|}{1989} & \multicolumn{3}{|c|}{1990} \\
\hline & & & & I & II & III & IV & I & II & III \\
\hline Current account & -7.4 & -27.3 & -32.1 & -7.7 & -8.6 & -10.8 & -5.0 & -7.9 & -8.7 & -7.8 \\
\hline Net direct investments & -17.0 & -20.5 & -1.8 & -2.5 & 0.8 & -2.4 & 2.3 & 5.3 & -2.5 & 9.0 \\
\hline Abroad & -31.1 & -37.0 & -32.0 & -11.1 & -8.3 & -6.3 & -6.3 & -7.4 & -7.5 & -4.1 \\
\hline In the United Kingdom & 14.1 & 16.5 & 30.2 & 8.6 & 9.1 & 3.9 & 8.6 & 12.8 & 5.0 & 13.1 \\
\hline Financing need & -24.4 & -47.8 & -33.9 & -10.2 & -7.8 & -13.2 & -2.7 & -2.5 & -11.2 & 1.2 \\
\hline Change in official reserves & -20.2 & -4.9 & 8.8 & 0.9 & 3.5 & 0.6 & 3.9 & 0.2 & -0.1 & -0.8 \\
\hline \multicolumn{11}{|l|}{ Acquisition of liabilities by } \\
\hline foreign monetary authorities & 25.5 & 6.8 & 7.4 & 5.5 & 3.5 & 2.9 & -4.5 & -0.3 & 5.3 & 2.3 \\
\hline Residual financing need & -19.0 & -45.9 & -17.7 & -3.8 & -0.8 & -9.7 & -3.3 & -2.6 & -6.0 & 2.7 \\
\hline \multicolumn{11}{|l|}{ Financing } \\
\hline Portfolio investments ${ }^{\prime}$ & 27.6 & 6.5 & -39.9 & -12.4 & -7.2 & -5.2 & -15.0 & -2.8 & 1.6 & 3.7 \\
\hline Public sector bonds & 3.9 & 1.5 & -2.7 & -0.1 & -1.4 & 0.4 & -1.7 & -2.7 & -0.5 & -1.8 \\
\hline Assets & - & - & - & - & - & - & - & - & - & - \\
\hline Liabilities & 3.9 & 1.5 & -2.7 & -0.1 & -1.4 & 0.4 & -1.7 & -2.7 & -0.5 & -1.8 \\
\hline Other bonds & 11.8 & 1.5 & -12.8 & -0.5 & -11.0 & 4.7 & -6.0 & -5.8 & 3.8 & 0.7 \\
\hline Assets & 4.2 & -12.2 & -27.6 & -3.1 & -12.3 & -3.0 & -9.2 & -8.3 & 1.3 & -3.6 \\
\hline Liabilites & 7.6 & 13.7 & 14.8 & 2.6 & 1.3 & 7.7 & 3.2 & 2.5 & 2.5 & 4.3 \\
\hline Corporate equities & 11.9 & 3.6 & -24.3 & -11.9 & 5.2 & -10.4 & -7.3 & 5.7 & -1.7 & 4.7 \\
\hline Assets & 2.5 & -5.6 & -30.9 & -8.6 & -2.1 & -10.7 & -9.4 & 4.6 & -2.3 & 4.0 \\
\hline Liabilities & 9.4 & 9.1 & 6.5 & -3.2 & 7.3 & 0.3 & 2.1 & 1.1 & 0.6 & 0.7 \\
\hline Deposit money banks' & -18.6 & 18.5 & 20.4 & 5.9 & -3.1 & 11.9 & 5.8 & 6.7 & -9.9 & -11.3 \\
\hline Long-term, net & 1.8 & 1.0 & 1.0 & -0.3 & 0.3 & 0.5 & 0.4 & 0.3 & 0.2 & - \\
\hline Short-term & -20.4 & 17.5 & 19.5 & 6.2 & -3.5 & 11.4 & 5.4 & 6.4 & -10.1 & -11.3 \\
\hline Assets & -86.8 & -35.9 & -50.9 & -26.4 & 1.0 & -14.4 & -11.2 & -14.2 & -5.8 & -54.0 \\
\hline Liabilities & 66.4 & 53.4 & 70.4 & 32.5 & -4.5 & 25.8 & 16.6 & 20.6 & -4.3 & 42.7 \\
\hline Other & -2.4 & 6.9 & 11.4 & 3.3 & 2.5 & 6.8 & -1.3 & 2.1 & -1.7 & -0.3 \\
\hline Errors and omissions & 12.5 & 14.0 & 25.7 & 7.0 & 8.6 & -3.8 & 13.8 & -3.4 & 16.0 & 5.2 \\
\hline
\end{tabular}


Table A8. Change in Interbank Claims and Liabilities, 1984-Third Quarter 1990' (In billions of U.S. dollars)

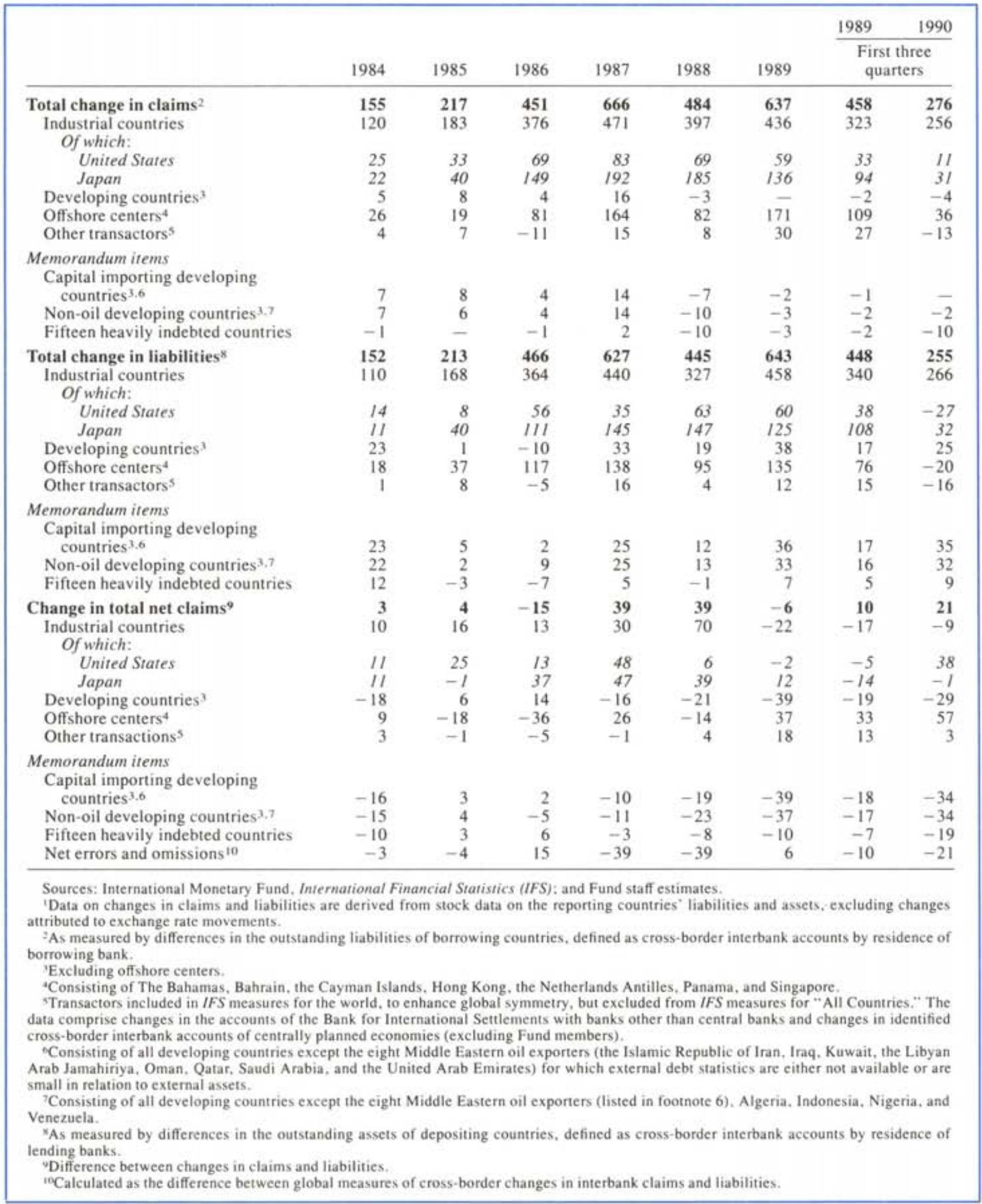


Table A9. Change in Claims on Nonbanks and Liabilities to Nonbanks, 1984-Third Quarter $1990^{\prime}$ (In billions of U.S. dollars)

\begin{tabular}{|c|c|c|c|c|c|c|c|c|}
\hline \multirow{3}{*}{ Total change in claims 2} & \multirow{3}{*}{$\begin{array}{r}1984 \\
28\end{array}$} & \multirow{3}{*}{$\begin{array}{r}1985 \\
59\end{array}$} & \multirow{3}{*}{$\begin{array}{r}1986 \\
87\end{array}$} & \multirow{3}{*}{$\begin{array}{r}1987 \\
137\end{array}$} & \multirow{3}{*}{$\begin{array}{r}1988 \\
76\end{array}$} & \multirow{3}{*}{$\begin{array}{r}1989 \\
183\end{array}$} & 1989 & 1990 \\
\hline & & & & & & & \multicolumn{2}{|c|}{$\begin{array}{l}\text { First three } \\
\text { quarters }\end{array}$} \\
\hline & & & & & & & 123 & 157 \\
\hline $\begin{array}{l}\text { Industrial countries } \\
\text { Of which: }\end{array}$ & & 24 & 37 & 77 & 73 & 128 & 90 & 130 \\
\hline United States & 11 & 21 & 25 & 23 & 39 & 35 & 28 & 21 \\
\hline Japan & -3 & - & 5 & 31 & 17 & 37 & 31 & 35 \\
\hline Developing countries $^{3}$ & 6 & -4 & -2 & 6 & -3 & 12 & 8 & -9 \\
\hline Offshore centers ${ }^{4}$ & 3 & 9 & 5 & 1 & 3 & 10 & 6 & 5 \\
\hline Other transactors ${ }^{5}$ & 2 & 3 & 4 & 3 & -2 & 4 & 2 & 2 \\
\hline Unidentified borrowers ${ }^{6}$ & 5 & 26 & 43 & 50 & 4 & 29 & 17 & 28 \\
\hline \multicolumn{9}{|l|}{ Memorandum items } \\
\hline \multicolumn{9}{|l|}{ Capital importing developing } \\
\hline Non-oil developing countries ${ }^{3.8}$ & 7 & -3 & -1 & 8 & -2 & 11 & 8 & -6 \\
\hline Fifteen heavily indebted countries & 5 & -5 & -1 & 1 & -6 & 1 & - & -17 \\
\hline Total change in liabilities ${ }^{9}$ & 34 & 89 & 118 & 134 & 96 & 158 & 117 & 132 \\
\hline Industrial countries & 9 & 27 & 60 & 53 & 43 & 115 & 79 & 65 \\
\hline \multicolumn{9}{|l|}{ Of which: } \\
\hline United States & -6 & 14 & 26 & 23 & 21 & 6 & 3 & -9 \\
\hline Japan & $I$ & $I$ & 2 & 1 & I & 14 & 5 & -4 \\
\hline Developing countries $^{3}$ & - & 22 & 3 & 15 & 18 & 31 & 22 & 24 \\
\hline Offshore centers ${ }^{4}$ & 6 & 9 & 13 & 7 & 5 & 14 & 11 & 9 \\
\hline Other transactors 5 & - & 1 & -1 & 1 & 2 & 1 & - & 1 \\
\hline Unidentified depositors ${ }^{6}$ & 18 & 31 & 42 & 58 & 28 & -2 & 4 & 33 \\
\hline \multirow{2}{*}{\multicolumn{9}{|c|}{$\begin{array}{l}\text { Memorandum items } \\
\text { Capital importing developing }\end{array}$}} \\
\hline & & & & & & & & \\
\hline countries $^{3.7}$ & 2 & 16 & 6 & 11 & 13 & 21 & 17 & 19 \\
\hline Non-oil developing countries ${ }^{3.8}$ & 1 & 14 & 7 & 11 & 12 & 19 & 15 & 18 \\
\hline Fifteen heavily indebted countries & 3 & 8 & 2 & 5 & 6 & 9 & 8 & 7 \\
\hline Change in total net claims on ${ }^{10}$ & -6 & $-\mathbf{3 0}$ & -31 & 3 & -20 & 24 & 5 & 24 \\
\hline Industrial countries & 4 & -2 & -23 & 24 & 30 & 14 & 11 & 65 \\
\hline \multicolumn{9}{|l|}{ Of which: } \\
\hline United States & 17 & 8 & -1 & 1 & 19 & 28 & 25 & 30 \\
\hline Japan & -3 & -1 & 3 & 30 & 15 & 23 & 25 & 38 \\
\hline Developing countries $^{3}$ & 6 & -26 & -5 & -9 & -22 & -19 & -14 & -33 \\
\hline Offshore centers ${ }^{4}$ & -3 & 1 & -8 & -6 & -2 & -4 & -6 & -4 \\
\hline Other transactors ${ }^{5}$ & 1 & 2 & 5 & 2 & -3 & 3 & 2 & 1 \\
\hline Unidentified (net) ${ }^{6}$ & -14 & -5 & 1 & -8 & -24 & 31 & 12 & -5 \\
\hline \multicolumn{9}{|l|}{$\begin{array}{l}\text { Memorandum items } \\
\text { Capital importing developing }\end{array}$} \\
\hline Capital importing developing & & & & & & & & \\
\hline countries 3.7 & 4 & -19 & -7 & -5 & -16 & -12 & -10 & -28 \\
\hline Non-oil developing countries ${ }^{3.8}$ & 6 & -17 & -8 & -3 & -14 & -8 & -8 & -28 \\
\hline Fifteen heavily indebted countries & 2 & -13 & -3 & -4 & -12 & -8 & -8 & -24 \\
\hline
\end{tabular}

Sources: International Monetary Fund, International Financial Statistics (IFS); and Fund staff estimates.

'Data on changes in claims and liabilities are derived from stock data on the reporting countries' liabilities and assets, excluding changes attributed to exchange rate movements.

${ }^{2}$ As measured by differences in the outstanding liabilities of borrowing countries, defined as cross-border bank credits to nonbanks by residence of borrower.

${ }^{3}$ Excluding offshore centers.

${ }^{4}$ Consisting of The Bahamas, Bahrain, the Cayman Islands, Hong Kong, the Netherlands Antilles, Panama, and Singapore.

sTransactors included in IFS measures for the world, to enhance global symmetry, but excluded from IFS measures for "All Countries." The data comprise changes in the accounts of international organizations (other than the Bank for International Settlements) with banks; and changes in identified cross-border bank accounts of nonbanks in centrally planned economies (excluding Fund members).

'Calculated as the difference between the amount that countries report as their banks' positions with nonresident nonbanks in their monetary statistics and the amounts that banks in major financial centers report as their positions with nonbanks in each country.

'Consisting of all developing countries except the eight Middle Eastern oil exporters (the Islamic Republic of Iran, Iraq, Kuwait, the Libyan Arab Jamahiriya, Oman, Qatar, Saudi Arabia, and the United Arab Emirates) for which external debt statistics are either not available or are small in relation to external assets.

"Consisting of all developing countries except the Middle Eastern oil exporters (see footnote 7), Algeria, Indonesia, Nigeria, and Venezuela,

${ }^{9}$ As measured by differences in the outstanding assets of depositing countries defined as international bank deposits by nonbanks by residence of depositor.

${ }^{10}$ Difference between changes in claims and liabilities. 
Table A10. Change in Cross-Border Bank Claims on and Liabilities to Developing Countries, by Region, 1984-Third Quarter $1990^{1}$

(In billions of U.S. dollars)

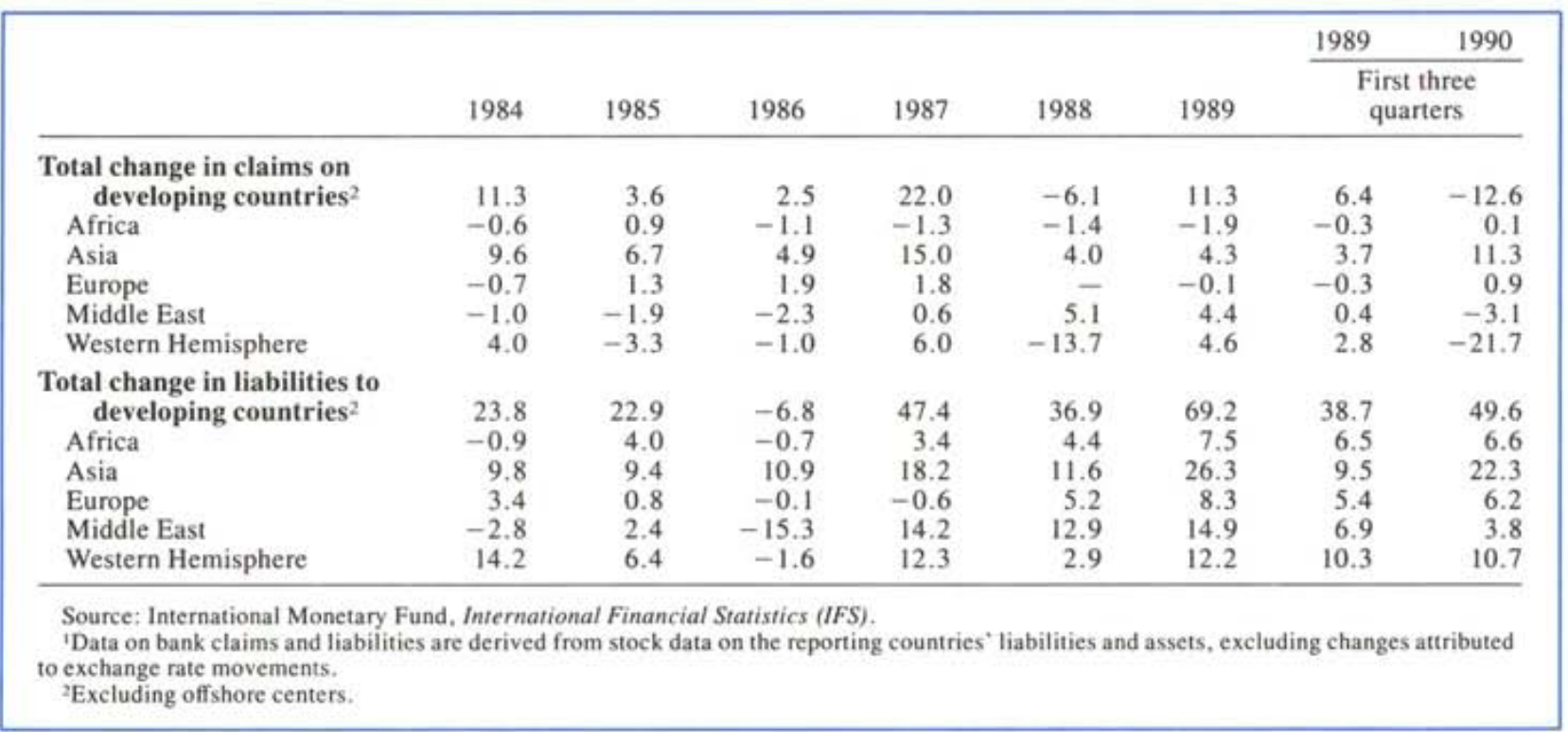




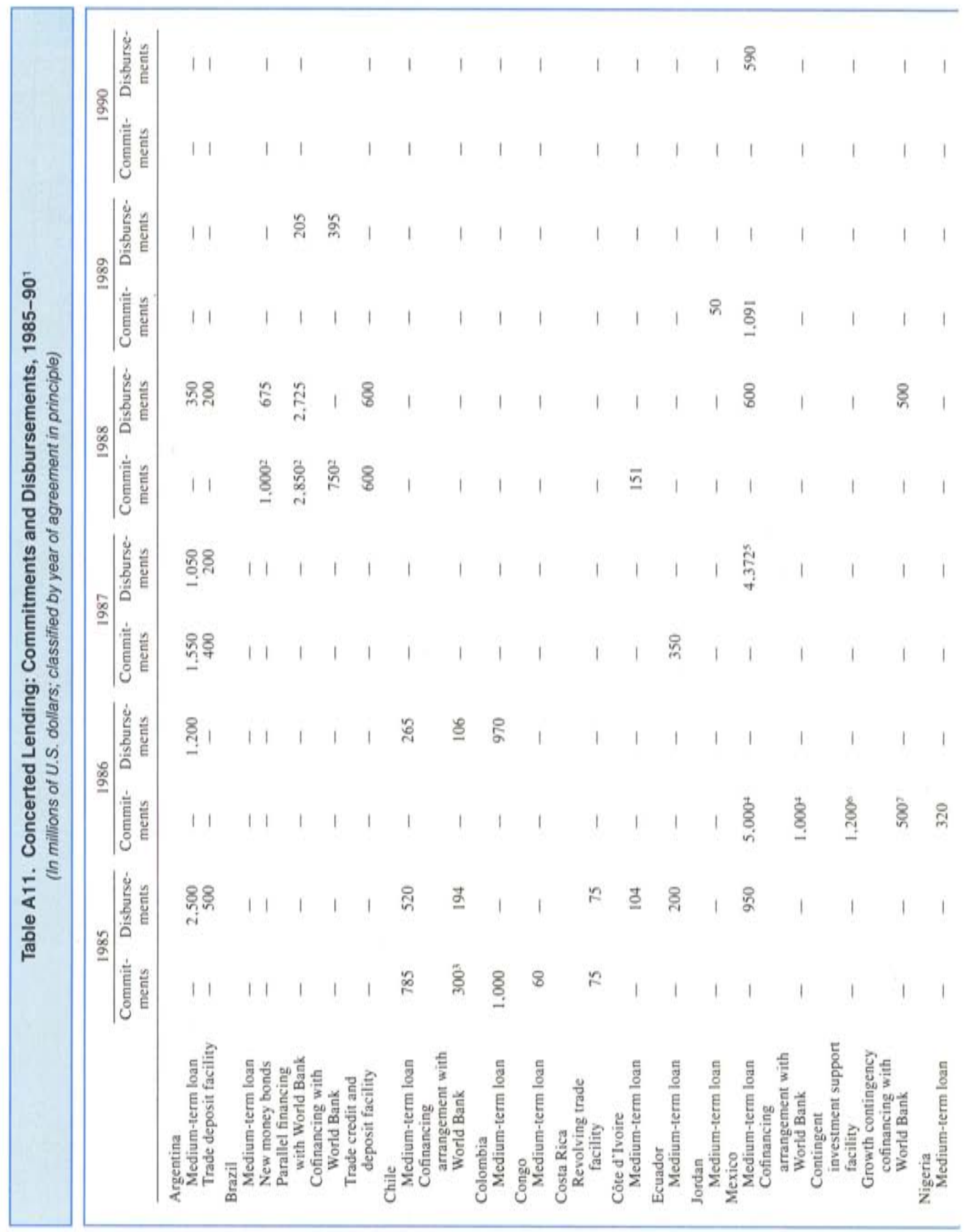




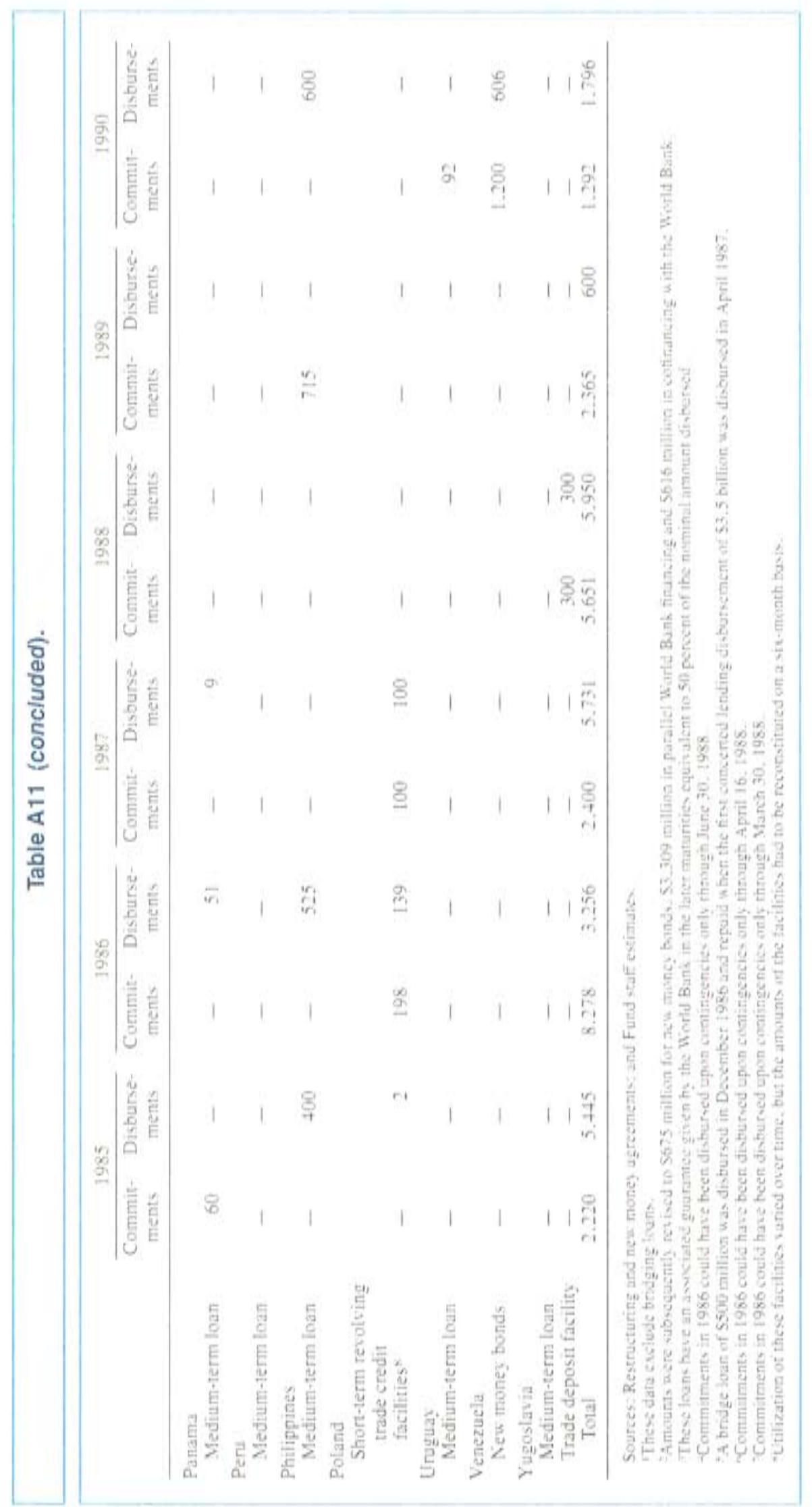


Table A12. U.S. Banks, Developing Country Claims Relative to Capital, 1984-Third Quarter 1990

\begin{tabular}{|c|c|c|c|c|c|c|c|}
\hline & & & & & & & 1990 \\
\hline & 1984 & 1985 & 1986 & 1987 & 1988 & 1989 & $\begin{array}{c}\text { First three } \\
\text { quarters }\end{array}$ \\
\hline & \multicolumn{7}{|c|}{ (In billions of U.S. dollars) } \\
\hline $\begin{array}{l}\text { External claims on developing } \\
\text { countries' }\end{array}$ & 140.8 & 128.8 & 118.6 & 108.8 & 93.2 & 78.8 & 67.7 \\
\hline Total assets & $1,413.0$ & $1,529.0$ & $1,613.0$ & $1,633.0$ & $1,670.3$ & $1,770.0$ & $\mathrm{I}, 802.3$ \\
\hline Capital & 92.2 & \multicolumn{6}{|c|}{ (In percent) } \\
\hline \multicolumn{8}{|l|}{ Memorandum items } \\
\hline Capital to total assets & 6.5 & 6.9 & 7.2 & 7.9 & 8.1 & 8.2 & 8.2 \\
\hline $\begin{array}{l}\text { External claims on developing } \\
\text { countries to total assets }\end{array}$ & 10.0 & 8.4 & 7.4 & 6.7 & 5.6 & 4.5 & 3.8 \\
\hline $\begin{array}{l}\text { Capital to external claims on } \\
\text { developing countries }\end{array}$ & 65.5 & 81.8 & 97.9 & 118.8 & 145.5 & 184.3 & 217.1 \\
\hline
\end{tabular}

Sources: Federal Financial Institutions Examination Council. Country Exposure Lending Survey: and International Monetary Fund, International Financial Statistics.

'Data are based on exposure, that is, claims are adjusted for guarantees and other risk transfers. 


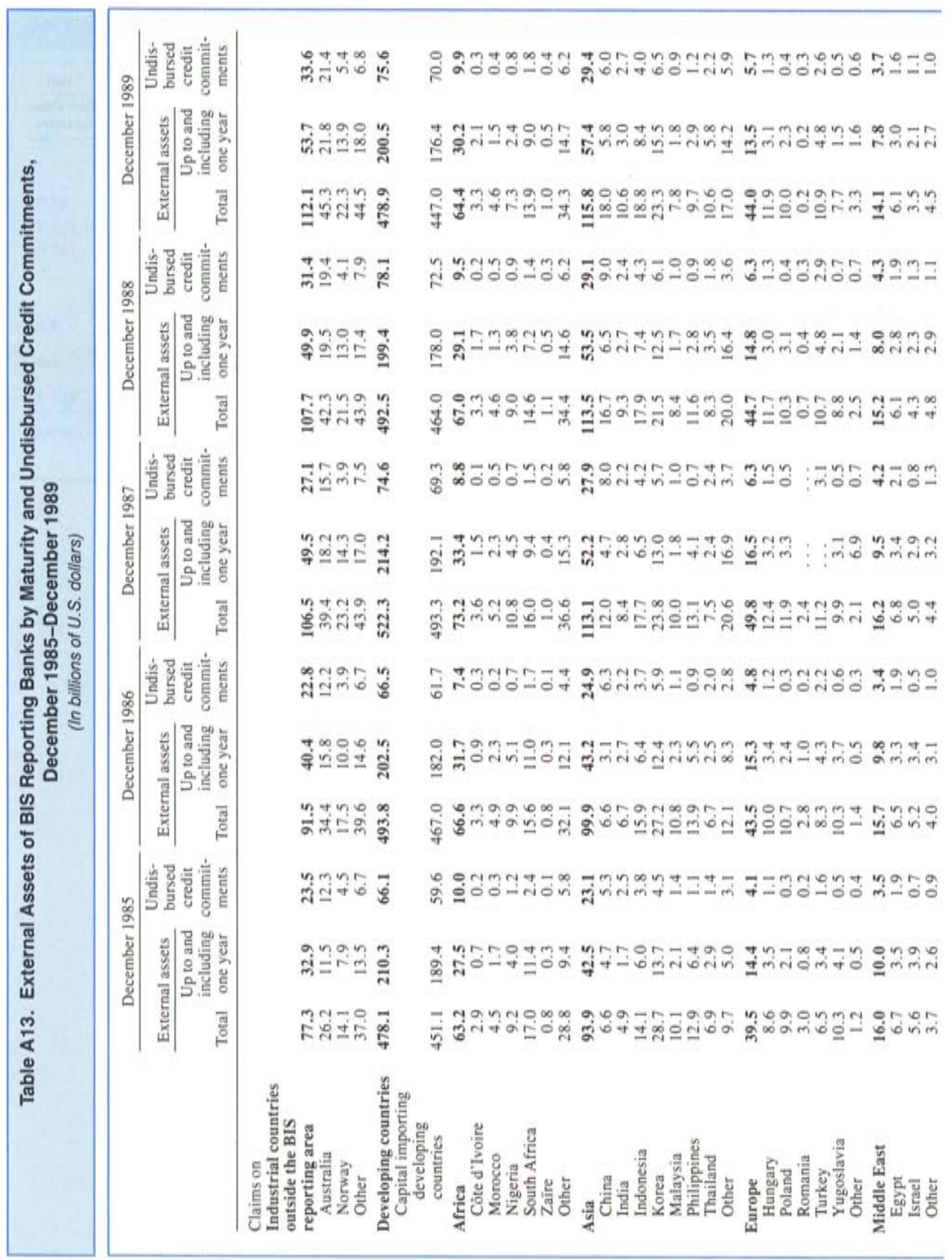




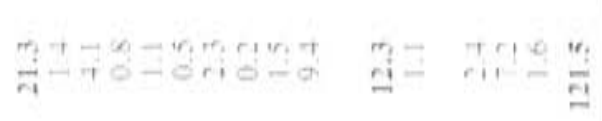

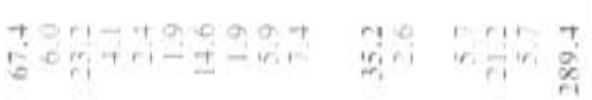

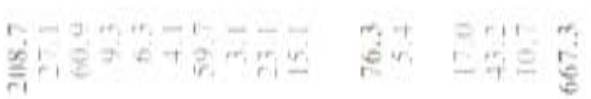

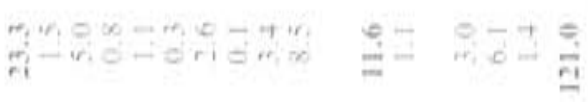

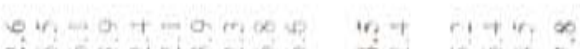

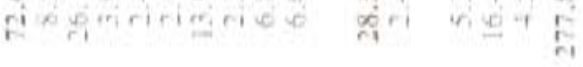

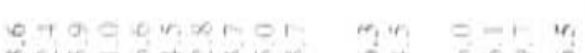

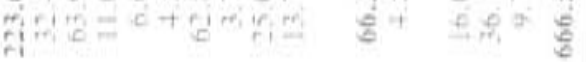

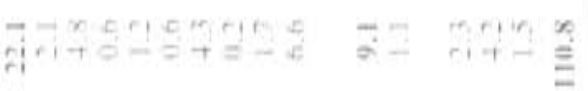

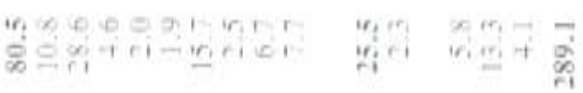

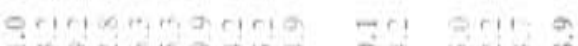

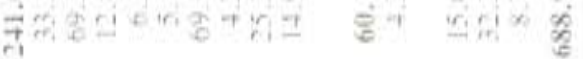

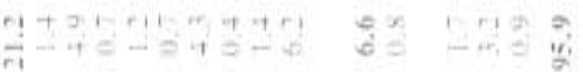

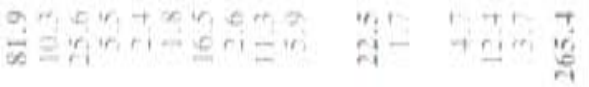

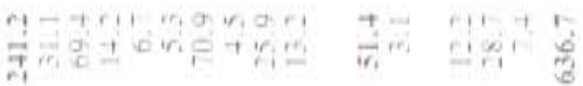

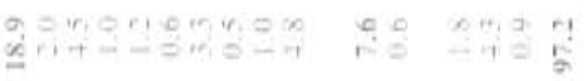

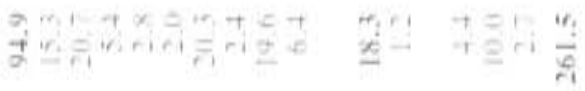

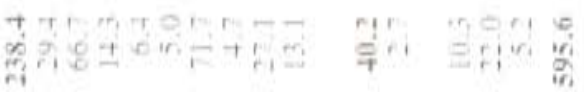

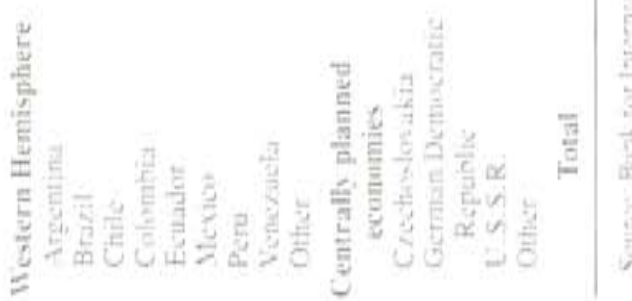


Table A14. Gross International Bond Issues and Placements by Groups of Borrowers, 1985-901 (In millions of U.S. dollars)

\begin{tabular}{|c|c|c|c|c|c|c|}
\hline & 1985 & 1986 & 1987 & 1988 & 1989 & 1990 \\
\hline Foreign bonds & 31,229 & 39,359 & 40,252 & 48,273 & 42,932 & 46,907 \\
\hline Industrial countries & 19.736 & 29.161 & 30,990 & 37,111 & 31.755 & 36,316 \\
\hline Developing countries $^{2}$ & 1,815 & 1.790 & 1.480 & 2.185 & 1.843 & 1.373 \\
\hline International organizations & 9,350 & 8,360 & 7,461 & 8,307 & 8,172 & 8.539 \\
\hline Other & 327 & 48 & 320 & 670 & 1.142 & 680 \\
\hline Eurobonds & 136,543 & 187,747 & 140,535 & 178,869 & 212,853 & 181,870 \\
\hline Industrial countries & 118,194 & 172,020 & 125,293 & 161,190 & 192,653 & 152,606 \\
\hline Developing countries $^{2}$ & 6.681 & 2,989 & 2.459 & 4,074 & 2,871 & 3.834 \\
\hline International organizations & 8,543 & 10,488 & 11,320 & 11,393 & 13,451 & 20,541 \\
\hline Other & 3,124 & 2,250 & 1,463 & 2,213 & 3,878 & 4,889 \\
\hline International bonds & 167,772 & 227,106 & 180,786 & 227,143 & 255,785 & 228,777 \\
\hline Industrial countries & 137,931 & 201.181 & 156.283 & 198,301 & 224,428 & 188,922 \\
\hline Developing countries $^{2}$ & 8.497 & 4,779 & 3,939 & 6.259 & 4.714 & 5,206 \\
\hline International organizations & 17,893 & 18,848 & 18,781 & 19,700 & 21,623 & 29,080 \\
\hline Other & 3,450 & 2.298 & 1.783 & 2,883 & 5.020 & 5.569 \\
\hline
\end{tabular}

Source: Organization for Economic Cooperation and Development, Financial Statistics Monthly,

'The country classifications are those used by the IMF. Excludes special issues by development institutions placed directly with governments or central banks.

'Excludes bonds issued in the context of commercial bank debt restructuring and financing agreements.

\begin{tabular}{|c|c|c|c|c|c|c|}
\hline \multicolumn{7}{|c|}{$\begin{array}{l}\text { Table A15. Early Repayments of International Bonds, 1985-90 } \\
\text { (In billions of U.S. dollars) }\end{array}$} \\
\hline & 1985 & 1986 & 1987 & 1988 & 1989 & 1990 \\
\hline Total (by currency of denomination) & 18.7 & 41.1 & 41.5 & 42.1 & 31.7 & 22.1 \\
\hline U.S. dollar & 17.3 & 34.5 & 24.3 & 23.9 & 17.3 & 13.6 \\
\hline Deutsche mark & 0.5 & 2.3 & 3.9 & 2.5 & 2.0 & 1.8 \\
\hline Swiss franc & 0.3 & 1.5 & 6.2 & 7.1 & 1.5 & 0.2 \\
\hline Japanese yen & 0.3 & 1.6 & 4.7 & 5.2 & 5.9 & 2.1 \\
\hline Pound sterling & 0.1 & 0.2 & 0.7 & 1.5 & 2.3 & 2.1 \\
\hline Other & 0.2 & 1.0 & 1.7 & 1.9 & 2.7 & 2.3 \\
\hline Total (by type of security) & 18.7 & 41.1 & 41.5 & 42.1 & 31.7 & 22.1 \\
\hline Fixed rate bonds & 6.3 & 18.0 & 26.1 & 25.2 & 17.7 & 11.5 \\
\hline Floating rate notes & 11.3 & 19.7 & 10.8 & 14.5 & 10.8 & 7.0 \\
\hline Convertibles & 0.5 & 1.8 & 3.0 & 1.8 & 3.0 & 3.6 \\
\hline Floating rate certificates of deposit & 0.6 & 1.6 & 1.6 & 0.6 & 0.2 & - \\
\hline Total (by country of issuer) & 18.7 & 41.0 & 41.5 & 42.1 & 31.7 & 22.1 \\
\hline Australia & 0.1 & 1.4 & 2.2 & 0.7 & 2.3 & 0.3 \\
\hline Canada & 0.7 & 2.5 & 2.6 & 3.0 & 2.5 & 1.0 \\
\hline Denmark & 1.0 & 1.8 & 1.0 & 1.9 & 0.9 & 0.6 \\
\hline France & 4.0 & 6.7 & 4.6 & 4.2 & 2.8 & 2.8 \\
\hline Italy & - & 2.0 & 0.5 & 2.5 & 0.9 & 1.2 \\
\hline Japan & 1.1 & 3.1 & 3.4 & 2.3 & 1.0 & 0.9 \\
\hline Sweden & 3.4 & 4.0 & 2.3 & 4.1 & 1.0 & 1.3 \\
\hline United Kingdom & 0.8 & 2.4 & 1.5 & 3.8 & 2.2 & 1.8 \\
\hline United States & 3.4 & 6.6 & 7.6 & 5.0 & 7.9 & 6.2 \\
\hline International organizations & 2.3 & 3.6 & 2.4 & 2.4 & 2.5 & 0.8 \\
\hline Other & 1.9 & 6.9 & 13.4 & 12.2 & 7.7 & 5.2 \\
\hline
\end{tabular}

Source: Organization for Economic Cooperation and Development, Financial Market Trends. 
Table A16. Market for Equity-Related Bonds, 1985-90 (In billions of U.S. dollars)

\begin{tabular}{lrrrrrr}
\hline & 1985 & 1986 & 1987 & 1988 & 1989 & 1990 \\
\hline Borrowers, total & 11.3 & $\mathbf{2 6 . 9}$ & $\mathbf{4 3 . 0}$ & $\mathbf{4 1 . 0}$ & $\mathbf{8 0 . 3}$ & $\mathbf{3 0 . 6}$ \\
Japan & 5.9 & 14.9 & $\mathbf{2 8 . 0}$ & 35.6 & $\mathbf{7 5 . 7}$ & 26.3 \\
United States & 3.2 & 3.4 & 4.7 & 0.6 & 0.7 & 0.5 \\
United Kingdom & 0.7 & 1.5 & 4.0 & 0.9 & 1.0 & 2.3 \\
Germany & 1.0 & 1.7 & 1.5 & 0.6 & 0.6 & 0.5 \\
Switzerland & 0.1 & 1.2 & 0.4 & $-\overline{2}$ & $-\overline{3}$ & 0.1 \\
Other OECD countries & 0.4 & 4.2 & 4.4 & 3.2 & 0.3 & 0.1 \\
Other borrowers & - & - & - & 0.1 & 2.0 & 0.8 \\
Currency distribution, total & $\mathbf{1 1 . 3}$ & $\mathbf{2 6 . 9}$ & $\mathbf{4 3 . 0}$ & $\mathbf{4 1 . 0}$ & $\mathbf{8 0 . 3}$ & $\mathbf{3 0 . 6}$ \\
U.S. dollar & 5.3 & 16.4 & 29.2 & 28.8 & 63.5 & 18.1 \\
Swiss franc & 3.9 & 6.5 & 6.8 & 8.1 & 12.3 & 8.1 \\
Deutsche mark & 1.3 & 2.8 & 2.0 & 0.9 & 2.7 & 1.8 \\
Other & 0.8 & 1.2 & 5.0 & 3.2 & 1.8 & 2.6 \\
\hline
\end{tabular}

Source: Organization for Economic Cooperation and Development, Financial Market Trends.

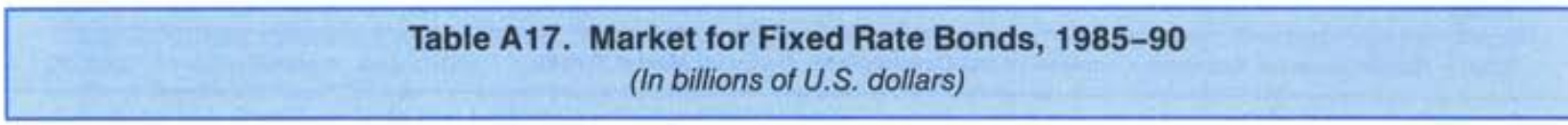

\begin{tabular}{|c|c|c|c|c|c|c|}
\hline & 1985 & 1986 & 1987 & 1988 & 1989 & 1990 \\
\hline Borrowers, total & 94.8 & 141.5 & 121.3 & 160.2 & 154.6 & 160.2 \\
\hline $\begin{array}{l}\text { Industrial countries } \\
\text { Of which: }\end{array}$ & 77.3 & 122.8 & 100.8 & 138.0 & 130.0 & 127.6 \\
\hline Australia & 5.1 & 5.4 & 4.6 & 6.6 & 5.9 & 2.8 \\
\hline Austria & 2.0 & 3.2 & 4.6 & 6.3 & 4.7 & 3.3 \\
\hline Belgium & 0.7 & 2.3 & 3.6 & 2.8 & 2.3 & 2.9 \\
\hline Canada & 7.5 & 13.4 & 8.3 & 12.8 & 12.5 & 12.3 \\
\hline Denmark & 2.2 & 7.2 & 3.9 & 3.9 & 4.3 & 4.2 \\
\hline Finland & 0.9 & 2.8 & 2.6 & 4.3 & 5.0 & 5.9 \\
\hline France & 4.8 & 8.6 & 7.7 & 12.2 & 12.6 & 14.4 \\
\hline Germany & 1.6 & 7.7 & 8.4 & 10.5 & 7.2 & 7.4 \\
\hline Italy & 0.8 & 2.0 & 4.9 & 7.3 & 8.4 & 11.5 \\
\hline Japan & 11.4 & 15.7 & 13.4 & 14.2 & 20.7 & 20.2 \\
\hline Netherlands & 1.2 & 2.5 & 2.8 & 3.6 & 2.8 & 2.0 \\
\hline New Zealand & 1.3 & 3.0 & 2.4 & 1.8 & 1.7 & 0.5 \\
\hline Norway & 1.4 & 4.3 & 3.7 & 5.0 & 2.7 & 0.6 \\
\hline Sweden & 3.9 & 5.5 & 4.4 & 8.1 & 6.0 & 5.1 \\
\hline United Kingdom & 2.5 & 5.1 & 6.2 & 14.0 & 12.3 & 9.0 \\
\hline United States & 26.2 & 29.0 & 14.5 & 14.6 & 13.3 & 17.6 \\
\hline Developing countries & 2.3 & 2.6 & 3.3 & 4.1 & 1.7 & 2.4 \\
\hline Other, including international organizations & 15.2 & 16.1 & 17.2 & 18.1 & 23.0 & 23.0 \\
\hline Currency distribution, total & 94.8 & 141.5 & 121.3 & 160.2 & 154.6 & 160.2 \\
\hline U.S. dollar & 45.1 & 64.1 & 30.9 & 46.7 & 56.8 & 44.5 \\
\hline Japanese yen & 11.3 & 21.9 & 22.6 & 19.9 & 22.2 & 28.8 \\
\hline Swiss franc & 10.5 & 16.4 & 16.9 & 17.7 & 5.9 & 14.7 \\
\hline Deutsche mark & 6.7 & 11.6 & 12.7 & 21.4 & 10.9 & 9.2 \\
\hline ECU & 6.0 & 5.8 & 7.0 & 10.8 & 12.3 & 17.6 \\
\hline Pound sterling & 3.1 & 4.7 & 8.9 & 12.3 & 12.4 & 9.5 \\
\hline Australian dollar & 3.1 & 3.2 & 7.5 & 7.3 & 6.3 & 4.8 \\
\hline Canadian dollar & 2.2 & 5.3 & 5.9 & 13.0 & 11.3 & 6.2 \\
\hline Netherlands guilder & 1.6 & 2.5 & 1.9 & 2.5 & 1.8 & 1.3 \\
\hline Other & 5.2 & 6.0 & 7.0 & 8.6 & 14.7 & 23.6 \\
\hline
\end{tabular}


Table A18. Market for Floating Rate Issues, 1985-90

(In billions of U.S. dollars)

\begin{tabular}{|c|c|c|c|c|c|c|}
\hline & 1985 & 1986 & 1987 & 1988 & 1989 & 1990 \\
\hline Borrowers, total & 58.7 & 51.2 & 13.0 & 22.3 & 17.8 & 36.8 \\
\hline $\begin{array}{l}\text { Industrial countries } \\
\text { Of which: }\end{array}$ & 48.5 & 47.3 & 11.3 & 20.2 & 16.7 & 34.7 \\
\hline Belgium & 1.8 & 1.6 & 0.1 & - & 0.6 & 0.8 \\
\hline Canada & 2.1 & 3.0 & 0.1 & 0.1 & 0.6 & 0.6 \\
\hline Denmark & 0.6 & 1.2 & - & 0.2 & 0.5 & 0.2 \\
\hline France & 6.5 & 4.2 & 0.7 & 2.9 & - & 1.7 \\
\hline Italy & 4.4 & 2.0 & 2.0 & 0.2 & 0.7 & 3.8 \\
\hline Japan & 2.3 & 1.8 & 2.2 & 0.7 & 0.4 & 6.2 \\
\hline Sweden & 2.2 & 0.1 & - & 0.2 & - & 1.0 \\
\hline United Kingdom & 12.2 & 12.8 & 2.4 & 11.4 & 6.8 & 8.7 \\
\hline United States & 10.5 & 10.1 & 2.0 & 1.6 & 1.7 & 3.3 \\
\hline Developing countries & 6.2 & 2.1 & 1.4 & 1.8 & 0.7 & 0.9 \\
\hline Other, including international organizations & 4.0 & 1.8 & 0.3 & 0.3 & 0.4 & 1.2 \\
\hline Currency distribution, total & 58.7 & 51.2 & 13.0 & 22.3 & 17.8 & 36.8 \\
\hline U.S. dollar & 50.5 & 41.1 & 4.6 & 8.4 & 6.3 & 14.2 \\
\hline Pound sterling & 3.4 & 5.7 & 2.0 & 9.9 & 6.3 & 9.9 \\
\hline Deutsche mark & 3.2 & 1.6 & 0.4 & 1.4 & 2.8 & 7.3 \\
\hline $\mathrm{ECU}$ & 1.0 & 1.0 & 0.2 & - & 0.1 & 2.4 \\
\hline Other & 0.6 & 1.8 & 5.8 & 2.6 & 2.3 & 3.0 \\
\hline
\end{tabular}

Table A19. Borrowing on International Markets by Major Instruments, 1985-901

(In percent)

\begin{tabular}{|c|c|c|c|c|c|c|}
\hline & 1985 & 1986 & 1987 & 1988 & 1989 & 1990 \\
\hline Fixed rate bonds & 56.1 & 62.0 & 67.1 & 70.5 & 60.5 & 70.0 \\
\hline Floating rate notes ${ }^{2}$ & 34.7 & 22.4 & 7.2 & 9.8 & 6.9 & 16.1 \\
\hline Equity-related bonds & 6.7 & 11.8 & 23.8 & 18.1 & 31.4 & 13.4 \\
\hline Other bonds ${ }^{3}$ & 2.5 & 3.7 & 1.9 & 1.6 & 1.2 & 0.5 \\
\hline Total & 100.0 & 100.0 & 100.0 & 100.0 & 100.0 & 100.0 \\
\hline
\end{tabular}


Table A20. Gross International Equity Flows, 1986-First Quarter 19901 (In billions of U.S. dollars)

\begin{tabular}{|c|c|c|c|c|c|c|}
\hline & \multirow[b]{2}{*}{1986} & \multirow[b]{2}{*}{1987} & \multirow[b]{2}{*}{1988} & \multirow[b]{2}{*}{1989} & 1989 & 1990 \\
\hline & & & & & \multicolumn{2}{|c|}{ First quarter } \\
\hline \multicolumn{7}{|l|}{ Investor from: } \\
\hline United States & $128.5^{2}$ & $263.3^{2}$ & $191.8^{2}$ & $275.5^{2}$ & $\ldots$ & $\ldots$ \\
\hline Japan $^{3}$ & 34.8 & 125.0 & 150.1 & 176.2 & 35.6 & 50.3 \\
\hline United Kingdom ${ }^{4}$ & 173.6 & 232.9 & 224.1 & 324.1 & 43.4 & 39.3 \\
\hline $\begin{array}{l}\text { Continental Europe } \\
\text { Of which: Germany } 5\end{array}$ & $\begin{array}{r}258.3 \\
42.9\end{array}$ & $\begin{array}{r}369.9 \\
59.4\end{array}$ & $\begin{array}{r}332.6 \\
42.3\end{array}$ & $\begin{array}{r}368.1 \\
65.0\end{array}$ & 15.6 & 17.0 \\
\hline Rest of world & 205.6 & 380.4 & 314.0 & 454.1 & $\cdots$ & $\cdots$ \\
\hline \multicolumn{7}{|l|}{ Equity from: } \\
\hline United States & 277.5 & 481.9 & 363.8 & 416.8 & 91.8 & 90.6 \\
\hline Japan & 189.6 & 354.5 & 327.1 & 432.9 & 114.7 & 88.1 \\
\hline United Kingdom & 84.3 & 144.1 & 120.8 & 141.3 & $\ldots$ & $\cdots$ \\
\hline $\begin{array}{l}\text { Continental Europe } \\
\text { Of which: Germany }\end{array}$ & $\begin{array}{r}185.5 \\
77.9\end{array}$ & $\begin{array}{r}208.9 \\
76.8\end{array}$ & $\begin{array}{r}244.2 \\
60.7\end{array}$ & $\begin{array}{l}343.3 \\
109.2\end{array}$ & 19.6 & 59.7 \\
\hline Rest of world & 60.9 & 155.0 & 156.7 & 263.8 & $\ldots$ & $\ldots$ \\
\hline Total & 800.8 & $1,344.5$ & $1,212.6$ & $1,598.1$ & $\cdots$ & $\cdots$ \\
\hline \multicolumn{7}{|c|}{$\begin{array}{l}\text { Source: Michael Howell and Angela Cozzini, International Equity Flows-1990 Edition: New Investors, New Ris, } \\
\text { (London: Salomon Brothers, August 1990). } \\
\text { 'Gross flows are defined as the sum of equity purchases and sales associated with international portfolio investment. } \\
\text { 'Includes U.S. Employee Retirement Income Security Act (ERISA) funds. } \\
\text { 'Including purchase of Japanese Euro-warrants. } \\
\text { 'Including only pension funds, insurance companies, and open- and closed-ended mutual funds. } \\
\text { 'Excluding investment certificates. }\end{array}$} \\
\hline
\end{tabular}

Table A21. Net International Equity Flows, 1986-First Quarter 19901

(In billions of U.S. dollars)

\begin{tabular}{|c|c|c|c|c|c|c|}
\hline & \multirow[b]{2}{*}{1986} & \multirow[b]{2}{*}{1987} & \multirow[b]{2}{*}{1988} & \multirow[b]{2}{*}{1989} & 1989 & 1990 \\
\hline & & & & & \multicolumn{2}{|c|}{ First quarter } \\
\hline \multicolumn{7}{|l|}{ Investor from: } \\
\hline United States & 2.4 & -1.1 & -0.6 & 20.9 & & \\
\hline Japan $^{2}$ & 7.1 & 16.9 & 3.0 & 17.9 & -0.1 & 4.0 \\
\hline United Kingdom ${ }^{3}$ & 9.5 & -0.3 & 7.2 & 29.8 & 5.7 & 0.8 \\
\hline Continental Europe & 12.0 & 6.8 & 8.1 & 16.4 & $\ldots$ & $\ldots$ \\
\hline Of which: Germany ${ }^{4}$ & 2.3 & -0.2 & 2.8 & 1.6 & 0.8 & -0.3 \\
\hline Rest of world & 0.8 & -18.3 & 3.4 & 7.4 & $\cdots$ & .. \\
\hline \multicolumn{7}{|l|}{ Equity from: } \\
\hline United States & 18.7 & 16.2 & -1.8 & 11.5 & & \\
\hline Japan & -15.8 & -42.8 & 6.8 & 7.0 & 9.0 & -11.7 \\
\hline United Kingdom & 4.3 & 10.0 & 4.3 & 3.1 & -2.0 & 0.1 \\
\hline Continental Europe & 20.3 & 8.7 & 13.0 & 42.1 & $\ldots$ & $\ldots$ \\
\hline Of which: Germany & 6.9 & -1.0 & 3.0 & 12.4 & 1.3 & 4.3 \\
\hline Rest of world & 4.1 & 11.9 & -1.2 & 28.6 & ... & $\ldots$ \\
\hline Total & 31.7 & 4.0 & 21.1 & 92.3 & $\cdots$ & $\cdots$ \\
\hline \multicolumn{7}{|c|}{$\begin{array}{l}\text { Source: Michael Howell and Angela Cozzini, International Equity Flows-1990 Edition: New Investors, New Risks and New Products } \\
\text { (London: Salomon Brothers, August 1990). } \\
\text { INet flows are defined as purchases minus sales of equity associated with international portfolio investment. } \\
\text { 'Including purchase of Japanese Euro-warrants. } \\
\text { Including only pension funds, insurance companies, and open- and closed-ended mutual funds. } \\
\text { 4Excluding investment certificates. }\end{array}$} \\
\hline
\end{tabular}


Table A22. Destination of Cross-Border Mergers and Acquisitions, 1986-First Half 1990 (In billions of U.S. dollars)

\begin{tabular}{|c|c|c|c|c|c|c|}
\hline & \multicolumn{6}{|c|}{ Targets in } \\
\hline & $\begin{array}{l}\text { United } \\
\text { States' }\end{array}$ & Japan & $\begin{array}{c}\text { United } \\
\text { Kingdom }\end{array}$ & $\begin{array}{l}\text { Continental } \\
\text { Europe }\end{array}$ & $\begin{array}{l}\text { Rest of } \\
\text { World }\end{array}$ & Total \\
\hline 1986 & 29.0 & - & 5.9 & 3.2 & 1.1 & 39.2 \\
\hline 1987 & 52.2 & - & 7.1 & 10.2 & 1.3 & 70.9 \\
\hline 1988 & 68.4 & 0.1 & 15.8 & 15.2 & 10.1 & 109.6 \\
\hline 1989 & 59.7 & 0.1 & 28.1 & 24.2 & 5.4 & 117.5 \\
\hline 1990 & & & & & & \\
\hline First Half & 23.9 & - & 9.1 & 32.0 & 4.0 & 69.1 \\
\hline
\end{tabular}

Source: Michael Howell and Angela Cozzini, International Equity Flows-I990 Edition: New Investors, New Risks and New Products (London: Salomon Brothers, August 1990).

'Data for North America. 
Table A23. Financial Futures and Options: Exchanges, Contracts, and Volume of Contracts Traded, 1987-90

\begin{tabular}{|c|c|c|c|c|c|}
\hline \multirow[b]{2}{*}{ Exchange/Type } & \multirow{2}{*}{$\begin{array}{l}\text { Face Value } \\
\text { of Contract' }\end{array}$} & \multicolumn{4}{|c|}{ Volume of Contracts Traded } \\
\hline & & 1987 & 1988 & 1989 & 1990 \\
\hline & & \multicolumn{4}{|c|}{ (In thousands of contracts) } \\
\hline \multicolumn{6}{|l|}{ United States } \\
\hline \multicolumn{6}{|l|}{ Chicago Board of Trade (CBOT) } \\
\hline \multirow{2}{*}{\multicolumn{6}{|c|}{$\begin{array}{l}\text { Interest rate } \\
\text { Futures }\end{array}$}} \\
\hline & & \multicolumn{4}{|c|}{ Futures } \\
\hline Japanese Government bonds ${ }^{2}$ & $¥ 20,000,000$ & n.t. & n.t. & n.t. & 3 \\
\hline U.S. Treasury bonds & $\$ 100,000$ & 66,841 & 70,308 & 70,303 & 75,499 \\
\hline U.S. Treasury notes ${ }^{3}$ & $\$ 100,000$ & 5,254 & 5,708 & 7,891 & 8,698 \\
\hline Municipal bond index & $\$ 1,000 x$ index & 1,613 & 1,274 & 1,068 & 697 \\
\hline Thirty-day interest rate & $\$ 5,000,000$ & n.t. & 19 & 68 & 81 \\
\hline Mortgage-backed & $\$ 100,000$ & n.t. & n.t. & 25 & 17 \\
\hline \multicolumn{6}{|l|}{ Options } \\
\hline U.S. Treasury bonds & $\$ 100,000$ & 21,720 & 19,509 & 20,784 & 27,315 \\
\hline U.S. Treasury notes & $\$ 100,000$ & 1,422 & 1,012 & 1,168 & 1,024 \\
\hline Municipal bond index & $\$ 100,000 x$ index & 119 & 172 & 89 & 86 \\
\hline \multirow{2}{*}{\multicolumn{6}{|c|}{$\begin{array}{l}\text { Stock index } \\
\text { Futures }\end{array}$}} \\
\hline & & & & Futures & \\
\hline Major market (MMI) maxi index & $\$ 250 \mathrm{x}$ index & 2,631 & 1,176 & 1,087 & 951 \\
\hline \multicolumn{6}{|l|}{ Chicago Board Options Exchange (CBOE) } \\
\hline \multirow{2}{*}{\multicolumn{6}{|c|}{$\begin{array}{l}\text { Interest rate } \\
\text { Options }\end{array}$}} \\
\hline & & & & & \\
\hline U.S. Treasury bonds and notes & $\$ 100,000$ & 208 & 140 & 144 & 7 \\
\hline \multicolumn{6}{|l|}{ Stock index } \\
\hline Options & & & & & \\
\hline Standard \& Poor's (S \& P) & & & & & \\
\hline 100 index options & $\$ 100 \mathrm{x}$ index & 0 & 57,434 & 50,745 & 68,847 \\
\hline S \& P 500 index options & $\$ 100 x$ index & 0 & 4,817 & 4,675 & 12,089 \\
\hline Mid-America Commodity Exchange (Mi & & & & & \\
\hline Interest rate & & & & & \\
\hline Futures & & & & & \\
\hline U.S. Treasury bills & $\$ 500,000$ & 26 & 22 & 9 & 4 \\
\hline U.S. Treasury bonds & $\$ 50,000$ & 1.015 & 1,414 & 1,307 & 1,461 \\
\hline U.S. Treasury notes & $\$ 100,000$ & n.t. & 4 & 0 & 0 \\
\hline Currency & & & & & \\
\hline Futures & & & & & \\
\hline Pound sterling & $£ 12.500$ & 11 & 28 & 24 & 26 \\
\hline Swiss franc & Sw F 62,500 & 98 & 77 & 61 & 76 \\
\hline Deutsche mark & DM 62,500 & 85 & 50 & 54 & 83 \\
\hline Japanese yen & $¥ 6,250,000$ & 59 & 44 & 59 & 54 \\
\hline Canadian dollar & Can\$50,000 & 8 & 9 & 7 & 9 \\
\hline Chicago Mercantile Exchange (CME) & & & & & \\
\hline Interest rate & & & & & \\
\hline Futures & & & & & \\
\hline Eurodollar (three-month) ${ }^{4}$ & $\$ 1,000,000$ & 20,416 & 21,705 & 40,818 & 34,696 \\
\hline U.S. Treasury bills & $\$ 1,000,000$ & 1,927 & 1,374 & 1,502 & 1,870 \\
\hline Options & & & & & \\
\hline U.S. Treasury bills & $\$ 1,000,000$ & 12 & 6 & 17 & 32 \\
\hline Eurodollar & $\$ 1,000,000$ & 2.570 & 2,600 & 6,002 & 6,860 \\
\hline Currency & & & & & \\
\hline Futures & & & & & \\
\hline Pound sterling ${ }^{4}$ & $£ 25,000$ & 2,592 & 2,616 & 2,518 & 3,410 \\
\hline Canadian dollar & Can $\$ 100,000$ & 915 & 1,409 & 1,264 & 1,409 \\
\hline Deutsche mark ${ }^{4}$ & DM 125,000 & 6.037 & 5,662 & 8,186 & 9,169 \\
\hline Japanese yen ${ }^{4}$ & $¥ 12,500,000$ & 5,359 & 6,433 & 7,824 & 7,437 \\
\hline Swiss franc & Sw F 125,000 & 5.268 & 5,283 & 6,094 & 6,525 \\
\hline French franc & F 250,000 & 10 & 4 & 2 & 0 \\
\hline Australian dollar & $\$ \mathrm{~A} 100,000$ & 53 & 76 & 114 & 105 \\
\hline Options & & & & & \\
\hline Pound sterling & $£ 25,000$ & 569. & 543 & 406 & 501 \\
\hline Deutsche mark & DM 125,000 & 3,126 & 2,734 & 3,795 & 3,430 \\
\hline Swiss franc & Sw F 125,000 & 1,053 & 1,070 & 1,489 & 1,130 \\
\hline Japanese yen & $¥ 1,250,000$ & 2,251 & 2,945 & 3,127 & 3,116 \\
\hline
\end{tabular}


Table A23 (continued).

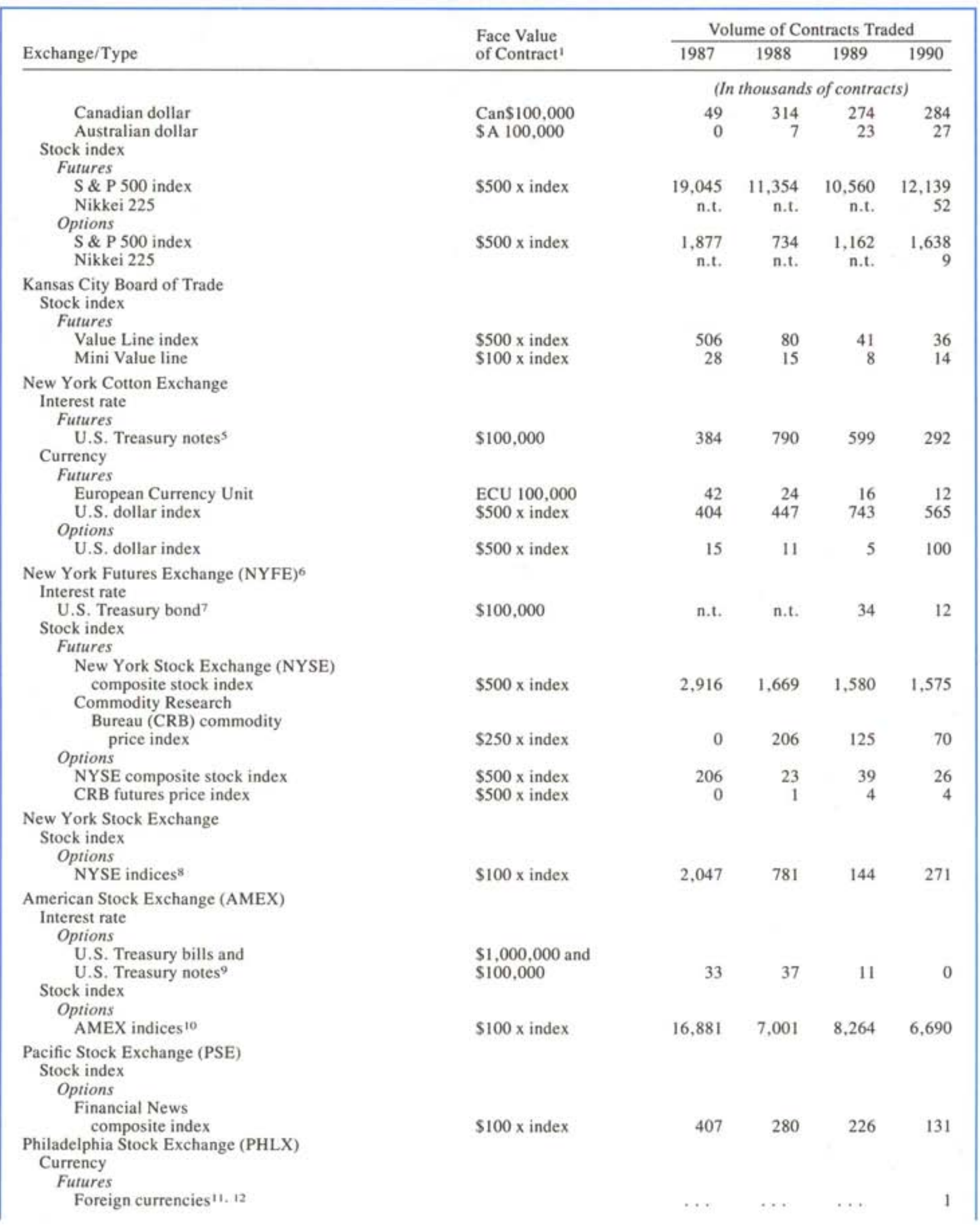


Table A23 (continued).

\begin{tabular}{|c|c|c|c|c|c|}
\hline \multirow[b]{2}{*}{ Exchange/Type } & \multirow{2}{*}{$\begin{array}{l}\text { Face Value } \\
\text { of Contract' }\end{array}$} & \multicolumn{4}{|c|}{ Volume of Contracts Traded } \\
\hline & & 1987 & 1988 & 1989 & 1990 \\
\hline \multirow{2}{*}{\multicolumn{6}{|c|}{ (1) metasanas of comiracis) }} \\
\hline & & & & & \\
\hline Australian dollar & $\$ \mathrm{~A} 100,000$ & 224 & 531 & 417 & 289 \\
\hline Canadian dollar & Can\$100,000 & 318 & 337 & 362 & 371 \\
\hline Deutsche mark & DM 125,000 & 4,260 & 3,407 & 5,277 & 4,875 \\
\hline $\mathrm{ECU}$ & ECU 125,000 & 2 & 1 & 3 & 10 \\
\hline French franc & F 500,000 & 70 & 256 & 47 & 38 \\
\hline Japanese yen & $¥ 12,500,000$ & 2,460 & 2,922 & 3,328 & 2,959 \\
\hline Pound sterling & $\mathrm{f} 31,250$ & 1,876 & 1,303 & 474 & 593 \\
\hline Swiss franc & Sw F 125,000 & 1,304 & 1,237 & 1,114 & 746 \\
\hline \multicolumn{6}{|l|}{ Stock index } \\
\hline \multicolumn{6}{|l|}{ Options } \\
\hline PHLX indices ${ }^{13}$ & $\$ 100 \mathrm{x}$ index & 277 & 3,256 & 153 & 95 \\
\hline \multicolumn{6}{|l|}{ United Kingdom } \\
\hline \multicolumn{6}{|l|}{$\begin{array}{l}\text { London International Financial Futures Exchange } \\
\text { (LIFFE) }\end{array}$} \\
\hline \multirow{2}{*}{\multicolumn{6}{|c|}{$\begin{array}{l}\text { Interest rate } \\
\text { Futures }\end{array}$}} \\
\hline & & & & & \\
\hline ECU (three-month) & ECU $1,000,000$ & n.t. & n.t. & 16 & 64 \\
\hline Eurodollar (three-month) & $\$ 1,000,000$ & 1,739 & 1,648 & 2,064 & 1,249 \\
\hline Eurodeutschemark & DM $1,000,000$ & n.t. & n.t. & 952 & 2,660 \\
\hline German Government bond & DM 250,000 & n.t. & 315 & 5.330 & 9,582 \\
\hline Gilt (government bond) ${ }^{14}$ & $£ 50,000$ & 7,036 & 5,631 & 4,065 & 5,643 \\
\hline Pound sterling (three-month) & $£ 500,000$ & 1.510 & 3,538 & 7,131 & 8,354 \\
\hline U.S. Treasury bonds & $\$ 100,000$ & 1,571 & 2,042 & 967 & 756 \\
\hline \multicolumn{6}{|l|}{ Options } \\
\hline Eurodollar (three-month) & $\$ 1,000,000$ & 40 & 77 & 82 & 65 \\
\hline Eurodeutschemark & DM $1,000,000$ & n.t. & n.t. & n.t. & 248 \\
\hline German Government bond & DM 250,000 & n.t. & n.t. & 469 & 1.804 \\
\hline Gilt & $£ 50,000$ & 1,045 & 1,141 & 727 & 790 \\
\hline U.S. Treasury bonds & $\$ 100,000$ & 56 & 84 & 76 & 88 \\
\hline \multicolumn{6}{|l|}{ Currency } \\
\hline \multicolumn{6}{|l|}{ Futures } \\
\hline Japanese yen & $¥ 12,500,000$ & 6 & 3 & 3 & $\ldots$ \\
\hline Pound sterling & $£ 25,000$ & $\ldots$ & 7 & 5 & 0 \\
\hline Deutsche mark & DM 125,000 & 8 & 4 & 2 & $\ldots$ \\
\hline \multicolumn{6}{|l|}{ Options } \\
\hline Deutsche mark & $\$ 50,000$ & 3 & 2 & & \\
\hline Pound sterling & $£ 25,000$ & 16 & 445 & 824 & 1,377 \\
\hline Stock index & & & & & \\
\hline Futures & & & & & \\
\hline Financial Times stock index & $25 \mathrm{x}$ inde $\mathrm{x}$ & 470 & 465 & 1,028 & 1,444 \\
\hline France & & & & & \\
\hline Marché à Terme d'Instruments Financiers (MATIF) & & & & & \\
\hline Interest rate & & & & & \\
\hline Futures & & & & & \\
\hline French Government bonds & F 500,000 & 11,911 & 12,357 & 15,004 & 15,996 \\
\hline CAC 40 stock index & $\mathrm{F} 200 \mathrm{x}$ index & n.t. & 64 & 581 & 1,642 \\
\hline Paris Interbank Offer Rate (PIBOR) (three-month) & F $5,000,000$ & n.t. & 452 & 2,296 & 1,901 \\
\hline BTAN Treasury note 15 & & n.t. & n.t. & n.t. & 28 \\
\hline ECU bond & & n.t. & n.t. & n.t. & 56 \\
\hline Eurodeutschemark (three-month) & DM $1,000,000$ & n.t. & n.t. & 614 & 394 \\
\hline Options & & & & & \\
\hline Notional bonds & F 500,000 & n.t. & 3,431 & 7,150 & 7,410 \\
\hline Eurodeutschemark (three-month) & DM $1,000,000$ & n.t. & n.t. & n.t. & 109 \\
\hline PIBOR (three-month) & F $5,000,000$ & n.t. & n.t. & n.t. & 710 \\
\hline Japan & & & & & \\
\hline Osaka Securities Exchange & & & & & \\
\hline Stock index & & & & & \\
\hline Futures & & & & & \\
\hline Nikkei 225 stock average & $¥ 1,000 x$ inde $x$ & n.t. & 1.892 & 5,443 & 13.589 \\
\hline
\end{tabular}


Table A23 (continued).

\begin{tabular}{|c|c|c|c|c|c|}
\hline \multirow[b]{2}{*}{ Exchange/Type } & \multirow{2}{*}{$\begin{array}{l}\text { Face Value } \\
\text { of Contract' }\end{array}$} & \multicolumn{4}{|c|}{ Volume of Contracts Traded } \\
\hline & & 1987 & 1988 & 1989 & 1990 \\
\hline & & \multicolumn{4}{|c|}{ (In thousands of contracts) } \\
\hline \multicolumn{6}{|l|}{ Options } \\
\hline Nikkei 225 index & $¥ 1,000 \mathrm{x}$ index & n.t. & n.t. & 6,610 & 9,18 \\
\hline \multirow{2}{*}{\multicolumn{6}{|c|}{$\begin{array}{l}\text { Tokyo International Financial Futures Exchange } \\
\text { Interest rate }\end{array}$}} \\
\hline & & & & & \\
\hline Euro-yen 16 & & n.t. & n.t. & $4,495^{17}$ & 14,4 \\
\hline Eurodollar ${ }^{16}$ & & $\cdots$ & ... & 103 & \\
\hline Japanese yen & & n.t. & n.t. & 17 & \\
\hline \multicolumn{6}{|l|}{ Tokyo Stock Exchange } \\
\hline \multirow{2}{*}{\multicolumn{6}{|c|}{$\begin{array}{l}\text { Interest rate } \\
\text { Futures }\end{array}$}} \\
\hline & & & & & \\
\hline Yen government bonds (ten- and twenty-year) ${ }^{1 \mathrm{~K}}$ & $¥ 100,000,000$ & 18,262 & 17.460 & 18,971 & 16.319 \\
\hline U.S. Treasury bonds & $\$ 100.000$ & n.t. & n.t. & n.t. & 4 \\
\hline \multicolumn{6}{|l|}{ Options } \\
\hline $\begin{array}{l}\text { Yen government bonds (ten-year) } \\
\text { Stock }\end{array}$ & $¥ 100,000,000$ & n.t. & n.t. & n.t. & 1.53 \\
\hline \multicolumn{6}{|l|}{$\begin{array}{l}\text { Stock index } \\
\text { Futures }\end{array}$} \\
\hline Tokyo Stock Price Index (TOPIX) ${ }^{19}$ & $¥ 10,000 \mathrm{x}$ index & n.t. & 2,289 & 3,728 & 3,0 \\
\hline Options & & & & & \\
\hline TOPIX & $¥ 10.000 x$ index & n.t. & n.t. & n.t. & 2 \\
\hline
\end{tabular}

\section{Canada}

Montreal Exchange

Interest rate

Futures

Bankers' Acceptances

Canadian Government bonds

Options

Canadian Treasury bonds

Toronto Futures Exchange

Stock index

Futures

Toronto Stock Exchange TSE 300 spot $^{20}$

TSE 35

Options

TSE 35

The Netherlands

European Options Exchange (EOE)

Interest rate

Options

Dutch Government treasury bonds

Bond index

Currency

Options

U.S. dollar/guilder and pound sterling/guilder

Stock index

Can\$1,000,000

Can\$100,000

Can\$25,000

Can $\$ 10 x$ index

Can $\$ 500 x$ index

Can\$100 $\mathrm{x}$ index

f. 10.000

$\$ 10.000$

f 10,000

f. $100 \times E O E$

EOE stock index and

MMI stock index

Dutch Top 5 index

Financial Futures Market

Interest rate

Deliverable bond (FTO)

Stock index

EOE stock index (FTI)

Dutch Top 5 index

Switzerland

Swiss Options and Financial Futures Exchange

(SOFFEX)

Stock index and $\$ 100 \times \mathrm{MMI}$

f. $100 \times \mathrm{EOE}$

$\begin{array}{rrrr}\text { n.t. } & \text { I0 } & 28 & 88 \\ \text { n.t. } & \text { n.t. } & 87 & 454 \\ 416 & 335 & 323 & 139\end{array}$

$\begin{array}{rrrr}428 & 707 & 2,176 & 2,002 \\ \text { i.t. } & \text { n.t. } & \text { n.t. } & 174\end{array}$

n.t. n.t. $\quad 70 \quad 54$

n.t. $\quad 34 \quad 252 \quad 436$

n.t. n.t. n.t. 43 
Table A23 (continued).

\begin{tabular}{|c|c|c|c|c|c|}
\hline \multirow[b]{2}{*}{ Exchange/Type } & \multirow{2}{*}{$\begin{array}{l}\text { Face Value } \\
\text { of Contract' }\end{array}$} & \multicolumn{4}{|c|}{ Volume of Contracts Traded } \\
\hline & & 1987 & 1988 & 1989 & 1990 \\
\hline & & \multicolumn{4}{|c|}{ (In thousands of contracts) } \\
\hline \multicolumn{6}{|l|}{ Futures } \\
\hline Swiss market index & Sw F $5 x$ indes & n.t. & n.t. & 17 & 30 \\
\hline \multicolumn{6}{|l|}{ Options } \\
\hline Swiss market index & Sw F $5 \mathrm{x}$ inde $\mathrm{x}$ & n.t. & n.t. & 2,115 & 4,655 \\
\hline \multicolumn{6}{|l|}{ Sweden } \\
\hline \multirow{2}{*}{\multicolumn{6}{|c|}{$\begin{array}{l}\text { Stockholm Options Market } \\
\text { Forwards }\end{array}$}} \\
\hline & & & & & \\
\hline \multirow{2}{*}{\multicolumn{6}{|c|}{$\begin{array}{l}\text { Options } \\
\text { Optock nuex }\end{array}$}} \\
\hline & & & & & \\
\hline OMX 30 & SKr $100 x$ index & 6,739 & 4,467 & 5,016 & 5,169 \\
\hline Interest rate options & & n.t. & 204 & 2 & 19 \\
\hline OMX currency options & & n.t. & n.t. & 21 & 5 \\
\hline \multicolumn{6}{|l|}{ Australia } \\
\hline \multicolumn{6}{|l|}{ Sydney Futures Exchange } \\
\hline \multicolumn{6}{|l|}{ Interest rate } \\
\hline \multicolumn{6}{|l|}{ Futures } \\
\hline Bank bills (ninety-day) & $\$ A 500,000$ & 2,094 & 3,014 & 5,911 & 5,015 \\
\hline Commonwealth Treasury bonds (ten-year) & $\$ \mathrm{~A} 100,000$ & 2.061 & 2,957 & 3.219 & 3,093 \\
\hline Semi-government bond & $\$ \mathrm{~A} 100,000+$ coupon & & & & \\
\hline & rate 12 percent a year & n.t. & n.t. & 8 & 6 \\
\hline Treasury bonds (three-year) & $\$$ A $100,000+$ coupon & & & & \\
\hline & rate 12 percent a year & n.t. & 535 & 967 & 1,574 \\
\hline \multicolumn{6}{|c|}{ (2) } \\
\hline Bank bills (ninety-day) & $\$$ A 500,000 & 58 & 193 & 515 & 606 \\
\hline Commonwealth Treasury bonds (ten-year) & $\$ \mathrm{~A} 100,000$ & 37 & 732 & 709 & 512 \\
\hline Treasury bonds (three-year) & $\$ \mathrm{~A} 100,000+$ coupon & & & & \\
\hline & rate 12 percent a year & n.t. & 19 & 25 & 75 \\
\hline Currency & & & & & \\
\hline Futures & & & & & \\
\hline Australian dollar & & 0 & 24 & 5 & 0 \\
\hline Options & & & & & \\
\hline Australian dollar & & 0 & 3 & 0 & 0 \\
\hline Stock index & & & & & \\
\hline Futures & & & & & \\
\hline All-ordinaries index & \$A $100 \mathrm{x}$ index & 616 & 307 & 326 & 310 \\
\hline Options & & & & & \\
\hline All-ordinaries index & $\$ A 100 x$ index & 137 & 83 & 140 & 186 \\
\hline New Zealand & & & & & \\
\hline New Zealand Futures Exchange & & & & & \\
\hline Interest rate & & & & & \\
\hline Futures & & & & & \\
\hline N.Z. Treasury notes & $\$ N Z 100,000$ & 176 & 295 & 349 & 308 \\
\hline Bank bills (ninety-day) & $\$ N Z 500,000$ & 38 & 68 & 118 & 281 \\
\hline Options & & & & & \\
\hline N.Z. Treasury notes & $\$ N Z 100,000$ & n.t. & 1 & 27 & 9 \\
\hline Bank bills (ninety-day) & $\$ N Z 500,000$ & n.t. & n.t. & 2 & 3 \\
\hline Currency & & & & & \\
\hline Futures & & & & & \\
\hline N.Z. dollar & $\$ N Z 100,000$ & n.t. & 0 & 2 & 1 \\
\hline U.S. dollar & $\$ 50,000$ & 16 & 18 & 5 & 4 \\
\hline Stock index & & & & & \\
\hline Futures & & & & & \\
\hline Barclays share index & $\$ N Z 20 x$ index & 120 & 16 & 16 & 14 \\
\hline Options & & & & & \\
\hline Barclays share index & $\$ N Z 20 x$ index & n.t. & n.t. & 3 & 2 \\
\hline Singapore & & & & & \\
\hline Singapore International Monetary Exchange (SIMP & & & & & \\
\hline Interest rate & & & & & \\
\hline Futures & & & & & \\
\hline Eurodollar & $\$ 1,000,000$ & 1,520 & 1,881 & 3,862 & 3,469 \\
\hline Eurodeutschemark & & n.t. & n.t. & n.t. & 57 \\
\hline Euro-yen & & n.t. & 169 & n.t. & 816 \\
\hline
\end{tabular}


Table A23 (concluded).

\begin{tabular}{|c|c|c|c|c|c|}
\hline \multirow[b]{2}{*}{ Exchange/Type } & \multirow{2}{*}{$\begin{array}{l}\text { Face Value } \\
\text { of } \text { Contract }^{1}\end{array}$} & \multicolumn{4}{|c|}{ Volume of Contracts Traded } \\
\hline & & 1987 & 1988 & 1989 & 1990 \\
\hline & & \multicolumn{4}{|c|}{ (In thousands of contracts) } \\
\hline \multicolumn{6}{|l|}{ Options } \\
\hline Eurodollar & $\$ 1,000,000$ & 30 & 11 & 10 & 13 \\
\hline Euro-yen & & n.t. & n.t. & n.t. & 62 \\
\hline \multicolumn{6}{|l|}{ Currency } \\
\hline \multicolumn{6}{|l|}{ Futures } \\
\hline Deutsche mark & DM 125,000 & 131 & 98 & 84 & 64 \\
\hline Japanese yen & $¥ 12,500,000$ & 94 & 221 & 287 & 116 \\
\hline Pound sterling & $£ 62,500$ & 8 & 3 & 3 & 3 \\
\hline \multicolumn{6}{|l|}{ Options } \\
\hline Deutsche mark & DM 125,000 & 7 & 11 & 1 & 0 \\
\hline Japanese yen & $¥ 12,500,000$ & 15 & 61 & 2 & 0 \\
\hline \multicolumn{6}{|l|}{ Stock index } \\
\hline \multicolumn{6}{|l|}{ Futures } \\
\hline Nikkei stock index & $¥ 500 \mathrm{x}$ index & 363 & 587 & 859 & 881 \\
\hline \multicolumn{6}{|l|}{ Hong Kong } \\
\hline \multirow{2}{*}{\multicolumn{6}{|c|}{ Hong Kong Futures Exchange Stock index }} \\
\hline & & & & & \\
\hline Hang Seng stock index & HK\$ $50 \mathrm{x}$ index & 3,611 & 140 & 236 & 236 \\
\hline Hibor (three-month) & HK\$ $1,000,000$ & n.t. & n.t. & n.t. & 55 \\
\hline \multicolumn{6}{|l|}{ Brazil } \\
\hline \multicolumn{6}{|l|}{ Bolsa Mercantile e Futuros (BM\&F) } \\
\hline \multirow{2}{*}{\multicolumn{6}{|c|}{$\begin{array}{l}\text { Interest rate } \\
\text { Futures }\end{array}$}} \\
\hline & & & & & \\
\hline Government Treasury bonds & & n.t. & n.t. & 189 & 711 \\
\hline \multicolumn{6}{|l|}{ Currency } \\
\hline \multicolumn{6}{|l|}{ Futures } \\
\hline U.S. dollar & & n.t. & n.t. & 862 & 608 \\
\hline \multicolumn{6}{|l|}{ Options } \\
\hline U.S. dollar & & n.t. & n.t. & 25 & $\ldots$ \\
\hline \multicolumn{6}{|l|}{ Stock index } \\
\hline \multicolumn{6}{|l|}{ Futures } \\
\hline BM\&F stock index & & n.t. & n.t. & n.t. & 1,233 \\
\hline Bovespa stock index ${ }^{21}$ & & n.t. & n.t. & n.t. & 2,540 \\
\hline
\end{tabular}

Sources: Futures Industry Association, Monthly Volume Report, Monthly Options Report, and International Report; Chicago Board Options Exchange; Euromoney (Corporate Finance Supplement), Futures and Options Directory: Options Clearing Corporation; U.S. Securities and Exchange Commission, Monthly Statistical Review; American Stock Exchange; Philadelphia Stock Exchange; European Options Exchange: New York Stock Exchange; Pacific Stock Exchange; Singapore International Monetary Exchange: Stockholm Options Market; Tokyo International Financial Futures Exchange.

Note: $n . t .=$ not traded; $\$ \mathrm{~A}=$ Australian dollar; CanS $=$ Canadian dollar; $D M=$ deutsche mark; $E C U=$ European Currency Unit; $F=$

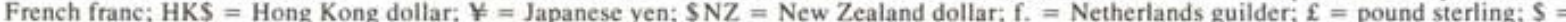
U.S. dollar; and $\mathrm{SKr}=$ Swedish Krone; $\mathrm{Sw} \mathrm{F}=$ Swiss franc. Options volume is puts and calls combined.

'Blanks in this column indicate new financial instruments for which information has not been published in this year's edition of the Futures and Options Directory.

2Trading began September 1990

Includes five-year notes in the 1988, 1989, and 1990 figures; and two-year notes in the 1990 figures.

${ }^{4} \mathrm{CME}$ Eurodollar, pound sterling, deutsche mark, and Japanese yen contracts are listed on a mutual offset link with SIMEX in Singapore.

SIncludes five-year and two-year notes for 1989.

'NYFE is a subsidiary of the New York Stock Exchange.

Thirty-year.

"Includes NYSE composite index and NYSE beta index (discontinued trading in 1988).

U.S. Treasury bills and notes combined.

Toncludes AMEX major market index. AMEX institutional index. AMEX computer technology index. AMEX oil index, Japan index (trading began September 1990), LT20 index (major marketing index divided by 20; trading began November 1990), and international market index (options on an index of American Depository Receipts).

"Covers Australian dollar, Canadian dollar, deutsche mark, ECU, French franc, Japanese yen, pound sterling, and Swiss franc.

12Include European and American options.

1.PHLX value line index. PHLX national OTC index.

${ }^{14} \mathrm{Very}$ few short gilts (with contract size of $£ 100,000$ ), a small number of medium gilts ( $\left.£ 50,000\right)$, mainly long gilts ( $\left.£ 50,000\right)$

isFour-year, fixed interest, with yearly interest payment.

10Three-month.

17Data are for June through December, 1989.

inTrading for the 20-year bond began September 1988.

iv Trading began September 1988 .

sospot and composite index combined.

2'Bolsa de Valores São Paulo. 
Table A24. Outstanding Swap Transactions by Currencies, 1987-89

\begin{tabular}{|c|c|c|c|c|c|c|}
\hline & \multicolumn{2}{|c|}{ December 31,1987} & \multicolumn{2}{|c|}{ December 31,1988} & \multicolumn{2}{|c|}{ December 31, 1989} \\
\hline & $\begin{array}{c}\text { (In millions } \\
\text { of U.S. dollars) }\end{array}$ & $\begin{array}{c}\text { (As percent } \\
\text { of total) }\end{array}$ & $\begin{array}{c}\text { (In millions } \\
\text { of U.S. dollars) }\end{array}$ & $\begin{array}{c}\text { (As percent } \\
\text { of total) }\end{array}$ & $\begin{array}{c}\text { (In millions } \\
\text { of U.S. dollars) }\end{array}$ & $\begin{array}{l}\text { (As percent } \\
\text { of total) }\end{array}$ \\
\hline \multicolumn{7}{|l|}{ Interest rate swaps } \\
\hline U.S. dollar & 541,517 & 79.3 & 728,166 & 72.1 & 993.746 & 66.1 \\
\hline Japanese yen & 40,498 & 5.9 & 78,488 & 7.8 & 128,022 & 8.5 \\
\hline Pound sterling & 29,706 & 4.3 & 52,265 & 5.2 & 100,417 & 6.7 \\
\hline Deutsche mark & 31,640 & 4.6 & 56.466 & 5.6 & 84,620 & 5.6 \\
\hline Other & 39,528 & 5.9 & 94,820 & 9.3 & 195,795 & 13,1 \\
\hline Total & 682,888 & 100.0 & $1,010,203$ & 100.0 & $1,502,600$ & 100.0 \\
\hline \multicolumn{7}{|l|}{ Currency swaps! } \\
\hline U.S. dollar & 162,606 & 88.5 & 269,477 & 84.3 & 354,166 & 78.8 \\
\hline Japanese yen & 59,746 & 32.5 & 131,034 & 41.0 & 201,145 & 44.8 \\
\hline Pound sterling & 10,505 & 5.7 & 17,704 & 5.5 & 33,466 & 7.4 \\
\hline Deutsche mark & 21,377 & 11.6 & 33,979 & 10.6 & 53,839 & 12.0 \\
\hline Other & 113,328 & 61.7 & 187,062 & 58.6 & 256,045 & 57.0 \\
\hline $\begin{array}{l}\text { Total adjusted for } \\
\text { re-exporting } \\
\text { by both sides }\end{array}$ & 183,781 & 200.0 & 319,628 & 200.0 & 449,331 & 200.0 \\
\hline
\end{tabular}


Table A25. Capital/Asset Ratios of Banks in Selected Industrial Countries, 1980-891

(In percent)

\begin{tabular}{|c|c|c|c|c|c|c|c|c|c|c|}
\hline & 1980 & 1981 & 1982 & 1983 & 1984 & 1985 & 1986 & 1987 & 1988 & 1989 \\
\hline Canada $^{2}$ & 3.0 & $3.5^{3}$ & 3.7 & 4.1 & 4.4 & 4.6 & 5.0 & 4.8 & 5.1 & 5.1 \\
\hline France $^{4}$ & 2.1 & 2.0 & 2.2 & 2.4 & 2.7 & 3.7 & 4.5 & 4.9 & 5.4 & 5.6 \\
\hline Germany 5 & 3.3 & 3.3 & 3.3 & 3.3 & 3.4 & 3.5 & 3.6 & 3.7 & 3.7 & 3.8 \\
\hline $\operatorname{Japan}^{6}$ & 5.3 & 5.3 & 5.0 & 5.2 & 5.2 & 4.8 & 4.8 & 4.8 & 4.9 & 5.2 \\
\hline Luxembourg 7 & 3.5 & 3.5 & 3.5 & 3.6 & 3.8 & 4.0 & 4.1 & 4.1 & 4.1 & 4.2 \\
\hline Netherlands ${ }^{8}$ & 4.2 & 4.3 & 4.6 & 4.7 & 4.8 & 5.0 & 5.2 & 5.6 & 5.5 & 5.3 \\
\hline \multicolumn{11}{|l|}{ Switzerland 9} \\
\hline Largest five banks & 7.6 & 7.1 & 7.3 & 7.1 & 7.1 & 7.8 & 7.8 & 7.9 & 8.0 & 8.7 \\
\hline All banks & 7.6 & 7.5 & 7.5 & 7.3 & 7.4 & 7.8 & 7.9 & 8.0 & 8.0 & 8.4 \\
\hline \multicolumn{11}{|l|}{ United Kingdom } \\
\hline Largest four banks 10 & 6.9 & 6.5 & 6.4 & 6.7 & 6.3 & 7.9 & 8.4 & 8.2 & 8.9 & 8.0 \\
\hline All banks" & 5.0 & 4.5 & 4.1 & 4.4 & 4.5 & 5.5 & 5.4 & 6.0 & 6.3 & 6.5 \\
\hline \multicolumn{11}{|l|}{ United States } \\
\hline Nine money-center banks ${ }^{12}$ & 4.5 & 4.6 & 4.9 & 5.4 & 6.2 & 6.8 & 7.3 & 8.2 & 9.2 & 9.3 \\
\hline Next 15 banks 12 & 5.5 & 5.2 & 5.3 & 5.7 & 6.6 & 7.2 & 7.5 & 8.4 & 7.9 & 7.9 \\
\hline All reporting banks 12,13 & 5.4 & 5.4 & 5.6 & 5.9 & 6.5 & 6.9 & 7.2 & 7.9 & 8.1 & 8.2 \\
\hline
\end{tabular}

Sources: Data provided by official sources; and Fund staff estimates.

'Aggregate figures in this table must be interpreted with caution, owing to differences across national groups of banks and over time in the accounting of bank assets and capital. In particular, provisioning practices vary considerably across countries as do the definitions of capital. Therefore, cross-country comparisons may be less appropriate than developments over time within a single country.

${ }^{2}$ Ratio of equity plus accumulated appropriations for contingencies (before 1981, accumulated appropriations for losses) to total assets (Bank of Canada Review).

${ }^{3}$ The changeover to consolidated reporting from November 1, 1981, had the statistical effect of increasing the aggregate capital/asset ratio by about 7 percent.

${ }^{4}$ Ratio of capital reserves, general provisions, and subordinated debentures to total assets. Data exclude cooperative and mutual banks. This ratio is different from the official ratio of risk coverage where assets are assigned different weights depending on the quality of each category.

${ }^{5}$ Ratio of capital including published reserves to total assets. From December 1985, the Bundesbank data incorporate credit cooperatives (Deutsche Bundesbank, Monthly Report).

${ }^{\circ}$ Ratio of reserves for possible loan losses, specified reserves, share capital. legal reserves plus surplus, and profits and losses for the term to total assets (Bank of Japan, Economic Statistics Monthly).

'Ratio of capital resources (share capital, reserves excluding current-year profits, general provisions, and eligibie subordinated loans) to total payable. Eligible subordinated loans may not exceed 50 percent of a bank's share capital and reserves. Data in the table are compiled on a nonconsolidated basis and as a weighted average of all banks (excluding foreign bank branches). An arithmetic mean for 1989 would show a ratio of 10.7 percent. Inclusion of current-year profits in banks' capital resources would result in a weighted average of 4.44 percent for 1989. The level of provisions (as a percentage of exposure) has slightly increased in 1989 as compared with 1988.

sRatio of capital, disclosed free reserves, and subordinated loans to total assets. Eligible liabilities of business members of the agricultural credit institutions are not included (De Nederlandsche Bank, N.V. Annual Report).

${ }^{9}$ Ratio of capital plus published reserves, a part of hidden reserves, and certain subordinated loans to total assets (Swiss National Bank. Monthly Report).

'Ratio of share capital and reserves, plus minority interests and loan capital, to total assets (Bank of England).

"Ratio of capital and other funds (sterling and other currency liabilities) to total assets (Bank of England). Note that these figures include U.K. branches of foreign banks, which normally have little capital in the United Kingdom.

12Ratio of total capital (including equity, subordinated debentures, and reserves for loan losses) to total assets.

13 Reporting banks are all banks that report their country exposure for publication in the Country Exposure Lending Survey of the Federal Financial Institutions Examination Council. 
Table A26. Long-Term Bank Credit Commitments, 1984-90

(In billions of U.S. dollars)

\begin{tabular}{|c|c|c|c|c|c|c|c|}
\hline & 1984 & 1985 & 1986 & 1987 & 1988 & 1989 & 1990 \\
\hline & \multicolumn{7}{|c|}{ (Long-term external credit commitments) } \\
\hline Industrial countries & 32.0 & 32.4 & 40.5 & 54.3 & 95.7 & 97.6 & 90.2 \\
\hline Seven major & 18.2 & 21.2 & 24.3 & 41.3 & 78.5 & 75.5 & 66.7 \\
\hline Other & 13.8 & 11.2 & 16.2 & 13.0 & 17.2 & 22.1 & 23.5 \\
\hline Developing countries ${ }^{t}$ & 29.2 & 16.0 & 22.8 & 16.4 & 17.5 & 18.2 & 17.8 \\
\hline Capital importing' & 28.1 & 14.4 & 21.4 & 16.3 & 17.2 & 16.8 & 17.8 \\
\hline Africa & 0.6 & 1.5 & 1.8 & 0.7 & 0.6 & 0.5 & 0.6 \\
\hline Asia & 9.4 & 7.5 & 8.2 & 8.5 & 7.8 & 8.9 & 10.7 \\
\hline Europe & 1.6 & 2.8 & 2.8 & 4.1 & 2.2 & 2.7 & 1.7 \\
\hline Midḋle East & 0.4 & 0.3 & 0.1 & 0.3 & 0.2 & 0.7 & 0.1 \\
\hline Western Hemisphere & 16.1 & 2.4 & 8.5 & 2.7 & 6.4 & 4.1 & 4.8 \\
\hline Offshore banking centers & 0.9 & 0.4 & 0.7 & 0.3 & 0.4 & 2.4 & 3.0 \\
\hline Other countries n.i.e. & 1.9 & 3.5 & 2.1 & 1.5 & 2.5 & 1.5 & 3.0 \\
\hline International organizations and unallocated & 3.5 & 4.0 & 5.2 & 11.7 & 10.0 & 3.3 & 7.3 \\
\hline \multirow[t]{2}{*}{ Total } & 67.5 & 56.3 & 71.3 & 84.3 & 126.1 & 123.0 & 121.3 \\
\hline & \multicolumn{7}{|c|}{ (Other international long-term bank facilities) } \\
\hline Industrial countries & 48.1 & 44.5 & 25.8 & 27.6 & 14.8 & 7.0 & 4.6 \\
\hline Seven major & 33.9 & 33.6 & 14.4 & 20.0 & 11.3 & 3.7 & 0.6 \\
\hline Other & 14.2 & 10.9 & 11.4 & 7.6 & 3.4 & 3.3 & 4.0 \\
\hline Developing countries' & 6.2 & 2.1 & 3.1 & 1.3 & 1.4 & 0.7 & 1.4 \\
\hline Capital importing ${ }^{1}$ & 5.9 & 1.8 & 3.1 & 1.3 & 1.4 & 0.7 & 1.4 \\
\hline Africa & 0.2 & - & - & - & 0.2 & - & 0.2 \\
\hline Asia & 1.1 & 1.3 & 2.0 & 0.9 & 0.8 & 0.4 & 1.2 \\
\hline Europe & 0.4 & 0.3 & 0.9 & 0.3 & 0.4 & 0.1 & - \\
\hline Middle East & - & - & - & - & - & - & - \\
\hline Western Hemisphere & 4.3 & 0.1 & 0.1 & - & - & 0.2 & - \\
\hline Offshore banking centers & 0.4 & 0.2 & 0.2 & 0.3 & 0.2 & 0.3 & 0.3 \\
\hline Other countries n.i.e. & - & - & 0.5 & 0.2 & 0.2 & 0.1 & - \\
\hline International organizations and unallocated & 0.6 & 2.1 & 0.3 & 1.7 & - & 0.2 & - \\
\hline \multirow[t]{2}{*}{ Total } & 55.3 & 48.9 & 30.0 & 31.2 & 16.6 & 8.4 & 6.3 \\
\hline & \multicolumn{7}{|c|}{ (Total international commitments) } \\
\hline Industrial countries & 80.1 & 76.9 & 66.3 & 81.9 & 110.5 & 104.6 & 94.8 \\
\hline Seven major & 52.1 & 54.8 & 38.7 & 61.3 & 89.8 & 79.2 & 67.3 \\
\hline Other & 28.0 & 22.1 & 27.6 & 20.6 & 20.7 & 25.4 & 27.5 \\
\hline Developing countries' & 35.4 & 18.1 & 25.9 & 17.7 & 18.9 & 18.9 & 19.2 \\
\hline Capital importing' & 34.0 & 16.2 & 24.5 & 17.6 & 18.6 & 17.5 & 19.2 \\
\hline Africa & 0.8 & 1.5 & 1.8 & 0.7 & 0.8 & 0.5 & 0.8 \\
\hline Asia & 10.5 & 8.8 & 10.2 & 9.4 & 8.6 & 9.3 & 11.9 \\
\hline Europe & 2.0 & 3.1 & 3.7 & 4.4 & 2.3 & 2.8 & 1.7 \\
\hline Middle East & 0.4 & 0.3 & 0.1 & 0.3 & 0.2 & 0.7 & 0.1 \\
\hline Western Hemisphere & 20.4 & 2.4 & 8.6 & 2.7 & 6.4 & 4.3 & 4.8 \\
\hline Offshore banking centers & 1.4 & 0.6 & 0.9 & 0.6 & 0.6 & 2.7 & 3.3 \\
\hline Other countries n.i.e. & 1.9 & 3.5 & 2.6 & 1.7 & 2.7 & 1.6 & 3.0 \\
\hline International organizations and unallocated & 4,1 & 6.2 & 5.5 & 13.4 & 10.0 & 3.5 & 7.3 \\
\hline Total & 122.7 & 105.1 & 101.3 & 115.5 & 142.7 & 131.4 & 127.6 \\
\hline
\end{tabular}


Table A27. Bank Credit Commitments by Country of Destination, 1984-901

(In billions of U.S. dollars)

\begin{tabular}{|c|c|c|c|c|c|c|c|}
\hline & 1984 & 1985 & 1986 & 1987 & 1988 & 1989 & 1990 \\
\hline Industrial countries & 32.0 & 32.4 & 40.5 & 54.3 & 95.7 & 97.6 & 90.2 \\
\hline Australia & 2.4 & 2.6 & 5.0 & 3.1 & 3.8 & 8.2 & 2.6 \\
\hline Belgium & 0.9 & 0.7 & 0.8 & 0.3 & 0.9 & 0.5 & 1.1 \\
\hline Canada & 2.7 & 7.0 & 6.2 & 2.1 & 3.9 & 5.9 & 8.3 \\
\hline Denmark & 0.7 & 0.3 & 0.5 & 0.8 & 0.9 & 0.5 & 1.0 \\
\hline France & 2.0 & 4.1 & 3.7 & 3.0 & 7.5 & 5.9 & 6.7 \\
\hline Italy & 4.7 & 5.1 & 6.0 & 5.4 & 4.3 & 7.6 & 13.2 \\
\hline Spain & 3.5 & 2.6 & 4.5 & 1.1 & 1.7 & 1.7 & 1.8 \\
\hline Sweden & 0.4 & 1.0 & 0.1 & 0.5 & 2.3 & 0.7 & 2.7 \\
\hline United Kingdom & 3.3 & 1.5 & 2.2 & 12.9 & 32.1 & 19.8 & 22.4 \\
\hline United States & 5.3 & 3.5 & 5.2 & 15.7 & 28.3 & 32.9 & 11.7 \\
\hline Other & 6.1 & 4.0 & 6.3 & 9.4 & 10.0 & 13.9 & 18.7 \\
\hline Developing countries $^{2}$ & 29.2 & 16.0 & 22.8 & 16.4 & 17.5 & 18.2 & 17.8 \\
\hline $\begin{array}{l}\text { Capital importing developing } \\
\text { countries }^{2}\end{array}$ & 28.1 & 14.4 & 21.4 & 16.3 & 17.2 & 16.8 & 17.8 \\
\hline Africa & 0.6 & 1.5 & 1.8 & 0.7 & 0.6 & 0.5 & 0.6 \\
\hline Côte d'Ivoire & 0.1 & 0.1 & - & - & 0.2 & - & - \\
\hline Morocco & - & 0.1 & - & - & 0.1 & - & 0.1 \\
\hline Nigeria & $\overline{0}$ & - & 0.3 & - & - & - & - \\
\hline South Africa & 0.2 & - & - & - & - & - & - \\
\hline Other & 0.3 & 1.3 & 1.5 & 0.7 & 0.3 & 0.5 & 0.5 \\
\hline Asia & 9.4 & 7.5 & 8.2 & 8.5 & 7.8 & 8.9 & 10.7 \\
\hline China & 0.2 & 2.3 & 1.9 & 3.3 & 2.7 & 1.6 & 1.3 \\
\hline India & 0.6 & 0.2 & 1.2 & 1.8 & 1.6 & 1.4 & 0.7 \\
\hline Indonesia & 1.6 & 0.1 & 1.0 & 1.6 & 0.5 & 2.3 & 3.9 \\
\hline Korea & 3.7 & 3.7 & 1.5 & 0.9 & 1.2 & 0.7 & 1.9 \\
\hline Malaysia & 1.0 & 0.2 & 1.2 & 0.3 & 0.8 & 0.1 & 0.5 \\
\hline Philippines & 0.9 & - & - & - & - & 0.7 & - \\
\hline Thailand & 0.8 & 0.7 & 1.1 & 0.3 & 0.8 & 0.8 & 1.2 \\
\hline Other & 0.6 & 0.3 & 0.3 & 0.3 & 0.2 & 1.3 & 1.2 \\
\hline Europe & 1.6 & 2.8 & 2.8 & 4.1 & 2.2 & 2.1 & 1.7 \\
\hline Hungary & 0.8 & 0.9 & 0.8 & 1.4 & 0.2 & 0.8 & - \\
\hline Turkey & 0.4 & 1.6 & 2.0 & 2.6 & 1.7 & 1.7 & 1.6 \\
\hline Yugoslavia & - & - & - & - & 0.3 & - & - \\
\hline Other & 0,4 & 0.3 & - & 0.1 & - & 0.2 & 0.1 \\
\hline Middle East & 0.4 & 0.3 & 0.1 & 0.3 & 0.2 & 0.7 & 0.1 \\
\hline Egypt & - & 0.1 & - & - & - & 0.5 & - \\
\hline Jordan & 0.3 & 0.2 & - & 0.2 & 0.2 & 0.1 & - \\
\hline Other & - & - & 0.1 & 0.1 & - & 0.1 & 0.1 \\
\hline Western Hemisphere & 16.1 & 2.4 & 8.5 & 2.7 & 6.4 & 4.6 & 4.8 \\
\hline Argentina & 4.2 & - & - & 2.1 & - & - & - \\
\hline Brazil & 6.5 & - & - & - & 5.2 & 0.1 & - \\
\hline Chile & 0.8 & 1.1 & - & - & 0.2 & - & 0.3 \\
\hline Colombia & 0.4 & 1.1 & 0.2 & 0.1 & 1.0 & 1.6 & 1.8 \\
\hline Ecuador & 0.2 & - & 0.2 & 0.4 & - & - & - \\
\hline Mexico & 3.8 & - & 7.7 & - & - & 1.3 & 0.5 \\
\hline Peru & - & - & - & - & - & - & - \\
\hline Venezuela & - & - & - & - & - & - & 1.4 \\
\hline Other & 0.2 & 0.2 & 0.4 & 0.1 & - & 1.1 & 0.8 \\
\hline
\end{tabular}


Table A27 (concluded).

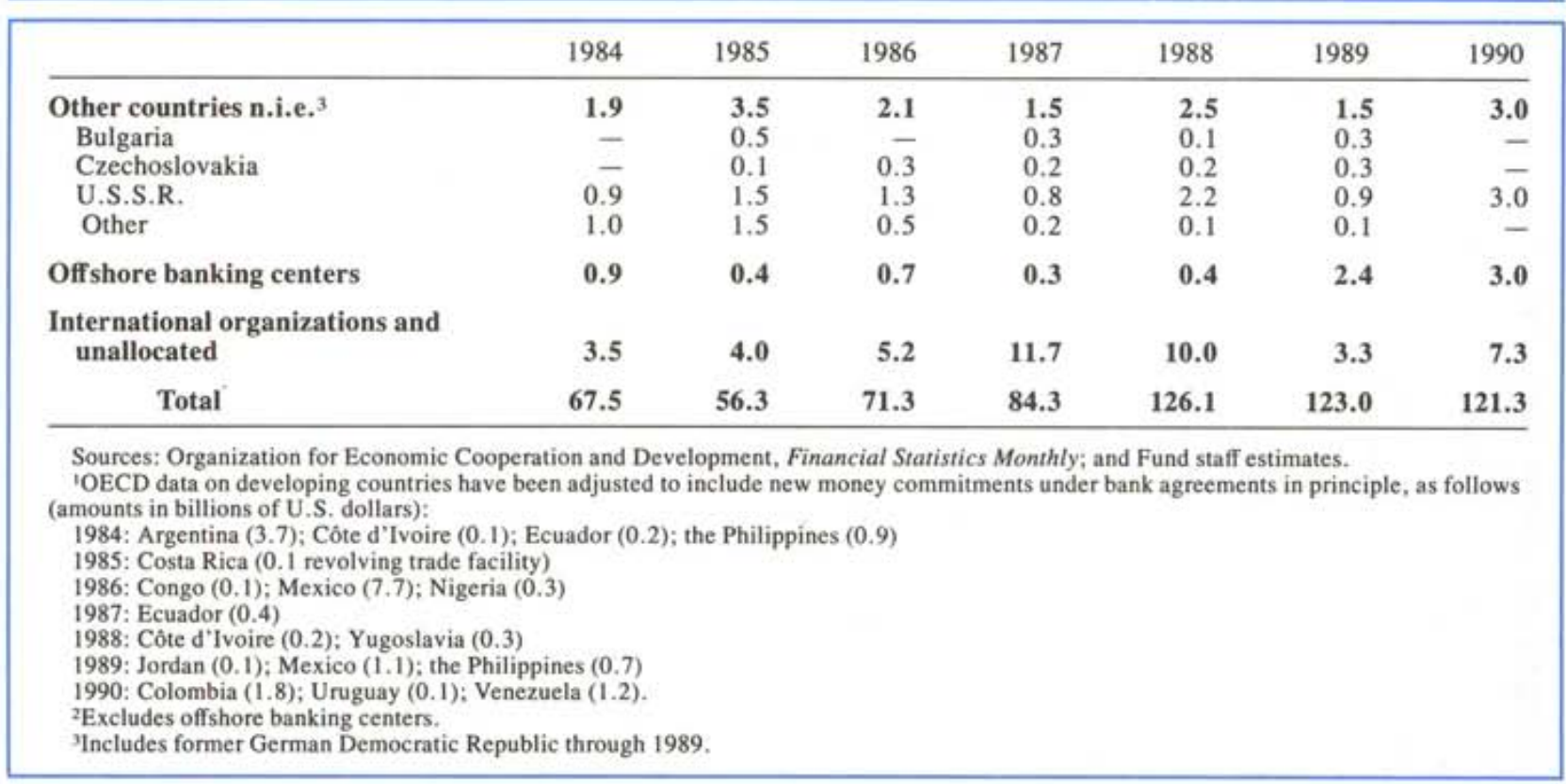

Table A28. Terms of Long-Term Bank Credit Commitments, 1984-901

\begin{tabular}{|c|c|c|c|c|c|c|c|}
\hline & 1984 & 1985 & 1986 & 1987 & 1988 & 1989 & 1990 \\
\hline Average maturity (in years) & 7.8 & 7.8 & 6.7 & 8.3 & 5.7 & 6.2 & 6.5 \\
\hline OECD countries & 7.2 & 7.4 & 6.3 & 7.5 & 5.1 & 5.8 & 5.8 \\
\hline Eastern Europe & 5.9 & 7.4 & 7.8 & 8.1 & 8.4 & 8.3 & 11.9 \\
\hline Developing countries & 8.5 & 8.4 & 8.2 & 10.7 & 9.0 & 7.3 & 8.6 \\
\hline Other & 6.5 & 7.3 & 6.8 & 6.1 & 6.5 & 8.8 & 6.6 \\
\hline Average spread (basis points) & 92 & 62 & 41 & 42 & 35 & 56 & 52 \\
\hline OECD countries & 57 & 47 & 37 & 34 & 31 & 54 & 51 \\
\hline Eastern Europe & 93 & 55 & 26 & 24 & 30 & 49 & 50 \\
\hline Developing countries & 132 & 92 & 61 & 68 & 65 & 68 & 60 \\
\hline Other & 88 & 56 & 33 & 48 & 42 & 32 & 47 \\
\hline \multicolumn{8}{|l|}{ Memorandum items (in percent) } \\
\hline \multicolumn{8}{|l|}{ Six-month Eurodollar } \\
\hline interbank rate (average) & 11.29 & 8.64 & 6.85 & 7.30 & 8.13 & 9.27 & 8.35 \\
\hline U.S. prime rate (average) & 12.04 & 9.93 & 8.35 & 8.21 & 9.32 & 10.92 & 10.01 \\
\hline
\end{tabular}




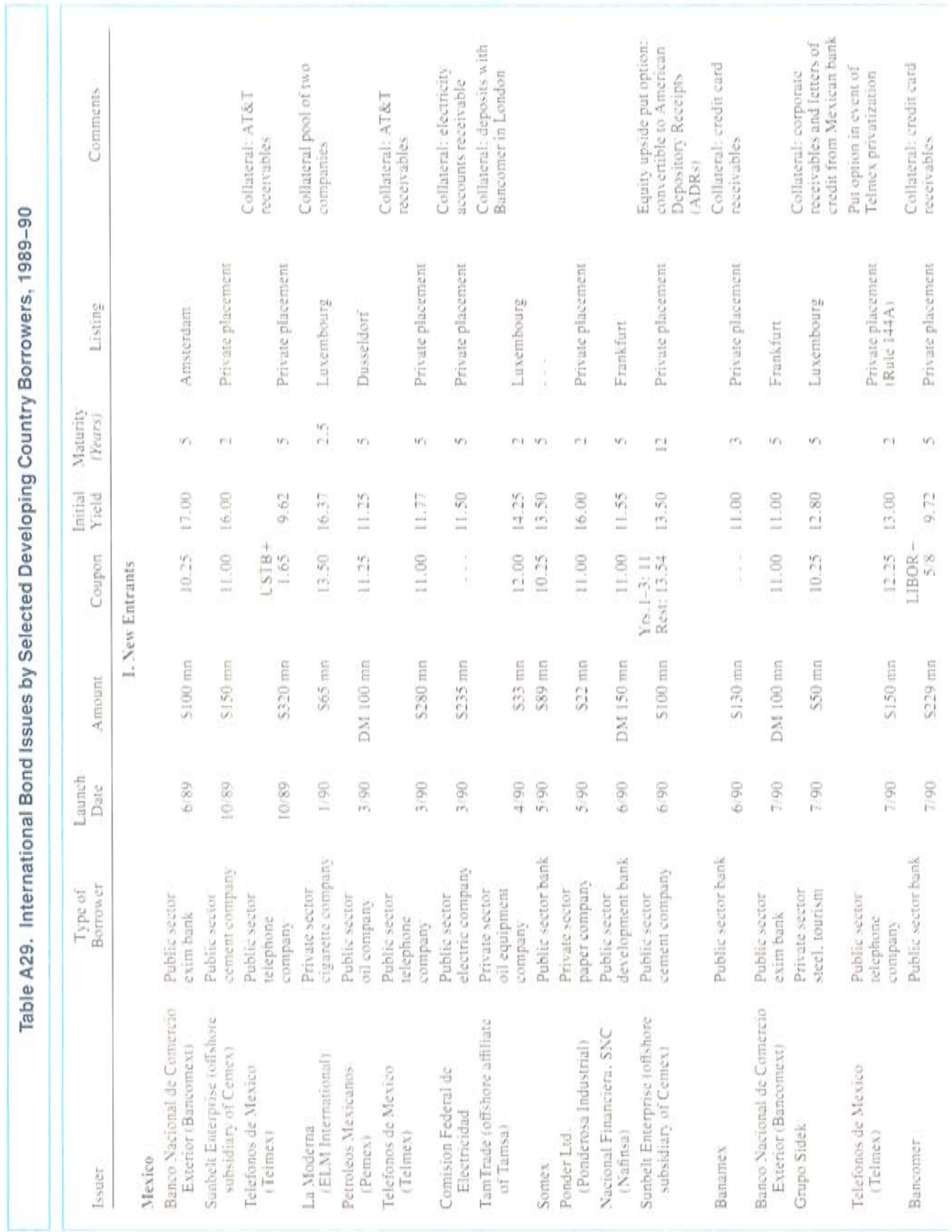



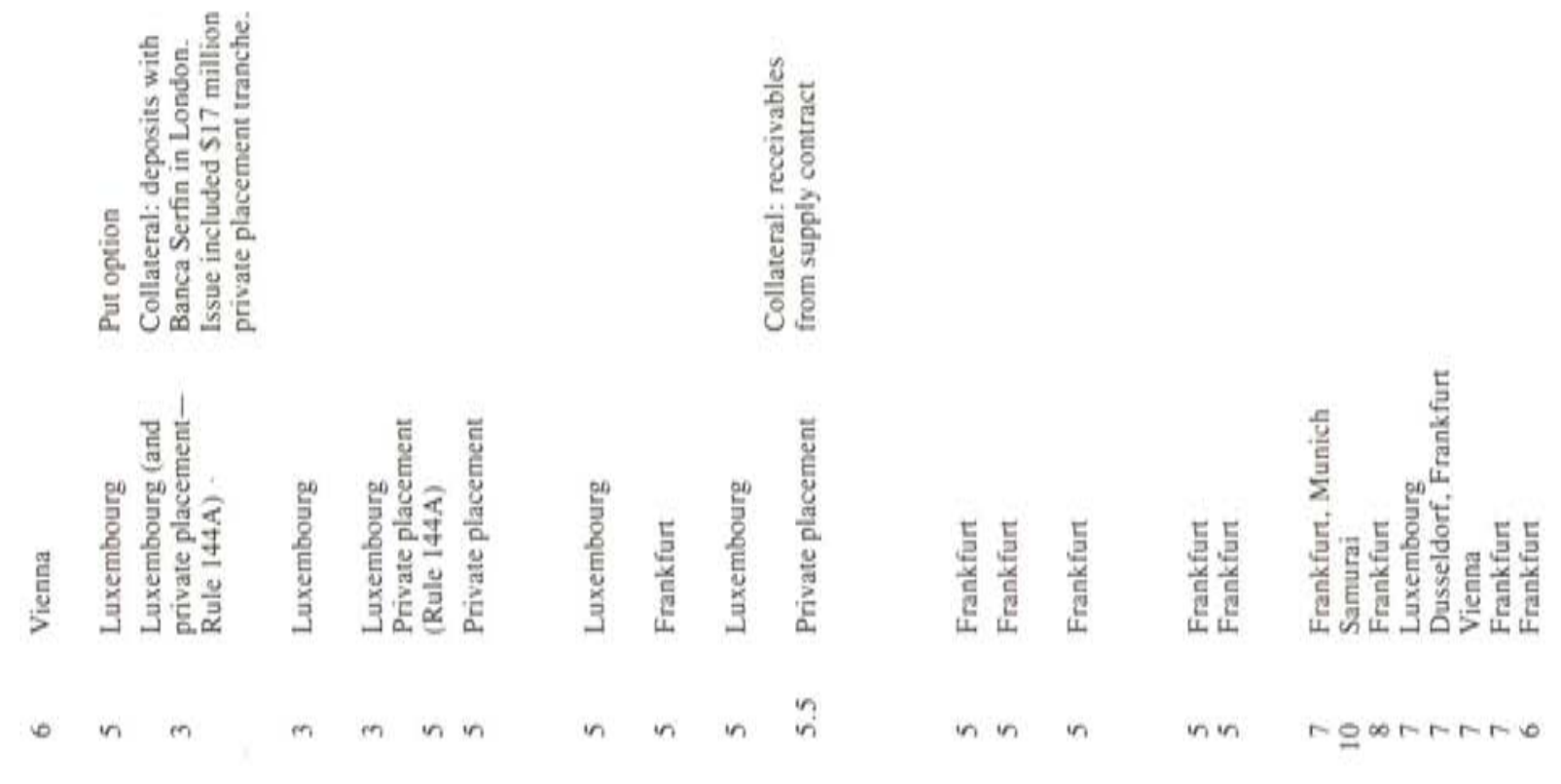

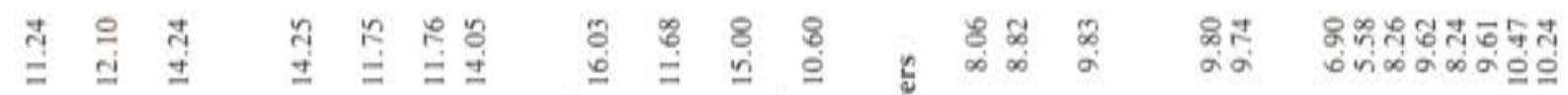

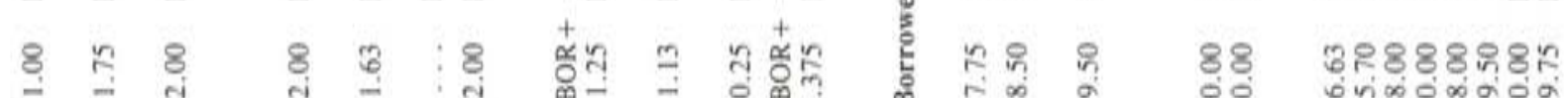

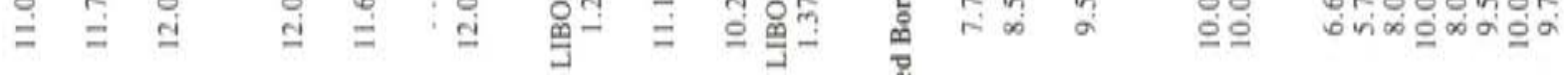

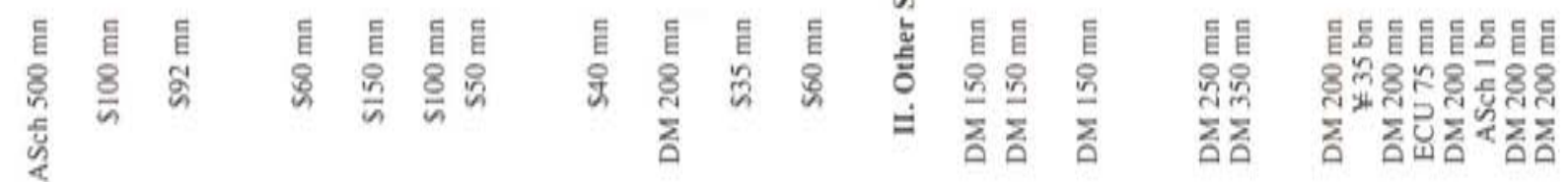

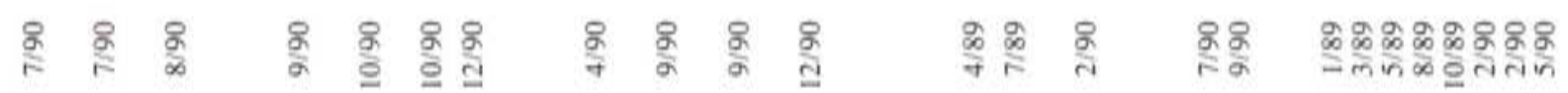

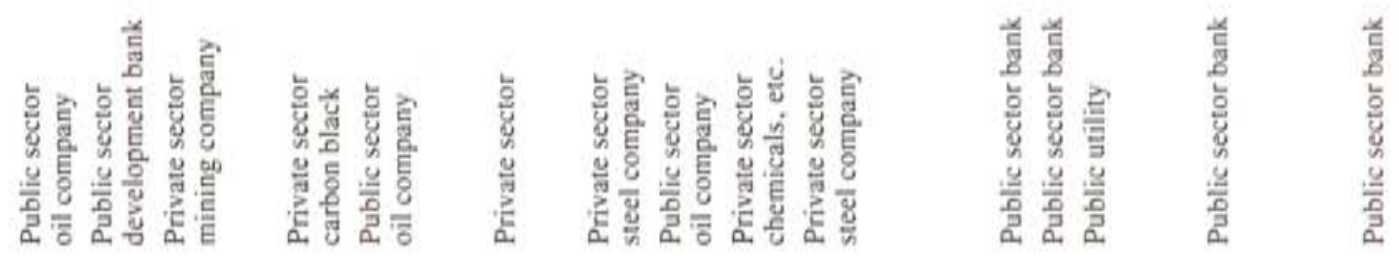

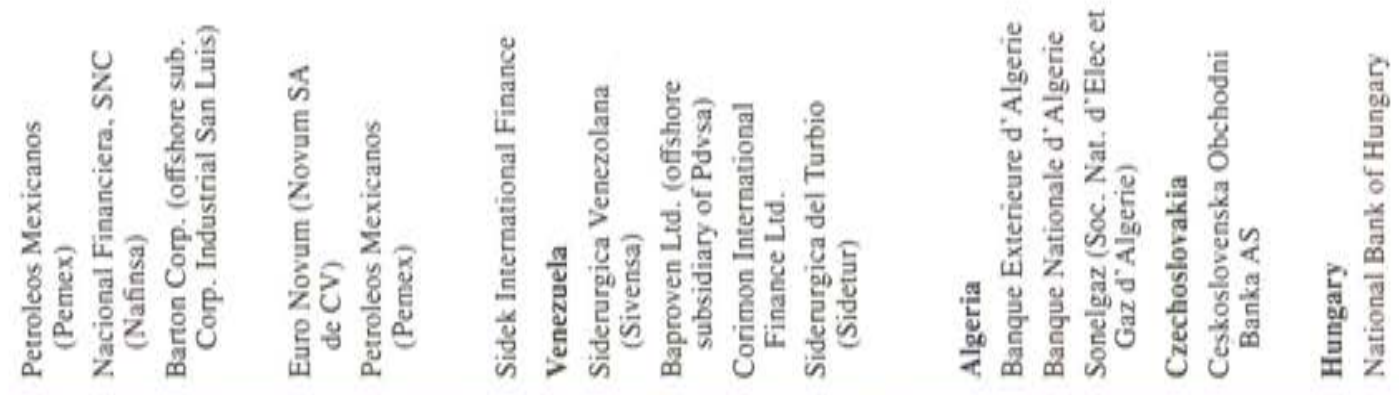




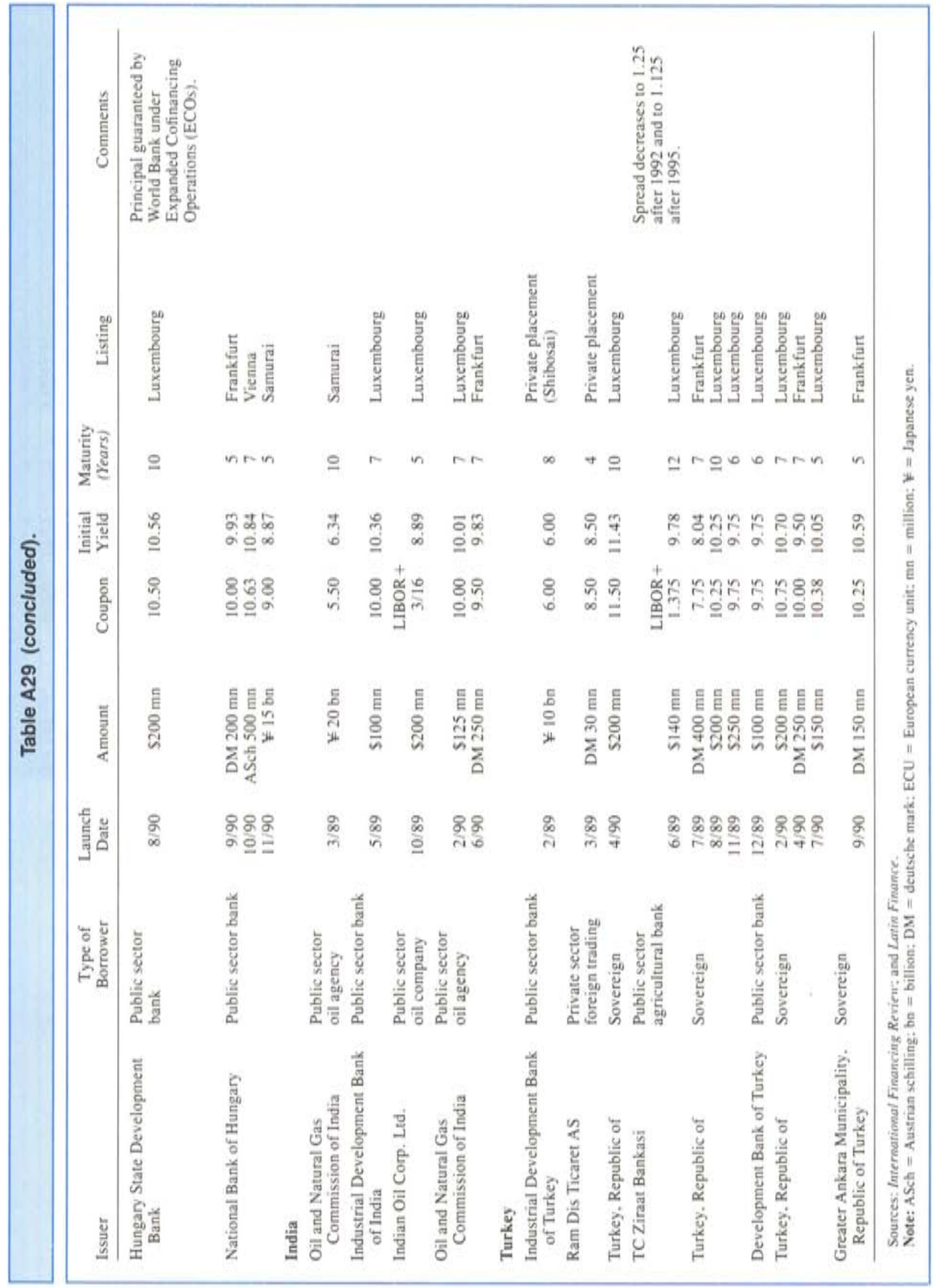


Table A30. Amounts of Medium- and Long-Term Bank Debt Restructured, 1984-901 (In millions of U.S. dollars; classified by year of agreement in principle)

\begin{tabular}{|c|c|c|c|c|c|c|c|}
\hline & 1984 & 1985 & 1986 & 1987 & 1988 & 1989 & 1990 \\
\hline Argentina & 14,200 & - & - & $29.500^{2}$ & - & - & - \\
\hline Bolivia & - & - & - & - & $\overline{-}$ & - & - \\
\hline Brazil & 4,846 & - & $6,671^{3}$ & - & $61,000^{4}$ & - & - \\
\hline Chile & 1,160 & 6,007 & - & $5,902^{4}$ & -5 & - & $1,800^{6}$ \\
\hline Congo & - & - & 217 & - & - & - & - \\
\hline Costa Rica & - & 440 & - & - & - & $1,825^{7}$ & - \\
\hline Côte d'Ivoire & 501 & - & $691^{4}$ & - & $2,211^{4}$ & - & - \\
\hline Dominican Republic & - & $787^{4}$ & - & $\overrightarrow{-}$ & - & - & - \\
\hline Ecuador & $4,260^{4}$ & - & - & $4,683^{4}$ & - & - & - \\
\hline Gabon & - & - & - & 39 & - & - & - \\
\hline Gambia, The & - & - & - & 19 & - & - & - \\
\hline Guinea & - & - & - & 43 & - & - & - \\
\hline Guyana & $(35)^{8}$ & $(47)^{8}$ & $(57)^{8}$ & - & - & - & - \\
\hline Honduras & $\overline{-}$ & - & - & $248^{4}$ & - & $132^{2}$ & - \\
\hline Jamaica & 165 & 195 & - & $285^{4}$ & - & - & 332 \\
\hline Jordan & $\bar{c}$ & - & - & - & - & $580^{4}$ & - \\
\hline Madagascar & 195 & $\ldots{ }^{5}$ & - & $\ldots 5$ & - & - & 21 \\
\hline Malawi & - & - & - & - & $35^{2}$ & - & - \\
\hline Mexico & $48,700^{4}$ & $(950)^{8}$ & $43,700^{4}$ & - & $3.671^{7}$ & $48,089^{7}$ & $\overline{-}$ \\
\hline Morocco & - & 538 & 2,174 & - & - & - & 3,150 \\
\hline Mozambique & - & - & - & $253^{2}$ & - & - & - \\
\hline Nicaragua & $(145)^{8}$ & - & - & - & - & - & - \\
\hline Niger & 27 & - & 52 & - & - & - & - \\
\hline Nigeria & - & $\overline{0}$ & 4,250 & - & $5,824^{2}$ & - & - \\
\hline Panama & - & 579 & - & - & - & - & - \\
\hline Peru & 460 & - & - & - & - & - & - \\
\hline Philippines & 5,885 & - & - & $9,010^{4}$ & - & 781 & - \\
\hline Poland & 1,390 & - & 1,970 & $8,441^{4}$ & - & $(351)^{8}$ & - \\
\hline Romania & - & - & 800 & -9 & - & - & - \\
\hline Senegal & 78 & 20 & - & - & - & - & 37 \\
\hline Sierra Leone & 25 & - & - & $\overline{-}$ & - & - & - \\
\hline South Africa & - & - & $(9,800)^{8}$ & $10,900^{4}$ & - & - & - \\
\hline Sudan & 838 & 920 & - & - & - & - & - \\
\hline Togo & - & - & - & - & $49^{2}$ & - & - \\
\hline Trinidad and Tobago & - & - & - & - & $470^{4}$ & - & - \\
\hline Uruguay & $(104)^{8}$ & $1,958^{2}$ & - & $1,770^{4}$ & - & - & $1,604^{10}$ \\
\hline Venezuela & $21,088^{4}$ & - & - & $20,338^{4}$ & - & - & $19,786^{10}$ \\
\hline Yugoslavia & 1,250 & $4,012^{4}$ & - & - & $6,895^{2}$ & - & - \\
\hline Zaïre & $(64)^{8}$ & $(61)^{8}$ & $(65)^{8}$ & $(61)^{8}$ & - & $(61)^{8}$ & - \\
\hline Zambia & 74 & - & - & - & - & - & - \\
\hline Total 11 & 105,142 & 15,456 & 60,525 & 91,431 & 80,155 & 51,552 & 26,730 \\
\hline \multicolumn{8}{|c|}{ 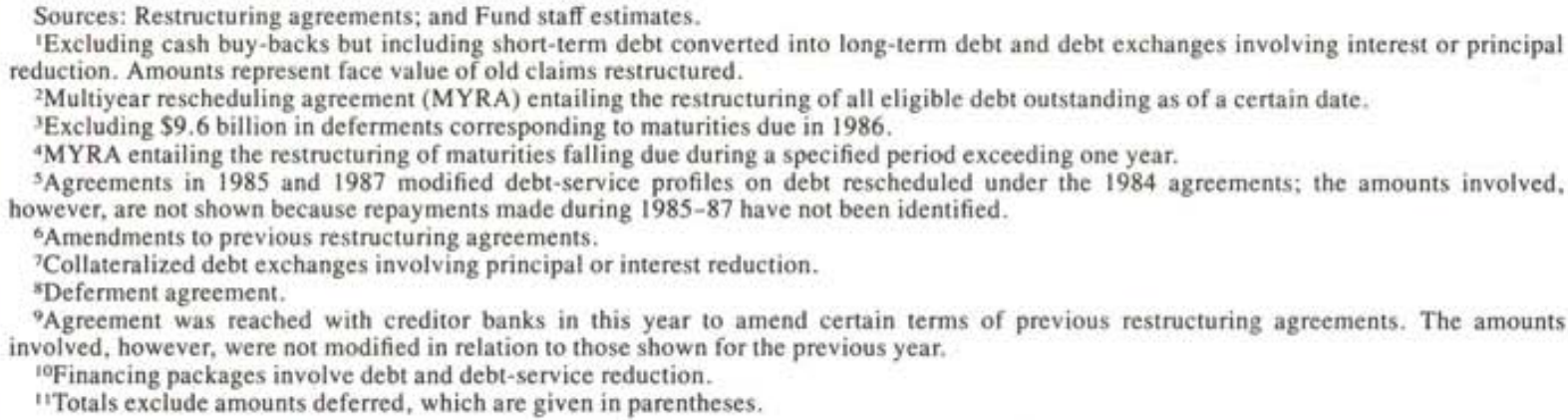 } \\
\hline
\end{tabular}




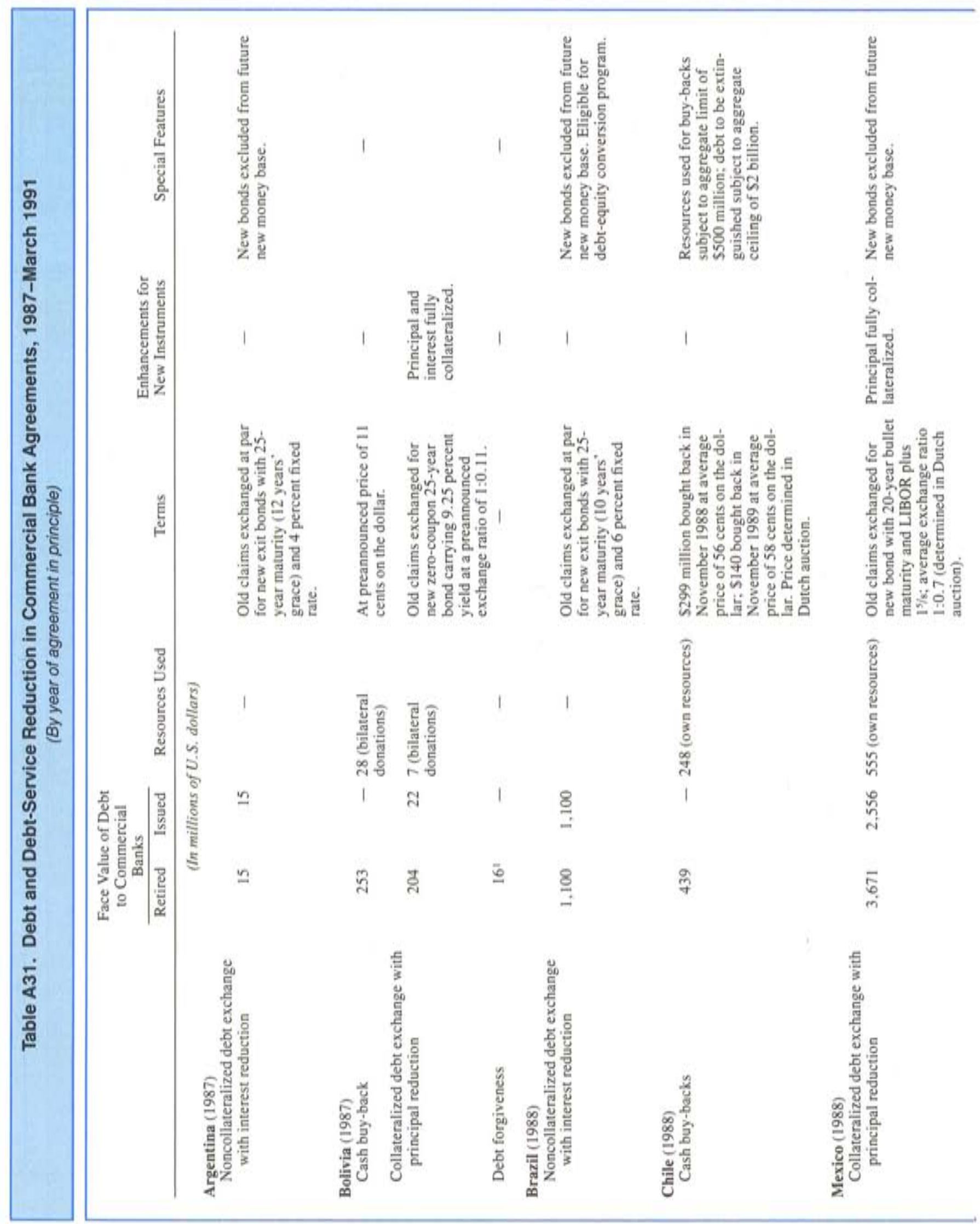



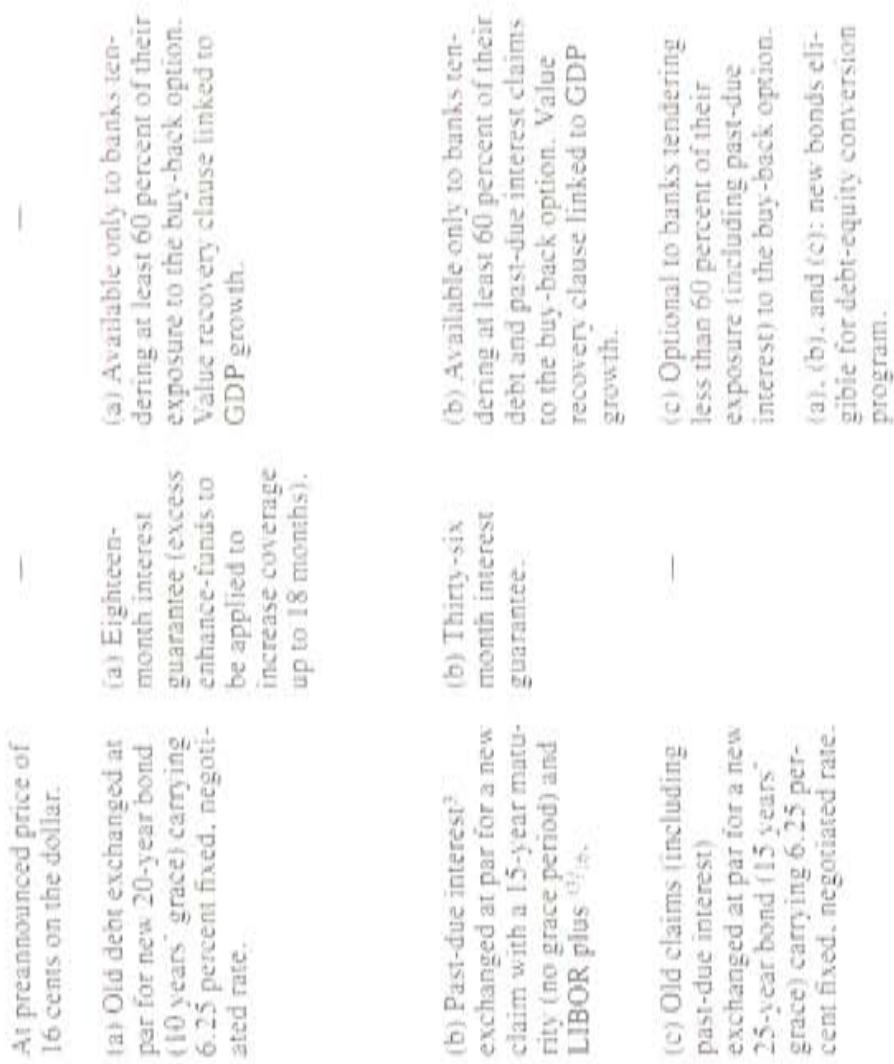
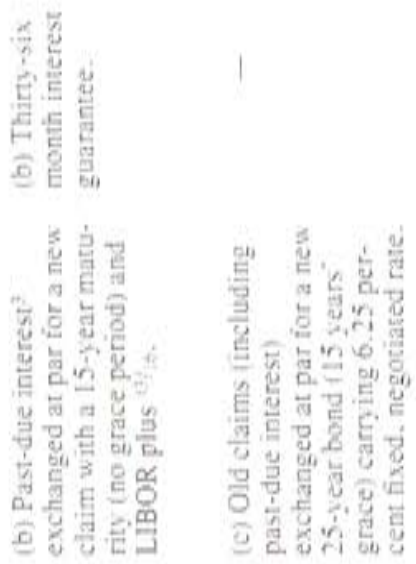

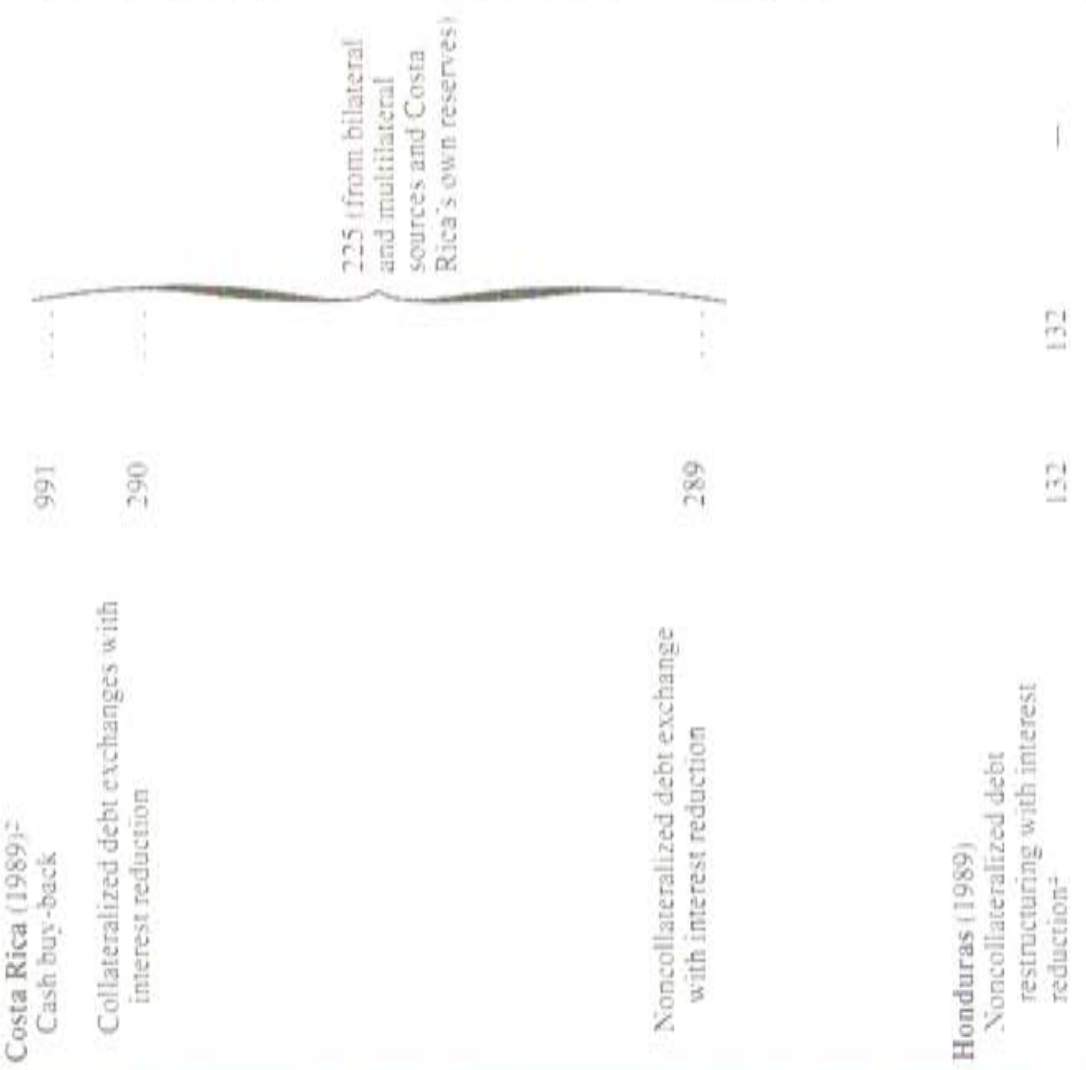

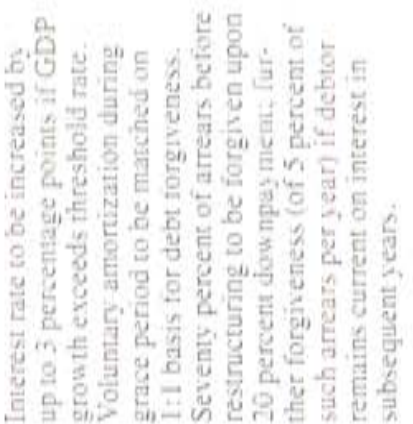

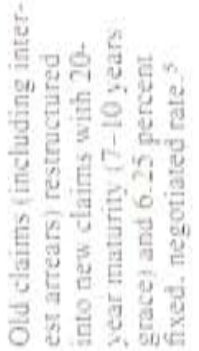




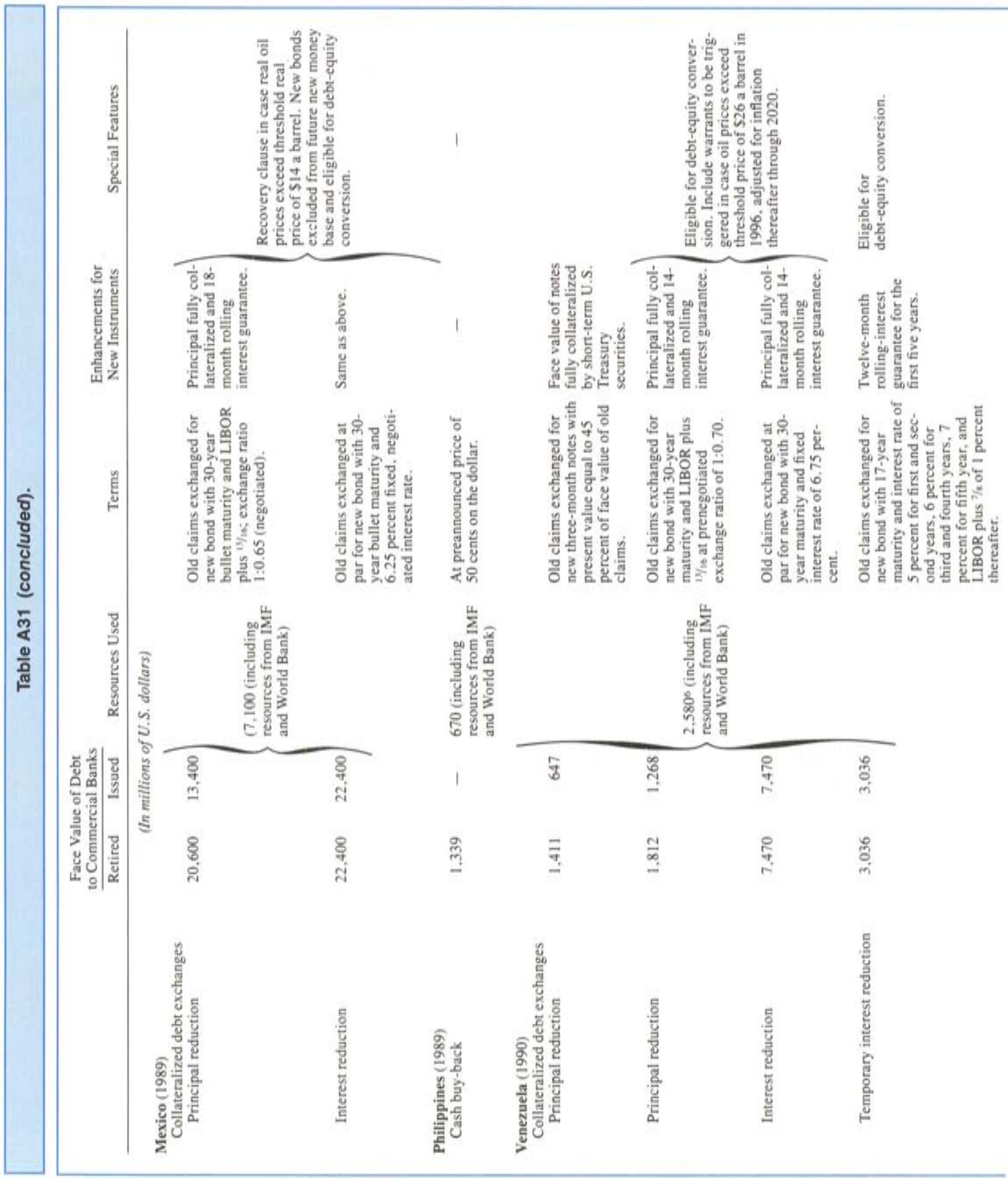




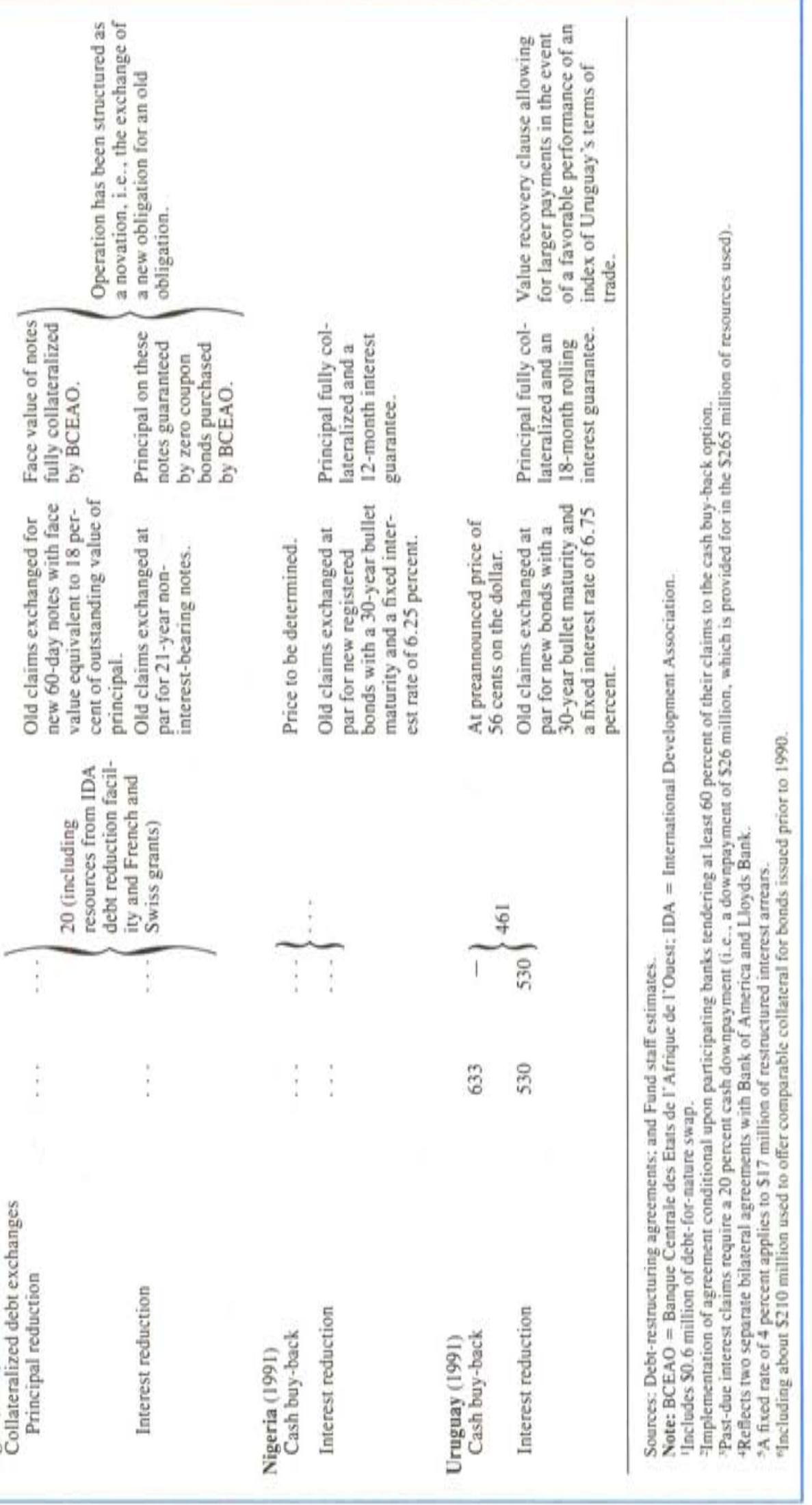


Table A32. Terms of Selected Bank Debt Restructurings and Financial Packages, 1984-901

\begin{tabular}{|c|c|c|c|c|c|c|}
\hline Country & $\begin{array}{c}\text { Year of } \\
\text { Agreement }\end{array}$ & $\begin{array}{c}\text { Type of } \\
\text { Transaction }\end{array}$ & Grace Period & Maturity & Interest Rate & Fees \\
\hline & & & (In yea & & $\begin{array}{c}\text { (In percent spread } \\
\text { over LIBOR/U.S. Prime) }\end{array}$ & $\begin{array}{c}(\text { In } \\
\text { percent })\end{array}$ \\
\hline \multirow[t]{6}{*}{ Argentina } & \multirow[t]{2}{*}{1984} & \multirow{2}{*}{$\begin{array}{l}\text { Restructuring } \\
\text { New financing }\end{array}$} & 3 & 10 to 12 & $1^{3 / 8}$ & - \\
\hline & & & 3 & 10 & $15 / 8-11 / 4$ & $5 / 8$ \\
\hline & \multirow{4}{*}{1987} & New financing & 5 & 12 & $7 / 8$ & $3 / 8^{2}$ \\
\hline & & New financing ${ }^{3}$ & - & 4 & $7 / 8$ & $3 / 8^{2}$ \\
\hline & & Restructuring ${ }^{4.5}$ & 7 & 19 & $13 / 16$ & - \\
\hline & & Restructuring ${ }^{4.5}$ & 5 & 12 & $13 / 16$ & - \\
\hline \multirow[t]{6}{*}{ Brazil } & \multirow[t]{2}{*}{1984} & Restructuring & 5 & 9 & $2-13 / 4$ & 1 \\
\hline & & New financing & 5 & 9 & $2-13 / 4$ & 1 \\
\hline & \multirow{4}{*}{$\begin{array}{l}1986 \\
1988\end{array}$} & Restructuring & 5 & 7 & $1^{1 / 3}$ & - \\
\hline & & Restructuring 5 & 7 & 19 & $13 / 16$ & - \\
\hline & & New financing ${ }^{6}$ & 5 & 12 & $13 / 16$ & $3 / 8^{2}$ \\
\hline & & New financing ${ }^{3}$ & 9 & 9 & $13 / 16$ & $3 / 8^{2}$ \\
\hline \multirow[t]{8}{*}{ Chile } & \multirow{3}{*}{$\begin{array}{l}1984 \\
1985\end{array}$} & New financing & 5 & 9 & $13 / 4-11 / 2$ & $5 / 8$ \\
\hline & & Restructuring & 6 & 12 & $1^{3 / 8}$ & $1 / 8$ \\
\hline & & New financing & 5 & 10 & $15 / 8-11 / 4$ & $1 / 2$ \\
\hline & \multirow[t]{2}{*}{1987} & Restructuring 4.5 & 3 & 5 & $11 / \mathrm{s}$ & - \\
\hline & & Restructuring 5 & 5 & $15^{1 / 2}$ & 1 & - \\
\hline & \multirow[t]{2}{*}{1988} & Restructuring 4.5 & 5 & 15 & $13 / 16$ & - \\
\hline & & Restructuring ${ }^{3 / 4}$ & 3 & 5 & $7 / 8$ & - \\
\hline & 1990 & Restructuring & 4 & 8 to 12 & Original rates & - \\
\hline \multirow{6}{*}{ Côte d'Ivoire } & \multirow[t]{3}{*}{1984} & Restructuring & 2 & 7 & $1^{7 / 8}-1^{5 / 8}$ & $1 \%$ \\
\hline & & Restructuring & 3 & 8 & $17 / 8-15 / 8$ & $11 / 4$ \\
\hline & & New financing & 3 & 7 & $1^{7} / 8-15 / 8$ & $11 / 4$ \\
\hline & \multirow{3}{*}{$\begin{array}{l}1986 \\
1988\end{array}$} & Restructurings & 3 & 9 & $1^{5 / 8-13 / 8}$ & - \\
\hline & & Restructuring 5 & 5 & $14 \frac{1}{2}$ & $11 / 4$ & $1 / 2^{2}$ \\
\hline & & New financing & 4 & 8 & $11 / 2$ & $3 / 4^{2}$ \\
\hline Dominican Republic & 1985 & Restructuring 5 & 3 & 13 & $13 / 8$ & - \\
\hline \multirow{5}{*}{ Ecuador } & \multirow{2}{*}{1985} & Restructuring 5 & 3 & 12 & $13 / 8$ & - \\
\hline & & New financing & 2 & 10 & $15 / 8-11 / 4$ & - \\
\hline & \multirow[t]{3}{*}{1987} & Restructuring? & 3 & 10 & 1 & \\
\hline & & Restructuring ${ }^{8}$ & 7 & 19 & $15 / 16$ & \\
\hline & & New financing & 2 & 8 & 1 & $1 / 2-1 / 8^{2}$ \\
\hline \multirow[t]{4}{*}{ Jamaica } & 1987 & Rescheduling & $11 / 2$ & $81 / 2$ & $1 \frac{1 / 4}{4}$ & - \\
\hline & & Rescheduling & 9 & $12 \frac{1 / 2}{2}$ & $11 / 4$ & - \\
\hline & 1990 & Refinancing & - & $10^{1 / 2}$ & $13 / 16$ & - \\
\hline & & Refinancing & $71 / 2$ & $14^{1 / 2}$ & $13 / 16$ & - \\
\hline Mexico & 1984 & New financing & $5^{1 / 2}$ & 10 & $11 / 2-11 / 8$ & $5 / 8$ \\
\hline & & Restructuring 5 & 0 to 1 & 14 & $7 / 8$ in $1985-86$ & - \\
\hline & & & & & $1 \frac{1}{x}$ in $1987-91$ & - \\
\hline & & & & & $11 / 4$ in $1992-98$ & - \\
\hline & 1986 & Restructuring 5 & 7 & 20 & $13 / 16$ & - \\
\hline & & New financing & 5 & 12 & $13 / 16$ & - \\
\hline & & New financing ${ }^{9}$ & 7 & 12 & $13 / 16$ & - \\
\hline & & New financing ${ }^{10}$ & 4 & 8 & $13 / 16$ & - \\
\hline & 1989 & New financing & 7 & 15 & $13 / 16$ & - \\
\hline & & Restructuring & 7 & 15 & $13 / 16$ & - \\
\hline Morocco & 1986 & Restructuring & 3 & 7 & $13 / 4$ & - \\
\hline & 1987 & $\begin{array}{l}\text { Restructuring } \\
- \text { Not previously }\end{array}$ & & & & \\
\hline & & $\begin{array}{l}\text { rescheduled } \\
\text { - Previously }\end{array}$ & 4 & 11 & $13 / 16$ & - \\
\hline & & rescheduled & 4 & 4 & $13 / 4$ & - \\
\hline & & $\begin{array}{l}\text {-Conversion short- } \\
\text { term in medium- }\end{array}$ & & & & \\
\hline & & term & - & 6 & $13 / 16$ & - \\
\hline & & - Trade arrears & - & $51 / 2$ & Original rates & - \\
\hline & 1990 & Restructuring & $7-10$ & $15-20$ & $13 / 16$ & - \\
\hline
\end{tabular}


Table A32 (concluded).

\begin{tabular}{|c|c|c|c|c|c|c|}
\hline Country & $\begin{array}{c}\text { Year of } \\
\text { Agreement }\end{array}$ & $\begin{array}{c}\text { Type of } \\
\text { Transaction }\end{array}$ & Grace Period & Maturity & Interest Rate & Fees \\
\hline & & & (In yea & & $\begin{array}{c}\text { (In percent spread } \\
\text { over LIBOR/U.S. Prime) }\end{array}$ & $\begin{array}{c}(\text { In } \\
\text { percent })\end{array}$ \\
\hline \multirow[t]{6}{*}{ Nigeria } & 1986 & Restructuring 11 & 1 & 4 & $1 \frac{1}{4}$ & $1 / 2$ \\
\hline & & Restructuring 12 & 3 & 9 & $11 / 4$ & $1 / 2$ \\
\hline & & New financing & 3 & 7 & $15 / 16$ & $1 / 2$ \\
\hline & 1988 & Restructuring ${ }^{13}$ & 3 & 20 & $7 / 8$ & $1 / 214$ \\
\hline & & Restructuring ${ }^{15}$ & 3 & 15 & $13 / 16$ & - \\
\hline & 1990 & Restructuring 16 & - & 3 & none 17 & - \\
\hline \multirow[t]{4}{*}{ Philippines } & 1984 & Restructuring & 5 & 10 & $15 / 8$ & - \\
\hline & & New financing & 5 & 9 & $1^{3 / 4-13 / 8}$ & $1 / 2$ \\
\hline & 1987 & Restructuring 5 & $71 / 2$ & 17 & $7 / 8$ & - \\
\hline & & Restructuring 5.18 & 6 & 10 & $13 / 8$ & - \\
\hline Poland & 1988 & Restructuring & 8 & 15 & $13 / 16$ & - \\
\hline \multirow[t]{5}{*}{ Uruguay } & 1986 & Restructurings & 3 & 12 & $13 / 8$ & - \\
\hline & & Restructuring 4,5 & 3 & 12 & $15 / 8$ & - \\
\hline & 1987 & Restructuring 4.5 & 3 & 17 & $7 / 8$ & - \\
\hline & 1990 & New financing & 7 & 15 & 1 & $1 / 8^{2}$ \\
\hline & & Restructuring & 7 & 15 & $7 / 8$ & $1 / 8^{2}$ \\
\hline \multirow[t]{4}{*}{ Venezuela } & 1984 & Restructuring 5 & - & $12^{1 / 2}$ & $11 / 8$ & - \\
\hline & 1987 & Restructuring ${ }^{4}$ & - & 13 & $7 / 8$ & - \\
\hline & 1990 & New financing & 7 & 15 & $7 / 8-1$ & $1 / 2^{2}$ \\
\hline & & Restructuring & 7 & 15 & $17 / 8$ & - \\
\hline \multirow[t]{4}{*}{ Yugoslavia } & 1984 & Restructuring & 4 & 7 & $15 / 8-1 \frac{1}{2}$ & $7 / 8$ \\
\hline & 1985 & Restructuring 5 & 4 & $10^{1 / 2}$ & $1^{1 / s}$ & - \\
\hline & 1988 & Restructuring 5 & 5 & 18 & $13 / 16$ & - \\
\hline & & New financing & 5 & 5 & $7 / x$ & $1 / 4^{2}$ \\
\hline \multicolumn{7}{|c|}{ 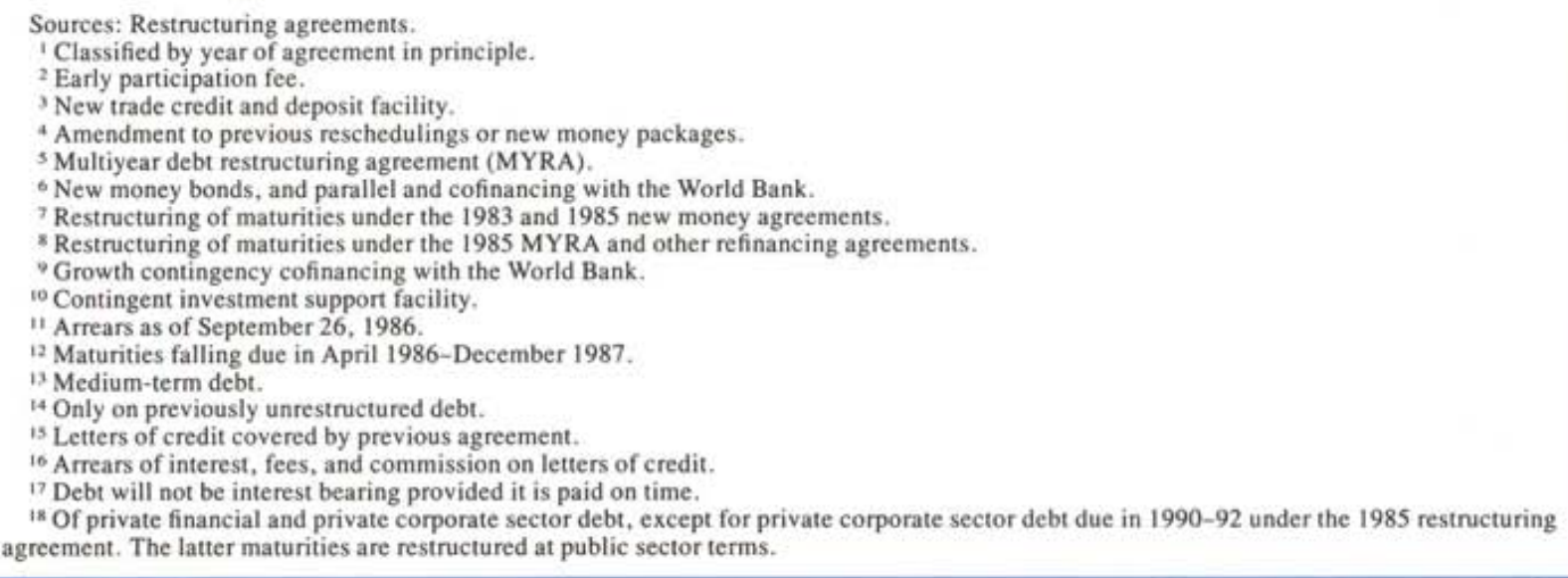 } \\
\hline
\end{tabular}


Table A33. Terms and Conditions of Bank Debt Restructurings and Financial Packages, 1989-March 19911

\begin{tabular}{|c|c|c|c|c|c|}
\hline $\begin{array}{l}\text { Country, Date of Agreement, } \\
\text { and Type of Debt Rescheduled }\end{array}$ & Basis & $\begin{array}{l}\text { Amount } \\
\text { Provided }\end{array}$ & $\begin{array}{l}\text { Grace } \\
\text { Period }\end{array}$ & Maturity & Interest Rate \\
\hline & & $\begin{array}{l}\text { (In millions } \\
\text { of U.S. } \\
\text { dollars) }\end{array}$ & $\begin{array}{l}\text { (In ye: } \\
\text { otherv }\end{array}$ & $\begin{array}{l}\text { unless } \\
\text { noted) }\end{array}$ & $\begin{array}{l}\text { (In percent } \\
\text { spread over } \\
\text { LIBOR/U.S. } \\
\text { prime, unless } \\
\text { otherwise noted) }\end{array}$ \\
\hline \multicolumn{6}{|l|}{ Chile } \\
\hline \multicolumn{6}{|l|}{$\begin{array}{l}\text { Agreement in principle of } \\
\text { October 1990; final agree- } \\
\text { ment of December } 1990\end{array}$} \\
\hline \multirow[t]{2}{*}{$\begin{array}{l}\text { Amendments to the restruc- } \\
\text { turing agreements of } \\
\text { June } 17,1987 \text {, already } \\
\text { amended in August } 1988\end{array}$} & $\begin{array}{l}\text { 1983- } 84 \text { restructuring agree- } \\
\text { ments, } 1985-87 \text { restructuring } \\
\text { agreements, } 1988-91 \text { restruc- } \\
\text { turing agreements, } 1983-85 \\
\text { new money agreements }\end{array}$ & & & & \\
\hline & Unchanged & 1,800 & 4 & $8-12$ & Unchanged ${ }^{2}$ \\
\hline \multicolumn{6}{|l|}{ Costa Rica } \\
\hline \multicolumn{6}{|l|}{$\begin{array}{l}\text { Preliminary agreement of } \\
\text { November } 16,1989\end{array}$} \\
\hline \multicolumn{6}{|l|}{ Honduras } \\
\hline \multicolumn{6}{|l|}{ Agreements of August 17, 1989} \\
\hline \multicolumn{6}{|l|}{$\begin{array}{l}\text { Bilateral concessional } \\
\text { rescheduling of debt to } \\
\text { Lloyds Bank }\end{array}$} \\
\hline $\begin{array}{l}\text { Principal outstanding at end } \\
\text { of October } 1989\end{array}$ & 100 percent & $46^{3}$ & 7 & 20 & $\begin{array}{l}6.25 \text { percent } \\
\text { fixed rate }\end{array}$ \\
\hline $\begin{array}{l}\text { Interest arrears at end of } \\
\text { October } 1989\end{array}$ & 100 percent & $22^{3} 5$ & 7 & 20 & $\begin{array}{l}6.25 \text { percent } \\
\text { fixed rate }\end{array}$ \\
\hline $\begin{array}{l}\text { Bilateral concessional } \\
\text { rescheduling of debt to }\end{array}$ & & & & & \\
\hline $\begin{array}{l}\text { Principal outstanding } \\
\text { Interest arrears as of end of }\end{array}$ & 100 percent & $47^{3}$ & 10 & 20 & 6.5 percent \\
\hline $\begin{array}{l}\text { Interest arrears as of end of } \\
\text { October } 1989\end{array}$ & 100 percent & $17^{5}$ & $2 / 3$ & 20 & $\begin{array}{l}4 \text { percent fixed } \\
\text { rate }\end{array}$ \\
\hline \multicolumn{6}{|l|}{ Jamaica } \\
\hline \multicolumn{6}{|l|}{$\begin{array}{l}\text { Refinancing of debt previ- } \\
\text { ously rescheduled in } 1987\end{array}$} \\
\hline Tranche A & 100 percent of principal & 144 & - & $101 / 2$ & $13 / 16$ \\
\hline Tranche B & 100 percent of principal & 188 & 8 & $14 \frac{1}{2}$ & $3 / 16$ \\
\hline \multicolumn{6}{|l|}{ Jordan } \\
\hline \multicolumn{6}{|l|}{$\begin{array}{l}\text { Agreement in principle of } \\
\text { November } 20,1989\end{array}$} \\
\hline \multicolumn{6}{|l|}{$\begin{array}{l}\text { Restructuring of medium- } \\
\text { term loans maturing } \\
\text { between January } 1 \text {, }\end{array}$} \\
\hline facility & New money & 50 & 3 & 3 & $13 / 16$ \\
\hline
\end{tabular}


Table A33 (continued).

Country, Date of Agreement, and Type of Debt Rescheduled

\section{Madagascar}

Agreement in principle in October 1989 and signed on April 10, 1990

Rescheduling

Mexico

Agreement of February 4, 1990

New money facility

Collateralized debt exchanges

Restructuring of maturities of eligible debt not subject to debt and debt-service reduction

100 percent of principal

100 percent of principal falling due on December 15, 1989 and 50 percent of principal falling due in 1990-93

New money ${ }^{6}$

Debt reduction (see Table A31)

of U.S.
dollars)

(In years, unless otherwise noted)

Amount Grace

Provided Period Maturity Interest Rate

(In percent

spread over

LIBOR/U.S.

prime, unless

otherwise noted)

\section{Morocce}

Agreement in principle of April 1990; final agreement of September $1990^{7}$

Restructuring of the entire debt outstanding at end of 1989

Debt buy-backs authorized

100 percent of pre cut-off debt

3,150

\section{Niger}

Agreement in principle of January 1991 collateralized debt exchanges

Debt reduction (see Table A31)

\section{Nigeria}

Agreement in principle of September 1988; final agreement of April 1989

Restructuring of debt outstanding at end of 1987

Not previously rescheduled medium-term debt

Debt covered by the November 1987 rescheduling agreement

Debt (letters of credit) covered by the November 1987 refinancing agreement

100 percent of principal

100 percent of principal

Arrears on interest, fees, and commissions on letters of credit 100 percent

Agreement in principle of March 1991

New money bond exchange Banks would provide new money for an amount equivalent to 10 percent of debts exchanged for noncol-

lateralized new bonds.

Buy-back and debt exchange

$\begin{array}{cccc}1,256 & 3 & 20 & 7 / 8 \\ 1,635 & 3 & 20 & 7 / 8 \\ \begin{array}{c}2,448 \\ 490^{8}\end{array} & - & 15 & \begin{array}{c}13 / 16 \\ \text { non-interest- } \\ \text { bearing }\end{array} \\ \ldots & 7 & 15 & 1\end{array}$




\section{Table A33 (continued).}

\section{Country, Date of Agreement, and Type of Debt Rescheduled}

\section{Philippines}

Agreement in principle of

October 1989; final agree-

ment of February 1990:

New money bonds or loans

Rescheduling of maturities falling due in 1990-93

Change in spread on previously restructured debt

Waivers to allow debt buybacks and exchanges

Poland

Agreement in principle of June 16, 1989

Deferment of amortization payments falling due between May 1989 December $1990^{\prime \prime}$

Agreement in principle of October 1989

Rescheduling of interest falling due in the fourth quarter of 198912

New money

100 percent of principal

Debt reduction (see Table A31)
Amount Provided

\section{Grace}

Period
Interest Rate

(In percent

spread over

(In millions

of U.S.

(In years, unless

LIBOR/U.S.

prime, unless

dollars)

otherwise noted)

\section{Senegal}

Agreement of September 1990

Trinidad and Tobago

Agreement in principle of

November 1988; final

agreement December 1989

Medium- and long-term

maturities falling due Sep-

tember 1, 1988 -

August 31, 1992

100 percent of principal

446

$41 / 2$

$12^{1 / 2}$

$15 / 16$

\section{Uruguay}

Agreement in principle of November 1990: final agreement January 1991 New Money Bond Exchange

Buy-back and debt exchange

20 percent increase in exposure via purchase of new bonds would entitle banks to exchange at par old debt for noncollateralized "debt conversion notes"

Debt reduction (see Table A31)
89

7

15

1.0 
Table A33 (concluded).

Country, Date of Agreement, and Type of Debt Rescheduled

Basis

$\begin{array}{cc}\begin{array}{c}\text { Amount } \\ \text { Provided }\end{array} & \begin{array}{l}\text { Grace } \\ \text { Period }\end{array}\end{array}$

Maturity
Interest Rate

(In percent

spread over

LIBOR/U.S.

prime, unless

otherwise noted)

\section{Venezuela}

In millions

of U.S.

(In years, unless

Agreement in principle of

March 20, 1990; final term

sheet of June 25, 1990; final

agreement of December 5 ,

1990

New Money Bond Exchange

Old debt (equal to five times the new money provided) to be exchanged at par for new, noncollateralized bonds. otherwise noted

Debt reduction (see Table A31)

Zaïre

Collateralized debt exchanges

Deferment agreement of June $1989^{14}$

Sources: Restructuring agreements; and Fund staff estimates.

' Arrangements approved in principle before January 1. 1989 were reported in previous issues of International Capital Markets: Develop. ments and Prospects, World Economic and Financial Surveys (Washington: International Monetary Fund).

${ }^{2}$ The amendments provide for an extension of the retiming periods during which annual interest periods, which had been scheduled to revert to six-month interest periods, will be maintained. The extension will be until 1993 for 1985 new money; until 1994 for 1983 and 1984 new money; until 1995 for the 1983-84 restructuring agreements; and until 1996 for the 1985-91 restructuring agreements.

'Voluntary amortization payments made during the grace period would be matched on a 1 : I basis by debt forgiveness (equivalent to a buyback option at 50 cents on the dollar).

4 Interest rate would be increased by a maximum of 3 percentage points if GDP growth exceeds a threshold rate.

s Seventy percent of these arrears to be forgiven in 1990 upon downpayment equal to 5 percent of these arrears. Beginning at the end of 1990 and provided that Honduras remains current on interest due on all rescheduled amounts under the agreement, the creditor bank would further forgive interest arrears by a yearly amount equal to 5 percent of the arrears outstanding at the end of October 1989.

6 New money options include medium-term loan, new money bonds, on-lending facility, and medium-term trade facility.

7 Entry into force of the first stage of the agreement was scheduled on July 1990 subject to the negotiation of an adjustment program with the IMF. Entry into force of the second stage of the agreement (which envisages interest rate reductions for six to eight years) is contingent upon the approval by the IMF of an extended arrangement.

8 Includes $\$ 112$ million of previously capitalized interest arrears on letters of credit.

Allowance for re-lending for up to 366 days of up to 20 percent of the new money on a revolving basis, of which one half would be available in any one calendar year and one half would be available to the private sector.

10 As of the end of December 1989.

"Payment is to be deferred until December 30. 1991. Alternatively, banks may receive payments according to the original schedule in return for an equal increase in the short-term revolving trade facility.

12 Payment was deferred until the second quarter of 1990.

${ }_{13}$ The interest rate of LIBOR plus \% applies to the new money bonds issued by the Central Bank (as opposed to the Republic of Venezuela).

14 Under this agreement Zaïre would make monthly payments of \$4 million, which roughly covers interest on outstanding claims (including principal and interest arrears). 


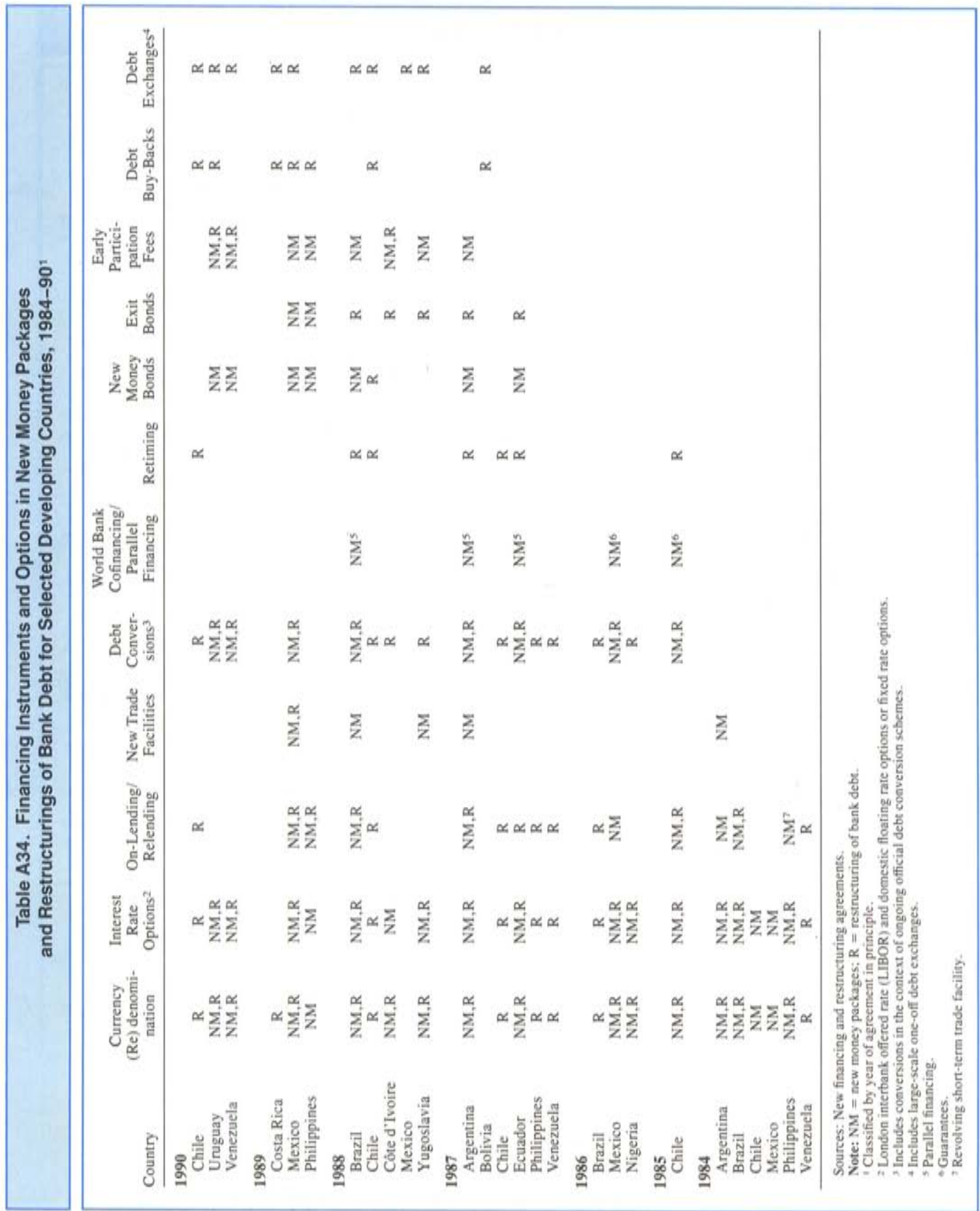


Table A35. Features of Selected Debt Conversion Schemes

\begin{tabular}{|c|c|c|c|c|c|c|c|c|c|c|c|c|}
\hline & Argentina & Brazil! & Chile & $\begin{array}{l}\text { Costa } \\
\text { Rica }\end{array}$ & Ecuador ${ }^{2}$ & Honduras & Jamaica & Mexico & Nigeria & $\begin{array}{l}\text { Philip- } \\
\text { pines }\end{array}$ & Uruguay & $\begin{array}{l}\text { Vene- } \\
\text { zuela }\end{array}$ \\
\hline \multicolumn{13}{|l|}{ Eligible investors } \\
\hline $\begin{array}{l}\text { Nonresidents } \\
\text { Any creditor } \\
\text { Original creditor only }\end{array}$ & $\mathrm{x}$ & $\mathrm{x}$ & $\mathrm{x}$ & $\mathrm{x}$ & $\mathrm{x}$ & $\mathrm{x}$ & $\mathrm{x}$ & $\mathrm{x}$ & $\mathrm{x}$ & $\mathrm{x}$ & $\mathrm{x}$ & $\mathrm{x}$ \\
\hline Residents & $\mathrm{x}$ & & $\mathrm{x}$ & $\mathrm{x}$ & $\mathrm{x}$ & $\mathrm{x}$ & & $x$ & & $\mathrm{x}$ & $x$ & $\mathrm{x}$ \\
\hline \multicolumn{13}{|l|}{ Eligible external debt } \\
\hline Public sector & $\mathrm{x}$ & $\mathrm{x}$ & $\mathrm{x}$ & $\mathrm{x}$ & $x$ & $\mathrm{x}$ & $x^{3}$ & $x$ & $x^{4}$ & $x$ & $x$ & \\
\hline Private sector & $\mathrm{x}$ & $x$ & $\mathrm{x}$ & & & & & & & $\mathrm{x}$ & & $\mathrm{x}$ \\
\hline \multicolumn{13}{|l|}{ Exchange rate for conversion } \\
\hline $\begin{array}{l}\text { Official exchange rate } \\
\text { Parallel exchange rates }\end{array}$ & $x^{5}$ & $\mathrm{x}$ & $\mathrm{x}$ & $\mathrm{x}$ & $x$ & $\mathrm{x}$ & $\mathrm{x}$ & $\mathrm{x}$ & $\mathrm{x}$ & $\mathrm{x}$ & $x$ & $x^{5}$ \\
\hline \multicolumn{13}{|l|}{$\begin{array}{l}\text { Valuation of debs for } \\
\text { conversion }\end{array}$} \\
\hline Face value & & $x^{6}$ & & & $\mathrm{x}$ & $\mathrm{x}^{7}$ & $\mathrm{x}$ & & $x^{n}$ & & & \\
\hline Below face value & $\mathrm{x}$ & $\mathrm{x}$ & $x^{4}$ & $\mathrm{x}$ & & $x^{7}$ & & $x^{10 i}$ & $x^{\prime \prime}$ & $\mathrm{x}$ & $\mathrm{x}$ & $x$ \\
\hline \multicolumn{13}{|c|}{$\begin{array}{l}\text { Eligible domestic investments } \\
\text { Equity }\end{array}$} \\
\hline Parastatal enterprises & & $x$ & $x$ & & & $\mathrm{x}$ & $\mathrm{x}$ & $\mathrm{x}$ & & $x$ & & $\mathrm{x}$ \\
\hline Private companies & $x$ & $x$ & $x$ & $x$ & $\mathrm{x}$ & $x$ & $\mathrm{x}$ & $\mathrm{x}$ & $\mathrm{x}$ & $\mathrm{x}$ & $\mathrm{x}$ & $\mathrm{x}$ \\
\hline \multirow{2}{*}{\multicolumn{13}{|c|}{ Debt }} \\
\hline & & & & & & & & & & & & \\
\hline $\begin{array}{l}\text { Public sector } \\
\text { Private sector }\end{array}$ & & $x^{13}$ & x & $\mathrm{x}$ & & & & & $x$ & & & \\
\hline \multicolumn{12}{|l|}{$\begin{array}{l}\text { Private sector } \\
\text { Repayment of domestic }\end{array}$} & \\
\hline \multicolumn{13}{|l|}{$\begin{array}{l}\text { Restrictions on cligible } \\
\text { investments }\end{array}$} \\
\hline $\begin{array}{l}\text { Restrictions on capital } \\
\text { repatriations }\end{array}$ & $x$ & $x$ & $x$ & $\mathrm{x}$ & $\mathrm{x}$ & $\mathrm{x}$ & $x$ & & $\mathrm{x}$ & $\mathrm{x}$ & $\mathrm{x}$ & $\mathrm{x}$ \\
\hline \multicolumn{13}{|l|}{$\begin{array}{l}\text { Restrictions on profit } \\
\text { remittances }\end{array}$} \\
\hline $\begin{array}{l}\text { More restrictive than } \\
\text { the above }\end{array}$ & $\mathrm{x}$ & 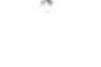 & $\mathrm{x}$ & $\mathrm{x}$ & $\mathrm{x}$ & $x$ & $\mathrm{x}$ & & & $\mathrm{x}$ & $\wedge$ & $x$ \\
\hline $\begin{array}{l}\text { Other features } \\
\text { Limit on value of } \\
\text { conversions }\end{array}$ & $x$ & & $\mathrm{x}$ & $x$ & $\mathrm{x}$ & $x^{14}$ & $x$ \\
\hline Auction system & $\hat{x}$ & $\hat{x}$ & $x^{15}$ & & & $\hat{x}$ & $\hat{x}$ & $\hat{x}$ & $\hat{x}$ & $\hat{x}$ & & $\hat{x}$ \\
\hline Conversion fees & & & & & & & $x^{10}$ & & $\mathrm{x}$ & & & \\
\hline $\begin{array}{l}\text { Additional foreign } \\
\text { exchange required }\end{array}$ & & & $x$ & & & & $x^{17}$ & & & & & \\
\hline 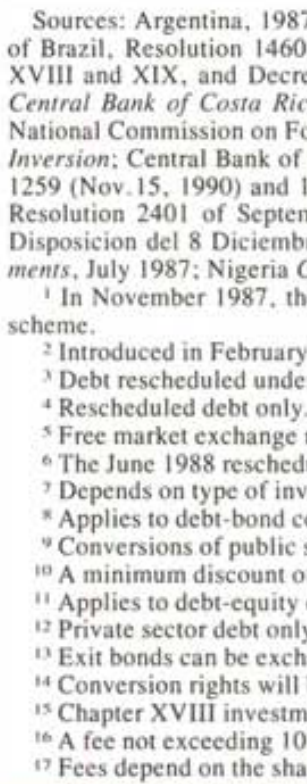 & $\begin{array}{l}\text { Refinancing } \\
\text { February 1. } \\
\text { Law } 600 \text {; } \\
\text { imto Colon } \\
\text { reign Investn } \\
\text { hilippines, } \\
18 \text { (Dec, } 27 \\
\text { ber } 4,1989 \\
\text { 1987: Ban } \\
\text { uidelines on } \\
\text { authorities } \\
1987 \text { and ten } \\
\text { the A tranch } \\
\text { te. } \\
\text { ling agreem } \\
\text { stment and } \\
\text { nversions. } \\
\text { ector debt ar } \\
35 \text { percent a } \\
\text { onversions. } \\
\text { nged for Tre } \\
\text { e administra } \\
\text { nts only. } \\
\text { oercent of th. } \\
\text { e of investm. }\end{array}$ & $\begin{array}{l}\text { Plan; B } \\
\text { 1988: } \\
\text { Central } \\
\text { nes: Cent } \\
\text { ment, Mo } \\
\text { Revised } \\
7 \text {. 1990). } \\
9 \text {; Centra } \\
\text { ik of Jam } \\
\text { Debt Co } \\
\text { announc } \\
\text { mporarily } \\
\text { he of the }\end{array}$ & $\begin{array}{l}\text { razil, } \\
\text { Centra } \\
\text { Bank } \\
\text { tral Ba } \\
\text { amual } \\
\text { Circul. } \\
\text { and C } \\
\text { al Bany } \\
\text { naica, } \\
\text { onversi } \\
\text { ced a n } \\
\text { y suspe } \\
\text { June I } \\
\text { ws for c } \\
\text { unt in s } \\
\text { to to a st }\end{array}$ & $\begin{array}{l}\text { Foreign } \\
\text { al Bank } \\
\text { of Cost } \\
\text { ank of } \\
\text { Operati } \\
\text { lar No. } \\
\text { Central } \\
\text { k of H } \\
\text { Progra } \\
\text { ion Pro } \\
\text { lew deb } \\
\text { ended in }\end{array}$ & $\begin{array}{l}\text { Investmer } \\
\text { of Chile, } \\
\text { ta Rica, A } \\
\text { Ecuador, } \\
\text { ivo para la } \\
\text { IIII: Ven } \\
\text { Bank Res } \\
\text { londuras C } \\
\text { amme for } t \\
\text { gram for } N \\
\text { bt-equity st } \\
\text { n August I }\end{array}$ & $\begin{array}{l}\text { nt Law (La) } \\
\text { Compendit } \\
\text { Guide for } \\
\text { Monetary B } \\
\text { Capitaliza } \\
\text { vezuela, Of } \\
\text { olution } 89- \\
\text { tircular D- } \\
\text { he Convers } \\
\text { igeria, July } \\
\text { wap schem } \\
987 . \\
\text { agreement } \\
\text { bonds and } \\
\text { nversion ter }\end{array}$ & $\begin{array}{l}\text { w No. } 4.1 \\
\text { um of } R u \\
\text { Convertin } \\
\text { Board Cir } \\
\text { cion de Pa } \\
\text { fice of the } \\
8-04 \text { of } A \\
036 / 89, \text { J } \\
\text { ion of Jan } \\
\text { y } 5,1988 \text {. } \\
\text { e. The de } \\
\text { with comt }\end{array}$ & $\begin{array}{l}131 \text { and } \\
\text { les on In } \\
\text { ng Foreis } \\
\text { cular No } \\
\text { asivos y } \\
\text { e Presider } \\
\text { uugust } 31 \\
\text { July } 6 \text {, I } \\
\text { maican E } \\
\text { and } 1988 \\
\text { escription }\end{array}$ & $\begin{array}{l}\text { Decree } \mathrm{Ne} \\
\text { ternation } \\
\text { gn Debt } \\
\text { s. 395-8 } \\
\text { Sustitucio } \\
\text { nt of the } \\
\text { 1989, a } \\
989 ; \text { Cen } \\
\text { Eternal } \\
\text { Resched } \\
\text { in this t: }\end{array}$ & $\begin{array}{l}55.76 \\
\text { al Exch } \\
\text { Securitie } \\
6 \text { and } 4 t \\
n \text { de Det } \\
\text { Republic } \\
\text { ind Mini } \\
\text { ttral Bat } \\
\text { Debt inte } \\
\text { leling Pr } \\
\text { able corn }\end{array}$ & $\begin{array}{l}\text { 2) Central } \\
\text { tange, Ch: } \\
\text { es Issued } \\
\text { 08-87: M } \\
\text { uda Public } \\
\text { c, Decrees } \\
\text { istry of Fi } \\
\text { nk of Uru } \\
\text { of Equity I } \\
\text { roposal. } \\
\text { responds t }\end{array}$ & $\begin{array}{l}\text { Bank } \\
\text { apters } \\
\text { by the } \\
\text { exico, } \\
\text { ca por } \\
\text { s Nos. } \\
\text { inance } \\
\text { uguay, } \\
\text { invest- } \\
\text { to this }\end{array}$ \\
\hline
\end{tabular}




\section{References}

Basle Committee on Banking Supervision (1990a), "Measuring and Controlling Large Credit Exposure," paper circulated at Sixth International Conference of Banking Supervisors, Frankfurt, October 1990.

- (1990b), Report on International Developments in Banking Supervision, Report No. 7 (Basle, September 1990).

Bernanke, B.S., "Irreversibility, Uncertainty, and Cyclical Investment," Quarterly Journal of Economics (Cambridge, Massachusetts), Vol. 98 (February 1983), pp. 85-106.

$\longrightarrow$, and M. Gertler, "Financial Fragility and Economic Performance," Quarterly Journal of Economics (Cambridge, Massachusetts), Vol. 105 (February 1990), pp. $87-114$.

Bhattacharya, S., and D. Gale, "Preference Shocks, Liquidity, and Central Bank Policy," in New Approaches to Monetary Economics, ed. by W.A. Barnett and K.J. Singleton (Cambridge, Massachusetts: Cambridge University Press, 1987), pp. 69-88.

Board of Governors of the Federal Reserve System, The Federal Reserve System: Purposes and Functions (Washington: Board of Governors of the Federal Reserve System, 1984).

Boehmer, Ekkehart, and William Megginson, "Determinants of Secondary Market Prices for Developing Country Syndicated Loans," Journal of Finance (New York), Vol. 45 (December 1990), pp. 1517-40.

Chari, V.V., and R. Jagannathan, "Banking Panics, Information, and Rational Expectations Equilibrium," Journal of Finance (New York), Vol. 43 (July 1988), pp. 749-61.

Corrigan, Gerald E., "Reforming the U.S. Financial System: An International Perspective," Quarterly Review, Federal Reserve Bank of New York (New York), Vol. 15 (Spring 1990), pp. 1-14.

Cukierman, A.. "The Effects of Uncertainty on Investment Under Risk Neutrality with Endogenous Information," Journal of Political Economy (Chicago), Vol. 87 (June 1980), pp. 462-75.

Davis, E.P., "Instability in the Euromarkets and the Economic Theory of Financial Crisis," Bank of England Discussion Paper, No. 43 (October 1989).

Eichengreen, Barry, and Peter H. Lindert, eds., The International Debt Crisis in Historical Perspective (Cambridge, Massachusetts: MIT Press, 1989).

Federal Deposit Insurance Corporation, Federal Deposit Insurance Corporation: The First Fifty Years (Washington. 1984), pp. 53-79.

—. "Failure Resolution," Chapter 7 in "Deposit Insurance for the Nineties: Meeting the Challenge" (mimeographed, Washington, January 4, 1989).

Financial System Research Council, "On a New Japanese Financial System" (Tokyo, July 13, 1990).
Folkerts-Landau, D. "The Changing Role of International Bank Lending in Development Finance," Staff Papers International Monetary Fund (Washington), Vol.32 (June 1985), pp. 317-63.

(1990a), “The Case for International Coordination of Financial Policy," in International Policy Coordination and Exchange Rate Fluctuations, ed. by W.N. Branson, J.A. Frenkel, and M. Goldstein (Chicago: University of Chicago Press, 1990).

(1990b), "Systemic Financial Risk in Payment Systems," IMF Working Paper No. WP/90/65 (unpublished. Washington: International Monetary Fund, July 1990).

Frenkel, Jacob A., and others, eds., Analytical Issues in Debt (Washington: International Monetary Fund, 1989).

Fries, S.M., "Issues in Deposit Insurance Reform and Regulation of Depository Institutions," IMF Working Paper No. WP/90/74 (unpublished, Washington: International Monetary Fund, August 1990).

Froot, Kenneth, and Paul Krugman, "Market-Based Debt Reduction for Developing Countries: Principles and Prospects" (unpublished, Washington, 1990)

Fundamental Research Committee of the Securities and Exchange Council, "Restructuring Japan's Capital Market: Toward an International Market" (Tokyo, June 15. 1990).

Furlong, F. T., and M.C. Keeley, "Capital Regulation and Risk Taking: A Note," Journal of Banking and Finance (Amsterdam), Vol. 13 (December 1989), pp. 883-91.

Goodfriend, M., and R.G. King, "Financial Deregulation, Monetary Policy, and Central Banking," in Restructuring Banking and Financial Services in America, ed. by W.S. Haraf and R.M. Kushmeider (Washington: American Enterprise Institute, 1988), pp. 216-53.

Goodhart, C.A.E., "Why Do Banks Need a Central Bank?" Oxford Economic Papers (London), Vol. 39 (March 1987), pp. 75-89.

Gorton, G., "Bank Suspension of Convertibility," Journal of Monetary Economics (Amsterdam), Vol. 15 (March 1985), pp. 177-93.

- "Banking Panics and Business Cycles," Oxford Economic Papers (London), Vol. 40 (December 1988), pp. 751-81.

Greenspan, Alan, "Statement by Allen Greenspan, Chairman, Board of Governors of the Federal Reserve System," Federal Reserve Bulletin (Washington), Vol. 76 (November 1990), pp. 917-27.

Heller, Robert, "Preventing Future Stock Market Collapses," remarks delivered at the Commonwealth Club of California in San Francisco on October 27, 1989.

International Monetary Fund, Determinants and Systemic Consequences of International Capital Flows. Occasional Paper No. 77 (Washington, 1991). 
- International Capital Markets: Developments and Prospects, World Economic and Financial Surveys (Washington, 19_-).

World Economic Outlook: A Survey by the Staff of the International Monetary Fund, World Economic and Financial Surveys (Washington, 19_).

International Organization of Securities Commission (IOSCO). "Capital Requirements for Multinational Securities" (Santiago, November 1990).

Jacklin, C.J., and S. Bhattacharya, "Distinguishing Panics and Information-Based Bank Runs: Welfare and Policy Implications," Journal of Political Economy (Chicago), Vol. 96 (June 1988) pp. 568-92.

Johnson, G.G., Mathew Fisher, and Elliott Harris, Offcially Supported Export Credits: Developments and Prospects, World Economic and Financial Surveys (Washington: International Monetary Fund, May 1990).

Kaufman, G.G., "Bank Runs: Causes, Benefits, and Costs," Cato Journal (Washington, D.C.), Vol. 7 (Winter 1988), pp. 559-87.

Keeley, M.C., "Deposit Insurance, Risk, and Market Power in Banking," American Economic Review (Nashville), Vol. 80 (December 1990), pp. 1183-1200.

Kindleberger, C.P., Manias, Panics, and Crashes: A History of Financial Crises (New York: Basic Books, 1978).

Mathieson, Donald J., and D. Folkerts-Landau, "Innovation, Institutional Changes, and Regulatory Response in International Financial Markets," in Restructuring Banking and Financial Services in America, ed. by W.S. Haraf and R.M. Kushmeider (Washington: American Enterprise Institute, 1988) pp. 392-423.

Romer, C.D., "The Great Crash and the Onset of the Great
Depression," Quarterly Journal of Economics (Cambridge, Massachusetts), Vol. 105 (August 1990), pp. 597-624.

Saunders, A., "The Inter-Bank Market, Contagion Effects and International Financial Crises," in Threats to International Financial Stability, ed. by R. Portes and A.K. Swoboda (Cambridge: Cambridge University Press, 1987), pp. 196-232.

Schwartz, A.J., "Financial Stability and the Federal Safety Net," in Restructuring Banking and Financial Services in America, ed. by W.S. Haraf and R.M. Kushmeider (Washington: American Enterprise Institute, 1988), pp. 34-62.

Solow, R.M., "On the Lender of Last Resort," in Financial Crises: Theory, History, and Policy, ed. by C.P. Kindleberger and J.-P. Laffargue (Cambridge: Cambridge University Press, 1982), pp. 237-48.

Stone, Mark, "Are Sovereign Debt Secondary Market Returns Sensitive to Macroeconomic Fundamentals? Evidence from the Contemporary and Interwar Markets," IMF Working Paper No. WP/90/69 (unpublished, Washington: International Monetary Fund, 1990).

Timberlake, R.H., "The Central Banking Role of Clearing House Associations," Journal of Money, Credit and Banking (Columbus), Vol. 41 (February 1984), pp. 1-15.

United States, Congress, Budget Office, Reforming Federal Deposit Insurance, Appendix B (Washington: Government Printing Office, September 1990).

World Institute for Development Economic Research (WIDER), Foreign Portfolio Investment in Emerging Equity Markets, Study Group Series, No. 5 (Helsinki, March 1990). 
January 1988

February 1988

April 1988

May 1988

May 1988

July 1988

October 1988

April 1989

April 1989

July 1989

August 1989

September 1989

October 1989

April 1990

May 1990

May 1990

July 1990

September 1990

October 1990

November 1990

May 1991
International Capital Markets: Developments and Prospects, by Maxwell Watson, Donald Mathieson, Russell Kincaid, David Folkerts-Landau, Klaus Regling, and Caroline Atkinson.

Officially Supported Export Credits: Developments and Prospects, by K. Burke Dillon and Luis Duran-Downing, with Miranda Xafa.

World Economic Outlook: A Survey by the Staff of the International Monetary Fund.

Multilateral Official Debt Rescheduling: Recent Experience, by Peter M. Keller, with Nissanke E. Weerasinghe.

Primary Commodities: Market Developments and Outlook, by the Commodities Division of the Research Department.

Staff Studies for the World Economic Outlook, by the Research Department of the International Monetary Fund.

World Economic Outlook: Revised Projections, by the Staff of the International Monetary Fund.

World Economic Outlook: A Survey by the Staff of the International Monetary Fund.

International Capital Markets: Developments and Prospects, by a Staff Team from the Exchange and Trade Relations and Research Departments.

Primary Commodities: Market Developments and Outlook, by the Commodities Division of the Research Department.

Staff Studies for the World Economic Outlook, by the Research Department of the International Monetary Fund.

Developments in International Exchange and Trade Systems, by a Staff Team from the Exchange and Trade Relations Department.

World Economic Outlook: A Survey by the Staff of the International Monetary Fund.

International Capital Markets: Developments and Prospects, by a Staff Team from the Exchange and Trade Relations and Research Departments.

Officially Supported Export Credits: Developments and Prospects, by G.G. Johnson, Matthew Fisher, and Elliott Harris.

World Economic Outlook: A Survey by the Staff of the International Monetary Fund.

Primary Commodities: Market Developments and Outlook, by the Commodities Division of the Research Department.

Staff Studies for the World Economic Outlook, by the Research Department of the International Monetary Fund.

World Economic Outlook: A Survey by the Staff of the International Monetary Fund.

Multilateral Official Debt Rescheduling: Recent Experience, by Michael G. Kuhn with Jorge P. Guzman.

International Capital Markets: Developments and Prospects, by a Staff Team from the Exchange and Trade Relations and Research Departments. 
